\title{
Aspectos epidemiológicos da hepatite $B$ e fatores prognósticos da cirrose em pacientes com hepatite B crônica na Amazônia Ocidental
}

Cirley Maria de Oliveira Lobato

Tese apresentada ao Programa de PósGraduação em Saúde Pública da Faculdade de Saúde Pública da Universidade de São Paulo para obtenção do título de Doutor em Saúde Pública.

Área de Concentração: Epidemiologia

Orientador: Prof. Dr. Eliseu Alves Waldman

São Paulo

2011

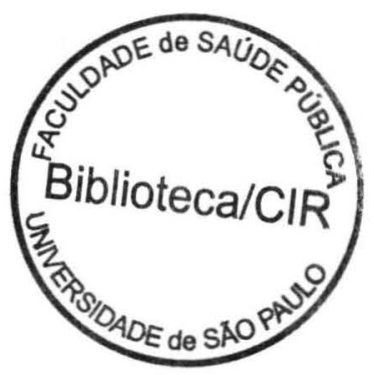




$$
5313512011
$$

E expressamente proibida a comercialização deste documento, tanto na sua forma impressa como eletrônica. Sua reprodução total ou parcial é permitida exclusivamente para fins acadêmicos e científicos, desde que na reprodução figure a identificação do autor, titulo: Aspectos epidemiológicos da hepatite B e fatores prognósticos da cirrose em pacientes com hepatite B crônica na Amazônia Ocidental, Faculdade de Saúde Pública,USP, 2011. 
Dedico este estudo, em primeiro lugar a quem me ajudou em todos os momentos,

Ao Deus Pai, o Grande Eu Sou

Ao Deus Filho, Jesus Cristo

Ao Deus Espírito Santo, o Grande Consolador

Dedico também, juntamente com este versículo bíblico, que me deu esperança, me fortaleceu e me ajudou a seguir em frente;

Às minhas filhas Geórgia Helena e Julie Beatriz

"Não temas, porque Eu sou contigo; não te assombres, porque Eu sou teu Deus; Eu te fortaleço e te ajudo, e te sustento com a destra da minha justiça. Eis, que envergonhados e confundidos serão todos os que se indignaram contra ti; tornar-se-ão em nada, e os que contenderem contigo, perecerão.

Buscá-los-ás, porém não os acharás; os que pelejarem contigo, tornar-se-ão em nada, e como coisa que não é nada, os que guerrearem contigo.

Porque Eu, o Senhor teu Deus, te tomo pela tua mão direita, e te digo: Não temas, Eu te ajudo.

Não temas, tu verme de Jacó, povozinho de Israel; Eu te ajudo, diz o Senhor, e o teu redentor é o Santo de Israel.

Quando passares pelas águas, estarei contigo e quando pelos rios, eles não te submergirão; quando passares pelo fogo, não te queimarás, nem a chama arderá em ti. Porque Eu sou o Senhor teu Deus, o Santo de Israel, o teu Salvador".

Isaias $41: 10-13$ e $43: 2-3$

$E$,

Aos meus pais Francisco Maria da Silva Lobato e Maura de Oliveira Lobato (Póstuma) que em vida me ensinaram a lutar por um objetivo e antes de partirem, me incentivaram a não desistir. 


\section{AGRADECIMENTOS}

Ao Pai, ao Filho e ao Espírito Santo, que sempre nos momentos de angústia, de dúvidas, de saudades, na sua Palavra encontrava força e a certeza para prosseguir.

Ao Prof. Dr. Eliseu Alves Waldman meu orientador, que ousou acreditar na realização deste estudo e a trabalhar com novas idéias e conceitos, correndo os riscos inerentes a esta atitude. Meus sinceros agradecimentos, pois com seu profundo conhecimento científico contribuiu e me estimulou a ver os fatos com olhar em epidemiologia e Saúde Pública.

Ao Prof. Dr. Raymundo Paraná, que sempre me incentivou a dar mais um passo, deu-me oportunidade de crescimento no aprendizado sobre hepatites, pelas valiosas sugestões e críticas oferecidas durante o meu trabalho.

Ao Prof. Dr. Eduardo Martins Netto, que foi fundamental nas ultimas análises, me ensinou a perder o medo do SPSS (Ufaaa!!!!!)

A Profa. Dra. Maria Isabel Schinoni que sempre foi um canal para fazer as coisas aconteceram e deu sugestões preciosas na reta final deste estudo

Ao Prof. Dr. Pascoal Muniz e Prof ${ }^{a}$. Dra. Raimunda Araruna, pelas palavras de incentivo e conforto.

Ao Prof. Dr. Sebastião Afonso Viana Neves, que sempre sonhou e na realização de seus sonhos, realizou o sonhos de muitos acrianos.

Aos colegas de trabalho do Serviço de Assistência Especializada, na pessoa do Augusto, Enf. Edna Gonçalves, Ana Gurgel, Ir. Ana Moura, Ir. Raimunda, Dany, e todo o grupo do SAME pela colaboração, apoio, amizade e paciência que tiveram comigo durante o levantamento dos dados nos prontuários dos pacientes.

A Dra. Janaina Mazaro, ao Antonio Hipólito que sempre foram solicitos, quando precisava de alguma informação no LACEN.

À Monica Abreu, que pelo seu entusiasmo e persistência fez a diferença na luta pelos portadores de hepatite do Estado do Acre.

Ao meu amigo Silvio Ferreira, sua esposa Janice e filhos que sempre estiveram presente, nos momentos aqui em São Paulo, longe de minhas filhas. 
Aos meus irmãos na fé, do Ministério Madureira, na pessoa do Pastor Waldemar e Pastor Sebastião e irmãos da Congregação Vitória I, que me sustentaram em oração.

Ao Presbítero Hercules, sua esposa Missionária Ofanir, e a Diaconisa Estefânia Pontes, que se empenharam para ficar e cuidar de minhas filhas, em uma das minhas ausências.

Ao Diácono José Lopes e sua esposa Missionária Ellen Cristina (carinhosamente Tina), pelo apoio, pelas longas madrugadas em vigília intercedendo por mim, pelo cuidar das minhas filhas na conclusão deste trabalho. Somente Deus poderá recompensá-los

À Almira, minha secretária, que não mediu esforços para ajudar no cuidar da Geórgia Helena e Julie Beatriz, nas minhas viagens para São Paulo.

À Dona Raimunda Alencar e família que me acolheram, ajudaram nos momentos finais deste trabalho.

Aos colegas da Universidade Federal do Acre, Nailton, Thiago, Suleima, Raquel, que sempre estiveram dispostos a me ajudar diante de duvidas relacionado à estatística.

Aos pacientes que decidiram participar deste estudo, o qual sem a colaboração deles, não seria possivel realizá-lo.

Às pessoas que tiveram papel fundamental para que o convênio USP/UFAC se realizasse, dando possibilidade de realizar o DINTER, em especial à Prof ${ }^{a}$ Dra. Neia Schor, Prof.Dr. Delsio Natal.

A Prof ${ }^{a}$ Ducélia Mota Lopes, que com carinho e seu toque especial fez com que o texto ficasse aprazivel à leitura.

A todos que de forma direta ou indireta contribuíram para a realização deste trabalho, ou dando sugestão, ou criticando, ou simplesmente torcendo para que tudo desse certo.

Aos meus irmãos Carlos, Cristina, Celiney, Celso, Cezar e Cinthia que mesmo distante fisicamente, sempre tinham uma palavra amiga, um gesto de ternura, uma mensagem.... Amo a todos e quantas saudades!!!!!

Às minhas filhas Geórgia Helena e Julie Beatriz, que com todo amor, compreenderam os muitos nãos, as ausências e, podemos juntas agradecer a Deus e dizer VENCEMOS.

Que toda Honra e toda Glória sejam dadas a Deus. 


\section{RESUMO}

Introdução: Vários fatores têm sido apontados como associados à progressão da hepatite $B$ crônica para cirrose, entre eles o genótipo, mutações do VHB, status do $\mathrm{HBeAg}$, infecção concorrentes com o VHD, HIV, VHC, assim como o uso de álcool, alterações metabólicas e idade em que ocorreu a infecção. No entanto, essa questão ainda não foi estudada na Amazônia Ocidental brasileira, área hiperendêmica de hepatite B. Objetivo: descrever os aspectos clínico-epidemiológicos e investigar fatores associados à progressão da cirrose numa coorte de pacientes com hepatite crônica pelo vírus $B$ residente no estado do Acre, atendidos em serviço especializado entre 2000 e 2009. Métodos: estudo de coorte retrospectiva, abrangendo 672 pacientes com hepatite crônica pelo vírus $B$ matriculados no Serviço de Assistência Especializada, Rio Branco, Acre, na Amazônia Ocidental, selecionados no periodo de 2000 a 2009 e acompanhados até 2010. Os dados foram obtidos mediante consulta a prontuários, complementados por entrevista, exames físicos e laboratoriais. Os casos de cirrose hepática foram confirmados pela presença de fibrose, formação de nódulos parenquimatosos regenerados ou em regeneração ao exame anatomopatológico (F3 e F4) e/ou pela presença de sinais de descompensação hepática ou de hipertensão portal demonstrada através da ultrassonografia abdominal e endoscopia. Foram excluídos do estudo os pacientes que apresentaram hepatocarcinoma, coinfecção com o HIV no momento da primeira avaliação. As variáveis de interesse foram: sóciodemográficas; características relativas à transmissão, aspectos clínicos e laboratoriais. Inicialmente, descreveram-se as características dos pacientes mediante comparações de proporções e médias aplicando-se para variáveis categóricas o teste do qui quadrado e exato de Fisher; e para as variáveis contínuas o teste de Kruskall-Walis. Para a investigação dos fatores, associados à evolução para cirrose, a variável dependente foi a cirrose hepática e as independentes as exposições de interesse, estimaram-se as 
odds ratio não ajustadas e ajustadas e os respectivos intervalos de $95 \%$ de confiança ( $\left(\mathrm{CC}_{95 \%}\right)$ pela regressão logística condicional. Resultados: O tempo médio de acompanhamento foi de 52,7 $\pm 12,8$ meses; $8,5 \%$ (57/672) dos pacientes evoluíram para cirrose, com uma taxa de incidência de 26,8/1000 pessoa ano. Mostraram-se independentemente associados à evolução para cirrose: pertencer ao sexo masculino (OR=2,2; IC95\%: 1,1 - 3,7); coinfecção com VHC (OR= 4,6; IC95\%: 1,2-17,8); co-infecção pelo VHD na presença de $\mathrm{HBeAg}(\mathrm{OR}=4,0$; IC95\%:1,3-11,9); co-infecção pelo VHD na presença de Anti $\mathrm{HBe}(\mathrm{OR}=7,1 ; \mathrm{IC} 95 \%: 1,2-17,8)$, presença de gama GT $>2$ LSN (OR = 2,7; IC95\%:1,3-5,4). Conclusão. O presente estudo apontou o risco elevado de progressão da hepatite $B$ crônica para cirrose, identificou marcadores laboratoriais prognósticos de evolução para cirrose, assim como seus principais preditores na área de estudo, salientando a importância de políticas públicas com foco no controle dessa infecção, assim como de condutas clínicas voltadas ao monitoramento de complicações das formas crônicas relacionadas à co-infecção com VHC e VHD.

Palavras chave: Hepatite B crônica; cirrose, fatores de progressão, hepatite Delta, Amazônia ocidental. 


\section{ABSTRACT}

Introduction: Progression to cirrhosis in chronic hepatitis B patients has been associated with several factors including HBV genotype and mutations, $\mathrm{HBeAg}$ status, concurrent HDV, HIV and HCV infection, alcohol use, metabolic disorders and age at HBV infection. This health condition has not yet been investigated in the western Brazilian Amazon, a hyperendemic area for hepatitis B. Objectives: To describe clinical and epidemiological characteristics and to assess factors associated with progression to cirrhosis in a cohort of chronic hepatitis B patients. Methods: A retrospective cohort study was conducted involving 672 chronic hepatitis $B$ patients attending a specialized care center in the city of Rio Branco, state of Acre, western Brazilian Amazon. All patients were selected between 2000 and 2009 and followed up until 2010. Data were obtained from medical records and collected through interviews, physical examinations and laboratory tests. Liver cirrhosis was pathologically confirmed by the presence of fibrosis and regenerative or regenerating parenchymal nodules (F3 and F4) and/or clinically by signs of liver decompensation or portal hypertension seen in abdominal ultrasound and endoscopy. Patients with hepatocarcinoma and HIV coinfection in the screening evaluation were excluded from the study. The study variables included sociodemographic, disease transmission and clinical and laboratory characteristics. Patient characteristics were described using proportions and means and the chi-square test and Fisher's exact test were performed for categorical variables and the Kruskall-Wallis was performed for continuous variables. For the assessment of factors associated with progression to cirrhosis the dependent variable was liver cirrhosis and the independent variables were the exposures of interest. Crude and adjusted odds ratios and their related $95 \%$ confidence intervals $(95 \% \mathrm{Cl})$ were estimated using conditional logistic regression. Results: The mean follow-up was $52.7 \pm 12.8$ months; $8.5 \%(57 / 672)$ of patients progressed to cirrhosis with an incidence rate of 26.8 per 1,000 person-years. The following factors were independently associated with progression to cirrhosis: male sex (OR=2.2, 95\% Cl: 1.1-3.7); HCV coinfection (OR=4.6, 95\% Cl: 1.2-17.8); 
HDV coinfection and $\mathrm{HBeAg}$ positive (OR=4.0, 95\% Cl: 1.3-11.9); HDV coinfection and anti-HBe positive (OR=7.1, 95\% Cl: $1.2-17.8)$; and gamma GT >2 ULN (OR=2.7, 95\% Cl: 1.3-5.4). Conclusions: The present study found a high risk of progression to cirrhosis in chronic hepatitis $B$ patients and identified prognostic laboratory markers of progression to cirrhosis as well as its main predictors in the study area. There is a need for public policies focused on HBV infection control, as well as clinical actions for monitoring complications in chronic HCV patients coinfected with $\mathrm{HCV}$ and HDV.

Words key: Chronic hepatitis B; cirrhosis, progression of factors, Delta hepatitis, western Brazilian Amazon. 


\section{ÍNDICE}

1 INTRODUÇÃO

1.1 ASPECTOS CLÍNICOS 21

1.2 IMUNOPATOGÊNIA 24

1.3 CARACTERISTICA DO AGENTE (VHB) 26

1.4 EPIDEMIOLOGIA 30

1.5 FATORES DE RISCO PARA AS FORMAS GRAVES 32

1.6 DIAGNÓSTICO DA INFECÇÃO PELO VHB 39

1.7 TRATAMENTO DA HEPATITE B CRÔNICA 41

1.8 IMUNOPROFILAXIA DA HEPATITE B 43

1.9 CARACTERÍSTICAS DA INFECÇÃO PELO VHB NO BRASIL 44

1.10 VÍRUS DA HEPATITE DELTA 50

1.11 HISTÓRIA DO ACRE: Um elo para entender as características da 55 infecção pelo vírus da hepatite $B$ e delta no estado

2 HIPÓTESE $\quad 61$

3 OBJETIVOS $\quad 62$

4 MATERIAL E MÉTODO 63

4.1 TIPO DE ESTUDO 63

4.2 ÁREA DE ESTUdO 63

4.3 LOCAL DO ESTUDO 65

4.4 POPULAÇÃO DO ESTUDO 66

4.5 CONCEITOS E DEFINIÇÕES 66

4.5.1 Definição de caso no estudo 66

$\begin{array}{ll}\text { 4.5.2 Conceitos } & 67\end{array}$

$\begin{array}{ll}\text { 4.5.2.1 Infecção pelo VHB } & 67\end{array}$ 
4.5.2.2 Infecção crônica pelo VHB

$\begin{array}{ll}\text { 4.5.2.3 Imunotolerância ao VHB } & 67\end{array}$

$\begin{array}{ll}\text { 4.5.2.4 Portador inativo do VHB } & 67\end{array}$

$\begin{array}{ll}\text { 4.5.2.5 Hepatite crônica pelo VHB } & 67\end{array}$

4.5.2.6 Cirrose hepática 68

4.5.2.7 Tratamento da hepatite B crônica 68

4.5.3 Técnicas Laboratoriais $\quad 69$

$\begin{array}{ll}\text { 4.5.3.1 Testes bioquímicos } & 69\end{array}$

$\begin{array}{ll}\text { 4.5.3.2 Testes imunológicos e moleculares } & 70\end{array}$

$\begin{array}{ll}\text { 4.5.3.3 Análise histológica } & 70\end{array}$

4.6 CRITÉRIOS DE INCLUSÃO

4.7 CRITÉRIOS DE EXCLUSÃO

$\begin{array}{ll}\text { 4.8 FONTE DE DADOS } & 71\end{array}$

4.9 PROCEDIMENTO DE SELEÇÃO DA POPULAÇÃO DO ESTUDO 72

4.10 VARIÁVEIS DO ESTUDO

4.11 CRIAÇÃO DO BANCO DE DADOS 73

4.12 ANÁLISE DOS DADOS 73

4.13 CONSIDERAÇÕES ÉTICAS $\quad 74$

5 RESULTADOS

5.1 FORMAÇÃO DA COORTE ESTUDADA 76

5.2 RESULTADO DA COORTE DE PORTADORES DO VHB 77

5.2.1 Descrição das características dos indivíduos portadores $\quad 77$ crônicos do VHB sem cirrose à entrada do estudo

5.2.2 Descrição das características dos indivíduos portadores 82 crônicos do VHB sem cirrose à entrada do estudo, segundo história de tratamento 
5.2.3 Descrição das características dos indivíduos portadores crônico do VHB sem cirrose à entrada do estudo, mono infectado ou com dupla infecção com o VHD

5.2.4 Descrição das características dos indivíduos portadores

crônicos do VHB, que evoluíram para cirrose durante o acompanhamento

5.2.4.1 Incidência de cirrose

5.2.4.2 Análise bivariada

5.2.4.3 Análise multivariada

5.2.5 Descrição das características dos indivíduos portadores crônicos do VHB, que evoluíram para cirrose segundo história de tratamento

5.2.6 Descrição das características dos indivíduos portadores crônicos do VHB, sem cirrose à entrada do estudo, que evoluíram para carcinoma hepatocelular

6 DISCUSSÃO

106

7 CONCLUSÕES

120

8 REFERÊNCIAS BIBLIOGRAFICAS

122

\section{APÊNDICES E ANEXOS}

Apêndice 1. Termo de Responsabilidade

Apêndice 2. Questionário

Apêndice 3. Características sociodemográficas, na avaliação inicial, 149 dos pacientes com infecção crônica pelo vírus da hepatite $B$ atendidos no Serviço de Assistência Especializada*, 2000 a 2009. Rio Branco, Acre, Brasil.

Apêndice 4. Características sociodemográficas, na avaliação inicial dos pacientes com infecção crônica pelo vírus da hepatite $B$ atendidos no Serviço de Assistência Especializada*, 2000 a 2009. Rio Branco, Acre, Brasil.

Apêndice 5. Características epidemiológicas dos pacientes com infecção pelo vírus da hepatite $B$ atendidos no Serviço de Assistência Especializada*. 2000 a 2009. Rio Branco, Acre, Brasil.

Apêndice 6. Características epidemiológicas dos pacientes com infecção pelo virus da hepatite B atendidos no Serviço de Assistência 
Especializada*. 2000 a 2009. Rio Branco, Acre, Brasil.

Apêndice 7 Características epidemiológicas dos pacientes com 153 infecção pelo vírus da hepatite $B$ atendidos no Serviço de Assistência Especializada*. 2000 a 2009. Rio Branco, Acre, Brasil

Apêndice 8. Historia de ingestão de álcool dos pacientes com infecção pelo vírus da hepatite $B$ atendidos no Serviço de Assistência Especializada*. 2000 a 2009. Rio Branco, Acre, Brasil.

Anexo 1. Glossário de termos técnicos usados na infecção pelo VHB. 155

Anexo 2. Critérios diagnósticos para o VHB 155

Anexo 3. Perfil sorológico da coinfecção aguda pelos VHB e VHD 155

Anexo 4. Perfil sorológico da superinfecção aguda pelo VHD em 156 diferentes padrões sorológicos de portadores do VHB

Anexo 5. Sistema de graduação de atividade necroinflamatória, fibrose e cirrose

Anexo 6. Critérios diagnósticos para $\mathrm{HCC}$ - Associação Européia para Estudo de Doença do Fígado-ASLD

Anexo 7. População Residente por Faixa Etária e Ano, período: 2000 2009

Anexo 8. Valores de referencia dos exames bioquímicos realizados no Laboratório Central de Saúde Pública - AC até 2007

Anexo 9. Valores de referencia dos exames bioquímicos realizados no Laboratório Central de Saúde Pública - AC em 2008 e 2009.

Anexo 10. Valores de referencia dos exames bioquímicos realizados no Laboratório Central de Saúde Pública - AC a partir 2010.

Anexo 11. Algoritmos de tratamento da hepatite $B$ cronica segundo Protocolo Clinico e Diretrizes Terapêuticas para o tratamento da Hepatite Viral Crônica B e Co-infecções, MS (2010).

Anexo 12. Parecer do Comitê de Ética em Pesquisa - COEP/FSP

Anexo 13. Parecer do Comitê de Ética em Pesquisa - FUNDHACRE

Anexo 14. Currículo Lattes 


\section{LISTA DE SIGLAS E ABREVIATURAS}

VHB

HBsAg

Anti-HBctotal

VHC

HIV

AST

ALT

GGT

HBeAg

Anti-HBe

Anti-HBs

VHD

VHB-DNA

VHD-RNA

PCR

HVB

HDAg

AntiHDIgM

AntiHDIgG

AntiVHC

HCC

AFP

LACEN

SAE

HBC

HDC

HC
Virus da hepatite $B$

Antigeno de superficie do virus da hepatite $B$

Anticorpo IgG do antígeno Core do VHB

Virus da hepatite $C$

Virus da sindrome de imunodeficiência adquirida

Aspartatoaminotransferase

Alalinoaminotransferase

Gama glutamil-transpeptidase

Antigeno e do vírus da hepatite $B$

Anticorpo do antígeno $e$

Anticorpo do antígeno de superficie

Virus da hepatite delta

DNA do virus da hepatite $B$

RNA do vírus da hepatite delta

Reação em cadeia de polimerase

Hepatite pelo virus $B$

Antígeno do virus delta

Anticorpo IgM do antígeno do virus delta

Anticorpo $\lg G$ do antígeno do vírus delta

Anticorpo do virus da hepatite $C$

Carcinoma hepatocelular

Alfafetoproteina

Laboratório central

Serviço de Assistência Especializada

Hepatite B crônica

Hepatite delta crônica

Hepatite crônica 


\section{LISTA DE TABELAS}

Tabela 1 Equivalência aproximada das classificações mais usadas no estadiamento das hepatites crônicas

Tabela 2 Taxa de mortalidade por hepatite viral no Brasil e no Acre de 2003 a 2005

Tabela 3 Características dos pacientes portadores crônicos do vírus da hepatite $B$, selecionados para o estudo que cumpriam ou não os critérios estabelecidos por esta pesquisa, cadastrados no serviço de Assistência Especializada de 2000 a 2009, Rio Branco, Acre.

Tabela 4 Características sociodemográficas dos portadores crônico do vírus da hepatite $B$, segundo história de tratamento. Serviço de Assistência Especializada*. 2000 a 2010. Rio Branco, Acre, Brasil.

Tabela 5 Caracteristicas virais e da evolução clinica dos portadores crônicos do vírus da hepatite $B$, segundo história de tratamento. Serviço de Assistência Especializada*. 2000 a 2010. Rio Branco, Acre, Brasil.

Tabela 6 Características bioquímicas no início do seguimento, segundo história de tratamento, dos portadores crônicos do vírus da hepatite B. Serviço de Assistência Especializada, 2000 a 2010. Rio Branco, Acre, Brasil.

Tabela 7 Características dos portadores crônico do vírus da hepatite $\mathrm{B}$ com infeç̧ão associada ou não ao VHD, segundo aspectos sorológicos, histopatológico e clínico. Serviço de Assistência Especializada*. 2000 a 2009. Rio Branco, Acre, Brasil.

Tabela 8 Características dos portadores crônico do vírus da hepatite $B$ com infecção associada ou não ao VHD, segundo aspectos bioquímicos e ultrassonográfico iniciais. Serviço de Assistência Especializada*. 2000 a 2009. Rio Branco, Acre, Brasil.

Tabela 9 Características dos portadores crônico do vírus da hepatite B com infecção associada ou não ao VHD, segundo aspectos bioquímicos e ultrassonográfico no final do seguimento. Serviço de Assistência Especializada*. 2000 a 2009. Rio Branco, Acre, Brasil.

Tabela 10 Distribuição dos casos de infecção crônica pelo VHB, pessoaano e taxa de incidência de cirrose de 2000 a 2009, Rio Branco, Acre, Brasil. 
Tabela 11 Analise bivariada dos fatores associados à evolução para cirrose em portadores crônico do vírus da hepatite $B$ acompanhados no Serviço de Assistência Especializada*. 2000 a 2010. Rio Branco, Acre, Brasil.

Tabela 12 Analise bivariada relativa aos exames sorológicos e histopatológicos associados à evolução para cirrose em portadores crônico do vírus da hepatite B. Serviço de Assistência Especializada*. 2000 a 2010. Rio Branco, Acre, Brasil

Tabela 13 Analise bivariada relativa aos marcadores bioquímicos iniciais associados à evolução para cirrose em portadores crônico do vírus da hepatite B. Serviço de Assistência Especializada*. 2000 a 2010. Rio Branco, Acre, Brasil.

Tabela 14 Análise bivariada relativa aos marcadores bioquímicos durante o acompanhamento, associados à evolução para cirrose em portadores crônico do vírus da hepatite B. Serviço de Assistência Especializada*. 2000 a 2010. Rio Branco, Acre, Brasil.

Tabela 15 Análise bivariada relativa aos exames ultrassonográficos iniciais e durante o acompanhamento, associados à evolução para cirrose em portadores crônico do vírus da hepatite B. Serviço de Assistência Especializada*. 2000 a 2010. Rio Branco, Acre, Brasil.

Tabela 16 Modelo final da análise multivariada para investigação de 100 fatores associados à evolução para cirrose entre pacientes com hepatite crônica pelo vírus $B$ para cirrose hepática.

Tabela 17 Características sorológicas e histopatológicas dos pacientes que evoluíram para cirrose, segundo história de tratamento. Serviço de Assistência Especializada*. 2000 a 2009. Rio Branco, Acre, Brasil.

Tabela 18 Características bioquímicas no início e no final do seguimento 104 dos pacientes que evoluíram para cirrose, segundo história de tratamento. no Serviço de Assistência Especializada, 2000 a 2010. Rio Branco, Acre, Brasil. 


\section{LISTA DE FIGURAS}

Figura 1 História natural da infecção pelo VHB adquirido perinatalmente

ou durante a infância

Figura 2 VHB- Replicação e evolução da infecção crônica

Figura 3 Resposta celular imune para o VHB

Figura 4 VHB-Virion e organização genômica

Figura 5 Vírus da hepatite $B$

Figura 6 Ciclo replicativo do VHB

Figura 7 Distribuição dos genótipos do VHB no Mundo

Figura 8 Padrão sorológico e clínico após infecção aguda pelo VHB

Figura 9 Medicamentos aprovados para o tratamento da infecção crônica pelo VHB ao longo do tempo

Figura 10 Distribuição do VHB e delta com respectivos genótipos no Brasil

Figura 11 Distribuição do vírus da hepatite delta no Mundo

Figura 12 História natural da superinfecção pelo VHD

Figura 13 Localização do Estado do Acre na Amazônia Brasileira e suas regionais

Figura 14 Número de pacientes cadastrados no ambulatório de hepatites do SAE, com diagnóstico de hepatopatia crônica até dezembro de 2009

Figura 15 Possível modo de contágio dos portadores crônico do vírus da hepatite B acompanhados no Serviço de Assistência Especializada*. 2000 a 2009. Rio Branco, Acre, Brasil.

Figura 16 Provável tipo de exposição ao vírus da hepatite $B$ dos portadores crônico do vírus da hepatite $B$ acompanhados no Serviço de Assistência Especializada*. 2000 a 2009. Rio Branco, Acre, Brasil. 


\section{LISTA DE QUADROS}

Quadro 1. Gasto anual de cinco estágios evolutivos da hepatite B crônica, em diferentes países

Quadro 2 Fatores de risco para progressão da infecção pelo VHB

Quadro 3 Genótipo do VHB, mutações e relevância clínica

Quadro 4 Padrões sorológicos da infecção crônica pelo VHB

Quadro 5 Sistema de escore de graduação de atividade inflamatória e 41 fibrose hepática-SCORE METAVIR

Quadro 6 Relação entre genótipo do VHD, sua distribuição geográfica e clínica 


\section{INTRODUÇÃO}

Infecção pelo vírus da hepatite B (VHB) constitui um relevante problema de saúde pública em todo o globo, dois bilhões de pessoas, no mundo, já entraram em contato com o VHB, estima-se que 360 milhões de indivíduos sejam portadores crônicos, com 1,2 milhões de mortes anualmente por doença hepática relacionada ao VHB (OCAMA et al., 2005), sendo 50 mil por hepatite aguda e de 200 e 300 mil, respectivamente, por cirrose ou câncer de figado (EASL, 2003; PERZ et al., 2006).

Dos 360 milhões de portadores crônicos do VHB, distribuídos ao redor do mundo, 18 milhões estariam também, infectados pelo vírus da hepatite delta (VHD), predominantemente na Bacia Mediterrânea européia e norteafricana. Na América do Sul, a infecção pelo VHD está restrita à região Amazônica. No Brasil, nas áreas hiperendêmicas para o VHB, a prevalência do anti delta total, varia de $1,7 \%$ a $66,6 \%$ dependendo da população estudada (BENSABATH et al., 1987; DE PAULA et al., 2001; FONSECA, 2002; VIANA et al., 2005).

No Brasil, em 2002, foi criado o Programa Nacional para prevenção e controle das hepatites virais (PNHV), com missão de reduzir a incidência das hepatites virais e melhorar a qualidadde de vida dos portadores da doença, através de ações de prevenção, vigilância, controle e assistência, no território nacional, respeitando os princípios e as diretrizes do Sistema Único de Saúde (SUS), diminuindo o impacto negativo desse agravo, que mata milhares de brasileiros (MS, 2002).

Os conhecimentos a respeito da infecção pelos VHB, VHC e delta, o desenvolvimento de arsenal diagnóstico e terapêutico eficiente, na última década, tem ocorrido de forma acelerada, permitindo o aprimoramento dos programas voltados para $\circ$ monitoramento, controle, prevenção e assistência, criando condições para queda da morbimortalidade. 
Para fortalecer a construção de políticas públicas de saúde, o Brasil necessita de estudos sobre a história natural da infecção pelo VHB, que estimem a incidência de cirrose, que verifiquem as características dos virus circulantes e sua evolução clínica, que descrevam o padrão de resposta ao tratamento, tendo com isto, dados que possam subsidiar condutas clínicas e intervenções de saúde pública.

Em nosso País, estudo de coorte de indivíduos infectados pelo VHB inexiste. Este estudo de coorte tem como aspecto inovador em nosso meio, o fato de analisar os fatores preditores de progressão para cirrose, na infeç̧ão crônica pelo VHB, da taxa de incidência de cirrose, permitindo a comparação com os já identificados na literatura, além do fato de que sido desenvolvido na região Norte do País, local de alta prevalência de infecção pelo VHB e VHD. Além disso, pode também auxiliar na discussão a respeito dos recursos necessários para garantir que a maior parte dos infectados pelo VHB tenha acesso e boa adesão aos tratamentos disponiveis, de forma a prevenir ou prolongar ao máximo o tempo de evolução para cirrose.

Também suscita a necessidade de o Serviço de Assistência Especializada se transformar em um centro de referência e treinamento, onde possa dispor de dados uniformizados para podermos estudar a história natural da hepatite $B$ e Delta no nosso meio, de observarmos a influência do tratamento sobre este agravo e de contribuir para o planejamento dos programas de controle da hepatite $B$ e prevenção do vírus delta em pacientes portadores crônicos do VHB.

Embora não seja objetivo deste estudo, podemos, através dele, verificar o impacto da política brasileira de prevenção e controle das hepatites através do SUS, que disponibiliza a vacinação contra o VHB desde a década de 80, em algumas regiões da Amazonia Legal (Boca do Acre e Lábrea) e apartir da década de 90 para as outras regiões do Brasil, inicialmente nas áreas de alta prevalência e depois para toda a população brasileira menor de um ano de idade, com ampliação da faixa etária ao longo do tempo, e os medicamentos para o tratamento da hepatite $B$ crônica com acesso gratuito e universal (MS, 2002; MS, 2003). 


\subsection{ASPECTOS CLÍNICOS}

A infecção pelo VHB segue um curso clínico de uma hepatite aguda ictérica ou anictérica, evoluindo para cura ou para cronificação. A progressão da forma crônica da doença depende de vários fatores relativos ao agente, hospedeiro e outros fatores. Entre os fatores relacionados ao agente, temos a replicação viral, definida pela presença de alto nível da carga viral $\left(>10^{5}\right.$. $10^{6}$ cópias $/ \mathrm{ml}$ ou 200 mil - 2 milhões UI) ou HBeAg positivo, genótipos, mutações e infecção concorrente com o vírus C, delta e HIV; do hospedeiro, temos a idade à época da infecção, sexo e características do sistema imune do indivíduo, determinando a expressão da doença. Quanto a outros fatores, temos o consumo pesado de álcool, fatores metabólicos e hepatotoxinas como a aflotoxina e tabaco (LOK \& MCMAHON, 2007; FATTOVICH et al., 2008).

Fundamentada na interação vírus-hospedeiro, a história natural da hepatite $B$ pode ser dividida em quatro fases: a) imunotolerância- ocorre quando a transmissão é perinatal, podendo permanecer por uma a quatro décadas, b) clareamento viral ou imunoativa, que ocorre após a transmissão horizontal entre crianças ou na fase adulta ou tardiamente nas pessoas que adquiriram a infecção verticalmente (maternal), c) sem ou baixa replicação viral, d) reativação, considerada por alguns autores como um fenômeno biológico característico dos hepadnavirus (EASL, 2003; LOK \& McMAHON, 2007; FATTOVICH et al., 2008; LIAW \& CHU, 2009; LIAW, 2009; HADZIYANNIS, 2011), Figura 1.

A história natural da hepatite B crônica difere de acordo com o momento da aquisição da infecção: se perinatal, pós-natal ou na idade adulta, com taxa de soroconversão do $\mathrm{HBeAg}$ para antiHBe ao ano, de $2 \%$ a $5 \%, 14 \%$ a $16 \%$ e de $65 \%$ respectivamente (FATTOVICH et al., 2008; LIAW, 2009; HADZIYANNIS, 2011). A hepatite crônica B pode ser separada em duas formas distintas, baseada na presença do $\mathrm{HBeAg}$ no soro (vírus $B$ selvagem) ou na ausência do $\mathrm{HBeAg}$ e presença do Anti-HBe (vírus $B$ selvagem residual ou mutante pré-core/Core). Essas formas podem evoluir 
para cirrose hepática e carcinoma hepatocelular (DESMET et al., 1994; FATTOVICH et al., 2003; FATTOVICH et al., 2008; LIAW \& CHU, 2009; HADZIYANNIS, 2011).

A proporção de pacientes com hepatite B crônica $\mathrm{HBeAg}$ positivo que evoluem para cirrose hepática é de $0,5 \%$ a $5 \%$, enquanto que os $\mathrm{HBeAg}$ negativo atinge proporções de $8 \%$ a $10 \%$ (LEE, 1997; LOK \& McMAHON, 2007; LIAW \& CHU, 2009). Evolução para cirrose e carcinoma hepatocelular é mais freqüente quando a infecção ocorre no período perinatal (RUIZMORENO et al., 1999) e naqueles com hepatite crônica HBeAg negativo (FATTOVICH, 2003; HADZIYANNIS \& PAPATHEODORIDIS, 2006; LIAW \& $\mathrm{CHU}, 2009)$.

Figura 1. Historia Natural da infecção pelo VHB adquirido perinatalmente ou durante a infância.

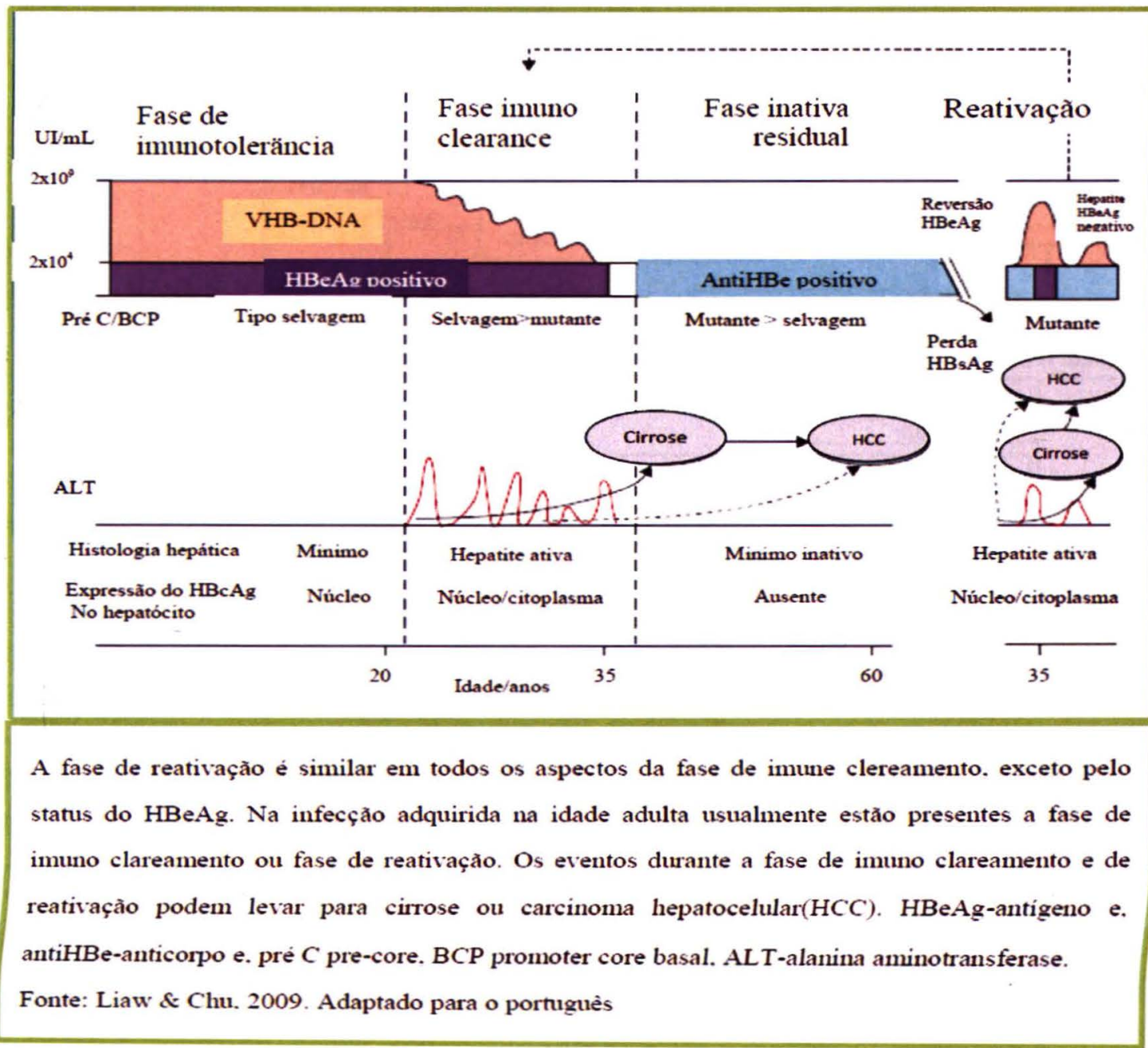


A história natural da cirrose é caracterizada por uma fase pré-clínica, denominada cirrose compensada, seguida por uma fase de progresso rápido, marcada pelo desenvolvimento de complicações, incluindo hipertensão portal ou disfunção hepática, denominado de cirrose descompensada (D'AMICO et al., 2006). A descompensação da cirrose ocorre em $4 \%$ ao ano e a evolução para carcinoma hepatocelular em $2 \%$ a $3 \%$, sendo que 0 portador inativo também pode evoluir para carcinoma hepatocelular em $0,02 \%$ a $0,2 \%$ dos casos. Tanto a cirrose descompensada quanto o carcinoma hepatocelular podem evoluir para morte em torno de $3 \%$ ao ano (FATTOVICH et al., 2008; LIAW \& CHU, 2009), Figura 2.

Figura 2. VHB replicação e evolução da infecção crônica.

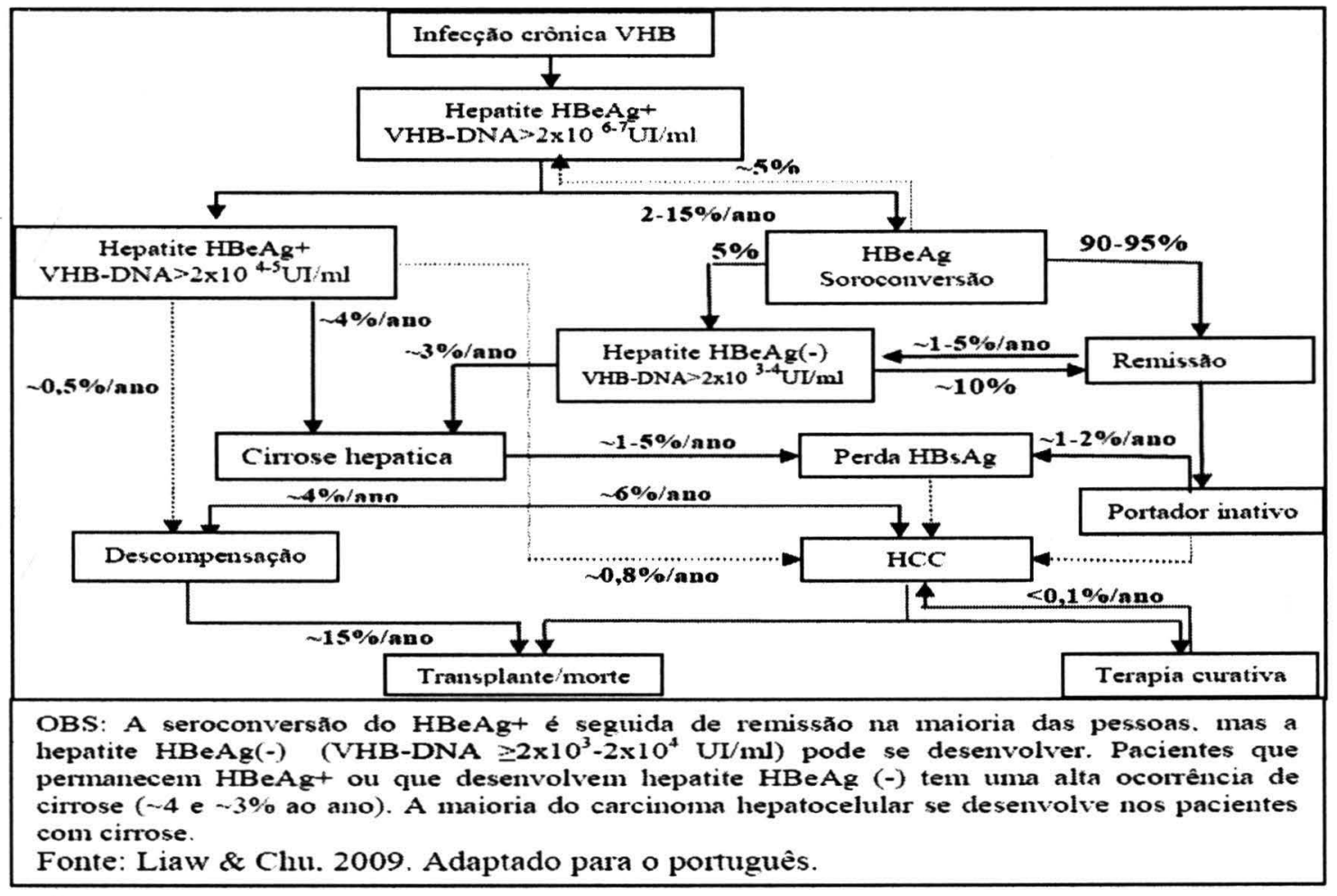

O curso natural da infecção pelo vírus $\mathrm{B}$ pode ser modificado pela associação com o vírus delta (VHD) que depende do vírus da hepatite $B$ (VHB) para sua replicação e pode ocorrer na forma de co-infeç̧ão, quando a infecção ocorre simultaneamente com $\circ \mathrm{VHB}$ ou superinfectando um portador do VHB. No primeiro caso, o paciente tenderá a desenvolver uma doença aguda, mais grave, aumentando o risco de evolução para formas 
fulminantes, com taxa de cronificação em torno de 5\%. Já na superinfecção, o portador do VHB fará uma agudização causada pelo VHD com maior probabilidade de cronificação (mais de 90\%) e evolução mais grave da doença com rápida progressão para cirrose hepática e carcinoma hepatocelular (BENSABATH et al., 1983; FATTOVICH et al., 2008).

\subsection{IMUNOPATOGÊNIA}

O vírus da hepatite $B$ é um típico vírus não citopático que induz lesão tissular de variável severidade pela estimulação da resposta imune protetora, podendo simultaneamente, causar dano e proteção, eliminando o vírus intracelular pela destruição das células infectadas, quando é eficiente, ou conduzindo para uma doença necroinflamatória persistente, quando não o é (FERRARI et al.,1990). Entretanto, a destruição das células infectadas parece não ser o único mecanismo implicado na eliminação viral intracelular. Estudos em animais infectados pelo VHB e em hepatite humana mostram a importância do mecanismo não citolítico de proteção antiviral, através da estimulação das citocinas B (GUIDOTTI et al., 2001).

A resposta celular imunomediada (celular e humoral), expressada na fase precoce da infecção pelo $\mathrm{VHB}$, pode influenciar na subseqüente evolução da hepatite $B$, com a eliminação ou não do vírus, associada à inativação viral intracelualr produzida por citocinas (interferon gama e fator de necrose tumoral) liberados pelas células linfomononucleares (RAPICETTA et al., 2002). Sem dúvida, a recuperação está associada com a eficiente ativação de mecanismo da imunidade inata, que parece ser responsável pela inibição precoce da replicação viral. Ocorre que os hepatócitos durante a fase aguda expressam em sua superfície um complexo formado por peptídeos do core $(\mathrm{HBcAg})$ do $\mathrm{VHB}$ e proteínas da classe I do HLA. Uma ativação subseqüente de células $T$ específica para o VHB é crucial para complementar o efeito da imunidade inata e permitir o controle completo da replicação viral, através do reconhecimento pelo linfócito T citotóxico do complexo de peptídeos do core/MHC classe I que ao 
atacar o hepatócito infectado, produz a lise hepatocítica. Entretanto, o controle da infecção pode não ser completo sem o desenvolvimento rápido e eficiente de anticorpos neutralizantes anti-envelope (Anti-HBs), que são necessários para eliminar as partículas virais livres e inibir a transmissão do vírus de célula para célula (CHIARI\&FERRARI, 1995; GANEM \& PRINCE, 2004). Nos pacientes com hepatite $B$ crônica, não ocorre expressão da classe I do HLA, a resposta celular T, específica para o VHB, é fraca ou indetectável no sangue periférico e as células $T$ são atraídas para dentro do fígado infectado, onde são diluídas entre as células $T$ virais não-específicas e células não T, que são a população celular predominante no infiltrado intrahepático. A alta carga viral e o antígeno "e", podem ser os principais responsáveis pela hiporesponsividade das células $\mathrm{T}$, típicos em pacientes crônicos, pelo esgotamento da resposta de células $T$ e expansão de células T capaz de produzir citocinas Th2 (FERRARI et al., 1990; BERTOLETTI et al.1997; JUNG et al., 1991; GANEM \& PRINCE, 2004) (Figura 3).

Figura 3. Resposta celular imune para o VHB.

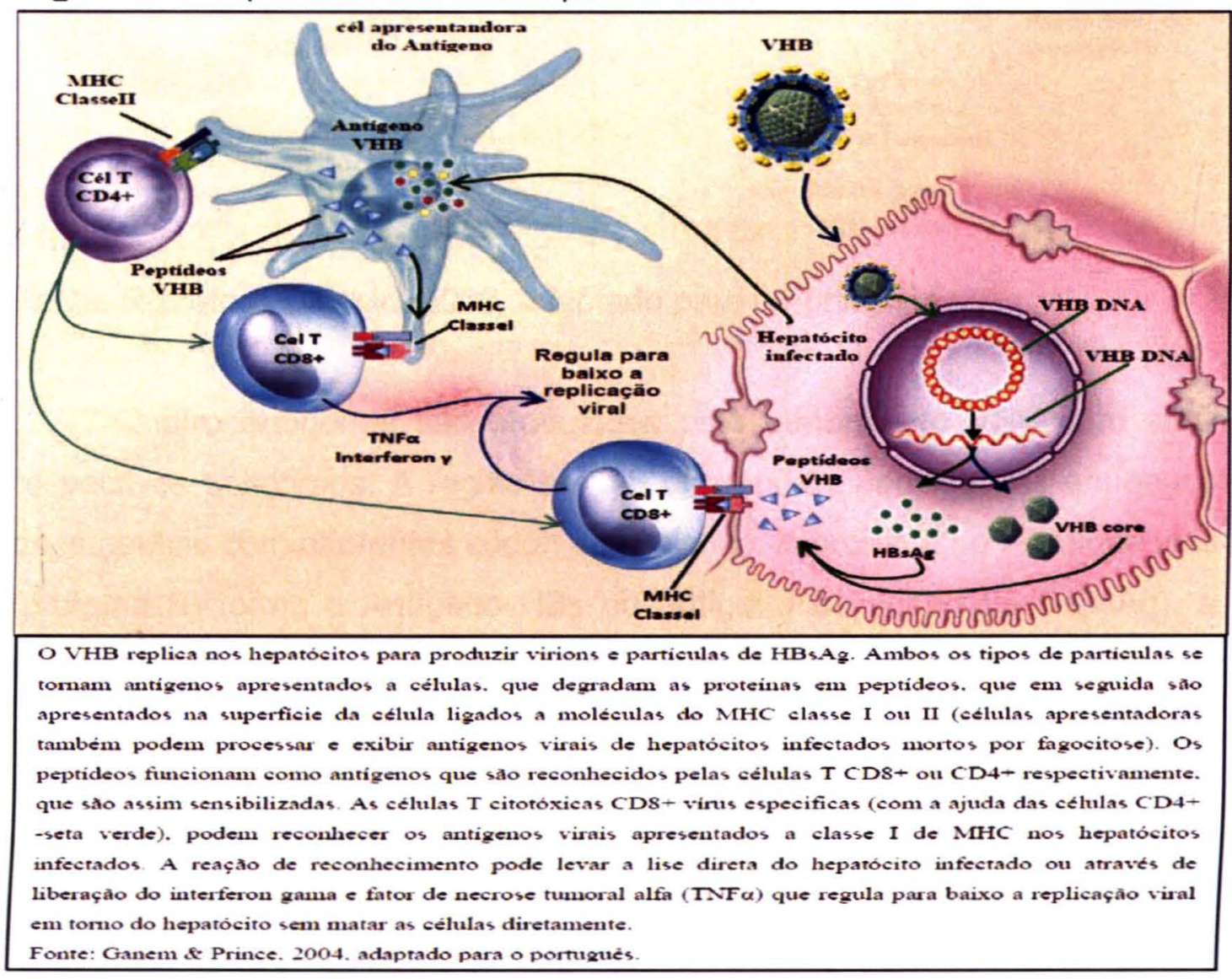




\subsection{CARACTERÍSTICAS DO AGENTE (VHB)}

$O$ vírus da hepatite $B(\mathrm{VHB})$ pertence à família Hepadnaviridae, é um vírus DNA, com $42 \mathrm{~nm}$ de diâmetro. Possui um genoma com 3200 nucleotídeos e se apresenta sob forma de partículas infecciosas ou partículas de DANE e partículas não infecciosas esféricas ou alongadas, que se formam devido à produção excessiva das proteinas de superfície (KIIDLJUNGGREN et al., 2002; GANEM \& PRINCE, 2004; HATZAKIS et al., 2006, RIZZETO \& CIANCIO, 2008), (Figura 4).

Figura 4. VHB- Virion e organização genômica

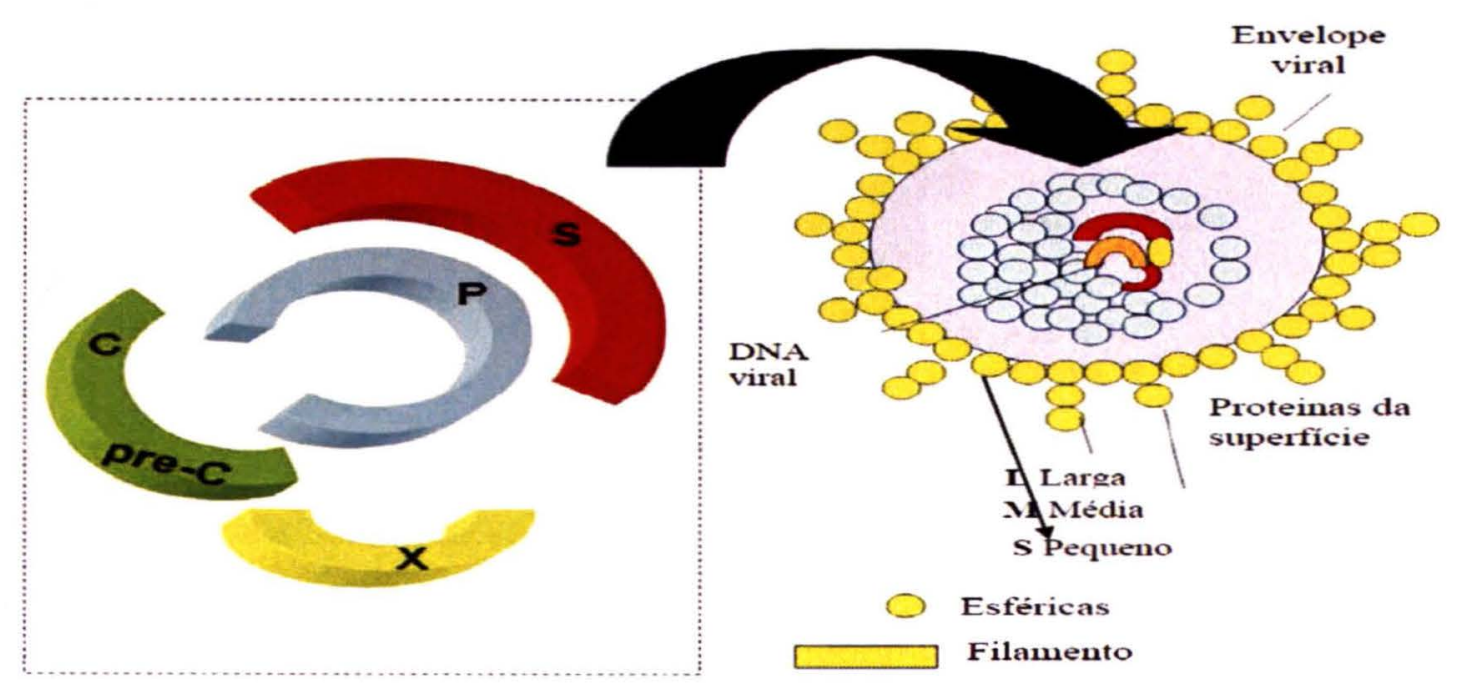

Fonte: Rizzeto \& Ciancio, 2008, adaptado para o português.

Quatro antígenos são produzidos pelo genoma do VHB com seus respectivos anticorpos. A região préS-S do genoma codifica três antígenos de superfície com diferentes códon de iniciação. A proteína do envelope viral (proteína S) forma o Antígeno HBs ou antígeno de superfície (HBsAg), a proteína $M$ (préS2), cuja função é desconhecida e a proteína $L$ (préS1), que acredita-se desempenhar um papel chave na ligação do vírus com os receptores da célula do hospedeiro, montagem do vírion e sua liberação da célula. As proteínas do envelope contêm epítopos neutralizantes que induzem à produção de anticorpos. Os epitopos são identificados na região 
S e pré S2. Os epitopos na proteína $S$ estão situados na região hidrofílica, região conhecida como determinante "a". Os anticorpos anti-HBs dirigidos contra esses epitopos neutralizam o vírus. A referida região é afetada por numerosas mutações. Uma simples substituição nesta região poderá originar importantes modificações no determinante "a" que escapará ao reconhecimento dos anticorpos anti-HBs circulantes (Figura 5).

Figura 5. Vírus da Hepatite B

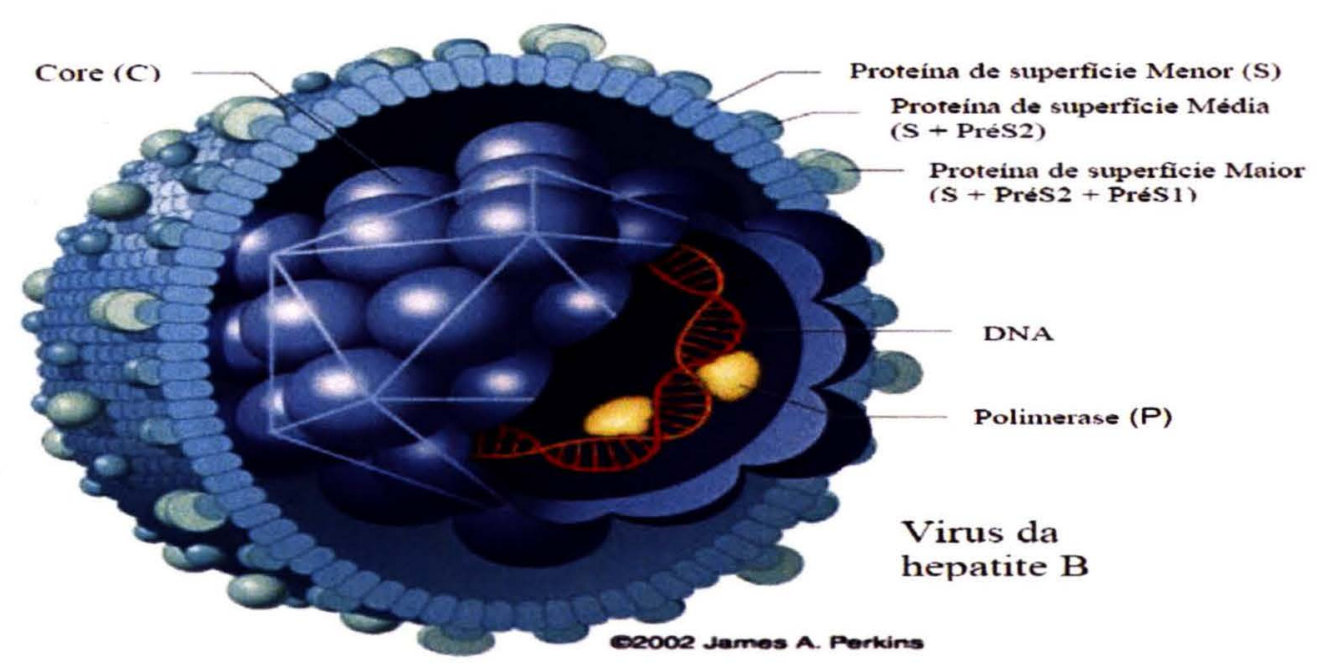

Fonte: http://people.rit.edu/japfaa/infectious.html

A região do préC-C, codifica o antígeno $\mathrm{HBc}$, nucleocapsídeo que protege o genoma viral, possui o Antígeno $\mathrm{HBc}$ ou proteína do core e $\circ$ Antígeno $\mathrm{HBe}$ (fração circulante da proteína do core), marcador de replicação ativa e de infectividade, (KIID-LJUNGGREN et al., 2002), embora - HBeAg não seja necessário para a replicação viral, a despeito dos mutantes que não sintetizam o $\mathrm{HBeAg}$ e continuam replicando (GANEM \& $P R I N C E$, 2004). A região $P$ é específica para polimerase viral, uma enzima multifuncional que envolve a síntese do DNA e encapsulamento do RNA.

A DNA Polimerase é a enzima de replicação do vírus, que ocorre através da transcrição reversa, utilizando-se de um tutor RNA para sintetizar o seu DNA complementar. As mutações que são encontradas em vírus DNA clássicos, a maioria surge nesta etapa. O vírus pode integrar uma parte de 
seu genoma (cccDNA) ao genoma do hepatócito, podendo este processo estar relacionado ao poder oncogênico que o VHB possui. A proteína $X$ (HBx) modula o sinal de transdução da célula hospedeira ou pode afetar direta ou indiretamente o hospedeiro e expressão viral. A atividade da proteína $X$ é requerida para a replicação in vivo e propagacão do vírus, (GANEM\&PRINCE, 2004), (Figura 6).

Figura 6. Ciclo replicativo do VHB.

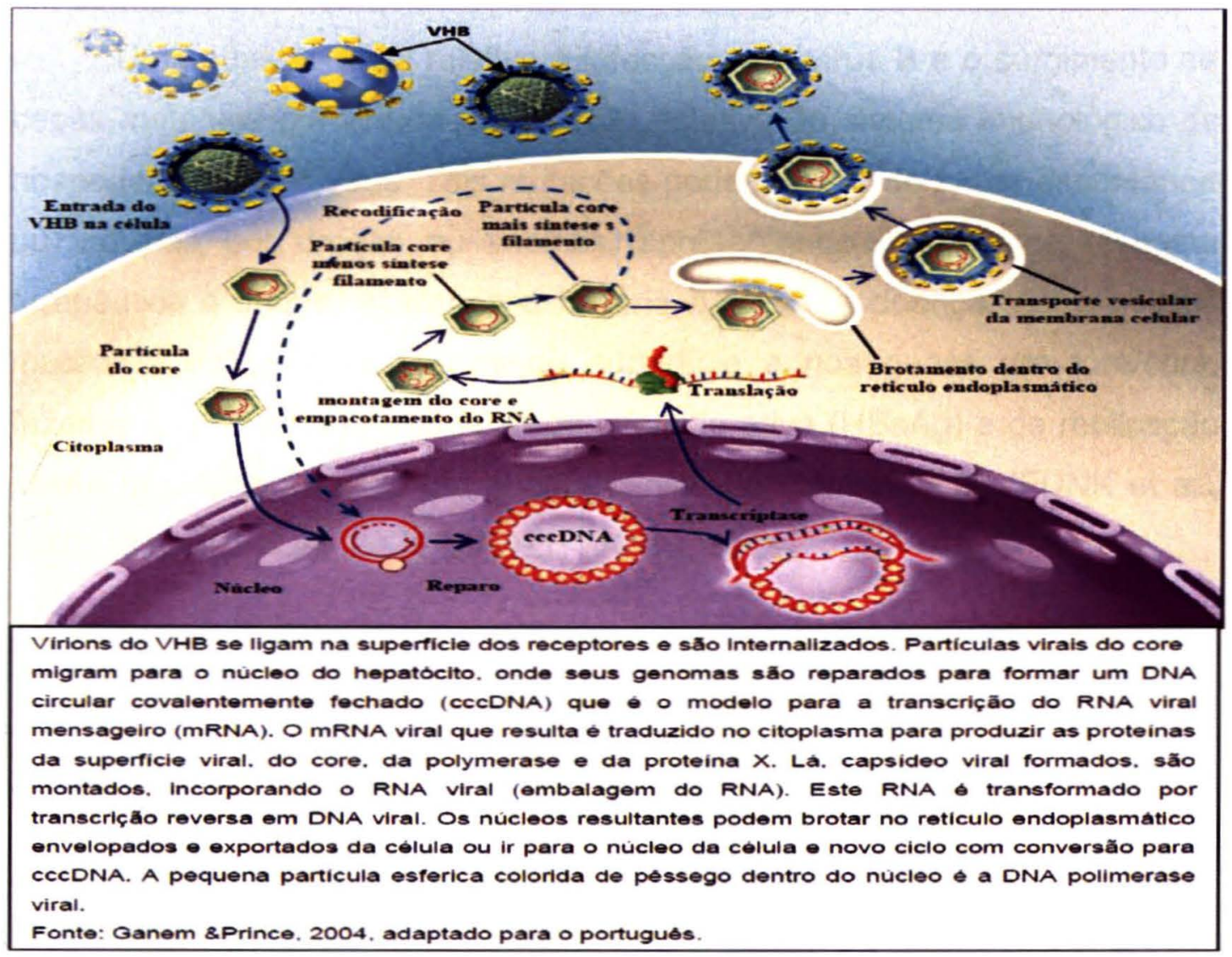

$O$ vírus da hepatite $B$ possui sete genótipos baseado na divergência de $8 \%$ nas seqüências de bases, com diferente distribuição geográfica e associados a diferentes mutações na região pré-core, core promoter basal que ocorrem durante a soroconversão do $\mathrm{HBeAg}$ para anti-HBe. As cepas mutantes pré-core escapam da sensibilização das células CD4/CD8 contra o $\mathrm{HBeAg}$, as cepas mutantes Pré-S escapam dos anticorpos neutralizantes anti-HBs e surgem após grandes programas de vacinação ou após transplante de fígado (OKAMOTO et al., 1988; NORDER et al., 1994; 
STUYVER et al., 2000). Os genótipos são designados pelas letras de A-G. Um oitavo genótipo foi descrito $(H)$ sendo filogeneticamente relacionado ao genótipo F (ARAUZ-RUIZ et al., 2002). Os seis genótipos maiores (A-F) têm distribuição geográfica distinta. As informações da distribuição geográfica e relevância clínica do genótipo $\mathrm{G}$, descoberto recentemente, são limitadas (MAGNIUS et al., 1995; KATO et al., 2002a; KATO et al 2002b; STUYVER et al., 2000; CAMPOS et al. 2005; PARANÁ \& ALMEIDA, 2005; SCHAEFER et al., 2007).

Uma questão atual relativa à infecção pelo vírus B é o surgimento de cepas mutantes em virtude da pressão seletiva do sistema imunológico do hospedeiro sobre o vírus. Tais mutações podem surgir de forma espontânea ou induzida por drogas ou vacinas, apresentando reflexos na resposta terapêutica e imune, alterando a história natural da doença. As principais mutações ocorrem nos genes de superfície e nos genes pré-core/core, fazendo com que os marcadores de infecção ativa (HBsAg) e de replicação sejam negativos frente a um quadro clínico de mal evolução (FUNK et al., 2002; KHOURI et al., 2004; HADZIYANNIS, 2011).

Figura 7. Distribuição dos genótipos do VHB no mundo.

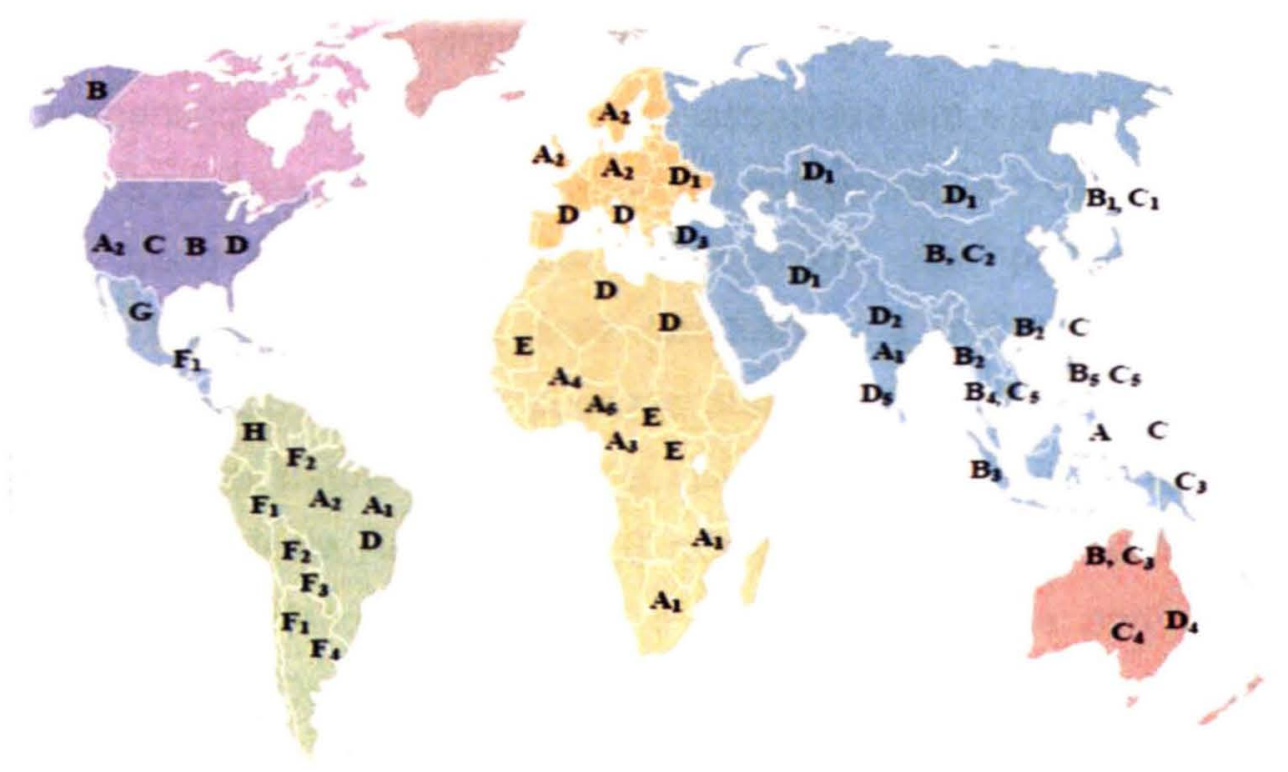




\subsection{EPIDEMIOLOGIA}

A distibuição global do VHB, baseada na prevalência do HBsAg, e seu padrão de transmissão variam nas diferentes partes do globo, sendo definidas como de alta ( $\geq 8 \%$ ), moderada $(2-7 \%)$ e baixa $(<2 \%)$ prevalência. O risco de desenvolver infecção crônica pelo VHB após a exposição varia de $70 \%$ a $90 \%$ quando a infecção é adquirida no período perinatal (vertical), de $20 \%$ a $50 \%$ quando adquiridas na infância precoce (horizontais, antes dos cinco anos) e de $1 \%$ a $3 \%$ nas infecções adquiridas na idade adulta (a menos que o indivíduo seja imunossuprimido, onde o risco é maior) (WHO, 2002; ALTER, 2003).

O VHB encontra-se presente nos fluidos corpóreos e é transmitido através da exposição percutânea ou da mucosa aos materiais ou equipamentos contaminados com fluidos que contem o VHB. Transmissão parenteral, perinatal, sexual e horizontal (contato interperssoal domiciliar), são as principais formas de transmissão, sua freqüência difere, de acordo com o padrão de prevalência do VHB (WHO, 2002; ALTER, 2003; BRASIL, 2003; LOBATO et al., 2006; UCMAK et al., 2007; ALI et al., 2009).

FATTOVICH et al., (2008) estimaram a incidência de progressão da infecção crônica pelo vírus B para cirrose, carcinoma hepatocelular, descompensação e mortalidade a ela associada em estudos longitudinais, realizados na Ásia e Europa, levando em consideração o estágio da doença e área geográfica. Tal estudo apontou que, nos portadores inativos, independentemente de sua área geográfica, a incidência para cirrose situava-se abaixo de 0,1/100 pessoas ano; entre os com hepatite crônica, dependendo do status do $\mathrm{HBeAg}$, a incidência foi de 1,6/100 pessoas/ano nos países do leste Asiáticos e 3,8 nos países Europeus, com incidência acumulada em cinco anos de $8 \%$ e $17 \%$ entre os que apresentavam o HBeAg positivo. Quando HBeAg negativo, a incidencia foi de 2,8 na Ásia e 9,7 na Europa, sendo a incidência acumulada em 5 anos de $13 \%$ e $38 \%$, respectivamente. 
Quanto à progressão para carcinoma hepatocelular, nos estudos conduzidos nos paises do Oriente Asiático a incidência foi de 0,2/100 pessoas/ano entre os portadores inativos, 0,6 entre os com hepatite crônica sem cirrose e 3,7 nos indivíduos com cirrose compensada sendo a incidência acumulada em cinco anos, respectivamente, de $1 \%$, 3\% e $17 \%$, com média de idade no diagnóstico de 59 anos (FATTOVICH et al., 2008). Nos estudos Europeus e nos Estados Unidos, a incidência é 0,02/100 pessoas/ano nos portadores inativos, 0,3 nos pacientes com hepatite crônica sem cirrose e 2,2/100 pessoa-ano naqueles com cirrose compensada, correspondendo em cinco anos, a incidência acumulada de carcinoma hepatocelular de $0,1 \%, 1 \%$ e $10 \%$, sendo a média de idade no diagnóstico de 63 anos (FATTOVICH et al., 2008).

A incidência de descompensação hepática e ou hemorragia por varizes gastresofágicas foi de 3-4/100 pessoas/ano em pacientes no estágio inicial de cirrose em ambos os estudos (Asiático e Europeu) com incidência acumulada em cinco anos de $15 \%$. A média de idade variou de 55 a 60 anos. Quanto à taxa de mortalidade associada à hepatite $B$, esta foi de $0,03 / 100$ pessoa/ano entre os portadores inativos $e$, menor que $0,1 / 100$ pessoa-ano, naqueles com hepatite crônica sem cirrose nos estudos europeus e asiático (FATTOVICH et al., 2008).

Já nos pacientes com cirrose compensada, a taxa de mortalidade associada à hepatite $\mathrm{B}$ é de 3,3 e 2,9/100 pessoas/ano na Europa e Ásia, respectivamente, sendo a taxa acumulada em cinco anos de $15 \%$ e $14 \%$, respectivamente. Na cirrose descompensada, a taxa aumenta de $70 \%$ para $80 \%$ em cinco anos. As taxas de mortalidade aumentam quanto maior for o número de complicações (FATTOVICH et al., 2008).

O impacto econômico associado à hepatite crônica pelo vírus $B$ [Quadro 1] é importante, pois, em áreas endêmicas o desenvolvimento de cirrose e carcinoma hepatocelular em fase precoce da vida, compromete justamente o período economicamente produtivo dos pacientes. $\mathrm{O}$ custo do tratamento dos pacientes com hepatite B é elevado, aumentando de forma drástica nos estágios mais avançados da doença pela elevada freqüência de 
intercorrências clínicas e mortalidade associada à cirrose e o HCC. Os gastos elevam-se de acordo com o estágio evolutivo da hepatite crônica, sendo os procedimentos e medicamentos os componentes principais do gasto (CASTELO et al., 2007).

Quadro 1. Gasto anual segundo o estádio clínico da hepatite B crônica, em diferentes paises.

\begin{tabular}{|c|c|c|c|c|c|c|}
\hline $\begin{array}{c}\text { Pais } \\
\text { ano de estudo }\end{array}$ & $\begin{array}{l}\text { Hepatite } \\
\text { crônica }\end{array}$ & $\begin{array}{l}\text { Cirros } \\
\text { Compen- } \\
\text { sada }\end{array}$ & $\begin{array}{l}\text { Cirrose } \\
\text { Descom- } \\
\text { pensada }\end{array}$ & $\begin{array}{c}\text { Carcinoma } \\
\text { Hepato- } \\
\text { celular }\end{array}$ & $\begin{array}{c}\text { Trans- } \\
\text { plante } \\
\text { hepático }\end{array}$ & Total \\
\hline & US\$ & US\$ & US\$ & US\$ & US\$ & US\$ \\
\hline França'-2001 & 1477 & 1532 & 11948 & 12637 & 114281 & 141875 \\
\hline Austrália²-2001 & 1019 & 1152 & 9885 & 9713 & 119332 & 141101 \\
\hline Reino Unido-2001 & 3956 & 4416 & 17642 & 18624 & 94306 & 138944 \\
\hline Itália'-2001 & 2487 & 2902 & 9813 & 9424 & 88535 & 113161 \\
\hline Estados Unidos-2000 & 761 & 227 & 11459 & 7533 & 86552 & 106532 \\
\hline Canadá -2001 & 1921 & 1921 & 3405 & 9849 & 86900 & 103996 \\
\hline Hong Kong-2000 & 810 & 1321 & 7490 & 15618 & 65961 & 91200 \\
\hline Coréia do Sul-2001 & 248 & 679 & 1419 & 3044 & 67156 & 72546 \\
\hline Cingapura-2003 & 410 & 671 & 8794 & 7036 & 49353 & 66264 \\
\hline Espanha'-2001 & 4589 & 5401 & 7151 & 5041 & 34006 & 56188 \\
\hline Brasil $^{5}-2005$ & 987 & 1411 & 8809 & 1905 & 334948 & 48060 \\
\hline China -2002 & 142 & 185 & 1701 & 4740 & - & 6768 \\
\hline
\end{tabular}

Fonte: Castelo, 2007, 'Cambio:. U US $\$ 1=0,74 ;{ }^{2}$ Cambio: US $\$ 1=A U D \$ 1,21$; Cambio:US $\$ 1=0,50$; Cambio:US $\$ 1=C A D \$ 1,14$ Cambio:US $\$ 1=R \$ 2,50$

\subsection{FATORES DE RISCO PARA FORMAS GRAVES}

A hepatite B crônica é uma doença progressiva, com risco de desenvolvimento de cirrose em até cinco anos em pacientes com hepatite crônica ativa, com aumento de incidência de carcinoma hepatocelular primário. Isto tudo ocorre dentro de um complexo e variado padrão clinico e uma heterogeneidade de progressão da doença, que é resultado da inflamação hepática e subseqüente fibrose, com variação de espectro clínico, bioquímico e histológico entre o portador inativo e o com hepatite crônica, com ou sem marcadores de replicação viral (HBeAg e HBV-DNA), condicionado à interação vírus-hospedeiro, sendo importante nesta evolução; os fatores virais (diversidade de genomas, mutações e carga viral), os fatores do hospedeiro (idade, alteração de transaminases, estadiamento histológico, exacerbações (flares) recorrentes) e fatores externos (álcool, drogas - hepatotoxinas e co-infecção com VHD, HIV e 
VHC) (FATTOVICH et al., 1999; FATTOVICH, 2004; LIN \& KAO, 2008; LIAW, 2009; ALAM et al., 2011; BEKKU et al., 2011), [Quadro 2].

$\mathrm{Na}$ hepatite B crônica aproximadamente $10 \%$ a $20 \%$ dos pacientes têm a cirrose como a primeira manifestação clinica. Cerca de $20 \%$ a $30 \%$ daqueles que não têm cirrose, na fase inicial da doença, podem desenvolvêla dez anos após, acompanhada com suas complicações (carcinoma hepatocelular, ascite, encefalopatia e hemorragia digestiva por varizes de esôfago) podendo evoluir para morte em conseqüência do estágio final da doença hepática (BENVEGNU' et al., 2004).

Quadro 2 - Fatores de risco associados à progressão da infecção crônica pelo VHB

\begin{tabular}{|l|l|l|}
\hline Fatores virais & Fatores do hospedeiro & Fatores externos \\
\hline $\begin{array}{c}\text { VHB-DNA } \\
\text { elevado }\end{array}$ & Idade avançada & Álcool \\
\hline Mutações & $\begin{array}{c}\text { ALT persistentemente } \\
\text { elevada }\end{array}$ & Drogas \\
\hline Genótipos & Flares recorrentes & $\begin{array}{c}\text { Co-infecção com VHD, VHC, } \\
\text { HIV }\end{array}$ \\
\hline & Estadiamento histológico & \\
\hline
\end{tabular}

Fonte: Fattovich, 2004, Fattovich et al., 2008

Os fatores que têm impacto sobre a progressão da hepatite crônica para cirrose e carcinoma hepatocelular nos diversos estudos são: idade maior que 40 anos, pelo maior tempo de infecção e de doença hepática; sexo masculino, apresentando risco três a seis vezes maior; explicado possivelmente pelo papel protetor do estrogeneo nas mulheres, a severidade da fibrose (F3>F1 ou $F 2$ ); repetidas exacerbações com falência da supressão do VHB; com alaninoaminotransferase (ALT) persistentemente elevadas (elevações intermitentes das aminotransferase 10 vezes ou mais o limite normal ou mais do que duas vezes o valor do baseline) ou com elevações sem normalização das transaminases (HUO et al., 2000; FATTOVICH et al., 2002; SHIMIZU et al., 2007).

As mutações do VHB estão associadas com dano hepático mais severo, sendo que as do core promoter (BCP - A1762T/G1764A) estão relacionadas com maior risco de desenvolver carcinoma hepatocelular 
independentemente do genótipo e carga viral (LIU et al., 2006a; LIU et al., 2006b). A carga viral maior ou igual a $10^{4}$ é forte preditor de risco para evolução para cirrose e carcinoma hepatocelular, independente do nível de ALT e status do HBeAg (ILOEJE et al., 2006; CHEN et al., 2006).

A influência do genótipo sobre a evolução clínica e à resposta a terapia antiviral tem sido apontada por vários estudos, especialmente entre os genótipos $A$ e $D$, sendo que o $D$ estaria associado à maior risco de evolução para hepatite crônica $\mathrm{HBeAg}$ negativo e a pior resposta ao interferon quando comparado com o genótipo A (CHU et al., 2005; KAO et al., 2002; MAYERAT et al., 1999; WAl et al., 2002, HADZIYANNIS, 2011). O genótipo $\mathrm{C}$ causa doença mais grave do que o $\mathrm{B}$, sendo preditor de desenvolvimento de cirrose ( $\mathrm{CHU}$ et al., 2005) e carcinoma hepatocelular (YU et al., 2005). O genótipo D está associado com doença hepática progressiva quando comparado ao genótipo A (THAKUR et al., 2002; SANCHEZ-TAPIAS et al., 2002) [Guadro 3]. Quanto aos genótipos F e H pouco se conhece da sua importância sobre a evolução clínica da hepatite crônica $B$, parece que o genótipo $F$ apresenta comportamento distinto daquelas associadas aos demais genótipos, com evolução precoce para cirrose e HCC, principalmente quando associado ao VHD (ARAUZ-RUIZ et al., 2002; PARANÁ et al., 2006).

Quadro 3. Genótipo do VHB, mutações e relevância clínica

\begin{tabular}{|c|c|c|c|c|}
\hline \multirow[b]{2}{*}{ Genótipo } & \multirow[b]{2}{*}{ Subtipo } & \multicolumn{2}{|c|}{ Frequéncia de Mutação† } & \multirow[b]{2}{*}{ Clínica } \\
\hline & & PC & BCP & \\
\hline$A$ & Adw2, ayw1 & $\begin{array}{l}\text { Incomum } \\
\text { (C1858) }\end{array}$ & Comum & $\begin{array}{l}\text { Responde ao interferon- } \mathrm{A} \text { melhor que o D } \\
\mathrm{Aa} \text { associado a } \mathrm{CHC} \text { em adultos jovens }\end{array}$ \\
\hline B & Adw2, ayw1 & $\begin{array}{l}\text { Comum } \\
\text { (T1858) }\end{array}$ & Comum & $\begin{array}{l}\text { Seroconversão } \mathrm{HBeAg} \text { idade precoce }-\mathrm{B}>\mathrm{C} \\
\text { Doença hepática mais severa }-\mathrm{Ba}>\mathrm{Bj} \\
\text { Melhor resposta ao tratamento- } \mathrm{Bj}>\mathrm{Ba}\end{array}$ \\
\hline C & $\begin{array}{l}\text { adw2, adrq+, } \\
\text { adqr-, ayr, adr }\end{array}$ & $\begin{array}{l}\text { Comum } \\
\text { (T1858) }\end{array}$ & Comum & Doença hepática mais severa $-\mathrm{C}>\mathrm{B}$ \\
\hline $\bar{D}$ & $\begin{array}{l}\text { ayw2, ayw3, } \\
\text { ayw4 }\end{array}$ & $\begin{array}{l}\text { Comum } \\
\text { (T1858) }\end{array}$ & Comum & $\begin{array}{l}\text { Maior risco de hepatite crônica } \mathrm{HBeAg} \\
\text { negativo e cirrose }-\mathrm{D}>\mathrm{A}\end{array}$ \\
\hline$E$ & ayw4 & ND & ND & Não se conhece \\
\hline$F$ & $\begin{array}{l}\text { adw4-, adw2, } \\
\text { ayw4 }\end{array}$ & $\begin{array}{l}\text { Incomum } \\
\text { (T1858) }\end{array}$ & ND & Não se conhece \\
\hline $\bar{G}$ & adw2 & $\begin{array}{l}\text { Muito comum } \\
\text { inserção }\end{array}$ & ND & Não se conhece \\
\hline $\mathrm{H}$ & adw4 & & & Não se conhece \\
\hline
\end{tabular}

Fonte: Locarnini et al, 2003, adaptado. †PC = mutação Precore( G1896A); BCP = mutação base core promoter (A1762T, G1764A); comum (+ de $50 \%$ dos isolados);incomum (menos de $10 \%$ dos isolados); muito comum (maioria dos isolados); ND = não descrito. 
O tratamento antiviral da hepatite B crônica pode prevenir a progressão da doença hepática, principalmente nos pacientes que têm uma resposta sustentada, com supressão da carga viral, normalização das transaminases, seroconversão do $\mathrm{HBeAg}$ para anti-HBe, (BRUNETTO et al., 2002; LOK \& McMAHON, 2007).

A infecção concorrente com outras hepatites é de $10 \%$ a $15 \%$ para o vírus $\mathrm{C}$, principalmente nas áreas onde as duas infecções são endêmicas. Para o vírus delta, estima-se que $5 \%$ dos pacientes com infecção crônica pelo vírus $B$ têm o vírus $D$ e com o HIV existe uma variação de $5 \%$ a $10 \%$ no Oeste Europeu e Estados Unidos para 20\% a 30\% na Ásia e parte da África Sub-Sahariana (SHEEN et al.,1994; FATTOVICH et al., 2008). No Brasil, a infecção concorrente do VHB com HIV, mostra uma variação de 3,8\% a 24,3\% (SOUZA et al. 2004; BRAGA et al., 2006; ZAGO et al., 2007), para o virus $\mathrm{C}$ e vírus $\mathrm{D}$, no Brasil como um todo, se desconhecem os dados.

O efeito das infecções concorrentes sobre o risco de progressão da doença hepática, em portadores crônicos do VHB, precisa ser mais bem entendido, a despeito de um grande número de estudos, tanto transversal como de caso-controle sobre o assunto, mostrando dados conflitantes sobre qual dos vírus seria o mais supressor. Os mecanismos que regulam a interação viral, não estão completamente definidos, alguns estudos mostram que a etnia, o genótipo, as mutações, teriam um papel importante em determinar a dominância viral, mas, o que esses estudos concordam é o risco do paciente com infecção crônica pelo VHB desenvolver cirrose é maior naqueles com infecção associada ao VHC e VHD (FONG et al., 1991; LIAW, 1995; POTISSO et al., 1996; SAGNELLI et al., 2000; JARDI et al., 2001; FATTOVICH et al., 2008; YURDAYDIN et al., 2010; NGUYEN et al., 2011).

O risco de desenvolver carcinoma hepatocelular é duas vezes maior entre os pacientes com infecção concorrente com o vírus $\mathrm{C}$ e três vezes maior com o vírus delta (FATTOVICH et al., 2008). Quando em associação com o HIV, estudos antes da era tratamento anti-retroviral (TARV) mostravam que a imunodeficiência relacionada ao HIV, modificava a história 
natural da infecção crônica pelo vírus $B$, com elevada replicação viral, baixa taxa de soroconversão do $\mathrm{HBeAg}$ e rápida progressão para cirrose. Após a introdução do TARV, os estudos mostram nos pacientes cirróticos coinfectados com VHB e HIV uma maior taxa de descompensação hepática, mas não de carcinoma hepatocelular, (PUOTI et al., 2006), porém o risco de morte relacionado à doença hepática diminui quando a lamivudina faz parte da terapia combinada (PUOTI et al., 2006).

Outros fatores como álcool, alterações metabólicas e hepatotoxinas (tabaco, aflotoxinas) parecem ter seu papel na progressão da infecção crônica pelo vírus $B$. Estudos mostram risco de dois a três vezes maiores de desenvolver carcinoma hepatocelular naqueles pacientes que fazem ingestão pesada de álcool (> 60g/dia) (DONATO et al., 2006). Não existem evidências conclusivas da possivel associação entre esteatose hepática e progressão da fibrose na hepatite crônica B. Alguns estudos não mostram associação enquanto que outros mostram um risco de duas vezes maior de progressão para cirrose (GORDAN et al., 2005; THOMOPOULOS et al., 2006).

O impacto da diabete e obesidade na progressão para cirrose e carcinoma hepatocelular foram avaliados em alguns estudos, mostrando em relação à diabete um risco de cinco vezes maior para cirrose e de 2,5 para carcinoma hepatocelular (EI-SERAG et al., 2006; DAVILA et al., 2005; HUO et al., 2000).

A obesidade abdominal central, resistência à insulina e adipoquinas profibrogênica estão fortemente relacionadas entre si e recente estudo demonstrou sua influência no desenvolvimento de fibrose em pacientes com hepatite B crônica (BONDINI et al., 2007). As hepatotoxinas (tabaco e aflotoxinas) podem aumentar o risco de carcinoma hepatocelular em 1,5 e 3,0 vezes, respectivamente, em homens infectados pelo VHB (YANG et al., 2002; MING et al., 2002; CHEN et al., 2006).

A cirrose hepática tem como característica a alteração da arquitetura hepática, com formação de septos fibrosos ao redor de nódulos parenquimatosos regenerados ou em regeneração, com comprometimento 
da microcirculação e anatomia vascular, em conseqüência da inflamação hepática. Apresenta uma fase pré-clínica (cirrose compensada) seguida por uma fase de progressão rápida (cirrose descompensada) devendo ser considerada duas versões separadas da doença, diferindo na apresentação clinica, mortalidade e preditores de morte (GINES et al.,1987; GARCIATSAO et al., 2008).

A história natural da cirrose compensada, de etiologia viral, tem sido matéria de grande interesse e freqüentes controvérsias. A magnitude e o tipo das complicações que ocorrem a cada tempo, nos diferentes subgrupos, assim como, a influência de fatores como, associação com outros vírus, o efeito do tratamento com medicamentos como o interferon, constituem alguns exemplos das controvérsias. A cirrose pode ser complicada por hipertensão portal, falência hepática ou carcinoma hepatocelular, os quais explicam juntos, $80 \%$ da morbidade e mortalidade associada ao VHB (GINES et al.,1987; GARCIA-TSAO et al., 2008).

Nos indivíduos com cirrose compensada, a característica bioquímica à época do baseline pode indicar uma doença hepática de longa duração (albumina, bilirrubinas e plaquetas), sendo importantes preditores do carcinoma hepatocelular, da ocorrência de descompensação e mortalidade associada à hepatite B (FATTOVICH et al., 2002, BEKKU et al., 2011). O papel da herança genética é sugerido pelo maior risco de carcinoma hepatocelular em pessoas com historia de carcinoma hepatocelular na familia (YU et al., 2000).

Estudos com pacientes recrutados nos diferentes estágios da cirrose, usualmente, permite identificar casos de hipertensão portal e suas manifestações (ascite e sangramento por ruptura de varizes de esôfago) como a causa mais freqüente de transição entre cirrose compensada, descompensada e morte relacionada ao fígado. Além disso, tais eventos têm reflexos sobre a taxa de sobrevida do indivíduo que varia de 52 a $82 \%$ em cinco anos. Mas recentemente, o carcinoma hepatocelular, também tem sido implicaco como uma das primeiras complicações que ocorre, marcando a descompensação da doença hepática, (BENVEGNU' et al., 2004). 
O diagnóstico da cirrose pode ser clínico-laboratorial ou pelo uso de técnicas de imagem e histopatológico, sendo que, a biopsia hepática constitui o padrão ouro para a diferenciação entre cirrose compensada e hepatite crônica. Porém é um procedimento invasivo, caro e não isento de riscos, além do que existem possibilidades de erros de amostragem e variabilidade inter-observador. Através das técnicas de imagem, o diagnóstico presuntivo de cirrose pode ser feito pela presença de bordo hepático irregular, diminuição hepática, dilatação de veia porta e ou esplênica na ultrassonografia, hipertensão portal com varizes de esôfago ou de fundo gástrico na endoscopia (YANG et al., 1988; CHEN et al., 2008). Como evidência laboratorial de doença hepática crônica avançada, temos diminuição de albumina, TAP alargado e aumento de bilirrubinas e gama GT. Estas enzimas são utilizadas nos diversos teste não invasivo de diagnóstico de cirrose (CHEN et al., 2008; PARK et al., 2010; LEE et al., 2011). Já no exame histológico, padrão ouro, é caracterizado pela presença de nódulos regenerativos ou em regeneração ( $F 3$ e F4). A cirrose pode ser classificada em estágios de acordo com o Score de Child-Pugh-Turcotte (CPT) que varia de 5 a 15 , estando baseada na presença e severidade da ascite e encefalopatia hepática, prolongamento do tempo da protrombina (TAP), nos niveis séricos de bilirrubinas e albumina. De acordo com seu score é classificado em três classes: Child A, B e C com scores CPT 5-6, 7-9 e 1015, respectivamente, (PAPATHEODORIDIS et al., 2005).

A gama glutamil transpeptidases, marcadora de lesão hepatocelular de alta sensibilidade, porém com baixa especificidade, uma vez que pode está alterada por uso de medicações, álcool e várias doenças sistêmicas, é um dos marcadores biológicos usado em teste não invasivo para diagnóstico de cirrose, (PRATT et al., 2000; DUFOUR et al., 2000; RANTALA et al., 2000; SUKUGAWA et al., 2004; PARK et al., 2010; LEE et al., 2011). 


\subsection{DIAGNÓSTICO DA INFECÇÃO PELO VHB}

O diagnóstico da infecção pelo VHB [Quadro 4] é feito pela investigação da presença no sangue dos marcadores sorológicos (antígenos e anticorpos) desse agente, após um período de incubação de quatro a 12 semanas. Na resolução da hepatite B o HBsAg e HBeAg desaparecem e os anticorpos (anti-HBs, anti-HBe) começam a ser detectados. A persistência do antígeno de superfície (HBsAg) por mais de seis meses define o portador crônico (FATTOVICH, 2008; LIAW \& CHU, 2009), Figura 8.

Figura 8. Padrão Sorológico e clinico após infecção aguda pelo VHB.

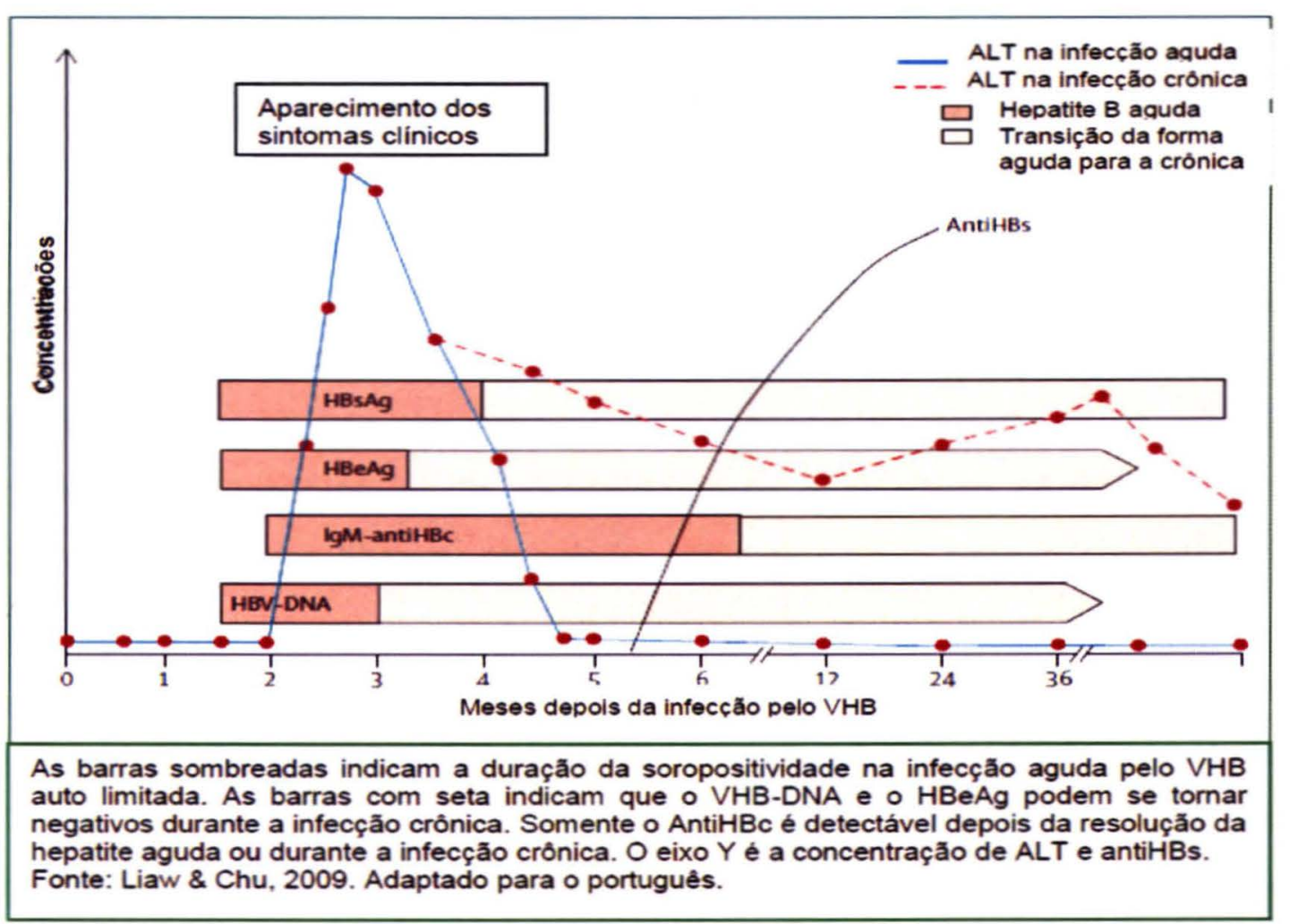

O ensaio VHB-DNA apropriado para a avaliação da infecção crônica pelo VHB não está bem definido. Um valor arbitrário de $>10^{5}$ cópias $/ \mathrm{ml}$ foi definido como sendo critério diagnóstico para a hepatite $B$ crônica. Os principais problemas com esta definição é que os testes de quantificação do VHB-DNA não estão standatizados, com diferentes níveis de limite de 
detecção e, os pacientes podem apresentar flutuações dos niveis do VHBDNA (CHU et al., 2002; LOK \&McMAHON, 2007).

Quadro 4. Padrões sorológicos da infecção crônica pelo VHB

\begin{tabular}{|l|c|c|c|c|c|c|}
\hline \multicolumn{1}{|c|}{ Marcadores } & HBsAg & HBeAg & Anti-HBe & Anti-HBc* & Anti-HBs & VHB-DNA \\
\hline Infecção crônica VHB & + & + & - & + & - & + \\
\hline Infecção oculta VHB & - & - & - & + & - & + \\
\hline Portador Inativo VHB & + & - & + & + & - & + \\
\hline Pré-core mutante & + & - & + & + & - & + \\
\hline Infecção passada & - & - & $+/-$ & $+/-$ & + & - \\
\hline
\end{tabular}

AntiHBcTotal (+) positivo, (-) negativo Fonte: Fonseca, 2007, adaptado

O diagnóstico da agressão hepática é feita através do exame histopatológico, que é o padrão ouro. Vários modelos para a classificação da agressão hepática foram propostos. O primeiro foi o de Knodell, Índice de Atividade Histológica (HAI) de 1981, que faz uma descrição semiquantitativa da lesão hepática. Em 1994, o grupo de Ishak, propôs uma revisão do modelo de Knodell, modificando-o para uma escala contínua de valores para descrever o grau de atividade e o estagio da fibrose separadamente. Em 1991 Scheuer propõe um sistema de avaliação (Score Scheuer) menos complexo que o $\mathrm{HAI}$, avalia separadamente a atividade portal/periportal, atividade lobular e fibrose, atribuindo um maior peso para o componente portal.

O Metavir Score (Quadro 5) foi proposto pelo Grupo de Estudo Frances Cooperativa-Metavir (BEDOSSA et al., 1994a, BEDOSSA et al., 1994b). Ele prevê pontuações distintas para a avaliação da atividade histológica e para o estágio de fibrose, refletindo uma combinação da necrose lobular, inflamação portal, necrose piecemeal (fragmentada) e necrose em ponte. A atividade é classificada de $\mathrm{AO}$ a $\mathrm{A} 3$ (atividade ausente a intensa atividade) e a fibrose F0 a F4 (ausência de fibrose a cirrose respectivamente).

No Brasil, o Consenso Nacional das Hepatites Cronicas da Sociedade Brasileira de Patologia (SBP), é utilizado em alguns serviços (GAYOTTO et al., 2007), (Tabela 1). 
Quadro 5. Sistema escore de graduação de atividade inflamatória e fibrose hepática - SCORE METAVIR.

\begin{tabular}{|l|l|l|l|}
\hline Graus & Atividade Portal/Periportal-A & Atividade Lobular & \multicolumn{1}{|c|}{ Fibrose-F } \\
\hline 0 & Não ou mínima & Não & Não \\
\hline 1 & Inflamação portal (HCP) & $\begin{array}{l}\text { Inflamação sem } \\
\text { necrose }\end{array}$ & Espaço porta alargado \\
\hline 2 & $\begin{array}{l}\text { Necrose periférica leve (HCA } \\
\text { leve) }\end{array}$ & $\begin{array}{l}\text { Necrose focal ou } \\
\text { corpos acidófilos }\end{array}$ & $\begin{array}{l}\text { Septos periportais ou porta- } \\
\text { porta com arquitetura } \\
\text { intacta }\end{array}$ \\
\hline 3 & $\begin{array}{l}\text { Necrose periférica moderada } \\
\text { (HCA moderada) }\end{array}$ & $\begin{array}{l}\text { Intensa lesão } \\
\text { celular focal }\end{array}$ & $\begin{array}{l}\text { Fibrose com distorção da } \\
\text { arquitetura distorcida sem } \\
\text { cirrose }\end{array}$ \\
\hline 4 & $\begin{array}{l}\text { Necrose periférica intensa } \\
\text { (HCA intensa) }\end{array}$ & $\begin{array}{l}\text { Lesão inclui } \\
\text { necrose em ponte }\end{array}$ & Provável ou cirrose definida \\
\hline
\end{tabular}

Bedossa et al. The French METAVIR Cooperative Study Group, 1994

Tabela 1. Equivalência aproximada das classificações mais usadas no estadiamento das hepatites crônicas

\begin{tabular}{|c|c|c|c|c|c|}
\hline \multicolumn{3}{|c|}{ Alteração Arquitetural (Fibrose)* } & \multicolumn{3}{|c|}{ Atividade inflamatória** } \\
\hline \multirow{2}{*}{$\begin{array}{l}\text { SBP } \\
2000\end{array}$} & \multirow{2}{*}{$\begin{array}{c}\text { Metavir } \\
1994\end{array}$} & \multirow{2}{*}{$\begin{array}{l}\text { Ishak } \\
1995\end{array}$} & \multicolumn{2}{|c|}{ SBP, 2000 e Ishak, 1995} & \multirow{2}{*}{$\begin{array}{c}\text { Metavir } \\
1994\end{array}$} \\
\hline & & & Atividade Periportal & Atividade Parenquimatosa $\mathrm{A}$ & \\
\hline 0 & 0 & 0 & 0 ou 1 & 0 & 0 \\
\hline 1 & 1 & 1 ou 2 & 0 ou 1 & 1 ou 2 & 1 \\
\hline 2 & 2 & 3 & 2 & $0-1$ & 1 \\
\hline 3 & 3 & 4 ou 5 & 2 & 2 & 2 \\
\hline \multirow[t]{4}{*}{4} & 4 & 6 & 2 & $3-4$ & 3 \\
\hline & & & 3 & $0-2$ & 2 \\
\hline & & & 3 & $3-4$ & 3 \\
\hline & & & 4 & $0-4$ & 3 \\
\hline
\end{tabular}

"na classificação de ISHAK, o escore de fibrose vai até 6 , enquanto no METAVIR e na SBP vai até 4. " "correspondendo a atividade periportal e parenquimatosa independentemente para SBP e ISHAK, e um misto de periportal e lobular para METAVIR, na classificação de METAVIR, o escore de atividade vai até 3 , enquanto no ISHAK e SBP vai até 4.

Fonte: SBI, 2006, adaptado

\subsection{TRATAMENTO DA HEPATITE B CRÔNICA}

Atualmente, a eficácia do tratamento da hepatite B crônica a longo prazo é limitada. Fatores como a idade do paciente, a severidade da doença, a probabilidade de resposta e a possibilidade de efeitos adversos e complicações devem ser considerados antes de decidir o tratamento (EASL, 2002).

O objetivo final do tratamento da hepatite B crônica é prevenir a cirrose, a descompensação hepática e o carcinoma hepatocelular, através 
da supressão sustentada da replicação do VHB e remissão da doença hepática. (LOK \& McMAHON, 2007).

Nos pacientes que respondem ao tratamento, que apresentam resposta sustentada, é cada vez maior a evidência de que, o tratamento antiviral pode prevenir a progressão da doença hepática. $O$ desfecho no tratamento da hepatite crônica $B$ incluem normalização dos níveis séricos de ALT (Resposta bioquímica - RB), VHB-DNA indetectável, perda do HBeAg com ou sem a detecção do anti-HBe (resposta virológica - RV) e melhora histológica (resposta histológica - RH). Existe ainda, como padrão de resposta ao tratamento, o paciente não-respondedor primário, breakthough virológico e bioquímico (elevação do VHB-DNA e das transaminases após alcançar resposta inicial durante o curso do tratamento) e relapso (EASL, 2001; LOK \& McMahon, 2007).

São sete os fármacos disponíveis para o tratamento da hepatite $B$ crônica: o interferon alfa (convencional e peguilado), a lamivudina, o entecavir, o tenofovir, o adefovir e a telbivudina (Figura 9). Eles têm demonstrado ser capazes de reduzir a concentração do VHB-DNA, das transaminases e melhorar a histologia hepática (KEEFFE et al., 2006). Enquanto o interferon é administrado com duração pré-definida os análogosnucleosi(ti)deos geralmente são administrados até que os desfechos específicos sejam conseguidos. A diferença está relacionada com o efeito imuno modulador do interferon (YUEN \& LAI, 2011).

Os pacientes $\mathrm{HBeAg}$ positivos conseguem uma supressão viral sustentada em $50 \%$ a $90 \%$ quando a suspensão do tratamento ocorre após a soroconversão do $\mathrm{HBeAg}$. Já nos $\mathrm{HBeAg}$ negativo, os relapsos são freqüentes mesmo com a supressão do VHB-DNA com niveis indetectáveis em ensaio de Reação em cadeia de polimerase (PCR) por mais de ano. Deste modo, o desfecho para parada do tratamento não é claro.

A maior preocupação com o tratamento por longo tempo com os análogosnucleosi(ti)deos é seleção de cepas mutantes resistentes ao antiviral. A taxa com os quais este mutantes são selecionados está relacionada com o nível sérico de VHB-DNA pré-tratamento, rapidez da 
supressão viral, duração do tratamento e exposição prévia à terapia com análogonucleosi(ti)deos, (BARTHOLOMEUSZ et al., 2006). A incidência de resistência genotípica também varia com a sensibilidade do método usado para detecção dos mutantes resistentes e da população que está sendo testada.

Entre os análogonucleosi(ti)deos aprovados para terapia da hepatite crônica $B$, a lamivudina está associada a maior e o entecavir e o tenofovir com a menor taxa de resistência em pacientes virgens de tratamento (naive).

Figura 9. Medicamentos aprovados para o tratamento da infecção cronica pelo VHB ao longo do tempo.

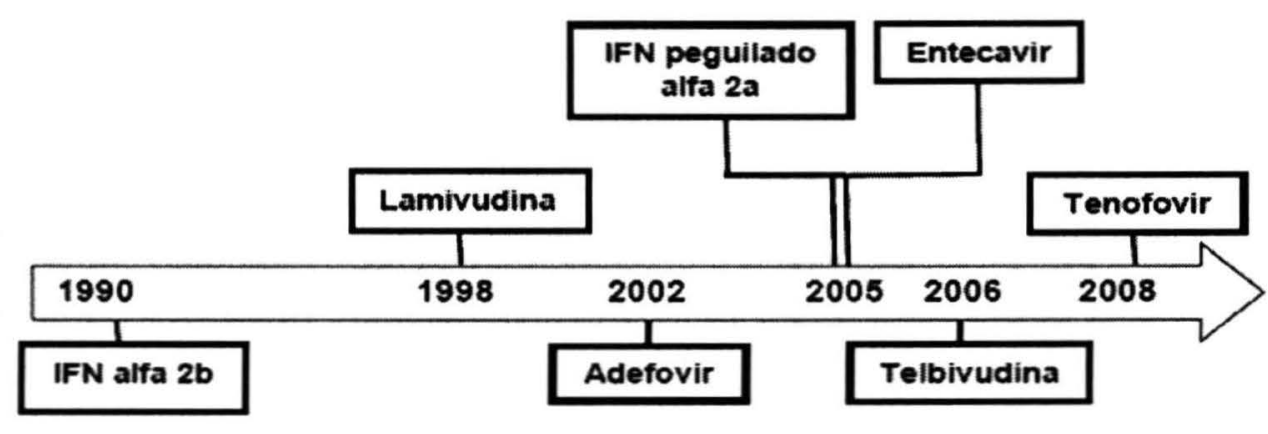

Terapia aprovada para hepatite B crónica ao longo do tempo.

Fonte: Yuen M-F \& Lai C-L, 2011. Adaptado para o português.

\subsection{IMUNOPROFILAXIA DA HEPATITE B}

A vacinação contra o vírus $B$ foi uma estratégia utilizada pela Organização Mundial de Saúde (WHO, 2003) na década de $80 \mathrm{com}$ o objetivo de controlar a infecção pelo VHB levando em consideração os padrões de transmissão nos diferentes países. Foi indicada inicialmente para todas as crianças ao nascimento nas áreas endêmicas. Em 2000, 116 paises já tinham adicionado a vacina da hepatite $B$ em seus programas de imunização. (CDC, 2004). 
Países com alta, baixa e intermediária endemicidade que implantaram a vacinação universal contra o vírus $B$ observaram uma diminuição dos casos de hepatite B aguda em adultos e de carcinoma hepatocelular em crianças, e uma menor prevalência de portadores crônicos do HBsAg entre crianças e adolescentes (WONG et al., 1994; LEE \& KO, 1997; HARPAZ et al., 2000; POOVORAWAN et al., 2011).

O impacto econômico dos programas de vacinação universal ainda necessita melhor avaliação, porque as complicações da infecção crônica pelo VHB permanecem por muitos anos. Entretanto, vários estudos de custo-efetividade mostram economia mesmo nos países de baixa $\mathrm{e}$ intermediária endemicidade (exemplo: Bélgica, Itália, Espanha, EUA), onde se observa uma redução na incidência da hepatite $B$ após a recomendação da vacinação para todos os recém nascidos e adolescentes em 1991 e 1996 respectivamente (DAVIS, 2005), contrapondo a estratégia de vacinação apenas de grupos de maior exposição, onde o custo/efetividade não é tão expressivo (FERREIRA et al., 2006), como em países de alta endemicidade com diminuição da morbi-mortalidade pela hepatite pelo $\mathrm{VHB}$, dos gastos em tratamento e a prevenção da infecção concomitante com o vírus da hepatite delta (HARPAZ et al., 2000; POOVORAWAN et al., 2011).

A imunização dos recém-nascidos previne tanto a transmissão vertical como a horizontal e sua subseqüente cronificação (FERREIRA et al., 2006), pois esta se relaciona inversamente com a idade.

A necessidade de doses de reforço, 15 anos após a vacinação inicial e o impacto da vacinação universal na seleção de escape mutantes $S$ é um campo aberto para estudo, devido a sua importância na mudança do perfil epidemiológico da hepatite B.

\subsection{CARACTERÍSTICAS DA INFECÇÃO PELO VHB NO BRASIL}

No Brasil a prevalência de infecção pelo VHB aumenta do Sul para o Norte do País (Figura 10). A região Sul é considerada como área de baixa endemicidade, as regiões Nordeste, Centro - Oeste e Sudeste são de 
moderada endemicidade. A região da Amazônia Legal, o estado do Espírito Santo e oeste de Santa Catarina e oeste do Paraná são considerados de alta endemicidade (MS, SVS, 2008).

Na região Amazônica a taxas de portadores crônicos do VHB ainda é uma das mais altas ( $3 \%$ a $20 \%$ ), atingindo crianças e adultos jovens, embora se observe uma diminuição da prevalência, como a que ocorreu em Labrea, após a introdução da vacina da hepatite B (BENSABATH et al.,1987; FONSECA et al., 1988; SOUTO et al., 1998; BRAGA et al., 2001; Braga et al., 2004; VIANA et al., 2005; KATSURAGAWA et al., 2010). Na região Norte, na bacia Amazônica, o padrão epidemiológico das infecções pelos vírus $B$ e Delta não é uniforme, localizando-se principalmente nos vales dos rios Juruá, Purus e Madeira, na Amazônia Ocidental e no vale do rio Tapajós na Amazônia Oriental (BENSABATH et al., 1983; FONSECA et al., 1988; BRAGA et al., 2001, VIANA et al., 2005).

Na Amazônia Ocidental, em portadores crônicos assintomáticos do VHB, foi encontrada uma prevalência de $24 \%$ a $34 \%$ de Anti-VHD (marcador do vírus da hepatite Delta) e para os pacientes com doença crônica de $84,6 \%$ a $94,7 \%$ de Anti-VHD (BENSABATH et al., 1983, BRAGA et al., 2001).

Aparentemente o vírus apresenta elevada infectividade atingindo especialmente individuos jovens ainda nos primeiros anos de vida. Os pacientes podem evoluir para formas de hepatite fulminantes (Febre Negra de Lábrea) ou formas crônicas, que se associam as características histopatológicas graves no fígado, com curso rápido e progressivo, evoluindo para cirrose, insuficiência hepática e morte (FONSECA et al., 1985; BENSABATH et al., 1987; ANDRADE et al., 1992; FONSECA et al., 1994; BRAGA et al., 2001).

Estudos no estado do Acre, sobre a prevalencia de hepatite B, ainda são incipientes, temos o de VIANA et al. (2005), realizado em doze municípios, de base populacional, que mostra uma prevalência de $\mathrm{HBsAg}$ de $3,3 \%$, perfil de endemicidade intermediária, porém, os dados oficiais disponiveis são os obtidos através da ficha de notificação do SINAN, com 
base no ano de notificação, independente da data do diagnóstico, confirmados segundo os critérios normatizados pelo Ministério da Saúde. Ainda existem subnotificação e limitações na qualidade de informação, segundo o Programa Nacional de Hepatite Virais do Ministério da Saúde, a taxa de deteç̧ão do VHB no Acre em 2000 , foi de 46,7 por 100.000 habitante/ano e em 2009 foi de 111,8 por 100.000 habitante/ano. (SINAN/SVS/MS, 2011).

Mas pode-se observar que dependendo da população estudada, e do marcador sorológico avaliado, a prevalência do VHB no Acre, varia de $54,8 \%$ a $66,1 \%$ para o marcador de contato (anti-HBcTotal) e de $3,3 \%$ a $21,1 \%$ de portadores crônicos (HBsAg), sendo que o sexo masculino, baixa escolaridade, adulto jovem, história de hepatite na família, compartilhamento de escova de dente são fatores importantes (de PAULA et al., 2001; LOBATO et al., 2003a; LOBATO et al., 2003b; VIANA et al., 2005; LOBATO et al., 2006).

A transmissão nesta região ocorre preferencialmente de forma horizontal, predominando a disseminação intradomiciliar, com elevada prevalência de infecção pelo vírus da hepatite $B$ entre os contatos de casos indices principalmente entre os irmãos. A disseminação pode ocorrer através do compartilhamento de objetos de uso pessoal como escova de dente, nos primeiros anos de vida (BRASIL et al., 2003; LOBATO et al., 2006).

Fatores adicionais associados, como aglomeração no domicílio, elevada densidade de artrópodes e freqüentes lesões de pele, contribui para o padrão de hiperendemicidade do VHB e VHD na Amazônia (BRAGA et al., 2001).

De fato, as hepatites assumem proporções alarmantes na Amazônia, com alta taxa de cronificação, evolução para cirrose, carcinoma hepatocelular em adolescente e adulto jovem ((BENSABATH et al., 1987, Galizzi et al., 2010). A mortalidade por hepatite nesta região é cinco a 10 vezes maior do que a média do restante do País (MS-SIM, 2011). (Tabela 2) 
Tabela 2. Taxa de Mortalidade por hepatite viral ${ }^{*}$ no Brasil e no Acre, 20032005.

\begin{tabular}{llcccc}
\hline Ano & & $\begin{array}{c}\text { Virus A } \\
\text { (VHA) }\end{array}$ & $\begin{array}{c}\text { Virus B } \\
\text { (VHB) }\end{array}$ & $\begin{array}{c}\text { Virus C } \\
\text { (NHC) }\end{array}$ & $\begin{array}{c}\text { Virus Delta } \\
\text { (VHD) }\end{array}$ \\
\hline \multirow{2}{2}{2003} & Acre & 0 & 24,4 & 8,14 & 4,88 \\
& Brasil & 0,28 & 2,42 & 5,94 & 0,07 \\
2004 & Acre & 3,26 & 11,40 & 22,79 & 1,63 \\
& Brasil & 0,36 & 2,37 & 7,29 & 0,18 \\
2005 & Acre & 1,5 & 20,9 & 28,4 & 3,0 \\
& Brasil & 0,3 & 4,3 & 8,3 & 0,1 \\
\hline
\end{tabular}

" (por 1 milhão de habitantes/ano)

Fonte: Ministério da Saúde - Secretaria de Vigilância em Saúde

No Brasil, estudos utilizando técnicas mais sensiveis na detecção dos genótipos e subtipos do VHB demonstram haver grande variabilidade genética na distribuição geográfica do vírus com a presença também de genótipos $A, D$ e $G$ em populações antes não suspeitadas sugerindo a influência da afro-descendência e da européia, onde predomina esses genótipos. Nas populações de origem indigena há predomínio do genótipo $\mathrm{F}$ (VIANA et al., 2005, LOBATO et al., 2006, TONETTO et al., 2009; BECKER et al., 2010)

$\mathrm{Na}$ região Sul, o estado de Santa Catarina, entre pacientes e funcionários de um centro de hemodiálise, foi encontrado $31 \%$ de indivíduos com genótipo A; $57 \%$ com genótipo D e $12 \%$ com genótipo $F$ (CARRILHO et al., 2004).

Em São Paulo, REZENDE et al., (2005), avaliaram cinqüenta pacientes com hepatite crônica pelo $\mathrm{VHB}$, sendo identificado o genótipo $D$ em $56 \%$ dos casos, genótipo $\mathrm{A}$ em $41 \%$ e genótipo $\mathrm{F}$ em $2 \%$. Os pacientes que exibiam a mutação pré-core apresentaram maior gravidade de doença hepática, com maiores índices de fibrose e cirrose.

No Acre foram encontrados os genótipos $A, D, G$ e $F$ do VHB e o ll e III do VHD (LOBATO et al., 2006, PARANÁ et al., 2006). O tipo III do VHD tem sido encontrado somente entre os Ameríndios da Bacia Amazônica, (Figura 10).

SOUZA (2008) refere que dependendo do ponto de vista de quem vê a cultura acriana, o Acre não seria o fim do mundo e sim o começo do 
mundo, pois vários povos lá vieram recomeçar suas vidas, assim começou a imigração no final do século XIX, atraídos pela exploração dos seringais no auge do ciclo da borracha, com espanhóis, portugueses, alemãos, síriolibaneses, japoneses, italianos e brasileiros (principalmente nordestinos e da região sul do país), o que poderia explicar essa diversidade de genótipo encontrado nesta região, além dos específicos da região, encontrado principalmente nos indígenas nativos da região (genótipo F do VHB e III do VHD).

Figura 10. Distribuição do vírus da hepatite B e Delta com respectivos qenótipos no Brasil.

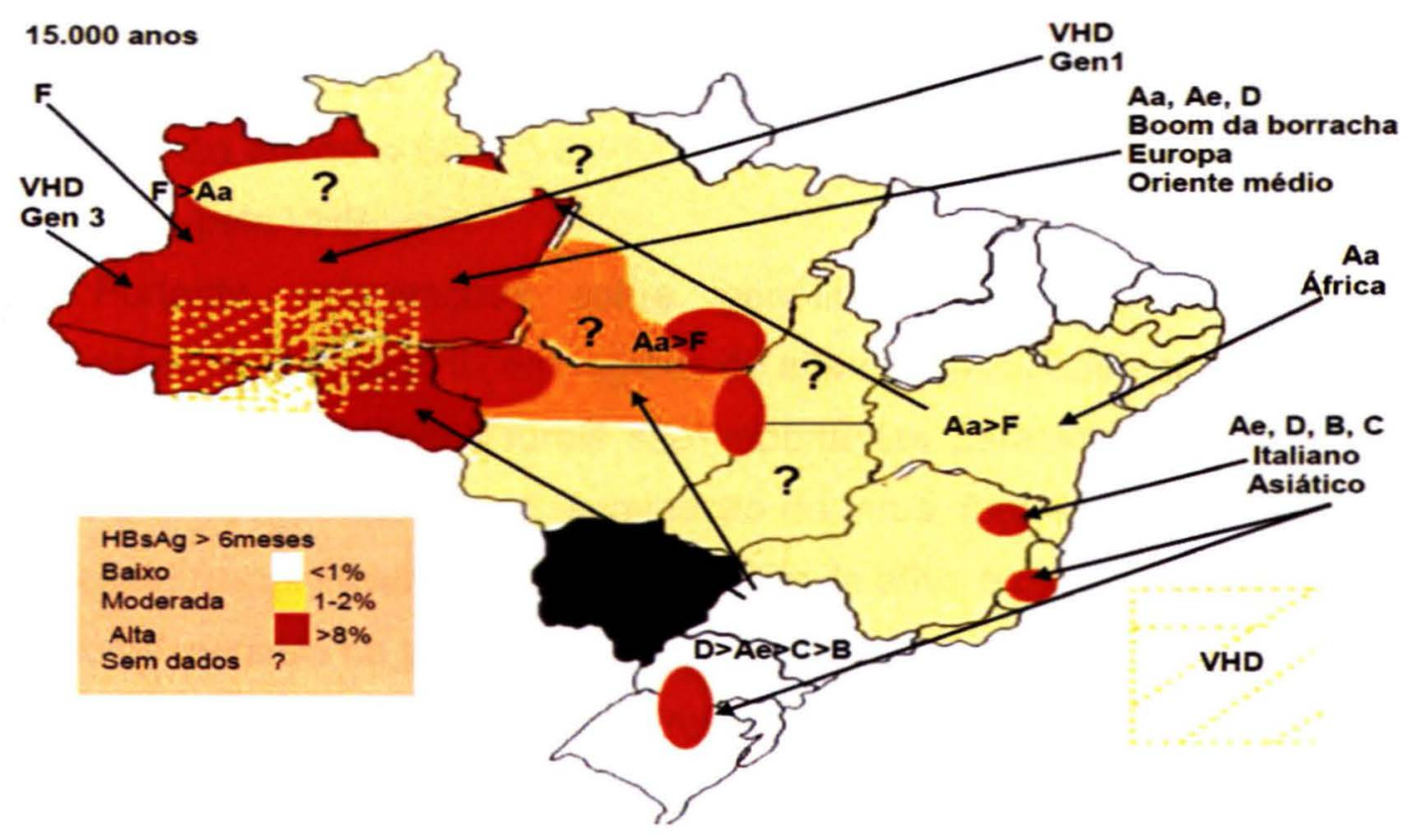

Fonte: Souto, 2008, adaptado

A vacinação teve início no Brasil na década de 80 , no Estado do Amazonas, em 11 municípios endêmicos da Amazônia Ocidental, abrangendo crianças de até nove anos de idade e profissionais de saúde, com três doses de vacina DNA recombinante - que passou a fazer parte do calendário básico de vacinação em todo o Estado do Amazonas, a partir de 1992. Em Lábrea 11 anos após o início da vacinação se observa a redução da prevalência do HBsAg de $15,3 \%$ para $3,3 \%$ na faixa etária de 30 e 50 
anos $(6,1 \%)$, seguida da faixa etária de 15 e 30 anos $(5,2 \%)$ (FONSECA et al., 2002; BRAGA et al., 2004). A partir de 1998, o Programa Nacional de Imunizações (PNI) recomendou a vacinação universal para todas as crianças ao nascimento e em 2001 estendeu para a faixa etária de menores de 20 anos de idade e acima desta idade para os denominados grupos de maior risco, que já estavam incluídos desde 1992 (MS, 2003; SI-PNI, 2008).

$A$ vacinação contra o vírus da hepatite $B$ foi introduzida no Acre na década de 80 , em récem-nascidos e em menores de 15 anos, sendo que em 1999 foi realizada uma campanha de vacinação em massa com cobertura de aproximadamente $100 \%$ da população em todas as faixas etárias. Hoje a cobertura vacinal em menores de um ano fica em torno de $95 \%$, não sendo homogênea em todos os municípios. Já em menores de 20 anos, a cobertura não chega a $60 \%$ (VE-PNI-AC, 2007), o que leva a possibilidade de infecção pelo VHB.

Portanto, informações sobre genótipos, mutantes (diversidade genética) do VHB e do VHD em regiões de alta endemicidade como a região Amazônica e comunidades rurais são importantes para verificar possíveis fatores e risco associados à disseminação do vírus, fatores genéticos virais (mutações) responsáveis pela falha na profilaxia ativa e passiva e auxiliar na adoção de medidas de prevenção e terapêutica.

O Programa Nacional para Prevenção e o Controle das Hepatites Virais (PNHV) foi criado pelo Ministério da Saúde em 2002, o protocolo para tratamento da infecção cronica pelo VHB, remontava desta data. Com o avanço tecnológico e aprovação de novos medicamentos para o tratamento do VHB, os estados com recomendações em protocolos regionais, começaram a adotá-los, independentemente da recomendação do Ministério da Saúde, o que levou a uma oferta de terapia diferenciada entre as diversas regiões. A Sociedade Brasileira de Hepatologia, em 2005 publicou o consenso sobre condutas nas hepatites $\mathrm{B}$ e $\mathrm{C}$ e a Sociedade Brasileira de Infectologia, em 2006 o I Consenso para diagnóstico e manuseio da Hepatite B e (Delta), com base nas recomendações adotadas pelas associaçoes 
internacionais como a Associação Européia para Estudo do Figado (EASL) e a Americana (AASLD), que ainda hoje apresentam controvérsias em relação a quem e quando tratar. Em 27 de Outubro de 2009 foi assinado e publicado em julho de 2010 o Protocolo Clínico e Diretrizes Terapêuticas da Hepatite Cronica B e coinfecções, atualizando o anterior com incorporação de novos medicamentos e orientações para tratamento da infecção cronica pelo VHD (MS/SVS, 2010).

\subsection{VÍRUS DA HEPATITE DELTA}

O vírus da hepatite delta parece ser na região amazônica um dos principais preditores de progressão da hepatite $B$ crônica. Ele é um vírus que causa uma forma severa de hepatite e apresenta-se frequentemente associado com uma rápida progressão da doença. O vírus delta foi descoberto por Rizzeto et al., na década de 1970. É um vírus com características únicas, ou seja, somente causa hepatite na presença do vírus da hepatite B. Esse vírus tem sido isolado somente de humanos, é o menor virus animal, assemelhando-se ao viróide de plantas, quanto a configuração circular do seu genoma (RNA), sua propriedade de auto-clivagem (atividade da ribozima) e a formação do RNA a partir do RNA no ciclo replicativo. Mas existem diferenças importantes, os viróides são menores (250-300 nucleotídeos de comprimento), não requerem um vírus auxiliar e não codificam para uma proteína. Recentemente, foi postulado que o vírus delta possa ter surgido da transcriptosome humana. Pesquisa in vitro com genoma humano para isolar RNAs auto-clivagem revelou várias ribozimas, uma das quais é uma sequência de ribozimas conservadas de mamíferos no gene CPEB3, que pertence a uma familia de genes que regulam a poliadenilação do RNA mensageiro. Esta ribozima é estruturalmente e bioquimicamente relacionada com a ribozima do VHD. A ribozima CPEB3 é encontrado apenas em mamíferos, tanto placentários como marsupiais. A hipótese é que esta ribozima possa ter aparecido há pelo menos 200 milhões de anos atrás, antes que os dois grupos divergissem, postulando-se 
que o VHD surgiu da transcriptoma humana, adquirindo a proteína do antígeno delta e a ribozima auto-clivada do hospedeiro (SALEHI-ASHTIANI et al., 2006).

Com o programa de vacinação universal para o VHB, o uso de seringas descartáveis, triagem em doadores de sangue de $\mathrm{HBsAg}$, e melhorias socioeconômicas levou a um controle da infecção pelo VHB e consequentemente diminuiu a infecção pelo VHD em muitas áreas endêmicas como o Sul da Europa e sudeste da Ásia. Porém, hoje, devido à migração e maiores deslocamento entre regiões este declínio atingiu seu patamar e novos casos de infecção pelo VHD surgem (ERHARDT et al., 2003; DEGERTEKIN et al., 2008; WEDEMEYER\&MANNS, 2010) (Figura 11).

Figura 11. Distribuição do Vírus da hepatite delta no Mundo.

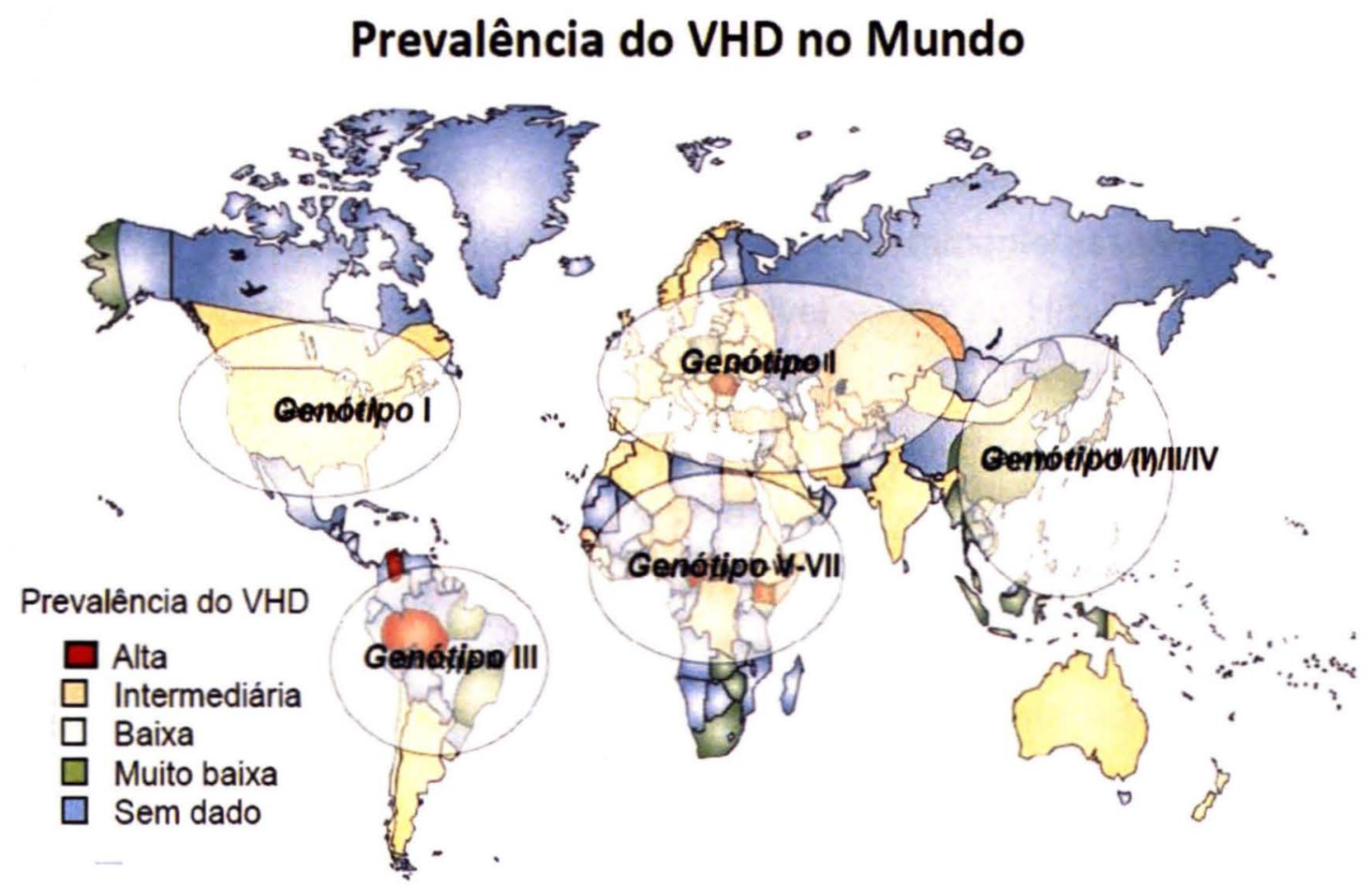

Wedemeyer \& Manns (2010) 
$\mathrm{Na}$ história natural da infecção pelo vírus delta, este pode ser adquirido simultaneamente com o VHB, co-infecção ou infectando um portador crônico do vírus B, super-infecção. A infecção pelo vírus delta geralmente é associado com a supressão do vírus $B$, o que tem sido demonstrado pelo declínio ou desaparecimento do HBcAg no tecido hepático e diminuição dos níveis do HBsAg. A infecção do VHB/VHD está associada a um complexo e dinâmico padrão de dominância viral. A hepatite delta é considerada uma das formas mais severa de hepatite viral humana, com evolução clínica associada à rápida progressão para fibrose com descompensação hepática precoce e maior risco para desenvolvimento de carcinoma hepatocelular, possivelmente relacionada com o genótipo. Conhecimento sobre a patogênese da infecção pelo VHD é limitado. Observaçoes clínicas indicam que a hepatite delta é uma doença imuno mediada, pois sua histologia não difere da histologia dos pacientes com hepatite B ou C. Mas, em outros casos, como o que ocorre no Norte da América do Sul, o VHD teria um efeito citopático, pois apresentam características histológicas incomuns e peculiares, como a presença de células em mórula e o vírus com multiplicação citoplasmática. Importante frisar que o nível de viremia do VHD não está diretamente associado com o estágio da doença hepática, somente o nivel sérico do HBsAg se mostrou fracamente correlacionado com a atividade histológica da doença em pacientes com hepatite delta. Resposta imune celular contra o VHD foram descritas por alguns investigadores, e estes estudos sugerem que a quantidade e a qualidade da resposta da células $T$ do hospedeiro podem ser associadas com o grau de controle da infecção. A variabilidade da gravidade da hepatite pelo vírus delta pode ser um reflexo da variação da resposta imune do hospedeiro ou do vírus delta, levando a uma maior propagação do vírus $B$ nos hepatócitos. Mas como em uma doença imunomediada o vírus delta pode se apresentar de diferentes formas, desde uma doença levemente progressiva a uma de curso progressivo grave com insuficiência hepática aguda e morte no decurso de semanas ou meses. Pode também ocorrer uma rápida progressão para cirrose no prazo de dois anos em $10 \%$ a 
15\% dos pacientes (WU et al., 1990; FATTOVICH et al., 2000; SAGNELLI et al., 2000; RIZZETTO, 2000; JARDI et al., 2001; SU et al., 2006; ROMEO et al., 2009; YURDAYDIN et al., 2010), (Figura 12).

Figura 12. História natural da superinfecção pelo VHD.

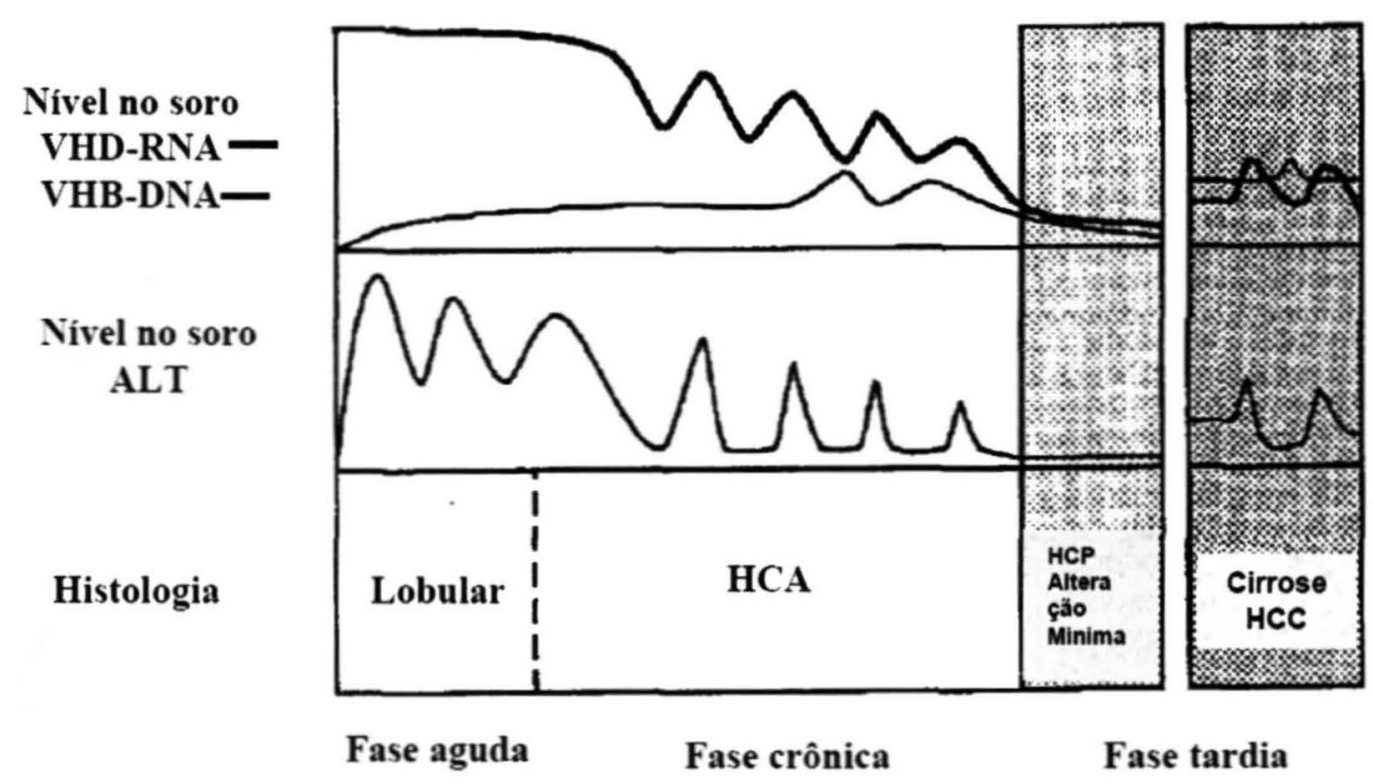

Historia natural da superinfecção pelo VHD: correlação entre a replicação do vírus, nível de ALT e histologia hepática. HCA-Hepatite crônica ativa; HCP- hepatite crônica persistente. Fonte: Wu et al. 1995, adaptado para o português.

Estudos têm demonstrado que o curso clínico da doença não é o mesmo em diferentes regiões, isto pode estar ligado aos diferentes genótipos. Atualmente são oito genótipos do VHD, sendo que o genótipo I se distribui em todo o mundo, com um curso favorável da doença. O genótipo $\mathrm{V}$ a VIII é freqüente na África Central e Ocidental, o genótipo III é observado em países da América do Norte e do Sul, tais como Brasil, Colômbia, Venezuela, Peru e Equador, estando associado a uma doença particularmente grave. O genótipo II e IV é encontrado no Extremo Oriente e associado a uma doença mais leve que o genótipo I (RIZZETTO, 2000; QUINTERO et al., 2001; PARANÁ et al., 2006; SU et al., 2006; YURDAYDIN 
et al. 2010) [Quadro 6]. Recente estudo no Brasil mostrou que a carga viral do VHD é menor em pacientes do genótipo A em comparação com pacientes com genótipo $\mathrm{D}$ ou $\mathrm{F}$ do VHB. Parece que no inicio a rápida progressão da hepatite crônica delta para cirrose está associada com alta replicação do vírus delta (KIESSLICH et al.2009). A infecção pelo VHD aumenta o risco de desenvolvimento de carcinoma hepatocelular e de descompensação hepática (FATTOVICH et al., 2000). Hoje o único medicamento de eficácia comprovada para tratamento da hepatite crônica delta é o interferon (FARCl et al.1994; WEDEMEYER\&MANNS, 2010).

Quadro 6. Relação entre genótipo do VHD, sua distribuição geográfica e clínica

\begin{tabular}{|c|l|l|}
\hline Genótipo VHD & \multicolumn{1}{|c|}{ Países } & \multicolumn{1}{|c|}{ Clínica } \\
\hline I & $\begin{array}{l}\text { Europa, América do Norte (IB), África, Ásia } \\
\text { (IA) }\end{array}$ & Hepatite fulminante \\
\hline II & $\begin{array}{l}\text { Japão, Taiwan, Yakutia (Russia), Taiwan e } \\
\text { Ilha de Okinawa (IIB) }\end{array}$ & $\begin{array}{l}\text { Doença hepática } \\
\text { moderada }\end{array}$ \\
\hline III & $\begin{array}{l}\text { América do Sul (Peru, Colômbia, Venezuela, } \\
\text { Amazônia Ocidental - Acre, Rondônia, } \\
\text { Amazonas) }\end{array}$ & $\begin{array}{l}\text { Hepatite severa - } \\
\text { fulminante }\end{array}$ \\
\hline IV & $\begin{array}{l}\text { Oeste da Africa: Cameron, Guiné, Costa Ivory, } \\
\text { Congo-Brazzaville, Mali }\end{array}$ & \\
\hline V a VIII & África Central e Ocidental & \\
\hline
\end{tabular}

Fonte: Yurdaydin et al, 2010

O Estado do Acre é considerado uma região de média prevalência para infecção pelo VHB, em que o padrão de transmissão é principalmente horizontal numa fase muito precoce da vida (Lobato et al., 2006). A associação com o VHD é freqüente nesta região, com anti-delta IgG variando de $20 \%$ a mais de $50 \%$ em algumas regiões e na população indigena (de PAULA et al., 2001; VIANA et al., 2005; Lobato et al., 2003). A suposta causa desta alta prevalência, não só no Acre, mas na Amazonia Legal, segundo Fonseca (2010), teria sido, o emprego em massa da vacina contra a febre amarela na década de quarenta e cinqüenta, onde utilizaram vacinas derivadas de plasma humano, seringas e agulhas não descartáveis, um dos veículos responsáveis pela disseminação e propagação da infecção pelo VHB e vírus da hepatite D (VHD) nesta população. Outro provável 
veículo de transmissão do VHB na região Amazônica, seria o uso de lancetas não descartáveis para fins de punção digital no diagnóstico da malária.

Na região Amazônica Ocidental brasileira, em especial no Estado do Amazonas, especificamente na calha do Rio Purus, e no Acre, no vale do Juruá, é descrita uma forma atípica de hepatite fulminante há mais de 60 anos. Fonseca (2010) descreve que durante estudos científicos no início da década de 80 , ouviu, dos mais idosos habitantes das calhas dos rios Purus, Solimões e Juruá que tal doença dizimava famílias inteiras nas vilas, povoados e seringais, principalmente na fase do boom da borracha, fim do século XIX e início do século $X X$.

A doença começava abruptamente, o paciente tinha falta de paciência, tristeza e permanecia o tempo todo calado. Em torno de 24 horas, o paciente agitava-se, falando palavras desconexas e de baixo calão, quebrando tudo ao seu redor, mordendo as pessoas, chegando a vomitar o fígado. Após tal quadro, o paciente entrava em coma profundo e, geralmente após 72 horas do início da doença, morria e interessante que, após a morte, o defunto continuava quente por mais de seis horas e sangrando pelo nariz.

O presente estudo tem como objetivo descrever os aspectos epidemiológico, clínico e sorológico e verificar os fatores prognósticos associados à progressão da hepatite B crônica para cirrose na Amazônia Ocidental, Acre, verificando a prevalência da infecção concorrente com o vírus delta e sua associação com as formas clínicas mais graves da doença, principalmente entre os pacientes jovens com quadro avançado da doença, como cirrose descompensada e carcinoma hepatocelular primário.

\subsection{HISTÓRIA DO ACRE: UM ELO PARA ENTENDER AS CARACTERÍSTICAS DA INFECÇÃO PELO VHB E DELTA NO ESTADO.}

O Acre compreende um dos 27 estados brasileiros, localizado na Amazônia Ocidental é $015^{\circ}$ em extensão com $164.221,36 \mathrm{~km}^{2}$, correspondendo $4,26 \%$ da Região Norte, com 707.125 habitantes (IBGE, 
2010). O nome Acre surgiu de "Aquiry", que significa "rio dos jacarés", na língua Apurinã, os habitantes originais da região banhada pelo rio que empresta o nome ao estado. Os primeiros habitantes da região eram os índios, até 1877, quando imigrantes nordestinos vieram para trabalhar nos seringais na extração da borracha.

Neves (2011), através de informações sobre os povos nativos do Acre, descreve que o povoamento do Acre provavelmente começou entre 20.000 e 12.000 anos atrás, quando grupos humanos proveniente da Ásia chegaram à America do Sul. Era o tempo dos grandes animais como o mastodonte, a preguiça gigante (megatherium), que serviam de base alimentar para aqueles povos nômades. "Embora não se tenha vestígios concretos da presença do homem na região durante este período, pode-se imaginar que o homem esteve aqui, junto com os animais que caçava, já que fósseis desses animais são encontrados ainda hoje nos barrancos dos rios acreanos". A partir de 12.000 anos atrás, com as mudanças climáticas e ambientais, mudou também a forma de organização social, os grupos humanos pré-históricos da América começaram a desenvolver as primeiras experiências de domesticação de plantas e animais.

Nas terras baixas da Amazônia, iniciou-se o plantio de raizes, especialmente da mandioca, que se tornaria a base alimentar desses grupos, complementada pela caça, pesca e coleta de frutos e sementes da floresta, que marcou o surgimento, por volta de cinco mil anos atrás, do que foi chamado pelos pesquisadores de "Cultura de Floresta Tropical". Os grupos pré-históricos amazônicos também passaram a fabricar cerâmica e a ocupar certos locais por período mais prolongados.

Dados arqueológicos do Acre, fornecidos por pesquisa realizada na região, nas décadas 70 a 90, mostram que no Acre houve duas grandes tradições ceramistas (Quinari e Acuriá), nos dois maiores vales acreanos (Juruá e Purus) indicando que a diferenciação histórica e cultural da população dos vales do Juruá e Purus é mais antiga do que se pensava. Outra tradição pré-histórica identificada na região são os geoglifos, grandes sítios com formas geométricas e que as primeiras informações mostram que 
os geoglifos parecem guardar alguma relação com as ocorrências arqueológicas do Llano de Mojos, ao norte da Bolivia, reforçando os indícios de contato entre as civilizações andinas e os povos da Amazônia ocidental.

Apesar de haver outros grupos lingüísticos, os grupos indigenas no Acre estão divididos em dois grandes grupos lingüisticos com diferenças significativas: os com predomínio das línguas Aruan e Aruak no Purus e os da língua Pano no vale do Juruá, correspondendo àquelas divisões encontradas pelos arqueólogos nas tradições Quinari e Acuriá.

No início do Século XIX, cada grupo tribal possuía território claramente definido e os relacionamentos entre esses grupos obedeciam às semelhanças étnicas, culturais e as alianças que foram sendo estabelecidas ao longo do tempo. Existem informações que indicam que havia extensas redes de comércio e comunicação cortando os vales acreanos através dos quais eles se comunicavam e trocavam seus produtos. O contato com os não índios trouxe várias doenças para os indígenas, como sarampo, gripe, mas parece que as hepatites já acometiam esta população a mais tempo. Fonseca (2010) reporta a existência, no museu de Porto Velho - Rondônia, de uma urna confeccionada pelos indios Aruak que habitaram esta região no período da descoberta do Brasil, ou seja, há mais de 500 anos atrás. A urna funerária de barro cozido representava um nativo pertencente à família Aruak e revela do ponto de vista médico alguns sinais e estigmas de cirrose hepática, tais como: ascite, umbigo protuso pelo aumento do volume abdominal (hérnia umbilical), ginecomastia e aranhas vasculares. O mesmo interroga se este seria o primeiro registro antropológico sobre a doença cirrose hepática de provável etiologia viral no Brasil.

Outro fato importante, que pode explicar a heterogeneidade das hepatites no estado, está relacionado com a ocupação do Acre pelos não índios, quando por volta de 1878, a borracha era um dos produtos importantes no comércio internacional, com a chegada de brasileiros, principalmente nordestinos, para a exploração da borracha (os "soldados da borracha"), em uma área sem limites definidos com a Bolívia e o Peru. Os brasileiros, juntamente com Galvez, criam então o território independente, o 
Estado Independente do Acre e exigem sua anexação ao Brasil. Em 1899, a Bolívia reconhece como sua esta área, funda Puerto Alonso (Porto Acre) e começa a recolher impostos, com a finalidade de assegurar o domínio das terras, isto com o reconhecimento do governo brasileiro, pelo Tratado de Ayacucho de 1867, que marcava a fronteira entre o Brasil e a Bolívia.

Os brasileiros se revoltam e os conflitos ocorrem. Os seringalistas e seringueiros, organizados por Plácido de Castro, iniciam uma guerra em agosto de 1902 em Xapuri e termina em Puerto Alonso em 17/11/1903 com a assinatura do Tratado de Petrópolis, pelo qual o Brasil recebe a posse definitiva da região em troca de áreas no Mato Grosso, do pagamento de dois milhões de libras esterlinas e do compromisso de construir a estrada de ferro Madeira-Mamoré. Integrado ao Brasil como território, o Acre é subdividido em: Alto Acre, Alto Purus e Alto Juruá, este último desmembrado em 1912 para formar o Alto Tarauacá. Em 1920, foi Unificado e, a partir de 1934, elege representantes para o Congresso Nacional. Foi elevado à categoria de Estado pelo presidente João Goulart em 15/06/1962. Além dos nordestinos, migraram para o Acre: gaúchos, cariocas, espanhóis, italianos e sírio-libaneses.

Com uma população de 733.559 indivíduos, distribuídos nos 22 municípios, divididos em mesorregiões, sendo que a Mesorregião Vale da Acre, compreende a Regional Purus composta dos municipios Manoel Urbano, Santa Rosa do Purus e Sena Madureira; a Regional Baixo Acre composta dos municípios Acrelândia, Bujari, Capixaba, Plácido de Castro, Porto Acre, Senador Guiomard e Rio Branco; Regional Alto Acre composta dos municípios Assis Brasil, Brasiléia, Epitaciolândia e Xapuri, já a Mesorregião Vale do Juruá compreende a Regional Juruá composta dos municipios Cruzeiro do Sul, Mâncio Lima, Marechal Thaumaturgo, Porto Walter e Rodrigues Alves, Regional Tarauacá-Envira composta dos municípios Feijó, Jordão, Tarauacá (IBGE,2010), Figura 13.

A população indígena do Acre, cadastrada no Sistema de Informação de Saúde Indigena (SIASI/FUNASA), em 2007, é de 19.209 indigenas, distribuídos em 167 aldeias localizadas nos municípios de Assis Brasil, 
Cruzeiro do Sul, Feijó, Jordão, Mâncio Lima, Manoel Urbano, Porto Walter, Marechal Thaumaturgo, Santa Rosa do Purus, Sena Madureira, Tarauacá, de etnias diversas entre as quais temos os Jaminawa, Kaxinawá, Manchineri, Arara, Katukina, Yanawá, Kulina, Nawa, Shanenawa, Yauanawá, Nukuni, Poyanawa e Ashaninka, a maioria dos quais já em pleno contato com os brancos. A população ribeirinha tendo como base o ano de 2006 é de 85.385 indivíduos distribuídos ao longo dos rios.

Figura 13. Localização do Estado do Acre na Amazônia Brasileira e regional.

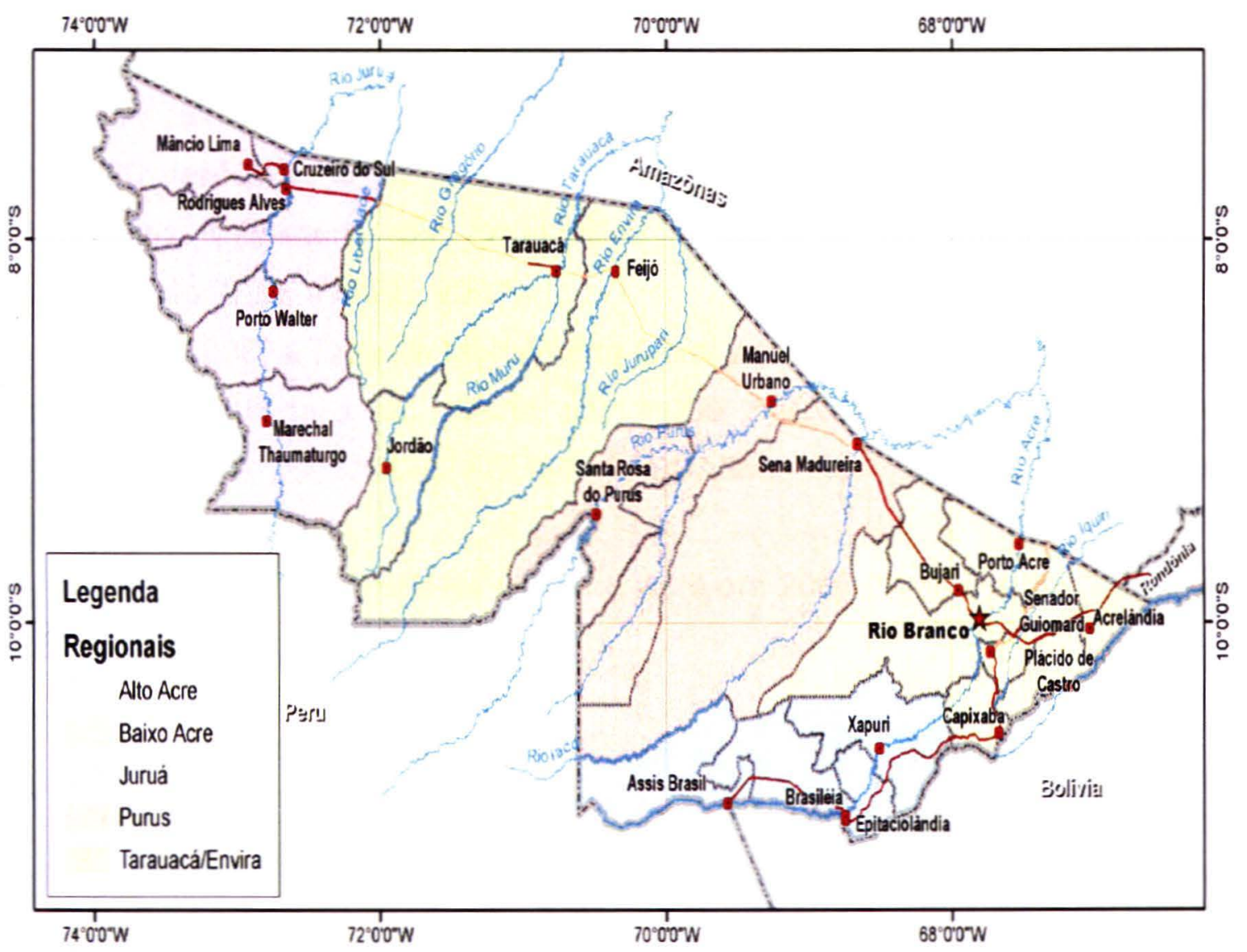

Fonte:SEMA, ZEE-Acre, 2009

O Estado possui $45,7 \%$ de Áreas Naturais Protegidas, divididas em Unidades de Conservação de Proteção Integral e Unidades de Conservação de Uso Sustentável (SEMA, ZEE). 
Em 2008 o Acre possuía uma população economicamente ativa de 328 mil pessoas, com $17,6 \%$ em atividades de agricultura, $39,4 \%$ em serviço público e $32.1 \%$ em atividades de comércio e serviços, com $63 \%$ com renda mensal de até dois salários mínimo (IBGE-PNAD).

O Acre possui um Índice de Desenvolvimento Humano (IDH) de 0,751(PNUD,2008), $17^{\circ}$ posição no ranking brasileiro.

A taxa de analfabetismo no Brasil em 2010 foi de 9,6\%, na região Norte de $11,2 \%$ e no Acre em 2010 foi de $15,4 \%$, sendo as maiores taxas nos municípios de difícil acesso, como Jordão, Porto Walter e Santa Rosa do Purus (Fonte: Pesquisa Nacional por Amostra de Domicílios - PNAD 1992 a 1993, 1995 a 1999 e 2008 a 2009).

A Taxa de Mortalidade Específica por AIDS em 2007, foi de 1,4 por 100.000 habitantes e por doenças transmissiveis foi de 46,2 por 100.000 habitantes (Ministério da Saúde/SVS - Sistema de Informações de Mortalidade (SIM) e IBGE, 2007).

Em 2008, a Taxa de Mortalidade Geral por 1.000 habitantes foi de 4,0, a Taxa de Mortalidade Infantil por 1.000 nascidos vivos foi de 17,9 (Ministério da Saúde/DATASUS/SINASC/SIM, Secretaria Estadual de Saúde).

A taxa de incidência de AIDS no Acre em 2008 foi de 8,4 por 100.000 habitantes. 


\section{HIPÓTESE}

A co-infecção VHD/VHB está associada à evolução para formas graves da hepatite $B$ crônica, levando à cirrose numa fase precoce da vida (antes dos 40 anos de idade). 


\section{OBJETIVOS}

3.1 Descrever as caracteristicas clínicas e epidemiológicas em uma coorte de portadores crônicos do vírus da hepatite $B$, matriculados $e$ atendidos no Serviço de Assistência Especializada de Rio Branco, estado do Acre, entre 2000 e 2009 e seguidos até 2010.

\subsection{Estimar a prevalência de cirrose nesta população}

3.3 Estimar a taxa de incidência por pessoa-ano de cirrose na coorte estudada

3.4 Investigar fatores associados à progressão para cirrose no grupo de portadores crônicos do vírus da hepatite B estudado. 


\section{MATERIAL E MÉTODOS}

\subsection{TIPO DE ESTUDO}

Trata-se de um estudo de coorte retrospectivo de portadores crônicos do vírus da hepatite $B$, matriculados no Serviço de Assistência Especializada-SAE-SESACRE, no período de 2000 a 2009 e acompanhados até 2010.

\section{2 ÁREA DO ESTUdO}

O estudo foi realizado no município de Rio Branco, capital do Estado do Acre, situado na Amazônia Ocidental Brasileira, na região Norte do Brasil. Rio Branco possui cerca de 340 mil habitantes, com taxa de urbanização de $92,73 \%$, e uma população ribeirinha de 5.850 indivíduos. A taxa de analfabetismo em 2000, em Rio Branco, era de 14,0\% e Índice de Desenvolvimento Humano (IDH) de 0,754 (IBGE, 2000). A taxa de mortalidade infantil situava-se em 16,8/1.000 Nascidos Vivos, em 2009. A taxa de mortalidade por hepatite B, em 2009, em Rio Branco foi de $3,3 / 100.000$ habitantes/ano, ou seja, cerca de 10 vezes maior ao do Brasil e seis vezes maior da região Norte, as quais situam- se, respectivamente, em 0,2 e 0,5/100 mil habitantes/ano. A taxa de detecção da infecção crônica do VHB foi de 8,2, 13,6, 107,9 e 104,9/100 mil habitantes/ano no Brasil, Região Norte, Estado do Acre e Rio Branco respectivamente (MSSINAN/SIM/IBGE/2010).

Desde 2007, a organização administrativa dos serviços de saúde do municipio de Rio Branco é composta por uma rede de unidades de saúde distribuída em 13 segmentos ou distritos sanitários. Cada segmento funciona 
como referência para Equipes de Saúde da Família em sua área de abrangência. Possui 53 Unidades de Saúde da Família, com 23 unidades funcionando com equipes completas e 12 centros de saúde. A cobertura do programa saúde da família é estimada em $40 \%$ da população. Dispõe ainda de um Centro de Apoio Diagnóstico (CAD), oferecendo serviços de laboratório, análise clínica e serviço de ultrassonografia (MS/SAS/DAB/IBGE, 2010).

O município de Rio Branco dispõe ainda de duas unidades de atendimento secundário (Unidades de Pronto Atendimento - UPA), o Hospital de Urgência e Emergência (HUERB) e uma unidade de referência de alta complexidade, o Hospital de Clínicas do Acre (HCA), que se integra ao sistema de saúde. Como Rio Branco não dispõe ainda de transplante de fígado, quando os pacientes necessitam desses procedimentos são encaminhados para os grandes centros do Brasil, como São Paulo, Fortaleza e Salvador, através do sistema de Tratamento Fora Domicilio TFD.

Em Rio Branco, à semelhança dos outros municípios do território nacional, o acesso ao diagnóstico e tratamento da hepatite $B$ é universal e gratuito. Até 2009 , os pacientes portadores crônicos do VHB tinham seu diagnóstico e tratamento realizado apenas em Rio Branco, no Laboratório Central (LACEN) ou Hemocentro e SAE, respectivamente. A partir desta data, iniciou-se o processo de descentralização com criação de pólos de atendimento em Cruzeiro do Sul, Tarauacá, estando em implantação em outros municípios, sempre com referência e contra-referência com os serviços locais.

No Município de Rio Branco, de acordo com dados de vigilância, a prevalência é de 93,5/100.000 habitantes/ano de Hepatite $B$, com maior prevalência na faixa etária de 20 a 49 anos, enquanto que a hepatite C atinge mais o grupo etário de 35 a 64 anos, apresentando uma prevalência de 58,8/100.000 habitantes/ano. A capital apresenta cobertura vacinal para hepatite $B$ de $95,1 \%$ em menores de um ano (SEMSA/VE/RB, 2010). 
No Brasil, a imunização contra ○ VHB foi incluída oficialmente somente para recém-nascidos e menores de 15 anos em 1989. Mesmo com esta recomendação, a cobertura vacinal nos 22 municípios do Acre, no período de 1990 a 1998, era inferior a 25\% (DABS/SESACRE/dados não publicados). Frente a esta situação, o governo do Acre, em 1999, junto com a Fundação Nacional de Saúde (FUNASA) e Programa Nacional de Imunização (PNI), efetuou uma campanha de vacinação universal indiscriminada, em todos os municípios do Acre, tanto na zona urbana como na zona rural, com esquema de três doses (0, 1 e 6 meses). Estudo realizado antes da vacinação (TAVARES et al., 2004), na cidade de Rio Branco, mostrou positividade para qualquer um dos marcadores do VHB em $61 \%$ dos indivíduos, sendo que $14,1 \%$ apresentavam somente $\mathrm{o}$ anti-HBs, expressando imunidade pós-vacina. Suscetibilidade foi mostrado em $39 \%$ dos pacientes. Dos pacientes susceptíveis, a soroconversão pós vacina foi de $92 \%$ entre aqueles indivíduos que receberam as três doses e de $67 \%$ entre os que receberam apenas uma dose da vacina. Hoje, a cobertura vacinal em menores de um ano, fica em torno de $85 \%$, não sendo homogênea em todos os municípios, já em menores de 20 anos a cobertura vacinal não chega a $60 \%$ (DABS/VE/PNI-AC, 2009).

\subsection{LOCAL DO ESTUDO}

O presente estudo foi desenvolvido no Serviço de Assistência Especializada/Hospital Dia - SAE/HD, órgão criado em 1990, ligado a Secretaria Estadual de Saúde, funcionando no HCA e desenvolve ações de prevenção e assistência às DST/AIDS e Hepatites e outras doenças infecciosas. É o serviço de referência no Estado do Acre. Atende os pacientes portadores de doenças infecto-contagiosas encaminhadas das Unidades Básicas de Saúde, Programa Saúde da Família, HemoAcre e dos outros municípios do Acre e do Amazonas.

No inicio, a clientela desse serviço era formada principalmente por pacientes com diagnóstico de DST/HIVIAIDS, ocorrendo posteriormente 
ampliação de atendimento para os pacientes portadores de hepatites e outras doenças infecciosas. Em 2006, o serviço começou a ter o registro informatizado e a partir de 2011, temos a introdução do prontuário eletrônico. Este serviço conta atualmente com 12.546 pacientes cadastrados com diferentes diagnósticos. O ambulatório de hepatites foi criado, atendendo os pacientes de todos os estratos socioeconômicos, com quadro de hepatite aguda e crônica, atendendo indivíduos residentes no município de Rio Branco e dos demais 21 municípios do Estado, assim como dos municípios próximo, do estado do Amazonas.

\subsection{POPULAÇÃO DE ESTUDO}

A população de estudo foi formada por pacientes portadores crônicos do vírus da hepatite $B$, matriculados no Serviço de Assistência Especializada no período de Janeiro de 2000 a Dezembro de 2009 e seguidos até 2010.

\subsection{CONCEITO E DEFINIÇOES}

\subsubsection{DEFINIÇÃO DE CASO DE INFECÇÃO CRÔNICA NO ESTUDO}

Foi definido, neste estudo, como caso de infecção crônica pelo vírus da hepatite $\mathrm{B}$, os pacientes com HBsAg positivo por mais de seis meses, de ambos os sexos, independente da idade, co-infectados ou não pelo vírus da hepatite C e ou Delta, com ou sem alterações bioquímicas ou anatomopatológicas, decorrentes da agressão do tecido hepático, matriculados, entre 2000 e 2009, no ambulatório de hepatites do Serviço de Assistência Especializada/ Hospital dia - SAE/HD, do município de Rio Branco, estado do Acre. 


\subsubsection{CONCEITOS}

No âmbito desta pesquisa foram utilizados os seguintes conceitos:

\subsubsection{Infecção pelo vírus da hepatite $B$}

Define-se como infectado pelo vírus $\mathrm{B}$, o indivíduo que apresenta um ou mais dos seguintes marcadores: $\mathrm{HBsAg}$ e AntiHBc total e/ou HBeAg, ou ainda, o VHB DNA positivo por teste que utilize técnicas moleculares.

\subsubsection{Infecção crônica pelo virus da hepatite B}

Paciente apresentando o marcador HBsAg positivo, pela técnica de ELISA, por mais de seis meses, podendo estar em uma das fases clinica descritas a seguir.

\subsubsection{Imunotolerância ao VHB}

Paciente com HBsAg e HBeAg positivo no soro e concomitantemente niveis elevados de VHB-DNA, com aspartato aminotransferase (ALT) e alanino aminotransferase (AST) normais ou próximas do normal e lesão histológica mínima.

\subsubsection{Portador inativo do VHB}

Define-se como portador inativo do VHB aquele que apresenta 0 marcador HBsAg positivo, sem progressão significante da doença necroinflamatória, com transaminases normais ou minimamente elevadas e baixa carga viral (valores inferior $2.000\left(10^{3}-10^{4}\right.$ copias $\left./ \mathrm{ml}\right)$ e $\mathrm{HBeAg}$ negativo/AntiHBeAg positivo.

\subsubsection{Hepatite crônica pelo VHB}


Paciente que apresenta o antígeno de superfície ( $\mathrm{HBsAg}$ ) pela técnica de ELISA por mais de seis meses, com o $\mathrm{HBeAg}$ positivo ( $\mathrm{HC} \mathrm{HBeAg}$ positivo) ou negativo (HC HBeAg negativo), com HBV-DNA sérico positivo, (maior de $2.000 \mathrm{Ul} / \mathrm{ml}\left[10^{4}\right.$ copias $\left./ \mathrm{ml}\right]$ ), com atividade necroinflamatória de moderada a severa, caracterizada por infiltrado inflamatório portal, alterações portais e lesões parenquimatosas com as transaminases persistente ou intermitentemente elevadas.

\subsubsection{Cirrose Hepática}

Quando com resultado da biopsia hepática, apresenta alteração da arquitetura hepática caracterizado ao exame anatomopatológico pela presença de septos fibrosos porta-centro lobulares e porta-porta completos e espessos, os quais delimitam a formação de nódulos parenquimatosos. Foi também confirmado, como caso de cirrose, aquele que apresentasse sinais claros de descompensação clinica e grau de disfunção hepatocelular, como, icterícia, aranhas vasculares, esplenomegalia, circulação colateral abdominal, ascite, eritema palmar, rarefação dos pêlos, ginecomastia, flapping, coagulopatia. E nos exames de imagem apresentassem bordo hepático irregular, diminuição tamanho hepático, dilatação de veia porta e ou esplênica na ultrassonografia, hipertensão portal com varizes de esôfago ou de fundo gástrico na endoscopia.

\subsubsection{Tratamento para hepatite crônica pelo VHB}

O tratamento da infecção crônica pelo VHB ainda tem muitas controvérsias sobre quem e quando tratar, além de ser difícil, de baixa efetividade, prolongado e caro. A indicação tem como base o status do $\mathrm{HBeAg}$, carga viral, idade, fase evolutiva da doença, grau de agressão e inflamação hepática no histopatológico, nível de transaminases e comorbidades. A opção entre um ou outro medicamento também está relacionada à carga viral, genótipo, grau de fibrose e presença ou não de co- 
morbidade. Até outubro de 2009, os estados seguiam protocolos regionais, independentemente da recomendação do Ministério da Saúde, resultando em esquemas terapêuticos e oferta de terapia diferenciada entre as diversas regiões do Brasil. Até então não havia recomendação nacional para o tratamento da infecção crônica pelo VHD. Em outubro de 2009 , foi assinado pelo Ministério da Saúde e publicado em julho de 2010, o Protocolo Clínico e Diretrizes Terapêuticas da Hepatite Crônica B e coinfecções, atualizando o anterior, com incorporação de novos medicamentos e orientações para tratamento da infecção crônica pelo VHD (MS/SVS 2010). A indicação de tratamento segue algoritmo específico para paciente $\mathrm{HBeAg}$ positivo, $\mathrm{HBeAg}$ negativo, cirrótico e portador do VHD, levando em consideração as transaminases, nível de VHB-DNA e histopatológico (Anexo 11).

\subsubsection{TÉCNICAS LABORATORIAIS}

\subsubsection{Testes bioquímicos}

Os testes bioquímicos foram realizados no Laboratório Central de Saúde Publica de Rio Branco (AC), de forma não automatizada até 2007, automatizada pelo Analisador Automático de Bioquímica - Dade Behring Dimension AR a partir de 2008, com valores de referência segundo o método e realizado de acordo com o protocolo sugerido pelo fabricante dos reagentes. (Anexo 8, 9, 10)

Para que houvesse comparabilidade na interpretação dos exames, os resultados foram divididos pelo limite superior de normalidade de cada exame. Por exemplo, para os pacientes que tiveram sua primeira consulta de 2000 a 2007 os valores das transaminase foram divididos pelo limite superior de normalidade para aquele período, ou seja, para o ALT o valor de 20 e para o AST o valor de 18 e para aqueles com primeira consulta em 2008 e 2009 os valores foram divididos pelo limite superior da normalidade para esta época, ou seja, o valor de 65 para o ALT e 37 para o AST, sendo que $o$ resultado foi expresso em quantas vezes às enzimas estavam 
aumentadas em relação ao limite superior do valor normal (LSN). O mesmo se procedeu para as outras enzimas analisadas. As plaquetas o valor de normalidade para todo o período foi maior ou igual a $150 \times 10 \mathrm{~mm}^{3}$. Para os valores dos últimos exames, foi feito o mesmo procedimento, de acordo com o valor de referência na época.

\subsubsection{Teste imunológico e molecular}

Os exames imunológicos para a pesquisa dos marcadores do vírus da hepatite $B$ foram realizados no Laboratório Central (LACEN - Ac), usando Kits comerciais (ABBOTT, Roche Diagnostic ou Sanofi-Pasteur) seguindo-se as instruções do fabricante.

O DNA do VHB foi pesquisado pelo método do PCR em tempo real quantitativo, utilizando-se kits comerciais do laboratório Roche $\AA$ (AMPLICOR HBV MONITOR ${ }^{\mathrm{TM}}$ ), que utiliza a PCR para amplificação e hibridização do DNA.

\subsubsection{Análise histológica}

Os exames histológicos dos espécimes extraídos de biópsias hepáticas foram avaliados no Departamento de Patologia do Hospital Fundação do Acre (FUNDHACRE), com revisão de lâmina no serviço da Fiocruz em Salvador-Bahia. O escore Metavir (BEDOSSA et al 1994, DEGOS et al., 1998) foi utilizado para estadiamento da doença no portador crônico do vírus da hepatite $B$ associado ou não ao vírus delta e ou C. As lâminas de biópsia hepática foram coradas com hematoxilina/eosina, picrosirius, reticulina e coloração de Perls. 


\subsection{CRITÉRIOS DE INCLUSÃO}

Pacientes que cumprem a definição de caso de hepatite crônica pelo vírus $B$ estabelecida pelo estudo e que foram acompanhados regularmente por um período mínimo de um ano e submetidos a exames físicos e laboratoriais (bioquímico e sorológico), com os respectivos resultados registrados em prontuário. Os pacientes incluídos concordaram em participar do estudo e, após serem devidamente informados a respeito da pesquisa, assinaram o Termo de Consentimento. Em relação aos pacientes que não foram localizados, foi assinado o Termo de isenção do TCLE.

\subsection{CRITÉRIOS DE EXCLUSÃO}

Foram excluídos os pacientes com as seguintes características: 1) os que apresentavam anticorpos anti-HBc Total na ausência dos demais marcadores; 2) os que apresentaram durante o seguimento anticorpos AntiHBcTotal e Anti-HBs positivos, 3) os pacientes com diagnóstico de hemocromatose, doença de Wilson e hepatite auto-imune, 4) pacientes com hepatocarcinoma; 5) os pacientes com co-infecção com HIV; 5) os que não permitiram coleta de amostra biológica e não assinaram o TCLE; 6 ) os que tinham apenas uma consulta e não possuiam os exames laboratoriais indispensáveis para análise proposta pela pesquisa; 7) os que não apresentavam dados completos que permitissem a confirmação do caso; 8) e os que haviam evoluído para óbitos por outras causas.

\subsection{FONTE DE DADOS}

Os dados utilizados nessa pesquisa tiveram como fonte os prontuários dos pacientes disponíveis do Serviço de Arquivo Medico (SAME) e complementados por questionário estruturado (Apêndice 2) aplicado pela pesquisadora no período final de acompanhamento, de Outubro de 2008 a dezembro de 2009. 


\subsection{PROCEDIMENTO DE SELEÇÃO DA POPULAÇÃo DO ESTUDO}

Após revisão dos prontuários no SAME do serviço foram identificados 5.697 pacientes cadastrados no ambulatório de hepatites do SAE com diagnóstico de hepatopatia crônica de diferentes etiologias. Em seguida, digitaram-se os dados desses pacientes em uma planilha do Excel e na seqüência aplicando os critérios estabelecidos pela pesquisa, selecionaramse 772 com diagnóstico de infecção crônica pelo VHB, que cumpriam os critérios de inclusão deste estudo, sendo que 100/772 (13,0\%) foram excluidos, por não permitirem a coleta de amostra biológica ou não assinaram o Termo de Consentimento. Foram incluidos 672 pacientes (Figura 14).

Figura 14. Número de pacientes cadastrados no ambulatório de hepatites do SAE, com diagnóstico de hepatopatia crônica até dezembro de 2009.

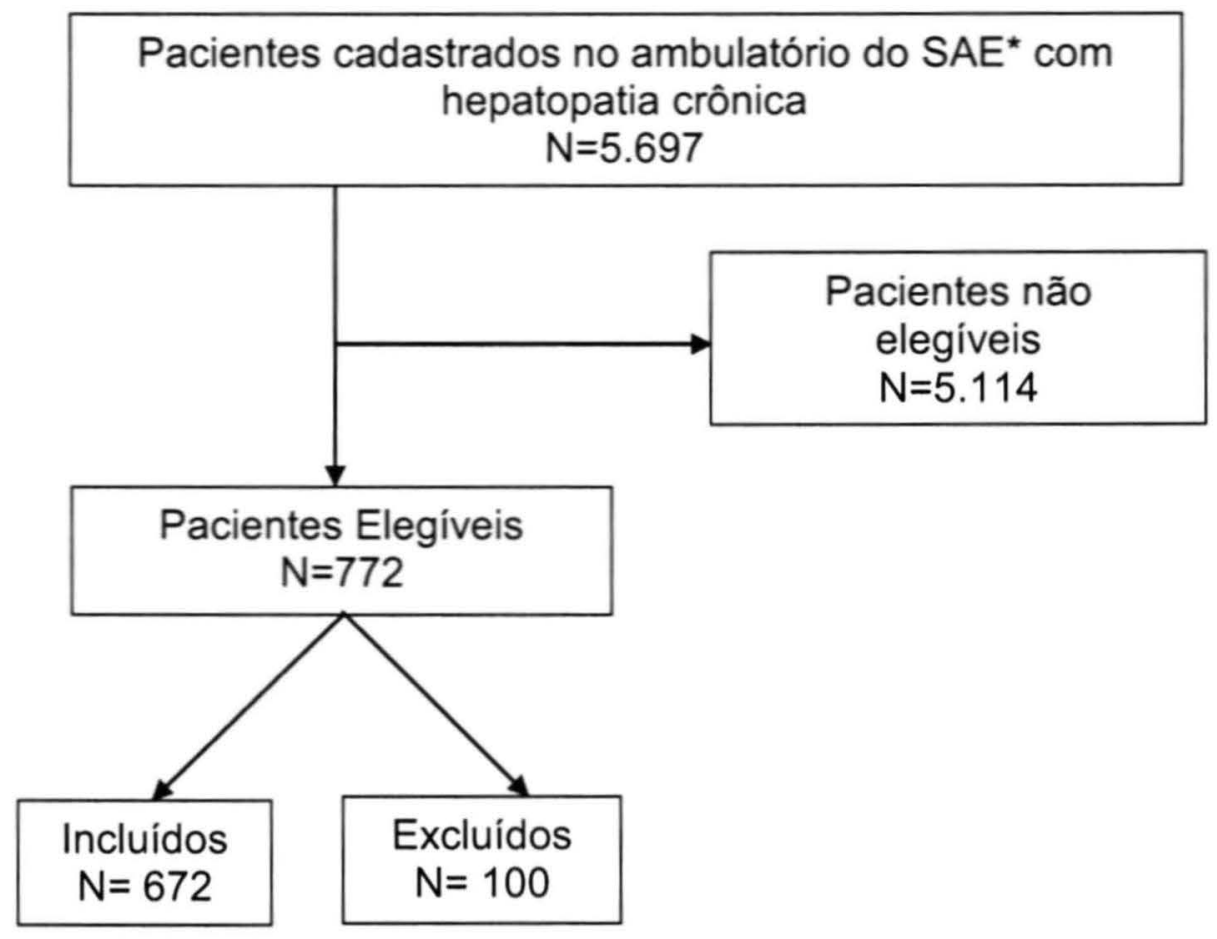

* SAE: Serviço de Assistência Especializada 


\subsection{VARIÁVEIS DO ESTUDO}

As variáveis de estudo são as sócio-demográficas (idade, sexo, raça/etnia, local de nascimento, procedência, escolaridade); características epidemiológicas (possiveis formas de transmissão, história pregressa de vacinação contra o VHB), aspectos clínicos (fase da doença, co-infecção com VHD, HCV) e laboratoriais (exames bioquímicos, sorológicos, moleculares, histopatológicos).

\subsection{CRIAÇÃO DO BANCO DE DADOS E INSTRUMENTOS DE COLETA DE DADOS}

Após a seleção dos pacientes incluídos no estudo, os dados foram digitados no programa Excell 2007, o qual, em seguida, foi convertido para o programa estatístico SPSS versão 15. Previamente, ao início da análise, foi efetuada uma análise de consistência dos dados.

\subsection{ANÁLISE DOS DADOS}

Inicialmente foi realizada uma análise descritiva das características dos pacientes com infecção crônica hepatite $B$, no momento do ingresso no estudo, quanto às características sociodemográficas e epidemiológicas. Foram observadas as distribuições das variáveis categóricas e contínuas, para estas últimas, foram apresentadas as médias e desvio padrão. Os dados foram apresentados de acordo com o uso de tratamento; mono ou dupla infecção e dos casos com e sem desfecho para cirrose.

A incidência de cirrose, na população estudada, foi estimada tomando-se como numerador os casos de cirrose e, como denominador, o total de pessoa-tempo em risco para o evento em anos.

A incidência de cirrose entre os pacientes tratados foi estimada tomando-se como numerador os casos de cirrose entre os tratados e como 
denominador, o total de pessoa-tempo tratado em risco para o evento em anos.

A incidência de cirrose entre os pacientes não tratados foi estimada, tomando como numerador os casos de cirrose entre os não tratados e, como denominador, o total de pessoa-tempo não tratado em risco para o evento em anos.

As variáveis clínicas, ultrassonograficas e laboratoriais foram avaliados em dois momentos, no inicio e no final do seguimento, sendo que naqueles que evoluíram para cirrose, o final do seguimento foi o momento do diagnóstico da cirrose.

Para comparação das proporções dos pacientes que evoluíram para cirrose dos que não evoluíram, aplicaram-se os testes do qui-quadrado de Pearson e o exato de Fischer para as variáveis categóricas, e para variáveis contínuas o teste Kruskal-Wallis.

$\mathrm{Na}$ investigação de fatores associados à evolução grave da hepatite crônica $B$, tomamos a evolução para cirrose hepática como variável dependente e, como variáveis independentes, as exposições de interesse. Com essa finalidade utilizamos a regressão logística condicional para as estimativas das odds ratio não ajustadas e ajustadas com os respectivos $95 \%$ do intervalo de confiança $\left(I_{95 \%}\right)$. Incluímos no modelo final, as variáveis de relevância biológica e que apresentaram $P<0,20$ nas análises bivariadas. Este modelo foi ajustado por procedimento progressivo passo-apasso, com inclusão das variáveis seguindo uma ordem crescente dos valores de OR. Avaliamos a importância das variáveis para o modelo final, através do teste da razão de verossimilhança, considerando significante para $p \leq 0,05$. Para a análise utilizamos os programas estatísticos SPSS versão 15 e o STATA versão 9.0 .

\subsection{ASPECTOS ÉTICOS DA PESQUISA}

Esta pesquisa atende as recomendações da Resolução $n^{\circ} 196$ de 10/10/96, do Conselho Nacional de Saúde para Pesquisa Científica em 
Seres Humanos. O estudo foi fundamentado em análise de dados obtidos nos prontuários e entrevistas com os pacientes atendidos no Ambulatório de Hepatites do Serviço de Assistência Especializada da Secretaria de Saúde do Estado do Acre. Nenhuma informação que permita identificar as pessoas incluídas no estudo será divulgada, de forma a garantir a privacidade e a confidencialidade das informações e o anonimato dos sujeitos da pesquisa, utilizando-se os dados exclusivamente para os propósitos da pesquisa. Os pesquisadores assumem também a responsabilidade de divulgar o resultado da presente pesquisa aos setores interessados, assim como em publicações cientificas da área. Foi obtido o consentimento informado de cada um dos pacientes que aceitaram participar da pesquisa e assinado, pelo pesquisador, o termo de isenção do TCLE para aqueles pacientes que não foram localizados, após várias tentativas e que foram utilizados os dados dos prontuários.

Esta pesquisa foi aprovada pelo Comitê de Ética em Pesquisa (CEP) do Hospital de Clínicas do Acre (HCA) (parecer número 156/2008) e pelo CEP da Faculdade de Saúde Pública da USP (protocolo 1867/2008), (Anexo $12,13)$ 


\section{RESULTADOS}

\subsection{FORMAÇÃO DA COORTE ESTUDADA}

Dos 5886 pacientes cadastrados no Serviço de Assistência Especializada com diagnóstico de hepatopatia crônica, 38,1\% (2245/5886) apresentava o marcador HBsAg positivo, 22,6\% (1330/5886) deles anticorpos para hepatite C positivo (AntiVHC), 18,4\% (1082/5886) possuia antiHBcTotal positivo, 3,2\% (188/5886) tinha antiHAV IgM positivo, 9,8\% (577/5886) cirrose com várias etiologias, 4,1\% (240/5886) com antiHBs sem outros marcadores (imunidade pós vacina) e 3,8\% (224/5886) com diagnóstico de outras hepatopatias.

Portadores crônicos do VHB sem cirrose ou carcinoma hepatocelular no momento de sua inclusão no estudo, com um ano ou mais de acompanhamento totalizaram 772 pacientes. Desse total foram excluidos 13,0\% (100/772), por não concordarem em participar. As características dos dois grupos estão apresentadas na Tabela 3 , não sendo observada diferença entre o grupo excluído e o total selecionado, quanto a sexo $(p=0,25)$, idade na primeira consulta $(p=0,07)$, tempo de acompanhamento $(p=0,94)$ e co-infecção com o VHD $(p=0,09)$ e VHC $(p=0,53)$. 
Tabela 3. Características dos pacientes portadores crônicos do vírus da hepatite $B$, selecionados para o estudo que cumpriam ou não os critérios estabelecidos por esta pesquisa, cadastrados no serviço de Assistência Especializada de 2000 a 2009, Rio Branco, Acre.

\begin{tabular}{|c|c|c|c|c|}
\hline & $\begin{array}{c}\text { Excluídos } \\
n-100(13,0 \%)\end{array}$ & $\begin{array}{c}\text { Incluidos } \\
\text { n-672(87,0\%) }\end{array}$ & $\begin{array}{c}\text { Total } \\
\mathrm{n}-772(100) \\
\end{array}$ & \\
\hline Caracteristicas & $\mathbf{N}(\%)$ & $\mathbf{N}(\%)$ & $\begin{array}{c}\mathrm{N} \\
(\%) \\
\end{array}$ & $\mathbf{p}$ \\
\hline $\begin{array}{l}\text { Sexo } \\
\text { Masculino } \\
\text { Femenino }\end{array}$ & $\begin{array}{l}59(59,0) \\
41(41,0)\end{array}$ & $\begin{array}{l}369(54,9) \\
303(45,1)\end{array}$ & $\begin{array}{l}428(55,4) \\
344(44,6)\end{array}$ & 0,255 \\
\hline $\begin{array}{l}\text { Idade/primeira consulta } \\
0-14 \text { anos } \\
15-29 \text { anos } \\
30-39 \text { anos } \\
40-49 \text { anos } \\
\geq 50 \text { anos } \\
\text { Média de idade (DP) } \\
\text { Mediana } \\
\text { Min/Max }\end{array}$ & $\begin{array}{c}2(2,0) \\
35(35,0) \\
26(26,0) \\
16(16,0) \\
21(21,0) \\
35,7( \pm 14,1) \\
33,0 \\
0 / 71\end{array}$ & $\begin{array}{c}30(4,5) \\
251(37,4) \\
173(25,7) \\
141(21,0) \\
77(11,5) \\
33,3( \pm 12,7) \\
32,0 \\
1 / 73\end{array}$ & $\begin{array}{c}32(4,1) \\
286(37,0) \\
199(25,8) \\
157(20,3) \\
98(12,7) \\
33,7( \pm 12,9) \\
32,0 \\
0 / 73\end{array}$ & 0,074 \\
\hline $\begin{array}{l}\text { Tempo/acompanhamento } \\
1 \text { ano } \\
2 \text { anos } \\
3-4 \text { anos } \\
\geq 5 \text { anos } \\
\text { Média de tempo (DP) } \\
\text { Mediana } \\
\text { Min/Max }\end{array}$ & $\begin{array}{c}29(29,0) \\
17(17,0) \\
31(31,0) \\
23(23,0) \\
3,2( \pm 2,1) \\
3,0 \\
1 / 9\end{array}$ & $\begin{array}{c}232(34,5) \\
90(13,4) \\
152(22,6) \\
198(29,5) \\
3,4( \pm 2,5) \\
3,0 \\
1 / 10\end{array}$ & $\begin{array}{c}261(33,8) \\
107(13,9) \\
183(23,7) \\
221(28,6) \\
3,33( \pm 2,4) \\
3,0 \\
1 / 10\end{array}$ & 0,941 \\
\hline $\begin{array}{l}\text { Co-infecção VHD* } \\
\text { Não } \\
\text { Sim }\end{array}$ & $\begin{array}{l}82(82,8) \\
17(17,2)\end{array}$ & $\begin{array}{l}474(76,3) \\
147(23,7)\end{array}$ & $\begin{array}{l}556(77,2) \\
164(22,8)\end{array}$ & 0,094 \\
\hline $\begin{array}{l}\text { Co-infecção VHC** } \\
\text { Não } \\
\text { Sim }\end{array}$ & $\begin{array}{c}97(97,0) \\
3(3,0)\end{array}$ & $\begin{array}{c}614(97,3) \\
17(2,7)\end{array}$ & $\begin{array}{c}711(97,3) \\
20(2,7)\end{array}$ & 0,530 \\
\hline
\end{tabular}

Numero de pacientes sem dados para esta variável: *vírus da hepatite delta-52 pacientes; **vírus da hepatite C-41 pacientes.

\subsection{RESULTADOS DA COORTE DE PORTADORES DO VHB}

5.2.1 Descrição das características dos indivíduos portadores crônicos do VHB sem cirrose à entrada do estudo

Dos 672 pacientes efetivamente estudados, em 87,5\% (588/672) deles o diagnóstico sorológico foi realizado no Laboratório Central de Rio Branco (LACEN), 6,7\% (45/672) no Hemoacre com confirmação posterior no 
LACEN, enquanto que, 5,8\% (39/672) tiveram seu diagnóstico sorológico em outros serviços como o Laboratório de Fronteira e laboratórios particulares.

Do total de pacientes acompanhados 44,5\% (299/672) foram encaminhados por outros serviços ao Serviço de Assistência Especializada foram, sendo que a regional do Purus, do Juruá e Baixo Acre contribuíram com o maior número de pacientes $(12,1 \%, 4,9 \%$ e $10,4 \%)$ respectivamente. Em Rio Branco, os 373 pacientes foram encaminhados dos centros de saúde, módulo de saúde da família e do Hemoacre.

Com referência às características sócio-demográficas, $77,1 \%$ (518/672) deles relatou ter nascido no estado do Acre, 55,5\% (373/672) tinha como procedência o município de Rio Branco; 70,7\% (475/672) se autodenominava pardo, 20,1\% (135/672) brancos, 6,3\% (42/672) negros e $3,0 \%(20 / 672)$ indígenas; $65,3 \%(385 / 590)$ dos pacientes tinham até oito anos de estudo, 25,6\% (172/672) tinham como profissão do lar e 12,1\% (81/672) eram agricultores, enquanto que 63,4\% (419/672) referiam profissões diversas, como estudantes, pedreiro, funcionário público, autônomo e outras; $62,8 \%$ (404/644) relatavam união estável, com 42,1\% (271) casados.

Quanto ao provável modo de contágio, em 8,2\% (55/672) dos pacientes não se conseguiu identificar-lo, 85,5\% (575/672) relataram apenas um modo possível de contágio e 6,3\% (42/672) tinha dois ou três prováveis forma de contágio. O mais relatado foi o intra-familiar abrangendo $70,8 \%$ (476/672) dos pacientes, com relato de pelo menos um membro da familia portador do vírus B, seguida do parenteral 20,5\% (138/672). (Gráfico 1). 
Figura 15. Possível modo de contágio dos portadores crônico do vírus da hepatite B acompanhados no Serviço de Assistência Especializada, 2000 a 2009. Rio Branco, Acre, Brasil.

\section{Possível modo de contágio $\underset{8,2 \%}{\stackrel{\text { Indeterminado }}{8}}$}

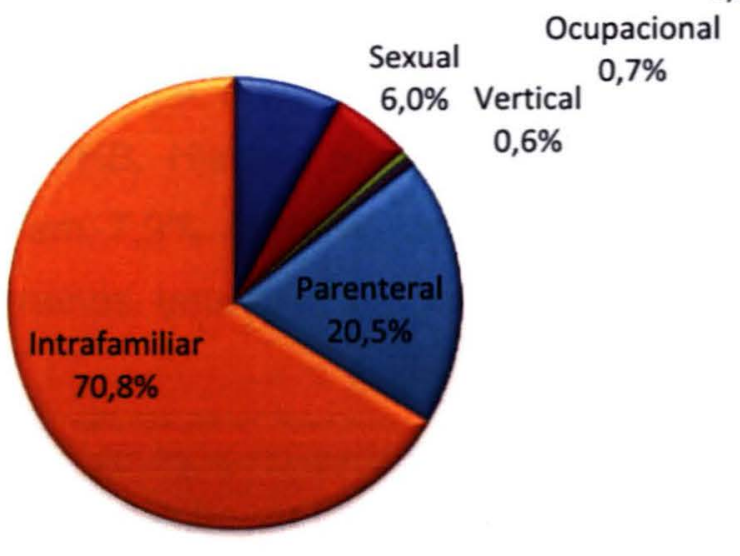

OBS. $6,3 \%(42 / 672)$ pacientes tinham mais de uma possivel forma de contágio.

Em relação ao tipo de exposição, foi relatado por 86,6\% (582/672) dos pacientes, sendo que 7,5\%( 43/577) relatavam apenas um tipo de exposição, enquanto que 10,9\% (63/577), 28,4\% (164/577); 26,2\%(151/577); $17,9(103 / 577)$ e $9,2 \%(53 / 577)$ referiam dois, três, quatro, cinco e seis ou mais tipos de exposição, respectivamente. Os tipos mais frequentes de exposição foram: 78,8\% (451/572) compartilhamento de objetos cortantes, $49,6 \%$ (284/573) compartilhamento de escova de dente, 39,5\% (223/564) uso de seringa de vidro, 7,3\% (80/565) transfusão de sangue, - dos quais $60 \%(48 / 80)$ tinha sido realizado há mais de 10 anos -, em 39,7\% (250/630) dos pacientes foi relatado cirurgia, dos quais, 47,2\% (118/250) há mais de 10 anos $(47,2 \%)$, finalmente, em $89,5 \%$ (513/573) dos pacientes houve relato de tratamento dentário (Gráfico 2).

História de uso de drogas ilícitas foi relatado em 4,0\% (25/629), 1,9\% (12/628) e $0,8 \%$ (5/628) para droga fumada, inalada e injetável, respectivamente. A história de vacina contra o VHB foi relatado em $66,1 \%$ (366/564) desta população, com 52,7\% (193/366) dos pacientes com o 
esquema vacinal completo. Mais de $70 \%$ informaram terem sido vacinados na campanha de vacinação que ocorreu no Estado do Acre, em 1999.

Vida sexualmente ativa foi relatada em 95,1\% (639/672) dos pacientes e $72,3 \%(353 / 567)$ dos pacientes referiam que não usavam camisinha ou usavam às vezes. 9,7\% (50/514) dos pacientes tinham parceiro portador do VHB e $8,3 \%$ (44/532) relatavam contato sexual no passado com portador do VHB. História anterior de doença sexualmente transmissivel foi relatado em 7,9\% (42/534) dos pacientes. A história de ingestão de álcool pelo menos uma vez na vida foi relatada em $55,6 \%$ (330/594).

Figura 16. Provável tipo de exposição ao vírus da hepatite $\mathrm{B}$ dos portadores crônico do vírus da hepatite $B$ acompanhados no Serviço de Assistência Especializada, 2000 a 2009. Rio Branco, Acre, Brasil.

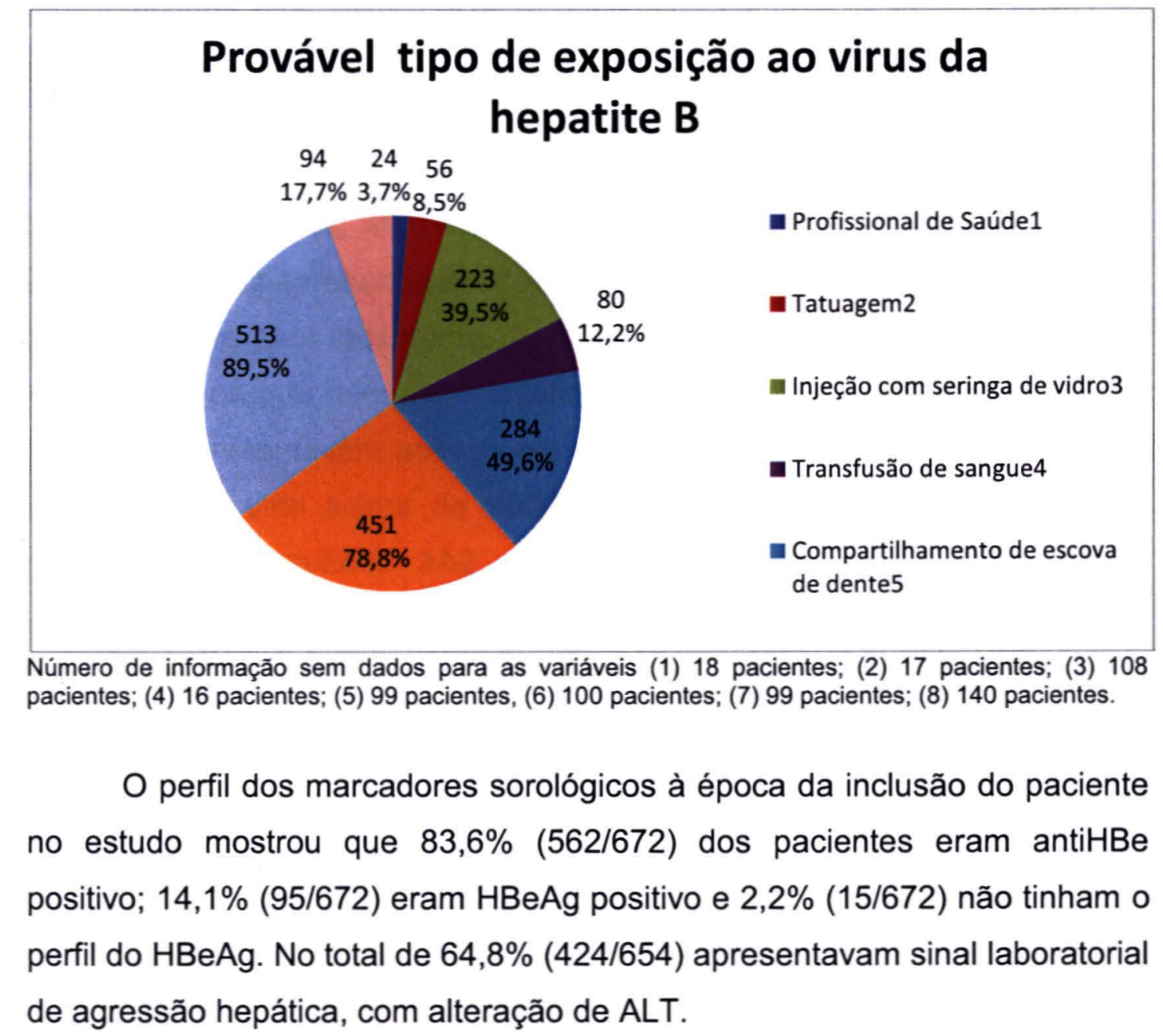


Dos 672 pacientes, 92,0\% (618) realizaram pelo menos uma ultrassonografia abdominal, sendo que 33,5\% (207/618) apresentava pelo menos uma alteração. As principais alterações encontradas foram, 7,3\% (45/618) hepatomegalia, 9,2\%(57/618) esplenomegalia, 6,6\% (41/618) esteatose, $21,4 \%(132 / 618)$ textura hepática heterogênea, $0,6 \%(4 / 618)$ fígado diminuído. No final do seguimento, 366 dos 672 pacientes $(54,5 \%)$ incluídos no estudo submeteram-se a nova ultrassonografia, dos quais $45,6 \%(167 / 366)$ apresentaram-na alterada. As principais alterações foram: $7,4 \%(27 / 366)$ de hepatomegalia; 16,7\% (61/366) de esplenomegalia, 10,1\% $(37 / 366)$ de esteatose, $37,4 \%$ (137/366) fígado com textura heterogênea, $9,3 \%(34 / 366)$ com dilatação de veia porta e ou esplênica, $6,3 \%(23 / 366)$ fígado diminuído, 4,4\% (16/366) nódulo hepático, 2,5\%(9/366) ascite.

Segundo o protocolo estadual, vigente na época, teriam indicação de tratamento àqueles pacientes que cumprissem um ou mais dos seguintes critérios: alteração de transaminases, biopsia hepática apresentando inflamação $\geq A 2$ e ou fibrose $\geq F 2$ ou carga viral $\geq 2000 U \mathrm{l} / \mathrm{ml}$. Ao verificar os critérios para tratamento, constatou-se que 24,7\% (166/672) não cumpriam nenhum dos critérios, 46,0\% (309/672) apresentavam apenas um critério, $22,6 \%$ (152/672) apresentavam dois critérios e 6,7\% (45/672) apresentavam os três critérios para tratamento.

Entre os que cumpriam critérios de indicação de tratamento, 35,7\% (240/672) apresentavam apenas alteração de transaminase, 8,9\% (60/672) apenas carga viral acima de $2000 \mathrm{Ul} / \mathrm{ml}, 1,2 \%$ (8/672) apenas a biopsia hepática com resultado $\geq A 2$ e ou $\geq F 2,6,7 \%$ (45/672) alteração de transaminase e de biopsia hepática ( $\geq A 2$ e ou $\geq F 2$ ), 14,0\% (94/672) transaminase alterada e carga viral > 2000Ul/ml, 2,1\% (14/672) carga viral > $2000 \mathrm{Ul} / \mathrm{ml}$ e biopsia hepática $\geq A 2$ e ou $\geq F 2,6,7 \%$ (45/672) alteração de transaminase, carga viral > 2000Ul/ml e biopsia hepática com histopatológico $\geq A 2$ e ou $\geq F 2$. 
5.2.2 Descrição das características dos indivíduos portadores crônicos do VHB sem cirrose à entrada do estudo, segundo história de tratamento

Os pacientes foram divididos em três grupos, de acordo com a história de tratamento, o primeiro grupo com os pacientes sem indicação de tratamento $24,6 \%$ (165/672), o segundo grupo com os pacientes que tinham indicação de tratamento e foram tratados 13,2\% (89/672) e o terceiro grupo com os pacientes com indicação de tratamento e que não foram tratados $62,2 \%(418 / 672)$. As características dos grupos são apresentadas na Tabela 4.

Analisando $\circ$ total de pacientes pôde-se verificar que houve maior proporção do sexo feminino ( $54,9 \%$ versus $45,1 \%)$, embora não se observe diferença entre os grupos. Entre os pacientes tratados, o sexo masculino foi em maior proporção ( $60,7 \%$ versus $35,2 \%$ versus $45,7 \% p=0,08)$.

A mediana de idade ao diagnóstico no grupo como um todo foi de $32 \pm 12,7$ anos, variando de menos de um ano a 73 anos, sendo que no grupo dos pacientes tratados a mediana foi a menor dos três grupos $(29 \pm 12,4$ anos, variando de 5 a 56 anos). Em relação à distribuição por grupo etário $4,9 \%(33 / 672)$ tinham até 14 anos, 39,3\% (264/672) de 15 a 29 anos, 25,1\% (169/672) de 30 a 39 anos, $20,5 \%(138 / 672)$ de 40 a 49 anos e $10,1 \%$ (68/672) 50 anos ou mais.

$\mathrm{Na}$ primeira consulta a mediana de idade no grupo geral foi de 32 $\pm 12,7$ anos, variando de 1 a 73 anos, tendo o grupo tratado a menor mediana de idade na primeira consulta $(31 \pm 12,7$ variando de 6 a 56 anos).

Quanto ao tempo de acompanhamento o grupo como um todo teve mediana $3 \pm 2,5$ anos, porém $\circ$ grupo de paciente tratado foi $\circ$ que apresentou a maior mediana de tempo de acompanhamento $(5 \pm 2,3$ anos $p<0,0001)$. 
Tabela 4. Características sociodemográficas dos portadores crônico do vírus da hepatite $B$, segundo história de tratamento. Serviço de Assistência Especializada, 2000 a 2010. Rio Branco, Acre, Brasil.

\begin{tabular}{|c|c|c|c|c|c|}
\hline \multirow{3}{*}{ Características } & \multicolumn{3}{|c|}{ Tratamento } & \multirow[b]{2}{*}{ Total } & \multirow[b]{3}{*}{$\mathbf{p}$} \\
\hline & $\begin{array}{c}\text { Sem } \\
\text { indicação } \\
n-165(24,6 \%)\end{array}$ & $\begin{array}{c}\text { Com } \\
\text { indicação } \\
\text { e tratado } \\
n-89(13,2)\end{array}$ & $\begin{array}{c}\text { Com } \\
\text { indicação } \\
\text { e não tratado } \\
n-418(62,2)\end{array}$ & & \\
\hline & $\mathbf{N}(\%)$ & $\mathbf{N}(\%)$ & & & \\
\hline $\begin{array}{l}\text { Sexo } \\
\text { Feminino } \\
\text { Masculino }\end{array}$ & $\begin{array}{c}107(64,8) \\
58(35,2)\end{array}$ & $\begin{array}{l}35(39,3) \\
54(60,7)\end{array}$ & $\begin{array}{l}227(54,3) \\
191(45,7)\end{array}$ & $\begin{array}{l}369(54,9) \\
303(45,1)\end{array}$ & 0,085 \\
\hline $\begin{array}{l}\text { Idade/diagnóstico } \\
0-14 \text { anos } \\
15-29 \text { anos } \\
30-39 \text { anos } \\
40-49 \text { anos } \\
\geq 50 \text { anos } \\
\text { Média de idade } \\
\text { Mediana } \\
\text { Min/Max }\end{array}$ & $\begin{array}{c}4(2,4) \\
68(41,2) \\
35(21,2) \\
35(21,2) \\
23(13,9) \\
34,0( \pm 13,2) \\
32 \\
8 / 66\end{array}$ & $\begin{array}{c}10(11,2) \\
35(39,3) \\
20(22,5) \\
17(19,1) \\
7(7,9) \\
30,3( \pm 12,4) \\
29 \\
5 / 56\end{array}$ & $\begin{array}{c}19(4,5) \\
161(38,5) \\
114(27,3) \\
86(20,6) \\
38(20,6) \\
32,7( \pm 12,3) \\
32,0 \\
0 / 72\end{array}$ & $\begin{array}{c}33(4,9) \\
264(39,3) \\
169(25,1) \\
138(20,5) \\
68(10,1) \\
32,7( \pm 12,6) \\
32,0 \\
0 / 72\end{array}$ & 0,386 \\
\hline $\begin{array}{l}\text { Idade primeira consulta } \\
0-14 \text { anos } \\
15-29 \text { anos } \\
30-39 \text { anos } \\
40-49 \text { anos } \\
\geq 50 \text { anos } \\
\text { Média de idade } \\
\text { Mediana } \\
\text { Min/Max }\end{array}$ & $\begin{array}{c}4(2,4) \\
63(38,2) \\
37(22,4) \\
37(22,4) \\
24(14,5) \\
34,7( \pm 13,1) \\
32,0 \\
8 / 66\end{array}$ & $\begin{array}{c}8(9,0) \\
33(37,1) \\
22(24,7) \\
17(19,1) \\
9(10,1) \\
30,9( \pm 12,7) \\
31,0 \\
6 / 56\end{array}$ & $\begin{array}{c}18(4,3) \\
155(37,1) \\
114(27,3) \\
87(20,8) \\
44(10,5) \\
33,3( \pm 12,5) \\
33,0 \\
1 / 73\end{array}$ & $\begin{array}{c}30(4,5) \\
251(37,4) \\
173(25,7) \\
141(21,0 \\
77(11,5) \\
33,3( \pm 12,7) \\
32,0 \\
1 / 73\end{array}$ & 0,326 \\
\hline $\begin{array}{l}\text { Tempo/acompanhamento } \\
1 \text { ano } \\
2 \text { anos } \\
3-4 \text { anos } \\
\geq 5 \text { anos } \\
\text { Média/acompanhamento } \\
\text { Mediana } \\
\text { Min/Max }\end{array}$ & $\begin{array}{c}117(70,9) \\
23(13,9) \\
7(4,2) \\
18(10,9) \\
1,9( \pm 1,9) \\
1,0 \\
1 / 10\end{array}$ & $\begin{array}{c}3(3,4) \\
2(2,2) \\
26(29,2) \\
58(65,2) \\
5,5( \pm 2,3) \\
5,0 \\
1 / 10\end{array}$ & $\begin{array}{c}112(26,8) \\
65(15,6) \\
119(28,5) \\
122(29,2) \\
3,5( \pm 2,4) \\
3,0 \\
1 / 10\end{array}$ & $\begin{array}{c}232(34,5) \\
90(13,4) \\
152(22,6) \\
198(29,5) \\
3,4( \pm 2,5) \\
3,0 \\
1 / 10\end{array}$ & $<0,0001$ \\
\hline
\end{tabular}

Quanto ao perfil sorológico e evolução clínica dos pacientes, segundo história de tratamento, as características estão apresentadas na Tabela 5. Em relação ao $\mathrm{HBeAg}$, o grupo de pacientes tratados foi o que apresentou maior proporção de $\mathrm{HBeAg}$ positivo em relação aos dois outros grupos $(36,0 \%$ versus $14,3 \%$ versus $3,1 \%, p=0,02)$.

Quanto à positividade para o anti $\mathrm{HBe}$ a maior proporção foi no grupo de pacientes sem indicação de tratamento e entre os pacientes do grupo 
com indicação mas que não recebeu tratamento quando comparado com o grupo de paciente que recebeu tratamento $(95,7 \%$ versus $85,5 \%$ versus $66,3 \% p=0,03)$.

A proporção de co-infecção com o vírus da hepatite $\mathrm{C}$ e com o vírus delta não apresentou diferença entre os grupos, porem o grupo dos pacientes que receberam tratamento apresentaram uma maior positividade para o VHC $(10,3 \%$ versus $2,0 \%$ versus $1,3 \% ; p=0,18)$ e para o VHD $(47,7 \%$ versus $23,0 \%$ versus $11,5 \% p=0,09$ ) respectivamente.

Quando comparamos o status sorológico do HBeAg e presença ou não do anti-delta, os pacientes que apresentavam positividade para o vírus delta e eram antiHBe positivo, teve maior proporção no grupo de paciente tratado $(36,4 \%$ versus $18,6 \%$ versus $10,3 \%)$ enquanto que pacientes com positividade apenas para o antiHBe com carga viral maior que $2000 \mathrm{Ul} / \mathrm{ml}$ e delta negativo, teve maior proporção no grupo de pacientes com indicação, mas que não receberam tratamento $(35,4 \%$ versus $13,6 \%$ versus $0,0 \%)$, $(p<0,0001)$.

A maior proporção de carga viral acima de $2000 \mathrm{UI} / \mathrm{ml}$ foi entre os pacientes do grupo com indicação, mas que não receberam tratamento e da carga viral menor que $2000 \mathrm{Ul} / \mathrm{ml}$ foi entre os pacientes do grupo sem indicação de tratamento ( $p<0,0001)$.

A biopsia hepática foi realizada em 30,1\% (202/672) dos pacientes, quando da intenção de tratar, ao compararmos o resultado da fibrose e inflamação não encontramos diferença entre os três grupos, embora o grupo de paciente tratado apresente maior proporção de pacientes com fibrose mais avançada (F2, F3, F4; 38,0\% versus $19,2 \%, p=0,145)$ e inflamação de moderada agrave ( $A 2, A 3 ; 32,0 \%$ versus $28,1 \%, p=0,655)$, respectivamente.

A pesquisa da carga viral do VHD começou a ser realizada na segunda metade de 2009, ainda de forma experimental e alguns dos pacientes já estavam em tratamento, não sendo possível fazer comparação entre os pacientes tratados ou não. Este exame foi realizado em 97 dos 149 pacientes com positividade para o antidelta. No grupo de pacientes com historia de tratamento com antidelta positivo e que realizaram o RNA-VHD 
(27/42), 37\% (10/27) desses pacientes mantinham níveis de VHD-RNA detectável. No grupo de pacientes sem tratamento com antiVHD positivo e que realizaram carga viral do VHD (70/107), 64,3\% (45/70) tinham a carga viral detectável, enquanto que $35,7 \%$ (25/70) a carga viral do VHD era menor que 75 cópias $/ \mathrm{ml}$.

A evolução para cirrose ocorreu em 8,5\% (57/672) desta população, não havendo diferença entre os grupos. Porém com tendência maior entre o grupo que recebeu tratamento $(29,2 \%$ versus $6,5 \%$ versus $2,4 \% p=0,80)$.

Os quatro pacientes do grupo sem indicação de tratamento que evoluíram para cirrose, todos eram antiHBe positivo, três tinham menos de 40 anos e associação com o vírus delta e o que não tinha associação com o vírus delta tinha mais de 40 anos.

Dos pacientes que tinham indicação de tratamento, que não trataram e que evoluíram para cirrose (27/418), vinte deles tinham infecção associada com o VHD.

Já nos pacientes tratados que evoluíram para cirrose (26/89), 16 deles tinham positividade para o VHD.

Comparando os três grupos quanto aos resultados dos exames bioquímicos iniciais (Tabela 6 ), verificou-se que o grupo que recebeu tratamento apresentou a média de ALT de 148,8UK, no grupo sem indicação de tratamento a média de ALT foi de $27,9 \mathrm{UK}$ e no grupo com indicação, mas que não foi tratado situou-se em 74,1 UK. O grupo que foi tratado teve maior proporção de pacientes com nível de ALT mais de cinco vezes o valor do limite superior de normalidade (>65UK) $(p<0,0001)$, maior proporção de pacientes com níveis de plaquetas abaixo de $150 \mathrm{mil} / \mathrm{mm}^{3} \quad(p=0,02)$, com níveis de gama GT duas vezes o valor superior de normalidade (>26U.L) $(p=0,001)$ e níveis de leucócitos abaixo de $3000 / \mathrm{mm}^{3} \quad(p=0,05)$, quando comparados com os que não receberam tratamento. Não houve diferença estatisticamente significante para o nivel de albumina $(p=0,570)$. 
Tabela 5. Característica do primeiro exame sorológico e histológico e da evolução clinica dos portadores crônicos do vírus da hepatite $\mathrm{B}$, segundo intenção de tratamento. Serviço de Assistência Especializada, 2000 a 2010. Rio Branco, Acre, Brasil.

\begin{tabular}{|c|c|c|c|c|c|}
\hline \multirow{3}{*}{ Características } & \multicolumn{3}{|c|}{ Tratamento } & \multirow[b]{3}{*}{$\begin{array}{c}\text { Total } \\
n-672(100)\end{array}$} & \multirow{3}{*}{$\underset{P}{\text { Valor } d e}$} \\
\hline & \multirow{2}{*}{$\begin{array}{c}\text { Sem } \\
\text { indicação } \\
n-165(24,6 \%) \\
\end{array}$} & \multicolumn{2}{|c|}{ Com indicacão } & & \\
\hline & & $\begin{array}{c}\text { Tratado } \\
n-89(13,2)\end{array}$ & $\begin{array}{c}\text { Não tratado } \\
n-418(62,2)\end{array}$ & & \\
\hline & $\mathbf{N}(\%)$ & $\mathbf{N}(\%)$ & $\mathbf{N}(\%)$ & $\mathbf{N}(\%)$ & \\
\hline $\begin{array}{l}\text { Presença HBeAg' } \\
\text { Não } \\
\text { Sim }\end{array}$ & $\begin{array}{c}157(96,9) \\
5(3,1)\end{array}$ & $\begin{array}{l}57(64,0) \\
32(36,0)\end{array}$ & $\begin{array}{c}348(85,7) \\
58(14,3)\end{array}$ & $\begin{array}{c}562(85,5) \\
95(14,5)\end{array}$ & 0,021 \\
\hline $\begin{array}{l}\text { Presença AntiHBe }{ }^{1} \\
\text { Não } \\
\text { Sim }\end{array}$ & $\begin{array}{c}7(4,3) \\
155(95,7)\end{array}$ & $\begin{array}{l}30(33,7) \\
59(66,3)\end{array}$ & $\begin{array}{c}59(14,5) \\
347(85,5)\end{array}$ & $\begin{array}{c}96(14,6) \\
561(85,4)\end{array}$ & 0,034 \\
\hline $\begin{array}{l}\text { Co infecção VHC } \\
\text { Não } \\
\text { Sim }\end{array}$ & $\begin{array}{c}148(98,0) \\
3(2,0)\end{array}$ & $\begin{array}{c}78(89,7) \\
9(10,3)\end{array}$ & $\begin{array}{c}388(98,7) \\
5(1,3)\end{array}$ & $\begin{array}{c}614(97,3) \\
17(2,7)\end{array}$ & 0,189 \\
\hline $\begin{array}{l}\text { Co-Infecção VHD } \\
\text { Não } \\
\text { Sim }\end{array}$ & $\begin{array}{c}131(88,5) \\
17(11,5)\end{array}$ & $\begin{array}{l}46(52,3) \\
42(47,7)\end{array}$ & $\begin{array}{c}301(77,0) \\
90(23,0)\end{array}$ & $\begin{array}{l}478(76,2) \\
149(23,8)\end{array}$ & 0,090 \\
\hline $\begin{array}{l}\text { Perfil sorológico } \\
\text { HBeAg (+) delta (-) } \\
\text { Anti } \mathrm{HBe}(+) \text { delta }(-)^{-} \\
\text {Anti } \mathrm{HBe}(+) \text { delta }(-)^{-*} \\
\mathrm{HBeAg}(+) \text { delta (+) } \\
\text { Anti } \mathrm{HBe}(+) \text { delta (+) }\end{array}$ & $\begin{array}{c}5(3,4) \\
125(85,6) \\
0(0,0) \\
1(0,7) \\
15(10,3)\end{array}$ & $\begin{array}{l}20(22,7) \\
14(15,9) \\
12(13,6) \\
10(11,4) \\
32(36,4)\end{array}$ & $\begin{array}{c}41(10,8) \\
120(31,6) \\
137(35,4) \\
17(4,4) \\
72(18,6)\end{array}$ & $\begin{array}{c}66(10,6) \\
259(41,7) \\
149(24,0) \\
28(4,5) \\
119(19,2)\end{array}$ & $<0,0001$ \\
\hline $\begin{array}{l}\text { CV do VHB (Ul/ml) } \\
\text { Indetectável } \\
<60 \\
60-2000 \\
>2000\end{array}$ & $\begin{array}{c}46(31,7) \\
15(10,3) \\
84(57,9) \\
0(0,0)\end{array}$ & $\begin{array}{c}19(22,1) \\
5(5,8) \\
24(27,9) \\
38(44,2)\end{array}$ & $\begin{array}{c}59(14,9) \\
31(7,8) \\
101(25,6) \\
204(51,6)\end{array}$ & $\begin{array}{c}124(19,8) \\
51(8,1) \\
209(33,4) \\
242(38,7)\end{array}$ & $<0,0001$ \\
\hline $\begin{array}{l}\text { Biopsia hepática } \\
\text { Fibrose } \\
\text { F0,F1 } \\
\text { F2,F3, F4 } \\
\text { Inflamação }\end{array}$ & $\begin{array}{l}6(100) \\
0(0,0)\end{array}$ & $\begin{array}{l}31(62,0) \\
19(38,0)\end{array}$ & $\begin{array}{c}118(60,8) \\
28(19,2)\end{array}$ & $\begin{array}{c}155(80,8) \\
28(19,2)\end{array}$ & 0,145 \\
\hline $\begin{array}{l}A 0, A 1 \\
A 2, A 3\end{array}$ & $\begin{array}{l}6(100) \\
0(0,0)\end{array}$ & $\begin{array}{l}34(68,0) \\
16(32,0)\end{array}$ & $\begin{array}{c}105(71,9) \\
41(28,1)\end{array}$ & $\begin{array}{c}145(71,8) \\
57(28,2)\end{array}$ & 0,655 \\
\hline $\begin{array}{l}\text { Evolução clínica } \\
\text { Hepatite } \\
\text { Cirrose }\end{array}$ & $\begin{array}{c}161(97,6) \\
4(2,4)\end{array}$ & $\begin{array}{l}63(70,8) \\
26(29,2)\end{array}$ & $\begin{array}{c}391(93,5) \\
27(6,5)\end{array}$ & $\begin{array}{c}615(91,5) \\
57(8,5)\end{array}$ & 0,802 \\
\hline
\end{tabular}

Exames não realizados para as variáveis (1) Antigeno "e" e anticorpo contra o antígeno "e" do virus B-15 pacientes, (2) anticorpo do virus da hepatite C - 41 pacientes, (3) anticorpo do vírus delta - 45 pacientes, (4) anticorpo antigeno "ë" e anticorpo do vírus delta - 51 pacientes; (5) CV-carga viral do vírus B - 46 pacientes, (6) Biopsia hepática 470 pacientes (Fibrose leve F0,F1, F2, Fibrose avançada F3 e F4) e (Inflamação leve A0, A1, Inflamação moderada a grave A2, A3); (*) VHB-DNA $\leq 2000 \mathrm{Ul} / \mathrm{ml} ;\left(^{* \star}\right) \mathrm{VHB}-\mathrm{DNA}>2000 \mathrm{Ul} / \mathrm{ml}$. 
Tabela 6. Características bioquímicas no início do seguimento, segundo intenção de tratamento, dos portadores crônicos do vírus da hepatite B. Serviço de Assistência Especializada, 2000 a 2010. Rio Branco, Acre, Brasil.

\begin{tabular}{|c|c|c|c|c|c|}
\hline \multicolumn{6}{|c|}{ Hepatite } \\
\hline \multirow[b]{3}{*}{ Características } & \multicolumn{3}{|c|}{ Tratamento } & \multirow[b]{3}{*}{$\begin{array}{c}\text { Total } \\
n-672(100)\end{array}$} & \multirow[b]{3}{*}{$\begin{array}{c}\text { Valor de } \\
\text { p }\end{array}$} \\
\hline & \multirow{2}{*}{$\begin{array}{c}\text { Sem } \\
\text { indicação }\end{array}$} & \multicolumn{2}{|c|}{ Com indicação } & & \\
\hline & & $\begin{array}{l}\text { Tratado } \\
n-89(13,2)\end{array}$ & $\begin{array}{l}\text { Não tratado } \\
n-418(62,2)\end{array}$ & & \\
\hline & $\mathbf{N}(\%)$ & $\mathbf{N}(\%)$ & & & \\
\hline $\begin{array}{l}\text { ALT (U/L)' } \\
\text { Média } \\
\text { Mediana } \\
\text { Min /Max } \\
\text { Normal } \\
>1 \text { a } 5 \times \text { LSN\# } \\
>5 \text { a } 10 \times \text { LSN } \\
>10 \times \text { LSN }\end{array}$ & $\begin{array}{c}27,9(13,0) \pm \\
27,0 \\
7 / 65 \\
156(100) \\
0(0,0) \\
0(0,0) \\
0(0,0)\end{array}$ & $\begin{array}{c}148,8( \pm 171,7) \\
100,5 \\
40 / 1240 \\
0(0,0) \\
46(52,3) \\
32(36,4) \\
10(11,4)\end{array}$ & $\begin{array}{c}74,1( \pm 90,8) \\
46,0 \\
11 / 1126 \\
74(18,0) \\
296(72,2) \\
29(7,1) \\
11(2,7)\end{array}$ & $\begin{array}{c}73,1( \pm 101,9) \\
43,5 \\
7 / 1240 \\
230(35,2) \\
342(52,3) \\
61(9,3) \\
21(3,2)\end{array}$ & $<0,0001$ \\
\hline $\begin{array}{l}\text { Plaquetas }\left(\mathbf{x} 10^{3}\right. \\
\text { Média } \\
\text { Mediana } \\
\text { Min /Max } \\
\geq 150 \\
<150\end{array}$ & $\begin{array}{c}217,8( \pm 56,2) \\
214,0 \\
100 / 451 \\
144(92,9) \\
11(7,1)\end{array}$ & $\begin{array}{c}186,1( \pm 72,0) \\
176,0 \\
32 / 520 \\
64(72,7) \\
24(27,3)\end{array}$ & $\begin{array}{c}211,9( \pm 68,9) \\
203,0 \\
22 / 533 \\
342(83,6) \\
69(16,8)\end{array}$ & $\begin{array}{c}209,8( \pm 67,2) \\
203,0 \\
22 / 533 \\
550(84,1) \\
104(15,9)\end{array}$ & 0,029 \\
\hline $\begin{array}{l}\text { Albumina (g/dl) } \\
\text { Média } \\
\text { Mediana } \\
\text { Min /Max } \\
\geq 3,5 \\
<3,5\end{array}$ & $\begin{array}{c}4,3( \pm 0,4) \\
4,4 \\
3,3 / 5,4 \\
141(94,6) \\
8(5,4)\end{array}$ & $\begin{array}{c}3,9( \pm 0,6) \\
4,0 \\
2,3 / 5,0 \\
69(81,2) \\
16(18,8)\end{array}$ & $\begin{array}{c}4,2( \pm 0,5) \\
4,2 \\
1,9 / 7,4 \\
358(91,3) \\
34(8,7)\end{array}$ & $\begin{array}{c}4,2( \pm 0,5) \\
4,2 \\
1,9 / 7,4 \\
568(90,7) \\
58(9,3)\end{array}$ & 0,570 \\
\hline $\begin{array}{l}\text { Gama GT(U/L) } \\
\text { Média } \\
\text { Mediana } \\
\text { Min /Max } \\
<2 \text { LSN } \\
\geq 2 \text { LSN }\end{array}$ & $\begin{array}{c}38,2( \pm 52,9) \\
26,0 \\
9,1 / 603 \\
147(97,4) \\
4(2,6)\end{array}$ & $\begin{array}{c}95,8( \pm 112,9) \\
56,0 \\
11 / 561 \\
39(45,3) \\
47(54,7)\end{array}$ & $\begin{array}{c}53,0(61,9) \\
34 \\
7 / 621 \\
314(78,3) \\
87(21,7)\end{array}$ & $\begin{array}{c}55,2(71,1) \\
33,0 \\
7 / 621 \\
500(78,4) \\
138(21,6)\end{array}$ & 0,001 \\
\hline $\begin{array}{l}\text { Leucocitos(mm } \\
\text { Média } \\
\text { Mediana } \\
\text { Min /Max }\end{array}$ & $\begin{array}{c}6191( \pm 2283) \\
6200,0 \\
1000 / 13200\end{array}$ & $\begin{array}{c}5605( \pm 2193) \\
5650 \\
1033 / 11390\end{array}$ & $\begin{array}{c}6317( \pm 2092) \\
6300 \\
1000 / 12520\end{array}$ & $\begin{array}{c}6191( \pm 2162) \\
6200 \\
1000 / 13200\end{array}$ & 0,059 \\
\hline$\geq 3000$ & $141(91,0)$ & $79(89,8)$ & $390(94,9)$ & $610(93,3)$ & \\
\hline$<3000$ & $14(9,0)$ & $9(10,2)$ & $21(5,1)$ & $44(6,7)$ & \\
\hline
\end{tabular}

Exames não realizados nas varáveis: (1)8 pacientes, (2)18 pacientes; (3)46 pacientes; (4)34 pacientes; (5)18 pacientes. 
5.2.3 Descrição das características dos indivíduos portadores crônicos do VHB sem cirrose à entrada do estudo, mono infectado ou com infecção dupla com o VHD

Do total de 672 pacientes, 93,3\% (627/672) submeteram-se ao exame sorológico para o VHD, deste 23,8\% (149/627) apresentaram o antidelta IgG positivo. As características sorológicas, histológicas e clínicas dos pacientes com mono infecção (VHB) e infecção dupla (VHB/NHD), está apresentada na Tabela 7. Os pacientes com infecção dupla apresentavam maior proporção do sexo masculino (55\% versus $41,2 \% ; p=0,002)$, maior proporção de carga viral do VHB indetectável (44,0\% versus $23,1 \%$; $p<0,0001)$.

Na biópsia hepática, os pacientes com dupla infecção apresentavam maior proporção de inflamação moderada a grave $(54,2 \%$ versus $16,3 \%$; $p<0,0001)$ e de fibrose avançada $(40,7 \%$ versus $14,8 \% ; p<0,0001)$. Os pacientes com VHB/VHD foram os que mais receberam terapia anti-VHB durante o acompanhamento $(28,2 \%$ versus $9,6 \%$; $p<0,0001)$ e também os que mais evoluíram para cirrose $(24,2 \%$ versus $4,2 \% ; p<0,0001)$.

Como a carga viral do VHD só foi possível a partir do segundo semestre de 2009, não foi feito análise comparativa, sendo realizada em $65,1 \%$ (97/149) dos pacientes antiVHD positivo. Dos 97 pacientes que realizaram o RNA do VHD, 56,7\% (55/97) apresentava carga viral acima do limite de detecção (75 cópias/ml). O VHB-DNA foi realizado em 94 dos 97 pacientes que realizaram o RNA-VHD.

Desses 94 pacientes que realizaram o VHB-DNA e o VHD-RNA, em $20,2 \%(19 / 94)$ o VHB e o VHD foram indetectável, $21,3 \%(20 / 94)$ tinha o VHB indetectável e o VHD acima de 75 cópias, 12,3\% (12/94) tinha o VHB acima de $2000 \mathrm{Ul} / \mathrm{ml}$ e VHD indetectável, 13,8\% (13/94) tinha VHD-RNA acima de 75 cópias/ml e VHB-DNA entre 61 e 2000Ul/ml e 20,2\% (19/94) tinham o VHD-RNA acima de 75 cópias/ml e o VHB-DNA acima de $2000 \mathrm{Ul} / \mathrm{ml}$. 
Tabela 7. Características dos portadores crônico do vírus da hepatite B com infecção associada ou não ao VHD, segundo aspectos sorológicos, histopatológico e clínico. Serviço de Assistência Especializada, 2000 a 2009. Rio Branco, Acre, Brasil.

\begin{tabular}{|c|c|c|c|c|c|}
\hline Características & $\begin{array}{c}\text { VHB } \\
n-478(91,5 \%) \\
N(\%) \\
\end{array}$ & $\begin{array}{c}\text { VHB/NHD } \\
n-149(8,5) \\
N(\%)\end{array}$ & OR bruto & IC95\% & $\begin{array}{c}\text { Valor de } \\
\mathbf{p}\end{array}$ \\
\hline $\begin{array}{l}\text { Sexo } \\
\text { Feminino } \\
\text { Masculino }\end{array}$ & $\begin{array}{l}281(58,8) \\
197(41,2)\end{array}$ & $\begin{array}{l}67(45,0) \\
82(55,0)\end{array}$ & 1,7 & $1,2-2,5$ & 0,002 \\
\hline $\begin{array}{l}\text { Presença } \mathrm{HBeAg}^{\prime} \\
\text { Não } \\
\text { Sim }\end{array}$ & $\begin{array}{c}408(86,1) \\
66(13,9)\end{array}$ & $\begin{array}{c}119(81,0) \\
28(19,0)\end{array}$ & 1,5 & $0,9-2,4$ & 0.085 \\
\hline $\begin{array}{l}\text { Presença AntiHBe }{ }^{1} \\
\text { Não } \\
\text { Sim }\end{array}$ & $\begin{array}{c}67(14,1) \\
407(85,9)\end{array}$ & $\begin{array}{c}28(19,0) \\
119(81,0)\end{array}$ & 0,7 & $0,4-1,1$ & 0,096 \\
\hline $\begin{array}{l}\text { Co infecção VHC } \\
\text { Não } \\
\text { Sim }\end{array}$ & $\begin{array}{c}450(97,2) \\
13(76,9)\end{array}$ & $\begin{array}{c}137(98,6) \\
2(1,4)\end{array}$ & 0,5 & $0,1-1,1$ & 0,288 \\
\hline Carga Viral VHB ${ }^{3}$ & & & & & $<0,0001$ \\
\hline $\begin{array}{l}\text { Indetectável } \\
\leq 2000 \\
>2000\end{array}$ & $\begin{array}{l}103(23,1) \\
149(33,4) \\
194(43,5)\end{array}$ & $\begin{array}{l}62(44,0) \\
42(29,8) \\
37(26,2)\end{array}$ & 0,5 & $0,3-0,7$ & \\
\hline $\begin{array}{l}\text { Biopsia hepática } \\
\text { Inflamação } \\
\text { A0, A1 } \\
\text { A2, A3 } \\
\text { Fibrose } \\
\text { F0,F1, F2 } \\
\text { F3, F4 }\end{array}$ & $\begin{array}{c}113(83,7) \\
22(16,3) \\
\\
115(85,2) \\
20(14,8)\end{array}$ & $\begin{array}{l}27(45,8) \\
32(54,2) \\
35(59,3) \\
24(40,7)\end{array}$ & 6,1 & $3,1-12,1$ & $<0,0001$ \\
\hline $\begin{array}{l}\text { Tramento } \\
\text { Não } \\
\text { Sim }\end{array}$ & $\begin{array}{c}432(90,4) \\
46(9,6)\end{array}$ & $\begin{array}{c}107(71,8) \\
42(28,2)\end{array}$ & 3,7 & $2,3-5,9$ & $<0,0001$ \\
\hline $\begin{array}{l}\text { Evolução } \\
\text { Hepatite } \\
\text { Cirrose }\end{array}$ & $\begin{array}{c}458(95,8) \\
20(4,2)\end{array}$ & $\begin{array}{c}113(75,8) \\
36(24,2)\end{array}$ & 7,3 & $4,1-13,1$ & $<0,0001$ \\
\hline
\end{tabular}

Alteração de ALT foi encontrada em $87 \%$ e $88,9 \%$ dos pacientes com VHD-RNA maior que 75 cópias $/ \mathrm{ml}$, no inicio e final do seguimento, respectivamente. $\mathrm{O} \mathrm{HBeAg}$ positivo foi maior entre os pacientes com VHDRNA detectável ( $25,9 \%$ versus $14,3 \%)$.

Entre os pacientes com infecção dupla (VHBNHD) a média de ALT foi mais alta do que entre os pacientes mono-infectados $(119,8$ UK versus 59,1UK; p<0,0001), no início do acompanhamento, com $84,6 \%$ dos 
pacientes com ALT alterada em comparação a $59,7 \%$ dos mono-infectados $(p<0,0001)$. Quando estratificado o valor do ALT em quantas vezes estava alterado em relação ao limite superior de normalidade (LSN), não houve diferença entre a proporção de paciente mono-infectados e os pacientes com infeç̧ão dupla que apresentaram no início do acompanhamento ALT de 1,5 até 5 vezes $\circ$ LSN $(52,0 \%$ versus $55,2 \%)$. A diferença foi encontrada com os valores acima de cinco vezes o LSN $(29,4 \%$ versus $7,6 \%, p<0,0001)$. Os pacientes mono-infectados tinham, no inicio do acompanhamento, maior percentual de ALT com valores dentro da normalidade ( $\leq 65 \mathrm{UK}),(40,3 \%$ versus $15,4 \%$ ).

O grupo de pacientes com dupla infecção também apresentavam maior proporção de plaquetas com nível abaixo de $150 \mathrm{mil} / \mathrm{mm}^{3}(34,5 \%$ versus $10,5 \% ; p<0,0001)$, nivel de albumina menor que $3,5 \mathrm{~g} / \mathrm{dl}(17,3 \%$ versus $7,0 \% ; p=0,001)$, nivel de gama GT maior que duas vezes o limite superior de normalidade $(44,5 \%$ versus $15,8 \% ; p<0,0001)$.

As alterações ultrassonográficas encontradas com maior proporção no grupo de pacientes com dupla infecção foram: hepatomegalia (15,7\% versus $5,0 \% ; p<0,0001)$, esplenomegalia $(21,4 \%$ versus $4,8 \% ; p<0,0001)$, fígado heterogêneo $(38,6 \%$ versus $16,6 \% ; p<0,0001)$, fígado com tamanho reduzido $(2,1 \%$ versus $0,2 \% ; p=0,045)$ (Tabela 8 ).

Durante $\circ$ acompanhamento, $\circ$ grupo de pacientes com dupla infecção (VHB/VHD) manteve alteração nos exames bioquímicos e ultrassonográfico. As características dessas alterações estão na Tabela 9. A média de ALT no final do seguimento foi maior no grupo de pacientes com dupla infeç̧ão $(87,9 \mathrm{U} / \mathrm{L}$ versus $37,3 \mathrm{U} / \mathrm{L})$, com $80,4 \%$ de $\mathrm{ALT}$ maior que 31U/L, o limite superior de normalidade, comparado com $46,3 \%$ nos pacientes mono-infectado $(p<0,0001)$.

Os pacientes com nivel de plaquetas menor que 150 mil, estavam em maior proporção no grupo com dupla infecção no final de seguimento $(37,9 \%$ versus $11,6 \%, p<0,0001)$, assim como as alterações na ultrassonografia, hepatomegalia $(16,3 \%$ versus $4,4 \%, p<0,0001)$, esplenomegalia $(38,8 \%$ versus $8,0 \%, p<0,0001)$, fígado heterogêneo $(63,3 \%$ versus $27,9 \%$, 
$p<0,0001)$, fígado diminuído $(11,2 \%$ versus $4,8 \%, p=0,03)$, dilatação de veia porta e ou esplênica $(22,4 \%$ versus $4,8 \%, p<0,0001)$ e o aparecimento de nódulo $(\mathrm{HCC})(8,2 \%$ versus $2,8 \%, \mathrm{p}=0,03)$.

Tabela 8. Características dos portadores crônico do vírus da hepatite B com infecção associada ou não ao VHD, segundo aspectos bioquímicos e ultrassonográfico iniciais. Serviço de Assistência Especializada, 2000 a 2009. Rio Branco, Acre, Brasil.

\begin{tabular}{|c|c|c|c|c|c|}
\hline Características & $\begin{array}{c}\text { VHB } \\
n-478(91,5 \%) \\
N(\%)\end{array}$ & $\begin{array}{c}\text { VHB/VHD } \\
\text { n-149(8,5) } \\
\mathrm{N}(\%)\end{array}$ & $\begin{array}{c}\text { OR } \\
\text { bruto }\end{array}$ & IC95\% & $\begin{array}{c}\text { Valor de } \\
\mathbf{p}\end{array}$ \\
\hline $\begin{array}{l}\text { ALT(U/L)' } \\
\text { Normal } \\
\text { Alterada }\end{array}$ & $\begin{array}{l}189(40,3) \\
280(59,7)\end{array}$ & $\begin{array}{c}22(15,4) \\
121(84,6)\end{array}$ & 3,7 & $2,3-6,1$ & $<0,0001$ \\
\hline $\begin{array}{l}\text { Plaquetas }\left(\times 10^{3} \mathrm{~mm}\right)^{2} \\
\quad \geq 150 \\
\quad<150\end{array}$ & $\begin{array}{c}418(98,5) \\
49(10,5)\end{array}$ & $\begin{array}{l}95(65,5) \\
50(34,5)\end{array}$ & 4,5 & $2,9-7,1$ & $<0,0001$ \\
\hline $\begin{array}{l}\text { Albumina }(\mathbf{g} / \mathrm{dl})^{3} \\
\quad \geq 3,5 \\
<3,5\end{array}$ & $\begin{array}{c}423(93,0) \\
32(7,0)\end{array}$ & $\begin{array}{c}110(82,7) \\
23(17,3)\end{array}$ & 2,8 & $1,6-4,9$ & 0,001 \\
\hline $\begin{array}{l}\text { Gama GT(U/L) } \\
<2 \text { LSN } \\
\geq 2 \text { LSN }\end{array}$ & $\begin{array}{c}390(84,4) \\
72(15,8)\end{array}$ & $\begin{array}{l}76(55,5) \\
61(44,5)\end{array}$ & 4,3 & $2,9-6,6$ & $<0,0001$ \\
\hline $\begin{array}{l}\text { Hepatomegalia }{ }^{5} \\
\text { Nao } \\
\text { Sim }\end{array}$ & $\begin{array}{c}419(95,0) \\
22(5,0)\end{array}$ & $\begin{array}{c}118(84,3) \\
22(15,7)\end{array}$ & 3,6 & $1,9-6,6$ & $<0,0001$ \\
\hline $\begin{array}{l}\text { Esplenomegalia } \\
\text { Nao } \\
\mathrm{Sim}\end{array}$ & $\begin{array}{c}420(95,2) \\
21(4,8)\end{array}$ & $\begin{array}{c}110(78,6) \\
30(21,4)\end{array}$ & 5,5 & $3,0-9,9$ & $<0,0001$ \\
\hline $\begin{array}{l}\text { Esteatose } \\
\text { Nao } \\
\text { Sim }\end{array}$ & $\begin{array}{c}407(92,3) \\
34(7,7)\end{array}$ & $\begin{array}{c}135(96,4) \\
5(3,6)\end{array}$ & 0,4 & $0,2-1,2$ & 0,059 \\
\hline $\begin{array}{l}\text { Figado heterogeneo } \\
\text { Nao } \\
\text { Sim }\end{array}$ & $\begin{array}{c}368(83,4) \\
73(16,6)\end{array}$ & $\begin{array}{l}86(61,4) \\
54(38,6)\end{array}$ & 3,2 & $2,1-4,8$ & $<0,0001$ \\
\hline $\begin{array}{l}\text { Figado diminuido } \\
\text { Nao } \\
\mathrm{Sim}\end{array}$ & $\begin{array}{c}440(99,8) \\
1(0,2)\end{array}$ & $\begin{array}{c}137(97,9) \\
3(2,1)\end{array}$ & 9,6 & $0,99-93,4$ & 0,045 \\
\hline $\begin{array}{l}\text { Dilatação Veia porta/esplenica } \\
\text { Nao } \\
\text { Sim }\end{array}$ & $\begin{array}{c}441(100) \\
0(0,0)\end{array}$ & $\begin{array}{c}139(99,3) \\
19(0,7)\end{array}$ & 0,2 & $0,2-0,3$ & 0,241 \\
\hline
\end{tabular}


Tabela 9. Características dos portadores crônico do vírus da hepatite B com infecção associada ou não ao VHD, segundo aspectos bioquímicos e ultrassonográfico no final do seguimento. Serviço de Assistência Especializada, 2000 a 2009. Rio Branco, Acre, Brasil.

\begin{tabular}{|c|c|c|c|c|c|}
\hline Características & $\begin{array}{c}\text { VHB } \\
n-478(91,5 \%) \\
N(\%) \\
\end{array}$ & $\begin{array}{c}\begin{array}{c}\text { VHB/VHD } \\
\mathrm{n}-149(8,5)\end{array} \\
\mathrm{N}(\%) \\
\end{array}$ & $\begin{array}{c}\text { OR } \\
\text { bruto }\end{array}$ & IC95\% & $\begin{array}{c}\text { Valor de } \\
\mathbf{p} \\
\end{array}$ \\
\hline $\operatorname{ALT}(\mathrm{U} / L)^{1}$ & & & & & $<0,0001$ \\
\hline $\begin{array}{l}\text { Normal } \\
\text { Alterada }\end{array}$ & $252(53,7)$ & $28(19,6)$ & & 3075 & \\
\hline Plaquetas $\left(\times 10^{3} \mathrm{~mm}\right)^{2}$ & $217(40,3)$ & & 4,7 & $3,0-1,0$ & $<0,0001$ \\
\hline$\geq 150$ & $413(88,4)$ & $90(62,1)$ & & & \\
\hline$<150$ & $54(11,6)$ & $55(37,9)$ & 4,7 & $3,0-7,3$ & \\
\hline Albumina(g/dl) ${ }^{3}$ & & & & & 0,001 \\
\hline $\begin{array}{l}\geq 3,5 \\
<3,5\end{array}$ & $\begin{array}{c}437(96,0) \\
18(4,0)\end{array}$ & $\begin{array}{c}117(88,0) \\
16(12,0)\end{array}$ & 3,3 & $1,6-6,7$ & \\
\hline Gama GT(U/L) ${ }^{4}$ & & & & & $<0,0001$ \\
\hline $\begin{array}{l}<2 \mathrm{LSN} \\
\geq 2 \mathrm{LSN}\end{array}$ & $\begin{array}{c}409(88,5) \\
53(11,5)\end{array}$ & $\begin{array}{l}87(63,5) \\
50(36,5)\end{array}$ & 4,4 & $2,8-7,0$ & \\
\hline Hepatomegalia $^{5}$ & & & & & $<0,0001$ \\
\hline $\begin{array}{l}\text { Nao } \\
\text { Sim }\end{array}$ & $\begin{array}{c}240(95,6) \\
11(4,4)\end{array}$ & $\begin{array}{l}82(83,7) \\
16(16,3)\end{array}$ & 4,3 & $1,9-9,5$ & \\
\hline Esplenomegalia & & & & & $<0,0001$ \\
\hline Nao & $231(92,0)$ & $60(61,2)$ & & & \\
\hline Sim & $20(8,0)$ & $38(38,8)$ & 7,3 & $4,0-13,5$ & \\
\hline Esteatose & & & & & 0,090 \\
\hline Nao & $222(88,4)$ & $92(93,9)$ & & & \\
\hline Sim & $29(11,6)$ & $6(6,1)$ & 0,5 & $0,2-1,2$ & \\
\hline Figado heterogeneo & & & & & $<0,0001$ \\
\hline Nao & $191(72,1)$ & $36(36,7)$ & & & \\
\hline Sim & $70(27,9)$ & $62(63,3)$ & 4,5 & $2,7-7,3$ & \\
\hline Figado diminuido & & & & & 0,030 \\
\hline Nao & $239(95,2)$ & $87(88,8)$ & & & \\
\hline Sim & $12(4,8)$ & $11(11,2)$ & 2,5 & $1,1-5,9$ & \\
\hline $\begin{array}{l}\text { Dilatação Veia } \\
\text { porta/esplenica }\end{array}$ & & & & & $<0,0001$ \\
\hline Nao & $239(95,2)$ & $76(77,6)$ & & & \\
\hline Sim & $12(4,8)$ & $22(22,4)$ & 5,8 & $2,7-12,2$ & \\
\hline Nódulo & & & & & 0,031 \\
\hline Não & $244(97,2)$ & $90(91,8)$ & & & \\
\hline Sim & $7(2,8)$ & $8(8,2)$ & 3,1 & $1,1-8,8$ & \\
\hline
\end{tabular}

5.2.4 Descrição das características dos indivíduos portadores crônicos do VHB, que evoluíram para cirrose durante o acompanhamento

5.2.4.1 Incidência de cirrose 
O estudo identificou entre os 672 pacientes com infecção crônica pelo vírus da hepatite $B$, sem cirrose no início do estudo, em um tempo de seguimento total de 2.127 pessoa-ano, a evolução para cirrose em 57 deles, ao final do período, com taxa de incidência para o período de $26,8 / 1000$ pessoa-ano (Tabela 10).

Tabela 10. Distribuição dos casos de infecção crônica pelo VHB, pessoaano e taxa de incidência de cirrose de 2000 a 2009, Rio Branco, Acre, Brasil.

\begin{tabular}{c|cc|cc|c}
\hline Ano & \multicolumn{2}{|c|}{ Hepatite } & \multicolumn{2}{c}{ Cirrose } & $\begin{array}{c}\text { Taxa de } \\
\text { incidência/1000 } \\
\text { pessoa-ano }\end{array}$ \\
\hline 2000 & $\mathrm{n}$ & Pessoa-ano & $\mathrm{n}$ & Pessoa-ano & 44,9 \\
2001 & 23 & 178,0 & 8 & 48,43 & 12,27 \\
2002 & 22 & 162,9 & 2 & 14,5 & 51,85 \\
2003 & 47 & 135,9 & 7 & 38,09 & 19,01 \\
2004 & 62 & 263,9 & 5 & 19,25 & 19,54 \\
2005 & 65 & 243,0 & 6 & 33,83 & 16,46 \\
2006 & 76 & 243,92 & 4 & 12,84 & 28,80 \\
2007 & 86 & 212,17 & 2 & 24,82 & 9,43 \\
2008 & 114 & 199,92 & 2 & 4,92 & 10,05 \\
2009 & 154 & 180,33 & 10 & 11,83 & 55,55 \\
\hline Total & 672 & 2127,29 & 57 & 212,93 & 26,8 \\
\hline
\end{tabular}

Analisando as taxas de incidência segundo história de tratamento, observou-se que dos 89 pacientes que receberam tratamento durante 0 acompanhamento, 26 evoluíram para cirrose, num total de 403 pessoa-ano de seguimento, ou seja, uma taxa de incidência para o período de 64,5/1000 pessoa-ano.

No mesmo período de acompanhamento, entre os 583 pacientes que não receberam tratamento, 31 evoluiram para cirrose, num total de 1875 pessoa-ano de seguimento, com uma taxa de incidência neste período de $16,5 / 1000$ pessoa-ano

\subsubsection{Análise bivariada}

O grupo de pacientes que evoluíram para cirrose $(57 / 672)$ durante 0 acompanhamento foi comparado com o grupo de pacientes que não 
evoluíram para cirrose (615/672). As características desta análise estão na Tabela 11. Analisando o total de pacientes, verificou-se que eram pacientes jovens, com 44,2\% (297/672) deles com menos de 30 anos de idade ao diagnóstico.

$\mathrm{Na}$ análise bivariada mostraram-se associadas à evolução para cirrose o sexo $(O R=2,2 ; \operatorname{IC} 95 \%$ 1,3-3,9), ter mais de cinco anos de acompanhamento $(\mathrm{OR}=3,7 ; \mathrm{IC} 95 \%$ 1,8-7,6), ter recebido medicamentos injetáveis com uso de seringa de vidro (OR=1,7; IC95\% 0,9-2.9). Quanto às outras variáveis sócio-epidemiológicas não se apresentaram associadas à progressão para cirrose (apêndice $3,4,5,6,7,8$ )

Tabela 11. Análise bivariada dos fatores associados à evolução para cirrose em portadores crônico do vírus da hepatite B acompanhados no Serviço de Assistência Especializada, 2000 a 2010. Rio Branco, Acre, Brasil.

\begin{tabular}{|c|c|c|c|c|c|}
\hline \multirow{3}{*}{ Características } & \multicolumn{2}{|c|}{ Evolução clínica } & & & \multirow[b]{2}{*}{$\begin{array}{c}\text { Valor de } \\
\mathrm{p}\end{array}$} \\
\hline & $\begin{array}{l}\text { Sem cirrose } \\
n-615(91,5 \%)\end{array}$ & $\begin{array}{c}\text { Com cirrose } \\
n-57(8,5)\end{array}$ & & & \\
\hline & $\mathbf{N}(\%)$ & $\mathbf{N}(\%)$ & OR bruto & IC95\% & \\
\hline $\begin{array}{l}\text { Sexo } \\
\text { Masculino } \\
\text { Feminino }\end{array}$ & $\begin{array}{l}267(43,4) \\
348(56,6)\end{array}$ & $\begin{array}{l}36(63,2) \\
21(36,8)\end{array}$ & $\begin{array}{l}1,0 \\
2,2\end{array}$ & $1,3-3,9$ & 0,003 \\
\hline $\begin{array}{l}\text { Idade/diagnóstico } \\
0-14 \text { anos } \\
15-29 \text { anos } \\
30-39 \text { anos } \\
40-49 \text { anos } \\
250 \text { anos }\end{array}$ & $\begin{array}{c}30(4,9) \\
248(40,3) \\
151(24,6) \\
124(20,2) \\
62(10,1)\end{array}$ & $\begin{array}{l}3(5,3) \\
16(28,1) \\
18(31,6) \\
14(24,6) \\
6(10,5)\end{array}$ & $\begin{array}{l}1.0 \\
0,6 \\
1,2 \\
1,1 \\
1,0\end{array}$ & $\begin{array}{l}0,2-2,3 \\
0,3-4,3 \\
0,6-4,2 \\
0,2-4,1\end{array}$ & 0,268 \\
\hline $\begin{array}{l}\text { Média de idadde } \\
\text { Min/Max }\end{array}$ & $\begin{array}{c}32,5( \pm 12,7) \\
0 / 72\end{array}$ & $\begin{array}{c}34,4( \pm 11,6) \\
6 / 60\end{array}$ & & & \\
\hline $\begin{array}{l}\text { Tempolacompanhamento } \\
1 \text { ano } \\
2 \text { anos } \\
3-4 \text { anos } \\
\geq 5 \text { anos }\end{array}$ & $\begin{array}{l}221(36,1) \\
88(14,3) \\
139(22,6) \\
167(27,2)\end{array}$ & $\begin{array}{c}11(19,3) \\
2(3,5) \\
13(22,8) \\
31(54,4)\end{array}$ & $\begin{array}{l}1,0 \\
0,4 \\
1,9 \\
3,7\end{array}$ & $\begin{array}{l}0,1-2,1 \\
0,8-4,3 \\
1,8-7,6\end{array}$ & $<0,0001$ \\
\hline Uso seringa de vidro* & & & & & 0,052 \\
\hline $\begin{array}{l}\text { Não } \\
\text { Sim }\end{array}$ & $\begin{array}{l}315(61,6) \\
196(38,4) \\
\end{array}$ & $\begin{array}{l}26(49,1) \\
27(50,9) \\
\end{array}$ & $\begin{array}{l}1,0 \\
1,7\end{array}$ & $0,9-2,9$ & \\
\hline
\end{tabular}

A análise bivariada das variáveis relativas aos exames sorológicos $\mathrm{e}$ histopatológicos está apresentada na Tabela 12. Mostraram-se associadas à 
evolução para cirrose, ter infecção associada com o VHC (OR=4,6; IC95\% 1,6-13,1), com o VHD (OR=7,3; IC95\% 4,1-13,1), apresentar antiHBe positivo e anti-delta positivo (OR=4,1; IC95\% 1,1-14,2), apresentar $\mathrm{HBeAg}$ positivo e anti-delta positivo (OR=3,9; IC95\% 1,4-10,7), ter na biopsia hepática atividade inflamatória moderada a grave (OR=3,3; IC95\% 1,4-7,6) e fibrose mais avançada (OR=8,2; IC95\% 3,4-19,7).

Tabela 12. Analise bivariada relativa aos primeiros exames sorológicos e histopatológicos associados à evolução para cirrose em portadores crônico do vírus da hepatite B. Serviço de Assistência Especializada, 2000 a 2010. Rio Branco, Acre, Brasil

\begin{tabular}{|c|c|c|c|c|c|}
\hline Características & $\begin{array}{c}\begin{array}{c}\text { Sem cirrose } \\
n-615(91,5 \%)\end{array} \\
N(\%) \\
\end{array}$ & $\begin{array}{c}\begin{array}{c}\text { Com cirrose } \\
n-57(8,5)\end{array} \\
N(\%) \\
\end{array}$ & OR bruto & IC95\% & $\begin{array}{c}\text { Valor de } \\
\text { p }\end{array}$ \\
\hline $\begin{array}{l}\text { Presença } \mathrm{HBeAg}^{1} \\
\text { Não } \\
\text { Sim }\end{array}$ & $\begin{array}{c}517(86,0) \\
84(14,0)\end{array}$ & $\begin{array}{l}45(80,4) \\
11(19,6)\end{array}$ & $\begin{array}{l}1,0 \\
1,5\end{array}$ & $0,7-3,0$ & 0,169 \\
\hline $\begin{array}{l}\text { Presença AntiHBe } \\
\text { Não } \\
\text { Sim }\end{array}$ & $\begin{array}{c}84(14,0) \\
517(86,0)\end{array}$ & $\begin{array}{l}12(21,4) \\
44(78,6)\end{array}$ & $\begin{array}{l}1,0 \\
0,6\end{array}$ & $0,3-1,1$ & 0,098 \\
\hline $\begin{array}{l}\text { Co infecção VHC } \\
\text { Não } \\
\text { Sim }\end{array}$ & $\begin{array}{c}563(97,9) \\
12(2,1)\end{array}$ & $\begin{array}{c}51(91,1) \\
5(8,9)\end{array}$ & $\begin{array}{l}1,0 \\
4,6\end{array}$ & $1,6-13,6$ & 0,012 \\
\hline $\begin{array}{l}\text { Co-Infecção VHD } \\
\text { Não } \\
\text { Sim }\end{array}$ & $\begin{array}{l}458(80,2) \\
113(19,8)\end{array}$ & $\begin{array}{l}20(35,7) \\
36(64,3)\end{array}$ & $\begin{array}{l}1,0 \\
7,3\end{array}$ & $4,1-13,1$ & $<0,0001$ \\
\hline $\begin{array}{l}\text { Perfil sorológico } \\
\text { HBeAg (+) delta }(-) \\
\text { Anti } \mathrm{HBe}(+) \text { delta }(-)^{-} \\
\text {Anti } \mathrm{HBe}(+) \text { delta }(-)^{-*} \\
\mathrm{HBeAg}(+) \text { delta (+) } \\
\text { Anti } \mathrm{HBe}(+) \text { delta (+) }\end{array}$ & $\begin{array}{c}61(10,8) \\
247(43,7) \\
146(25,8) \\
21(3,7) \\
90(15,9)\end{array}$ & $\begin{array}{c}5(8,9) \\
12(21,4) \\
3(5,4) \\
7(12,5) \\
29(51,8)\end{array}$ & $\begin{array}{l}1,0 \\
0,6 \\
0,2 \\
3,9 \\
4,1\end{array}$ & $\begin{array}{l}0,2-1,7 \\
0,1-1,1 \\
1,4-10,7 \\
1,1-14,2\end{array}$ & $<0,0001$ \\
\hline $\begin{array}{l}\text { CV do VHB (UI/mI) } \\
\text { Indetectável } \\
60-2000 \\
>2000\end{array}$ & $\begin{array}{l}158(27,5) \\
186(32,4) \\
230(40,1)\end{array}$ & $\begin{array}{l}17(32,7) \\
23(44,2) \\
12(23,1)\end{array}$ & $\begin{array}{l}1,0 \\
1,1 \\
0,5\end{array}$ & $\begin{array}{l}0,6-2,2 \\
1,1-4,2\end{array}$ & 0,059 \\
\hline $\begin{array}{l}\text { Biopsia hepática }^{6} \\
\text { Inflamação } \\
\text { A0, A1 } \\
\text { A2, A3 }\end{array}$ & $\begin{array}{c}132(75,4) \\
43(24,6)\end{array}$ & $\begin{array}{l}13(48,1) \\
14(51,9)\end{array}$ & $\begin{array}{c}1 \\
3,3\end{array}$ & $1,4-7,6$ & 0,005 \\
\hline $\begin{array}{l}\text { Fibrose } \\
\text { F0,F1, F2 } \\
\text { F3, F4 }\end{array}$ & $\begin{array}{c}145(82,9) \\
30(17,1)\end{array}$ & $\begin{array}{l}10(37,0) \\
17(63,0)\end{array}$ & $\begin{array}{c}1 \\
8,2\end{array}$ & $\begin{array}{c}1 \\
3,4-19,7\end{array}$ & $<0,0001$ \\
\hline
\end{tabular}

Exames não realizados para as variáveis (1)Antigeno "e" e anticorpo contra 0 antígeno "e" do virus B-15 pacientes, (2)anticorpo do virus da hepatite $C$ - 41 pacientes, (3)Anticorpo do virus delta - 45 pacientes, (4)anticorpo antigeno"ë" e anticorpo do vírus delta - 51 pacientes; (5)CV-carga viral do virus B - 46 pacientes, (6)Biopsia hepática 470 pacientes (Inflamação leve A0, A1, Inflamação moderada a grave A2, A3) e (Fibrose leve F0,F1, F2, Fibrose avançada F3 e F4); ( ${ }^{*}$ ) VHB-DNA $\leq 2000 \mathrm{Ul} / \mathrm{ml}$; (**)VHB-DNA >2000Ul/ml. 
A análise bivariada das variáveis laboratoriais bioquímicas no início e final do acompanhamento está apresentada na Tabela 13 e 14, mostrandose associada à progressão para cirrose, nível de ALT até cinco vezes o limite superior de normalidade ( $L S N=31)(O R=3,7 ; \quad I C 95 \% 1,5-9,1)$, ALT maior de cinco e menor que dez vezes o LSN (OR=11,1; IC95\% 4,1-30,4), ALT maior que dez vezes $\operatorname{LSN}(\mathrm{OR}=14,9 ; \mathrm{IC} 95 \%$ 4,3-51,9), nível de plaquetas menor que $150 \mathrm{mil} / \mathrm{mm}^{3}$ (OR=3,6; IC95\% 2,0-6,5), nível de albumina menor que 3,5g/dl (OR=2,7; IC95\% 1,3-5,6), nivel de gama GT maior que duas vezes o LSN (OR=6,5; IC95\% 3,7-11,7).

Durante o seguimento ainda mostrou-se fortemente associada à progressão para cirrose o nível de ALT até 2,5 vezes o LSN (OR=2,9; IC95\% 1,4-5,9), nível de ALT maior que 2,5 vezes o LSN (OR=7,5; IC95\% 3,4-16,5), nível de plaquetas menor que $150 \mathrm{mil} / \mathrm{mm}^{3}$ (OR=10,4; IC95\% 5,8-18,7), nível de albumina menor que 3,5g/dl (OR=3,2; IC95\% 1,4-7,5), nível de gama GT maior que duas vezes o LSN (OR=7,5; IC95\% 4,2-13,5) nivel de leucócito menor que 3000/mm $\mathrm{mm}^{3}$ (OR=4,0; IC95\% 1,8-8,9).

A análise bivariada das alterações ultrassonográficas encontradas tanto no inicio como durante o acompanhamento encontram-se na Tabela 15, mostrando associação à progressão para cirrose, a hepatomegalia (OR=2,7; IC95\% 1,2-6,0 e OR=3,0; IC95\% 1,3-7,1), esplenomegalia (OR=7,7; IC95\% 4,0-14,5), fígado heterogêneo (OR=7,6; IC95\% 4,2-13,5), fígado diminuído $(O R=31,1 ; \operatorname{IC} 95 \% 3,2-304,3)$ dilatação de veia porta (OR=423,5; IC95\% 55,5-3232) 
Tabela 13. Análise bivariada relativa aos marcadores bioquímicos iniciais associados à evolução para cirrose em portadores crônico do vírus da hepatite B. Serviço de Assistência Especializada, 2000 a 2010. Rio Branco, Acre, Brasil

\begin{tabular}{|c|c|c|c|c|c|}
\hline Características & $\begin{array}{c}\begin{array}{c}\text { Sem cirrose } \\
n-615(91,5 \%)\end{array} \\
N(\%)\end{array}$ & $\begin{array}{c}\begin{array}{c}\text { Com cirrose } \\
n-57(8,5)\end{array} \\
\mathrm{N}(\%)\end{array}$ & OR bruto & IC95\% & $\begin{array}{c}\text { Valor de } \\
\mathbf{p}\end{array}$ \\
\hline $\begin{array}{l}\text { ALT }(\text { UK) } \\
\text { Normal } \\
>1 \text { a } 5 \times \text { LSN\# } \\
>5 \text { a } 10 \times \text { LSN } \\
>10 \times \text { LSN }\end{array}$ & $\begin{array}{c}224(37,5) \\
311(52,1) \\
47(7,9) \\
15(2,5)\end{array}$ & $\begin{array}{c}6(10,5) \\
31(54,4) \\
14(24,6) \\
6(10,5)\end{array}$ & $\begin{array}{c}1,0 \\
3,7 \\
11,1 \\
14,9\end{array}$ & $\begin{array}{r}1,5-9,1 \\
4,1-30,4 \\
4,3-51,9\end{array}$ & $<0,0001$ \\
\hline $\begin{array}{l}\text { Média } \\
\text { Min /Max }\end{array}$ & $\begin{array}{c}69( \pm 104,0) \\
7 / 1240\end{array}$ & $\begin{array}{c}110(66,4) \\
25 / 303\end{array}$ & & & \\
\hline $\begin{array}{l}\text { Plaquetas }\left(\times 10^{3} \mathrm{~mm}\right)^{\star *} \\
\geq 150 \\
<150\end{array}$ & $\begin{array}{c}514(86,1) \\
83(14,0)\end{array}$ & $\begin{array}{l}36(63,2) \\
21(36,8)\end{array}$ & $\begin{array}{l}1,0 \\
3,6\end{array}$ & $2,0-6,5$ & $<0,0001$ \\
\hline $\begin{array}{l}\text { Média } \\
\text { Min /Max }\end{array}$ & $\begin{array}{c}212(64,9) \\
22 / 533\end{array}$ & $\begin{array}{c}182( \pm 82,8) \\
63 / 451\end{array}$ & & & \\
\hline $\begin{array}{l}\text { Albumina(g/dl) })^{\star \star *} \\
\geq 3,5 \\
<3,5\end{array}$ & $\begin{array}{c}523(91,8) \\
47(8,2)\end{array}$ & $\begin{array}{l}45(80,4) \\
11(19,6)\end{array}$ & $\begin{array}{l}1,0 \\
2,7\end{array}$ & $1,3-5,6$ & 0,009 \\
\hline $\begin{array}{l}\text { Média } \\
\text { Min /Max }\end{array}$ & $\begin{array}{c}4,2( \pm 0,51) \\
1,9 / 7,4\end{array}$ & $\begin{array}{c}3,9( \pm 0,58) \\
2,6 / 5,3\end{array}$ & & & \\
\hline $\begin{array}{l}\text { Gama GT(U.L) })^{\star \star \star *} \\
<2 \text { LSN } \\
\geq 2 \text { LSN }\end{array}$ & $\begin{array}{l}478(81,8) \\
106(18,1)\end{array}$ & $\begin{array}{l}22(40,7) \\
32(59,3)\end{array}$ & $\begin{array}{l}1,0 \\
6,5\end{array}$ & $3,7-11,7$ & $<0,0001$ \\
\hline $\begin{array}{l}\text { Média } \\
\text { Min /Max }\end{array}$ & $\begin{array}{c}49( \pm 62,2) \\
7 / 621\end{array}$ & $\begin{array}{c}118( \pm 117,2) \\
15 / 561\end{array}$ & & & \\
\hline $\begin{array}{l}\text { Leucocitos }\left(\mathrm{mm}^{3}\right)^{\star \star \star \star \star \star} \\
\geq 3000 \\
<3000\end{array}$ & $\begin{array}{c}559(93,6) \\
38(6,4)\end{array}$ & $\begin{array}{c}51(89,5) \\
6(10,5)\end{array}$ & $\begin{array}{l}1,0 \\
1,7\end{array}$ & $0,7-4,3$ & 0,175 \\
\hline Média & $6296( \pm 2143)$ & $5094( \pm 2066)$ & & & \\
\hline $\operatorname{Min} / \operatorname{Max}$ & $1000 / 13200$ & $1033 / 10900$ & & & \\
\hline
\end{tabular}

Exames não realizados nas varáveis: *18 pacientes, ${ }^{\star \star} 18$ pacientes; ${ }^{\star \star \star} 46$ pacientes; ${ }^{\star \star \star \star} 34$ pacientes; *****18 pacientes, \#LSN - Limite superior de normalidade 
Tabela 14. Análise bivariada relativa aos marcadores bioquímicos no final do acompanhamento, associados à evolução para cirrose em portadores crônico do vírus da hepatite B. Serviço de Assistência Especializada, 2000 a 2010. Rio Branco, Acre, Brasil

\begin{tabular}{|c|c|c|c|c|c|}
\hline Características & $\begin{array}{c}\begin{array}{c}\text { Sem cirrose } \\
n-615(91,5 \%)\end{array} \\
N(\%)\end{array}$ & $\begin{array}{c}\begin{array}{c}\text { Com cirrose } \\
n-57(8,5)\end{array} \\
N(\%)\end{array}$ & OR bruto & IC95\% & $\begin{array}{c}\text { Valor de } \\
\text { p }\end{array}$ \\
\hline $\begin{array}{l}\operatorname{ALT}(\mathrm{U} / \mathrm{L}))^{*} \\
\text { Normal } \\
>1 \text { a } 2,5 \times \mathrm{LVN \#} \\
>2,5 \times \mathrm{LVN}\end{array}$ & $\begin{array}{c}287(48,1) \\
244(40,9) \\
66(11,1)\end{array}$ & $\begin{array}{l}11(19,3) \\
27(47,4) \\
19(33,3)\end{array}$ & $\begin{array}{l}1,0 \\
2,9 \\
7,5\end{array}$ & $\begin{array}{c}1,4-5.9 \\
3,4-16,5\end{array}$ & $<0,0001$ \\
\hline $\begin{array}{l}\text { Média } \\
\text { Min/Max }\end{array}$ & $\begin{array}{c}46,7( \pm 64,3) \\
10 / 1140\end{array}$ & $\begin{array}{c}74( \pm 55,7) \\
16 / 268\end{array}$ & & & \\
\hline $\begin{array}{l}\text { Plaquetas }\left(\times 10^{3} \mathbf{~ m m}\right) \text { ** } \\
\geq 150 \\
<150\end{array}$ & $\begin{array}{c}518(86,8) \\
79(13,2)\end{array}$ & $\begin{array}{l}22(38,6) \\
35(61,4)\end{array}$ & $\begin{array}{c}1,0 \\
10,4\end{array}$ & $5,8-18,7$ & $<0,0001$ \\
\hline $\begin{array}{l}\text { Média } \\
\text { Min/max }\end{array}$ & $\begin{array}{c}214( \pm 59,8) \\
34 / 487\end{array}$ & $\begin{array}{c}149( \pm 61,3) \\
63 / 451\end{array}$ & & & \\
\hline Albumina(g/dl) ${ }^{\star * \star}$ & & & & & 0,010 \\
\hline$\geq 3,5$ & $542(95,1)$ & $48(85,7)$ & 1,0 & & \\
\hline$<3,5$ & $28(4,9)$ & $8(14,3)$ & 3,2 & $1,4-7,5$ & \\
\hline $\begin{array}{l}\text { Média } \\
\text { Min/max }\end{array}$ & $\begin{array}{c}4,2( \pm 0,42) \\
2 / 6,2\end{array}$ & $\begin{array}{c}3,9( \pm 0,61) \\
1,8 / 5,1\end{array}$ & & & \\
\hline $\begin{array}{l}\text { Gama GT(U/L) } \\
<2 \text { LSN } \\
\geq 2 \text { LSN }\end{array}$ & $\begin{array}{c}506(86,6) \\
78(13,4)\end{array}$ & $\begin{array}{l}25(46,3) \\
29(53,7)\end{array}$ & $\begin{array}{l}1,0 \\
7,5\end{array}$ & $4,2-13,5$ & $<0,0001$ \\
\hline $\begin{array}{l}\text { Média } \\
\text { Min/max }\end{array}$ & $\begin{array}{c}45,1( \pm 44,5) \\
9,1 / 435\end{array}$ & $\begin{array}{c}124( \pm 128) \\
10 / 786\end{array}$ & & & \\
\hline $\begin{array}{l}\text { Leucocitos }\left(\mathrm{mm}^{3}\right)^{\star \star * * * *} \\
\geq 3000 \\
<3000\end{array}$ & $\begin{array}{c}570(95,5) \\
27(4,7)\end{array}$ & $\begin{array}{c}48(84,2) \\
9(15,8)\end{array}$ & $\begin{array}{l}1,0 \\
4,0\end{array}$ & $1,8-8,9$ & 0,002 \\
\hline $\begin{array}{l}\text { Média } \\
\text { Min/max }\end{array}$ & $\begin{array}{c}6359( \pm 2026) \\
1000 / 14600\end{array}$ & $\begin{array}{c}4951( \pm 1980) \\
1360 / 9500\end{array}$ & & & \\
\hline
\end{tabular}

Exames não realizados nas varáveis: "18 pacientes, ${ }^{\star \star} 18$ pacientes; ${ }^{\star \star \star *} 46$ pacientes; ${ }^{\star \star \star \star} 34$ pacientes; *****18 pacientes 
Tabela 15. Análise bivariada relativa aos exames ultrassonográficos inicial e final do acompanhamento, associados à evolução para cirrose em portadores crônico do vírus da hepatite B. Serviço de Assistência Especializada*. 2000 a 2010. Rio Branco, Acre, Brasil

\begin{tabular}{|c|c|c|c|c|c|}
\hline \multirow[t]{2}{*}{ Caracteristicas } & $\begin{array}{l}\text { Sem cirrose } \\
n-615(91,5 \%)\end{array}$ & $\begin{array}{c}\text { Com cirrose } \\
n-57(8,5)\end{array}$ & \multirow{2}{*}{$\begin{array}{c}\text { OR } \\
\text { bruto }\end{array}$} & \multirow[t]{2}{*}{$95 \%$ IC } & \multirow{2}{*}{$\underset{p}{\text { Valor de }}$} \\
\hline & $\mathbf{N}(\%)$ & $\mathbf{N}(\%)$ & & & \\
\hline $\begin{array}{l}\text { Hepatomegalia' } \\
\text { Nao } \\
\text { Sim }\end{array}$ & $\begin{array}{c}525(93,6) \\
36(6,4)\end{array}$ & $\begin{array}{c}48(84,2) \\
9(15,8)\end{array}$ & $\begin{array}{c}1 \\
2,7\end{array}$ & $1,2-6,0$ & 0,016 \\
\hline $\begin{array}{l}\text { Hepatomegalia' } \\
\text { Nao } \\
\text { Sim }\end{array}$ & $\begin{array}{c}291(94,2) \\
18(5,8)\end{array}$ & $\begin{array}{c}48(84,2) \\
9(15,8)\end{array}$ & $\begin{array}{c}1 \\
3,0\end{array}$ & $1,3-7,1$ & 0,014 \\
\hline $\begin{array}{l}\text { Esplenomegalia' } \\
\text { Nao } \\
\text { Sim }\end{array}$ & $\begin{array}{l}24(93,4) \\
37(6,6)\end{array}$ & $\begin{array}{l}37(64,9) \\
20(35,1)\end{array}$ & $\begin{array}{c}1 \\
7,7\end{array}$ & $4,0-14,5$ & $<0,0001$ \\
\hline $\begin{array}{l}\text { Esplenomegalia }{ }^{2} \\
\text { Nao } \\
\text { Sim }\end{array}$ & $\begin{array}{c}288(93,2) \\
21(6,8)\end{array}$ & $\begin{array}{l}17(29,8) \\
40(70,2)\end{array}$ & $\begin{array}{c}1 \\
32,3\end{array}$ & $15,7-66,3$ & $<0,0001$ \\
\hline $\begin{array}{l}\text { Esteatose } \\
\text { Nao } \\
\text { Sim }\end{array}$ & $\begin{array}{c}521(92,9) \\
40(7,1)\end{array}$ & $\begin{array}{c}56(98,2) \\
1(1,8)\end{array}$ & $\begin{array}{c}1 \\
0,2\end{array}$ & $0,03-1,7$ & 0,090 \\
\hline $\begin{array}{l}\text { Esteatose } \\
\text { Nao } \\
\text { Sim }\end{array}$ & $\begin{array}{c}273(88,3) \\
36(11,7)\end{array}$ & $\begin{array}{c}56(98,2) \\
1(1,8)\end{array}$ & $\begin{array}{c}1 \\
0,1\end{array}$ & $0,02-1,0$ & 0,012 \\
\hline $\begin{array}{l}\text { Figado heterogeneo' } \\
\text { Nao } \\
\text { Sim }\end{array}$ & $\begin{array}{c}464(82,7) \\
97(17,3)\end{array}$ & $\begin{array}{l}22(38,6) \\
35(61,4)\end{array}$ & $\begin{array}{c}1 \\
7,6\end{array}$ & $4,2-13,5$ & $<0,0001$ \\
\hline $\begin{array}{l}\text { Figado heterogeneo } \\
\text { Nao } \\
\text { Sim }\end{array}$ & $\begin{array}{l}229(74,1) \\
80(25,9)\end{array}$ & $\begin{array}{c}0(0,0) \\
57(100,0)\end{array}$ & & & $<0,0001$ \\
\hline $\begin{array}{l}\text { Fígado diminuido' } \\
\text { Nao } \\
\text { Sim }\end{array}$ & $\begin{array}{c}560(99,8) \\
1(0,2)\end{array}$ & $\begin{array}{c}54(94,7) \\
3(5,3)\end{array}$ & $\begin{array}{c}1 \\
31,1\end{array}$ & $3,2-304,3$ & 0,003 \\
\hline $\begin{array}{l}\text { Figado diminuido }{ }^{2} \\
\text { Nao } \\
\text { Sim }\end{array}$ & $\begin{array}{c}308(99,7) \\
1(0,3)\end{array}$ & $\begin{array}{l}35(61,4) \\
22(38,6)\end{array}$ & $\begin{array}{c}1 \\
193,6\end{array}$ & $25,3-1480,4$ & $<0,0001$ \\
\hline $\begin{array}{l}\text { Dilatação Veia porta/esplenica' } \\
\text { Nao } \\
\text { Sim }\end{array}$ & $\begin{array}{c}561(100) \\
0(0,0)\end{array}$ & $\begin{array}{c}56(98,2) \\
1(1,9)\end{array}$ & & & 0,09 \\
\hline $\begin{array}{l}\text { Dilatação Veia porta/esplenica } \\
\text { Nao } \\
\text { Sim }\end{array}$ & $\begin{array}{c}308(99,7) \\
1(0,3)\end{array}$ & $\begin{array}{l}24(42,1) \\
33(57,9)\end{array}$ & $\begin{array}{c}1 \\
423,5\end{array}$ & $55,5-3232,1$ & $<0,0001$ \\
\hline
\end{tabular}

Total de exames não realizado nesta variável: (1 inicio do acompanhamento) 54 pacientes, (2 final do acompanhamento) 306 pacientes.

\subsubsection{Análise multivariada}

No primeiro modelo multivariado, foram incluídas aquelas variáveis que tinham apresentado na análise bivariada $p<0,05$, sexo, uso de seringa 
de vidro, co-infecção com o VHC, VHD, carga viral do VHB, atividade inflamatória e fibrose na biopsia hepática, plaquetas, albumina, ALT, Gama GT. O resultado do teste de razão de verossimilhança com $p \leq 0,05$ foi as que permaneceram no modelo.

Os resultados do modelo final são apresentados na Tabela 16. Mostrando-se associados à evolução para cirrose independente das demais exposições, após ajuste para tempo de acompanhamento: pertencer ao sexo masculino (OR=2,2; IC95\%: 1,1 - 3,7); co-infecção com VHC (OR= 4,6; IC95\%: 1,2-17,8); co-infecção pelo VHD na presença de HBeAg (OR = 4,0; IC95\%:1,3-11,9); co-infecção pelo VHD na presença de Anti $\mathrm{HBe}(\mathrm{OR}=7,1$; IC95\%:1,2-17,8 ), presença de gama GT >2 LSN (OR = 2,7; IC95\%:1,3-5,4).

Tabela 16. Modelo final da análise multivariada para investigação de fatores associados à evolução para cirrose entre pacientes com hepatite crônica pelo vírus $B$ para cirrose hepática.

\begin{tabular}{|c|c|c|c|c|}
\hline Fatores de risco & OR bruto & $\begin{array}{c}\text { OR } \\
\text { ajustado }\end{array}$ & $\begin{array}{c}\text { IC } \\
95 \% \\
\end{array}$ & $\begin{array}{c}\text { Valor } \\
\mathbf{P}\end{array}$ \\
\hline Sexo masculino & & & & 0,05 \\
\hline Feminino & 1,0 & 1,0 & & \\
\hline Masculino & 2,2 & 1,9 & $1,1-3,7$ & \\
\hline Tempo/acompanhamento & & & & 0,05 \\
\hline 1 ano & 1,0 & 1,0 & & \\
\hline 2 anos & 0,4 & 0,3 & $0,1-1,8$ & \\
\hline 3- 4anos & 1,9 & 1,3 & $0.5-3,4$ & \\
\hline 5 a mais anos & 3,7 & 2,0 & $0,8-4,9$ & \\
\hline Co infecção VHC & & & & 0,004 \\
\hline Sim & 1,0 & 1,0 & & \\
\hline Não & 4,6 & 4,6 & $1,2-17,8$ & \\
\hline $\begin{array}{l}\text { AntiVHD+antiHBe } \\
\mathrm{HBeAg}(+) \text { delta }(-)\end{array}$ & & & & $<0,0001$ \\
\hline Anti $\mathrm{HBe}(+)$ delta $(-)^{1}$ & $\begin{array}{l}1,0 \\
0,6\end{array}$ & $\begin{array}{l}1,0 \\
0,8\end{array}$ & $0,2-2,6$ & \\
\hline Anti $\mathrm{HBe}(+)$ delta $(-)^{2}$ & 0,2 & 0,4 & $0,1-1,8$ & \\
\hline HBeAg $(+)$ delta $(+)$ & 3,9 & 4,0 & $1,3-11,9$ & \\
\hline Anti $\mathrm{HBe}(+)$ delta $(+)$ & 4,1 & 7,1 & $1,2-17,8$ & \\
\hline Gama GT inicio & & & & $<0,0001$ \\
\hline$<2 \mathrm{LSN}$ & 1,0 & 1,0 & & \\
\hline$\geq 2$ LSN & 7,5 & 2,7 & $1,3-5,4$ & \\
\hline
\end{tabular}

(1) Carga viral do VHB $\leq 2000 \mathrm{Ul} / \mathrm{ml}$; (2) Carga viral do VHB > 2000Ul/ml. 
5.2.5 Descrição das características dos individuos portadores crônicos do VHB que evoluíram para cirrose segundo história de tratamento

Comparando os pacientes que evoluiram para cirrose segundo história de tratamento, com as características descritas na Tabela 17 , observa-se que mais de $50 \%$ eram do sexo masculino, houve uma proporção maior de $\mathrm{HBeAg}$ positivo nos pacientes tratados $(38,5 \%$ versus $3,3 \% ; p=0,001)$. Embora não houvesse diferença entre os dois grupos a coinfecção com o VHD tendeu ser maior no grupo de pacientes que evoluíram para cirrose, que não foram tratados $(66,7 \%$ versus $61,5 \%, p=0,45)$ e a carga viral do vírus B acima que $2000 \mathrm{UI} / \mathrm{ml}$ foi maior entre os pacientes com história de tratamento $(29,2 \%$ versus $17,9 \% ; p=0,373)$. A taxa de incidência de cirrose entre os pacientes tratados foi de $3,7 / 1000$ pessoas mês e entre os não tratados foi de $0,9 / 1000$ pessoa mês.

Mesmo não sendo possivel a comparação quanto à presença de viremia do delta, pois este exame começou a ser realizado em 2010 e só foi realizado em 40,4\% (23/57) dos pacientes que evoluíram para cirrose e alguns já haviam iniciado o tratamento (26/57), mas observa-se que a viremia se mantêm detectada em 45,5\% (5/11) dos pacientes que evoluíram para cirrose na vigência do tratamento e em $83,3 \%(10 / 12)$ dos que evoluíram para cirrose sem tratamento.

Nos 26 pacientes que fizeram biopsia hepática, a fibrose mais avançada foi mais freqüente nos pacientes em tratamento que evoluíram para cirrose $(71,4 \%$ versus $53,8 \% ; p=0,293)$, enquanto a inflamação moderada a grave foi maior entre os pacientes sem tratamento que evoluíram para cirrose (61,5\% vs $42,9 \%$; $p=0,280)$.

No grupo de pacientes com tratamento que evoluíram para cirrose tinham uma proporção maior de pacientes com mais de cinco anos de acompanhamento $(76,9 \%$ versus $35,5 \%$; $p=0,0001)$.

Comparando os resultados dos exames bioquímicos iniciais dos dois grupos, verificou-se que o grupo de pacientes que evoluiu para cirrose apresentou menor proporção de ALT dentro do padrão de normalidade 
( $0,0 \%$ versus $19,4 \%)$ e maior proporção de nível de ALT cinco ou mais vezes acima do limite superior de normalidade $(57,5 \%$ versus $16,1 \% ; p<0,0001)$, e gama GT duas vezes maior que o limite superior de normalidade $(84,0 \%$ versus $37,9 \% ; p=0,001$ ).

Os resultados dos exames de analise bioquímica finais que apresentaram diferença neste grupo, com maior proporção entre aqueles que evoluiram para cirrose e tinham história de tratamento foi o gama GT duas vezes maior que o limite superior de normalidade $(68,0 \%$ versus $41,4 \% ; p=0,04)$. Os outros exames não apresentaram diferença entre os dois grupos (Tabela 17) 
Tabela 17. Características sorológicas e histopatológicas dos pacientes que evoluíram para cirrose, segundo história de tratamento. Serviço de Assistência Especializada, 2000 a 2009. Rio Branco, Acre, Brasil.

\begin{tabular}{|c|c|c|c|}
\hline Características & $\begin{array}{c}\begin{array}{c}\text { Cirrose não } \\
\text { tratada } \\
\mathrm{n}-31(54,4 \%)\end{array} \\
\mathrm{N}(\%) \\
\end{array}$ & $\begin{array}{c}\begin{array}{c}\text { Cirrose } \\
\text { tratada } \\
n-26(45,6)\end{array} \\
N(\%) \\
\end{array}$ & $\begin{array}{c}\text { Valor de } \\
\mathbf{p}\end{array}$ \\
\hline $\begin{array}{l}\text { Sexo } \\
\text { Feminino } \\
\text { Masculino }\end{array}$ & $\begin{array}{l}13(41,9) \\
18(58,1)\end{array}$ & $\begin{array}{c}8(30,8) \\
18(69,2)\end{array}$ & 0,277 \\
\hline $\begin{array}{l}\text { Presença HBeAg' } \\
\text { Não } \\
\text { Sim }\end{array}$ & $\begin{array}{c}29(96,7) \\
1(3,3)\end{array}$ & $\begin{array}{l}16(61,5) \\
10(38,5)\end{array}$ & 0,001 \\
\hline $\begin{array}{l}\text { Presença AntiHBe' } \\
\text { Não } \\
\text { Sim }\end{array}$ & $\begin{array}{c}2(6,7) \\
28(93,3)\end{array}$ & $\begin{array}{l}10(38,5) \\
16(61,5)\end{array}$ & 0,005 \\
\hline $\begin{array}{l}\text { Co infecção VHC } \\
\text { Não } \\
\text { Sim }\end{array}$ & $\begin{array}{c}28(93,3) \\
2(6,7)\end{array}$ & $\begin{array}{c}23(88,5) \\
3(11,5)\end{array}$ & 0,431 \\
\hline $\begin{array}{l}\text { Co-Infecção VHD } \\
\text { Não } \\
\text { Sim }\end{array}$ & $\begin{array}{l}10(33,3) \\
20(66,7)\end{array}$ & $\begin{array}{l}10(38,5) \\
16(61,5)\end{array}$ & 0,452 \\
\hline $\begin{array}{l}\text { Perfil sorológico } \\
\text { HBeAg }(+) \text { delta }(-) \\
\text { Anti } \mathrm{HBe}(+) \text { delta }(-)^{-} \\
\text {Anti } \mathrm{HBe}(+) \text { delta }(-)^{-} \\
\mathrm{HBeAg}(+) \text { delta }(+) \\
\text { Anti } \mathrm{HBe}(+) \text { delta }(+)\end{array}$ & $\begin{array}{c}0(0,0) \\
8(26,7) \\
2(6,7) \\
2(6,7) \\
18(60,0)\end{array}$ & $\begin{array}{c}5(19,2) \\
4(15,4) \\
1(3,8) \\
5(19,2) \\
11(42,3)\end{array}$ & 0,544 \\
\hline CV do VHB (Ul/ml) $)^{5}$ & & & 0,391 \\
\hline Indetectável & $10(35,7)$ & $7(29,2)$ & \\
\hline $\begin{array}{l}60-2000 \\
>2001\end{array}$ & $\begin{array}{c}13(46.4) \\
5(17,9)\end{array}$ & $\begin{array}{c}10(41,7) \\
7(29,2)\end{array}$ & \\
\hline $\begin{array}{l}\text { Biopsia hepática } \\
\text { Inflamação } \\
\text { A0, A1 } \\
\text { A2, A3 }\end{array}$ & $\begin{array}{l}5(38,5) \\
8(61,5)\end{array}$ & $\begin{array}{l}8(57,1) \\
6(42,9)\end{array}$ & 0,280 \\
\hline $\begin{array}{l}\text { Fibrose } \\
\text { F0,F1, F2 } \\
\text { F3, F4 }\end{array}$ & $\begin{array}{l}6(46,2) \\
7(53,8)\end{array}$ & $\begin{array}{c}4(28,6) \\
10(71,4)\end{array}$ & 0,293 \\
\hline
\end{tabular}

Exames não realizados para as variáveis (1)Antigeno "e" e anticorpo contra 0 antigeno "e" do virus B-01 pacientes, (2) anticorpo do virus da hepatite C - 01 pacientes, (3) Anticorpo do virus delta - 01 pacientes, (4) anticorpo antigeno"ë" e anticorpo do virus delta - 01 pacientes; (5) CV-carga viral do virus B - 05 pacientes, (6) Biopsia hepática 30 pacientes (Fibrose leve F0,F1, F2, Fibrose avançada F3 e F4) e (Inflamação leve A0, A1, Inflamação moderada a grave A2, A3); (") VHB-DNA $\leq 2000 \mathrm{UI} / \mathrm{ml}$; (*) VHB-DNA $>2000 \mathrm{Ul} / \mathrm{ml}$. 
Tabela 18. Características bioquímicas no início e no final do seguimento dos pacientes que evoluíram para cirrose, segundo história de tratamento, no Serviço de Assistência Especializada, 2000 a 2010. Rio Branco, Acre, Brasil.

\begin{tabular}{|c|c|c|c|}
\hline Características & $\begin{array}{c}\begin{array}{c}\text { Cirrose não tratada } \\
\text { n-31( } 54,4 \%)\end{array} \\
\mathrm{N}(\%)\end{array}$ & $\begin{array}{c}\begin{array}{c}\text { Cirrose tratada } \\
n-26(45,6)\end{array} \\
N(\%)\end{array}$ & $\begin{array}{c}\text { Valor de } \\
\mathbf{p}\end{array}$ \\
\hline $\begin{array}{l}\text { ALT * } \\
\text { Normal } \\
>1 \text { a } 5 \times \text { LSN\# } \\
>5,0 \text { a } 10 \times \text { LSN } \\
210 \times \text { LSN } \\
\text { ALT final } \\
\text { Normal } \\
\text { Ate } 2,5 \times \text { LSN } \\
>2,5 \times \text { LSN }\end{array}$ & $\begin{array}{c}8(19,4) \\
20(64,5) \\
4(12,9) \\
1(3,2) \\
\\
8(25,8) \\
19(61,3) \\
7(22,6)\end{array}$ & $\begin{array}{c}0(0,0) \\
11(42,3) \\
10(38,5) \\
5(19,2) \\
\\
3(11,5) \\
17(65,4) \\
12(46,2)\end{array}$ & $<0,0001$ \\
\hline $\begin{array}{l}\text { Plaquetas }\left(\times 10^{3} \mathrm{~mm}\right) \\
\geq 150 \\
<150 \\
\text { Plaquetas }\left(\times 10^{3} \mathrm{~mm}\right) \text { final } \\
\geq 150 \\
<150\end{array}$ & $\begin{array}{l}17(54,8) \\
14(45,2) \\
13(41,9) \\
18(58,1)\end{array}$ & $\begin{array}{c}19(73,1) \\
7(26,9) \\
\\
9(34,6) \\
17(65,4)\end{array}$ & 0,126 \\
\hline $\begin{array}{l}\text { Albumina ** } \\
\geq 3,5\end{array}$ & $26(86,7)$ & $19(73,1)$ & 0,174 \\
\hline $\begin{array}{l}<3,5 \\
\text { Albumina final } \\
\geq 3,5 \\
<3,5\end{array}$ & $\begin{array}{c}4(13,3) \\
26(86,7) \\
4(13,3)\end{array}$ & $\begin{array}{c}7(26,9) \\
22(84,6) \\
4(15,4)\end{array}$ & 0,562 \\
\hline $\begin{array}{l}\text { Gama GT *** } \\
<2 \text { LSN } \\
\geq 2 \text { LSN } \\
\text { Gama GT final } \\
<2 \text { LSN } \\
\geq 2 \text { LSN }\end{array}$ & $\begin{array}{l}18(62,1) \\
11(37,9) \\
\\
17(58,6) \\
12(41,4)\end{array}$ & $\begin{array}{c}4(16,0) \\
21(84,0) \\
\\
8(32,0) \\
17(68,0)\end{array}$ & 0,001 \\
\hline $\begin{array}{l}\text { Leucocitos } \\
\geq 3000 \\
<3000 \\
\text { Leucocitos final } \\
\geq 3000 \\
<3000\end{array}$ & $\begin{array}{c}28(90,3) \\
3(9,7) \\
\\
27(87,1) \\
4(12,9)\end{array}$ & $\begin{array}{c}23(88,5) \\
3(11,5) \\
\\
21(80,8) \\
5(19,2)\end{array}$ & 0,385 \\
\hline
\end{tabular}

Exames não realizados nas varáveis: ${ }^{*} 1$ pacientes, ${ }^{\star \star} 1$ pacientes; ${ }^{\star \star \star} 4$ pacientes. 
5.2.6 Descrição das características dos indivíduos portadores crônicos do VHB sem cirrose à entrada do estudo, que evoluíram para carcinoma hepatocelular.

No final do seguimento $2,4 \%$ (16/672) pacientes evoluíram para carcinoma hepatocelular primário, $56,3 \%(9 / 16)$ do sexo masculino, $37,6 \%$ (6/16) com menos de 40 anos ao diagnóstico, 62,5\% (10/16) tinham cinco a mais anos de acompanhamento, 25\% (4/16) em paciente sem cirrose, $73,3 \% \%(11 / 15)$ eram antiHBe positivo, 53,3\% (8/15) tinha associação com o VHD, 35,7\% (5/14) tinham carga viral do VHB acima de 2000Ul/ml, 61,5\% (8/13) tinha alfetoproteina acima de $13 \mathrm{ng} / \mathrm{ml}$, com média de $2965 \mathrm{ng} / \mathrm{ml}$ mediana de $16 \mathrm{ng} / \mathrm{ml}$, variando de 0,8 a $34836,0 \mathrm{ng} / \mathrm{ml}, 31,3 \%(5 / 16)$ tinham história de tratamento antiviral e $75,0 \% \%(12 / 16)$ tinham evoluído para cirrose durante o acompanhamento. 


\section{DISCUSSÃO}

Estudos longitudinais proporcionam oportunidade de conhecer a história natural da infecção pelo VHB, desde o período da infecção, evolução para cronicidade, progressão para cirrose ou carcinoma hepatocelular e da sobrevida após a primeira descompensação da cirrose ou diagnóstico do HCC. Também proporciona ampliação dos conhecimentos, quanto às respostas ao tratamento, surgimento de resistência aos medicamentos pelo aparecimento de cepas mutantes, importância dos genótipos, do nível da carga viral e influência da associação com outros vírus, na progressão da doença (FATTOVICH et al., 2008; LIN et al., 2008; ROMEO et al., 2009; HADZIYANNIS, 2011).

Não encontramos na literatura, nenhum estudo realizado no Brasil, relativo à evolução clinica dos pacientes com infecção crônica pelo VHB ao longo do tempo. As pesquisas disponiveis têm por foco a estimativa de prevalência da infecção pelo VHB em vários serviços e sua distribuição regional em diferentes populações (Da SILVA et al.,1996; GALIZZI et al., 2010) ou de estudos transversais que mostram as características das formas clínicas da infecção crônica pelo VHB (CONDE et al., 2004; VICTÓRIA et al., 2008).

A região Amazônica se caracteriza por ser uma das regiões do mundo de maior prevalência da infecção pelo VHB. No Acre, os municípios de Porto Walter, Cruzeiro do Sul, Tarauacá, Feijó e Sena Madureira são consideradas regiões de maior endemicidade (VIANA et al., 2005). Porém desconhecemos a história natural da infecção crônica nesta região, já que não dispomos de estudos relativos ao tema.

Este estudo de coorte retrospectivo, de pacientes portadores crônicos do VHB, acompanhados no Serviço de Assistência Especializada, em Rio Branco, Acre, por um período de 10 anos, é o primeiro realizado no Brasil 
com o objetivo de estimar a incidência e de verificar os fatores associados à progressão para cirrose

As características sócio-demográficas encontrado na coorte estudada, de uma população jovem, residentes no interior do Estado, agricultores, com possivel modo de transmissão $\circ$ intra-familiar, com a presença de pelo menos um portador do VHB na família, assim como, o compartilhamento de material de uso pessoal, como sendo um dos possível fatores envolvidos na circulação e disseminação do VHB entre os familiares são semelhantes ao encontrado em outros estudos na região Norte (BRASIL et al., 2003; LOBATO et al., 2006; de PAULA et al., 2001; WORNEl et al., 2004).

A baixa escolaridade e baixo nível socioeconômico, observado também em outras regiões do Brasil (CLEMENS et al., 2000; PARANÁ \& ALMEIDA, 2005; VICTÓRIA et al., 2008; PEREIRA et al., 2009; CHACHÁ et al., 2010; GALIZZI et al., 2010), embora não seja clara sua relação com a evolução das formas clínicas na infecção crônica pelo VHB, alguns estudos sugerem que tais características podem influenciar a evolução da doença, indicando a relevância desses fatores na manutenção do padrão da infecção pelo VHB, assim como a necessidade de medidas de intervenção de saúde publica.

O Brasil tem como característica populacional a miscigenação racial, na Amazônia Ocidental alem dos nativos, existe uma mistura racial em decorrência da migração durante o apogeu econômico do ciclo da borracha e durante a fase mais intensa do programa federal desenvolvido com a finalidade de povoar a Amazônia com afluxo de nordestinos, sulistas do Paraná, Rio Grande do Sul. Tal característica fica explícita ao verificarmos, neste estudo, que $69,3 \%$ se autodenominavam parda, enquanto que, a população indigena abrangeu $3 \%$ da população do estudo.

Diferentemente ao que acontece na Ásia, a transmissão vertical é rara na Amazônia Ocidental, que se assemelha ao que acontece na bacia do mediterrâneo e África, onde a transmissão horizontal na infância precoce é o modo de transmissão predominante (HADZIYANNIS, 2011). Por sua vez, a duração da fase de infecção crônica HBeAg positivo é curta nessa região, se 
comparada com o que ocorre na Ásia (HADZIYANNIS, 2011). Durante a segunda década de vida a maioria dos pacientes HBsAg positivo são $\mathrm{HBeAg}$ negativo e anti-HBe positivo. As diferenças geográficas na história natural da infecção crônica do VHB são determinadas pela prevalência das características moleculares dos genótipos, subgenótipos e seus mutantes selecionados. O genótipo $D$ que é o mais freqüente na bacia do mediterrâneo (>90\%) e seu mutante pré-core que impede a produção do HBeAg está associada com a alta predominância de hepatite crônica HBeAg negativo nessa área, evoluindo para cirrose e HCC (HADZIYANNIS, 2011).

Observamos a predominância de pacientes com infecção crônica $\mathrm{HBeAg}$ negativo e antiHBe positivo, tendência que vem sendo observadas em estudos na Ásia, Europa (FATTOVICH et al., 2008; LIN et al., 2008) e no Brasil (TONETTO et al., 2009; CHACHÁ et al., 2010). Nos últimos 15 anos os estudos têm descrito aumento dos casos de hepatite crônica $\mathrm{HBeAg}$ negativo e AntiHBe positivo, com características clínicas e evolutivas própria, com flutuações de transaminases, do nivel de VHB-DNA e progressão para cirrose de forma insidiosa e alto risco de desenvolver carcinoma hepatocelular (FATTOVICH et al., 2003; FATTOVICH et al., 2002; LIN et al., 2008, CHACHÁ et al., 2010; GALIZZI et al., 2010). Este aspecto é relevante, uma vez que pode subsidiar condutas clínicas de acompanhamento, tratamento e intervenções de políticas públicas.

$O$ vírus da hepatite $B$ é um típico vírus não citopático. $A$ agressão hepática no decurso da infecção crônica pelo VHB, de variável severidade, é determinada pela estimulação da resposta imune protetora do indivíduo, causando dano e doença necroinflamatória persistente (FERRARI et al.,1990).

O curso natural da infecção pelo vírus $B$ pode ser modificado pela associação com outros vírus, como o VHD ou VHC com evolução mais grave da doença, com rápida progressão para cirrose hepática e carcinoma hepatocelular (BENSABATH et al., 1984; FONSECA, 2002; FONSECA et al., 2004; FATTOVICH et al., 2008). 
Neste estudo, mais da metade dos pacientes apresentava alguma alteração laboratorial ou ultrassonográfica, mostrando a severidade desta infecção e sinais da sua evolução para estágios mais avançados. Estes achados são semelhantes aos encontrados em estudos nacionais e internacionais (BENSABATH et al., 1984; QUINTERO et al., 2001; FONSECA, 2002; FONSECA et al., 2004; ROMEO et al., 2009; PARK et al., 2010), e revelam que, por mais que as condições ambientais, virais, étnicas sejam diferentes e tenham determinadas peculiaridades, todos sinalizam para a necessidade de se buscar políticas de saúde e condutas clínicas que minimizem o dano ao paciente, tanto físico, emocional, psíquica e econômica.

O desenvolvimento de cirrose e carcinoma hepatocelular em fase precoce da vida compromete o período economicamente produtivo dos pacientes, fazendo com que o impacto econômico associado à hepatite crônica pelo vírus B seja importante, já que, o custo do paciente com infecção crônica pelo VHB eleva-se, de acordo com o estágio evolutivo da infecção crônica, aumentando drasticamente nos estágios mais avançados da doença, pela elevada freqüência de intercorrências clínicas, tendo os procedimentos e medicamentos os componentes principais do gasto (CASTELO et al., 2007).

Os dados encontrados em nosso estudo, de que, os pacientes com infecção associada com o VHD apresentam, com maior freqüência, alterações laboratoriais, ultrassonográficas, com carga viral do VHB indetectável e evolução para as formas mais graves da infecção crônica, assim como, a presença de outros casos na família, mostrando a importância da transmissão intra-familiar, não diferem das encontradas em outros estudos internacionais e na Amazônia, (BENSABATH et al., 1984; FONSECA et al., 1994; WU et al., 1995; NIRO et al., 1999; SU et al., 1999; RIZZETO, 2000; BRAGA et al., 2001; QUINTERO et al., 2001, ERHARDT et al., 2003; PARANÁ et al., 2006, DEGERTEKIN et al., 2008; ROMEO et al., 2009; YURDAYDIN et al., 2010, WEDEMEYER \& MANNS, 2010). 
A associação do VHB e VHD na Amazônia é relevante, com ocorrência de surtos epidêmicos de doença ictero-hemorrágica e elevada prevalência de hepatopatia crônica e carcinoma hepatocelular, sendo descrita pela literatura nacional e internacional há mais de quatro décadas (BENSABATH et al., 1984; FONSECA et al., 1985; FONSECA et al., 1994; QUINTERO et al., 2001).

A alta prevalência da co-infecção pelo VHD, a presença de uma grande proporção de pacientes com alterações laboratoriais, ultrassonográfica e evolução para os quadros mais graves de hepatopatia crônica observado neste estudo e descrito por outros autores, na Amazônia Ocidental, levanta a necessidade de se realizar novas pesquisas, para melhor compreender a dinâmica desta infecção, confirmando ou não o que é observado em outros países, que mostram que esta evolução, estaria associada ao genótipo de ambos os vírus, presença de mutações e da carga viral (SAGNELLI et al., 2000; JARDI et al., 2001; QUINTERO et al., 2001; SU et al., 2006).

Esta necessidade é reforçada, pelo fato dos conhecimentos sobre a patogênese da infecção pelo VHD serem limitados e pelas diferenças clinicas observadas entre a evolução dos pacientes no Norte da América do Sul e dos pacientes dos países europeus, asiáticos e africanos, pois nestes, parece que a hepatite delta é uma doença imuno mediada, pois sua histologia não difere da histologia dos pacientes com hepatite $\mathrm{B}$ ou $\mathrm{C}$, e a quantidade e a qualidade da resposta das células $\mathrm{T}$ do hospedeiro estariam associadas com o grau de controle da infecção, e o nível de viremia do VHD não estaria diretamente associado com o estágio da doença hepática (WEDEMEYER \& MANNS, 2010). Mas, naqueles, parece que o VHD teria um efeito citopático, pois apresentam características histológicas incomuns e peculiares, como a presença de células em mórula e o vírus com multiplicação citoplasmática (BENSABATH et al., 1984; FONSECA et al., 1985; ANDRADE et al., 1992; FONSECA et al., 1994).

Podemos constatar também, neste estudo, que segundo o protocolo estadual, vigente a época, dos pacientes com indicação de tratamento, 
apenas uma minoria foi tratado e que mesmo não havendo diferença entre o grupo tratado e não tratado, o tratamento não impediu a evolução para cirrose, sendo que a taxa de incidência média (pessoa-ano) de cirrose, foi cerca de quatro vezes maior entre os pacientes tratados. Tais resultados devem ser interpretados com cautela, pois é um estudo retrospectivo, observacional e a adesão ao tratamento não foi avaliado. Porém, não é consistente com o objetivo final do tratamento da infecção crônica pelo VHB, que é de prevenir a cirrose, a falência hepática e HCC, através da supressão sustentada da replicação do VHB, observado pela diminuição da carga viral, perda do HBsAg e HBeAg com ou sem seroconversão, normalização da ALT e melhora na histologia hepática (GANEM et al., 2004; LOK \& McMAHON, 2007; LIAW, 2009).

Não temos dados suficientes para explicar os motivos de termos encontrado uma taxa de incidência de cirrose mais elevada entre o grupo tratado em relação ao grupo não tratado, possivelmente estar relacionada à maior proporção de casos graves e a maior prevalência de fatores prognóstico desfavoráveis entre os tratados (maior proporção de $\mathrm{HBeAg}$, de co-infecção com o VHC, de carga viral acima de $2000 \mathrm{Ul} / \mathrm{ml}$, de biopsia com F3 e F4, de alteração de ALT, de alteração de Gama GT)

Além disso, verificamos entre os tratados maior proporção de pacientes residindo no interior do estado, onde as condições de saúde são precárias e também que mais da metade dos pacientes que evoluiram para cirrose apresentam co-infecção com o VHD, condição amplamente aceita como associada à progressão da doença para as formas mais graves (BENSABATH et al., 1984; FONSECA et al., 1994; WU et al., 1995; ERHARDT et al., 2003 ; ROMEO et al., 2009; YURDAYDIN et al., 2010).

Tais resultados apontam a necessidade de novos estudos, para verificar que fatores estariam contribuindo para esta evolução, incluindo adesão, genótipo do VHB circulante, associação com o VHD e momento da introdução do tratamento, dentre outros.

Não existem trabalhos em nosso meio, que tenham estimado a taxa de incidência de cirrose em portadores de hepatite crônica $B$ e a 
comparação com os estudos em outros paises não é perfeita em virtude de diferenças étnicas, virais e de associação com outros vírus. Mas, apesar dessa ressalva, a taxa de incidência encontrada nesta população não difere daqueles encontrado em outros estudos (FATTOVICH et al., 2008; LIN \& $\mathrm{KAO}, 2008)$.

Os estudos de coorte na literatura internacional, tanto de população Oriental, como Ocidental, mostra o sexo, idade maior que 40 anos, carga viral, genótipo, severidade histológica na biopsia hepática, presença de mutantes do $\mathrm{VHB}$, nivel de $\mathrm{ALT}$, como fatores associados à progressão para cirrose (GANEM \& PRINCE, 2004; HADZIYANNIS et al., 2006; FATTOVICH et al., 2008; LIAW, 2009). Nesta coorte, os fatores que se mostraram como preditores de progressão para cirrose, após ajuste para o tempo de seguimento, foram: sexo, ter infecção associada com o VHC, com o VHD, semelhante aos dados encontrados na literatura (FATTOVICH et al., 1999; LIN \& KAO, 2008).

A idade avançada, acima de 40 anos e mais recentemente antiHBe positivo, são fatores preditivo independente de progressão para cirrose. Este fato é explicado, pela deterioração da função do sistema imunológico que ocorrem em pessoas mais velhas, conduzindo a uma replicação persistente do VHB e ao dano hepático contínuo e pelo maior tempo de infecção, com diminuição da prevalência do HBeAg e aumento da prevalência do anti-HBe com o aumento da idade, respectivamente (FATTOVICH et al., 1999; LAI \& YUEN, 2007; FATTOVICH et al., 2008; LOK et al., 2009). No Brasil, estudos de prevalência têm demonstrado que a cirrose é mais freqüente na idade acima de 40 anos (CHACHÁ et al., 2011; TONETTO et al., 2009; VICTORIA et al., 2008; GALIZZI et al., 2010).

Porém, neste estudo, embora a idade não tenha sido um fator importante de evolução para cirrose, chama atenção o fato de ser uma população jovem, com risco maior de progressão para cirrose de 30 a 39 anos, mais com cerca de dois terços dos pacientes no grupo da cirrose, no momento da primeira consulta e ao diagnóstico, com menos de 30 anos, 
diferindo desses autores, que mostram que a idade é positivamente relacionada com as alterações histológicas (ALAM et al., 2011).

Tais dados sinalizam que outros fatores podem estar influenciando a seroconversão do $\mathrm{HBeAg}$ e a evolução para cirrose em idade mais jovem. Talvez possa ser atribuída ao padrão de infecção na região amazônica, a proporção elevada de infecção associada ao VHD, ao genótipo F do VHB e genótipo III do VHD ou a outros fatores que necessitam ser elucidados (PARANÁ et al., 2006; QUINTERO et al., 2001).

Neste estudo, não se encontrou risco de progressão para cirrose, relacionado com o perfil do $\mathrm{HBeAg}$, demonstrado na maioria dos estudos longitudinais com portadores crônicos do VHB. Mas aqueles com antiHBe positivo, tinha um risco maior de desenvolver cirrose, tendência esta que vem sendo observado pelos pesquisadores, nos últimos 15 anos (FATTOVICH et al., 1999; LIN \& KAO, 2008; LIAW, 2009).

No presente estudo, não se encontrou risco de cirrose associada à carga viral, diferente do que é observado em vários estudos, onde o nível da carga viral é um preditor independente de evolução para cirrose (FATTOVICH et al., 1999; LIN \& KAO, 2008; LIAW, 2009). Este fato mostra que, outros fatores estariam influenciando a evolução para cirrose nesta população, como a infecções associada pelo VHD, que exerceria um efeito supressor sobre o VHB, ou mesmo prime dos PCR não adequado para os genótipos circulantes na região (RIZZETTO, 2000; SAGNELLI et al., 2000; LIN et al., 2008; ).

$\mathrm{Na}$ anáise multivariada os valores séricos da $\mathrm{ALT}$, albumina, plaquetas, não foram variáveis independentemente associadas à cirrose. A possível explicação para albumina e plaquetas é a de que, o nível sérico baixo da albumina e da contagem de plaquetas, à época da inclusão, estariam indicando doença hepática de longa duração, refletindo o estágio avançado da doença hepática, sendo importantes preditores da ocorrência de descompensação, mortalidade e de HCC, associada ao VHB do que progressão para cirrose (FATTOVICH et al., 2002; BEKKU et al., 2011). 
Considerando que a ALT é um marcador de presença ou ausência de atividade de doença hepática e, mesmo com as evidencias de que a extensão da necrose das células hepáticas e o grau de elevação do nível de ALT nem sempre estão correlacionados, estudos tem demonstrado que 0 risco de evoluir para cirrose e HCC é maior quanto maior for o nivel de ALT (HUO et al., 2000; FATTOVICH et al., 2002; BEKKU et al., 2011).

Neste estudo, o nível de $A L T$, que na análise bivariada se mostrou associada à progressão para cirrose, contudo após ajustada para gama GT, esta associação desapareceu, não tendo sido, portanto, um fator preditivo independente de cirrose, para os quais, as possíveis explicações devam ser investigadas, é um exame importante de monitoramento tanto para indicação de tratamento como de evolução, pois o risco de evoluir para cirrose foi maior naqueles com ALT alterada, alem do que em no nosso meio, o valor superior de normalidade do ALT, necessita ser revisto e padronizado, tanto para homem como para mulher, semelhante ao que sugerem estudos mais recentes (ALAM et al., 2011).

Nesta pesquisa foi encontrado, como variável importante e independentemente associada à progressão para cirrose, pertencer ao sexo masculino. Resultado semelhante ao encontrado por outros autores, que sugerem que ocorre uma maior progressão de fibrose hepática e HCC em homens e em mulheres depois da menopausa, possivelmente devido, pelo menos em parte, a uma produção mais baixa de estradiol e uma resposta reduzida para a sua ação (SHIMIZU et al., 2007). Porém, a compreensão melhor dos mecanismos básicos subjacentes as diferenças de sexo, associado à fibrogenese e a carcinógenese hepática necessitam ser estudadas, podendo abrir novos caminhos para a prevenção e tratamento da doença hepática crônica pelo VHB.

Neste estudo, também foi encontrado como fator independentemente associada à progressão para cirrose, a co-infecção com o VHC, semelhante ao observados por outros autores que referem que a infecção associada com o VHC causaria aumento no efeito citopático com piora do prognóstico, estando relacionado ao maior risco de hepatite fulminante, na fase aguda e 
de doença mais avançada como cirrose e HCC (FONG et al., 1991; LIAW, 1995).

O padrão mais freqüente de interação viral é $\circ \mathrm{VHC}$ suprimindo $\circ$ VHB. Embora o fenômeno de interferência seja descrito por vários autores, os mecanismos que regulam esta interação não estão completamente definidos.

NGUYEN et al., (2011), mostraram que a etnia e PONTISSO et al., (1996) mostraram que o genótipo do VHC é um importante fator na determinação da dominância viral, na dupla infecção VHC e VHB. Outra informação importante, reportada por outros autores é o efeito desta associação sobre a resposta ao tratamento, com pobre resposta a terapia (LIAW, 1995). A importância desses achados, em nosso estudo, é que sugere claramente a necessidade de monitoramento dos portadores crônicos do VHB, com políticas publicas e condutas clínicas, visando diminuir o impacto desta associação na progressão para cirrose.

Observou-se também, nessa coorte, que a co-infecção com o VHD, foi um fator independentemente associado à progressão para cirrose, independente do status do $\mathrm{HBeAg}$, com risco maior na presença do antiHBe positivo. Existe uma lacuna na literatura nacional sobre o mecanismo envolvido neste processo, dificultando a comparação entre os vários estudos.

A co-infecção pelo VHB/VHD está associada a um complexo e dinâmico padrão de dominância viral, sendo VHD freqüentemente associado com a supressão da replicação do VHB e seroconversão precoce do HBeAg. Existe uma forte associação com o vírus $\mathrm{B}$ mutante pré-core, a despeito da inibição do VHB, sugerindo, os autores, que os portadores do VHB, já teriam o mutante pré-core antes da super-infecção (WU et al., 1990; WU et al., 1995; JARDI et al., 2001; WEDERMAEYER \& MANNS, 2010; YURDAYDIN et al., 2010).

A hepatite delta é considerada uma das formas mais severas de hepatite viral humana, com evolução clínica associada à rápida progressão para fibrose com descompensação hepática precoce e maior risco para 
desenvolvimento de carcinoma hepatocelular, possivelmente relacionada com o genótipo. Esta rápida evolução ocorria principalmente em pacientes mais velhos e, parece resultar da replicação persistente do VHD, com nível mais alto de células T CD4 + citotóxicas no fígado do que no sangue e que elas se acumulariam com a idade (WU et al., 1990; WU et al., 1995; JARDI et al., 2001; WEDERMAEYER \& MANNS, 2010; YURDAYDIN et al., 2010).

Nossos achados diferem da literatura internacional, mas são consistentes com os dados da Amazônia Ocidental, onde as características dos pacientes com infecção pelo VHD são de pacientes jovens, com grande proporção apresentando replicação ativa tanto do vírus $B$ quanto do vírus delta, com quadro grave, evoluindo precocemente para cirrose. Esta diferença ocorreria, possivelmente, pelo padrão de infecção, pelo padrão de resposta vírus-hospedeiro e pelos genótipos circulantes na região (genótipo III do VHD e genótipo F do VHB) (BENSABATH et al., 1984; WORNEl et al., 2004; FONSECA et al., 1994; PARANÁ et al., 2006). Esses achados levantam questões com implicações em condutas clínicas, com referência a uma situação polêmica, que é a associação ou não de medicamentos, o momento mais indicado para o início do tratamento e, alem da necessidade de estudos para caracterizar a dinâmica viral em nossa região.

Em nosso estudo não se pôde determinar o tempo exato da superinfecção ou mesmo o tempo de duração da infecção do VHB com o VHC ou VHD nos pacientes.

Outro dado encontrado em nosso estudo é a gama-glutamiltranspeptidase (GGT), como fator independente de progressão para cirrose. Esta enzima, encontrada no fígado, pâncreas, rins, próstata e no plasma, embora tenha maior concentração no tecido renal, têm sua importância clínica ligada às doenças do fígado e vias biliares (colestase e lesões hepáticas inflamatórias e tóxicas). No parênquima hepático, está presente, no interior dos hepatócitos e nas células epiteliais biliares, sendo considerada marcadora de lesão hepatocelular de alta sensibilidade (PRATT et al., 2000; DUFOUR et al., 2000) mas, de pouca especificidade, uma vez que pode está alterada por uso de medicações, álcool e varias doenças 
sistêmicas, como as morbidades da síndrome metabólica (RANTALA et al., 2000; SUKUGAWA et al., 2004).

Embora na literatura inexistam relatos sobre a gama GT, como fator preditor de cirrose na hepatite $B$, estudos recentes tem usado a gama GT, como biomarcador de fibrose em teste não invasivos de diagnóstico de cirrose em hepatite B (PARK et al., 2010; LEE et al., 2011). Esse achado, no nosso estudo, precisa ser mais bem estudado, até para se definir se a gama GT é importante como fator de progressão para cirrose ou de prognóstico no paciente portador crônico do VHB.

Com esses resultados, podemos sintetizar que, progridem para cirrose os pacientes jovens, do sexo masculino, com co-infecção com o VHD ou VHC, e que apresentaram alteração de gama GT.

Além disso, ainda que não se tenha estimado o tempo entre o momento da infecção e a evolução para cirrose, nem o momento da infecção pelo VHD ou pelo VHC ou mesmo a adesão do paciente ao tratamento, verificamos que este teve uma associação negativa, com impacto sobre o tempo de evolução para cirrose, mas não sobre sua incidência.

Sempre levando em conta os aspectos risco/beneficio, esses resultados mostram-se relevantes à medida que podem subsidiar políticas de saúde pública e condutas clínicas em intervenções focalizando os grupos identificados como de maior risco.

Dentre as limitações do presente estudo, vale citar que a coorte formada por pacientes portadores crônicos do VHB é soroprevalentes, pois desconhecemos o momento da infecção, impossibilitando estivar o tempo de infecção, parâmetro importante para determinar o tempo livre de cirrose. Além disso, pode haver viés de seleção e alguma polarização de referência, já que nossa instituição é um centro de referência terciária para hepatite $B$ crônica.

Outra limitação é o fato de termos utilizado uma única estimativa para os marcadores virológicos, como o nível de VHB-DNA, que podem apresentar variações durante o curso natural da infecção, especialmente durante a fase imuno-ativa nos indivíduos com hepatite crônica $\mathrm{HBeAg}$ 
negativos. Outra limitação a ser citada é a ausência de marcadores virológicos para a confirmação de hepatite delta ativa.

Como é um estudo de uma população inserida em um serviço de vida real, a falta de dados em alguns prontuários, a qualidade dos exames de imagem, foi outro fator limitante. A introdução nos últimos anos de acompanhamento, de exames de imagem de alta qualidade, provocou um aumento de casos de cirrose diagnosticado mais precocemente, elevando a incidência no ultimo ano.

O tratamento pouco eficaz e o uso prolongado de medicamentos podem levar ao surgimento de resistência, de efeitos adversos das drogas e da redução na adesão, necessitando de estratégias que possam minimizar esses riscos potenciais ((BARTHOLOMEUSZ et al., 2006).

Apesar das limitações, nossos resultados mostraram-se consistente com a literatura, além de que sinaliza pontos, que devem ser investigados, como por exemplo, fatores que influenciam a cirrose em idade precoce, a resposta ao tratamento e papel da gama GT na historia natural da infecção crônica pelo VHB.

Os estudos longitudinais, mesmo com suas limitações, podem ser utilizados na avaliação de intervenções, com a finalidade de subsidiar políticas públicas e condutas clínicas, com o objetivo de se detectar precocemente as alterações e intervir com condutas clinicas que prolonguem o tempo ou evitem a evolução para cirrose.

O governo brasileiro, desde 2002, com a criação do PNHV, tem procurado dar resposta de forma integrada e harmônica quanto à promoção da saúde, prevenção e assistência para o combate e controle das hepatites. Ao longo desses nove anos, vem renovando suas ações, pautando-as segundo as diretrizes que regem o SUS, com atenção integral e universal às pessoas afetadas por este agravo.

São numerosas as ações de saúde pública com este objetivo, como por exemplo, nos programas de atenção primária, com o aumento da faixa etária de cobertura vacinal, com medidas que visam aumentar a testagem e identificar mais precocemente os indivíduos infectados através da 
disponibilidade de testes rápidos, além, da atualização dos protocolos de tratamento da hepatite $\mathrm{B}$ e $\mathrm{C}$, incorporando os avanços mais recentes.

O governo do Acre, também está preocupado em levar para a população acriana uma atenção integral e universal à saúde, com incorporação imediata das diretrizes nacional, ampliação dos serviços de atendimento aos hepatopatas crônicos, além de buscar estratégias para aumentar a cobertura vacinal contra o VHB na faixa etária de menos de 20 anos.

Esperamos que este estudo possa contribuir nas discussões a respeito da história natural da infecção pelo VHB na Amazônia brasileira, na tomada de decisões quanto a condutas clínicas, na criação de estratégias de saúde publica para prevenir a super infecção pelo VHD, de forma a prolongar ao máximo o tempo de evolução para cirrose, com boa qualidade de vida, assim como, sinalize para realização de novos estudos sobre resistência aos medicamentos e analise de custo e beneficio. 


\section{CONCLUSÕES}

\subsection{Conclusão geral}

Nosso estudo mostrou que, sexo masculino, infecção associada com ○ VHD ou VHC e alteração de gama GT têm risco aumentado de progressão para cirrose hepática.

\subsection{Conclusões especificas}

> A infecção crônica pelo VHB na coorte estudada está associada a pacientes jovens, com mais de $60 \%$ dos pacientes apresentando idade inferior a 30 anos

> A transmissão intrafamiliar foi o modo provável de transmissão mais freqüente, relatado por mais de $70 \%$ dos pacientes

> Baixo nivel de escolaridade, residir no interior do estado, profissão de agricultor e atividades do lar foi relatado em mais de $60 \%$ dos pacientes

$>$ Os possiveis fatores de exposição, relatados por mais de $50 \%$ dos pacientes foram, compartilhamento de objetos cortantes, compartilhamento de escova de dente, uso de medicações injetáveis com seringa de vidro, tratamento dentário, transfusão de sangue e cirurgia

> A transmissão sexual e o uso de drogas ilicitas foram relatados como prováveis formas de transmissão, respectivamente em $6 \%$ e $4 \%$ dos casos estudados.

> A história de vacinação contra a hepatite B, com três doses, foi relatada por cerca de $50 \%$ dos pacientes 
> Portador crônico do VHB com antiHBe positivo foi o marcador mais freqüente, assinalado em mais de $80 \%$ dos pacientes da coorte estudada

> Hepatite crônica foi detectada em torno de $65 \%$ dos pacientes da coorte estudada

$>$ Co-infecção com o VHC foi observada em $2,7 \%$ dos casos

$>$ A infecção associada com o VHD foi de $23,8 \%$

$>$ A prevalência de cirrose foi de $8,5 \%$

A taxa de incidência de cirrose para o período do estudo foi de 26,8/1000 pessoa-ano.

$>$ Os fatores independentes associados à progressão para cirrose, após ajuste para o tempo de seguimento, foram:

- Pertencer ao sexo masculino (OR=1,9; IC95\% 1,0-3,7)

- Co-infeç̧ão com o VHC (OR=4,6; IC95\% 1,2 - 17,8)

- Infecção associada ao VHD na presença de HBeAg (OR = 4,0; IC95\%:1,3-11,9)

- Infecção associada ao VHD na presença de Anti HBe $(O R=$ 7,$1 ;$ IC95\%:1,2-17,8)

- Nivel de Gama GT maior do que duas vezes o LSN (OR = 2,7; IC95\%:1,3-5,4) 


\section{REFERENCIAS BIBLIOGRAFICAS}

1. Alam S, Ahmad N, Mustafa G, Shrestha A, Akm KA, Khan M. Evaluacion of normal or minimally elevated alanine transaminase, age and DNA level in predicting liver histological changes in chronic hepatitis B. Liver Inter. 2011;31:824-830.

2. Ali SA, Donahue RM, Qureshi $H$, Vermund $S H$. Hepatitis $B$ end hepatitis $C$ in Pakistan: prevalence and risk factores. Inter J Infect Dis. 2009;13(1):9-19.

3. Alter MJ. Epidemiology and Prevention of hepatitis B. Sem Liver Dis. 2003;23(1):39-46.

4. Alter MJ. Epidemiology of hepatitis B in Europe and Wordwide. J Hepatol. 2003,39:S64-S69.

5. Andrade ZA, Lesbordes JL, Ravisse P, Paraná R, Prata A, Barberino JS, Trepo C. Fulminant hepatitis with microvesicular steatosis (a histologic comparision of cases occurring in Brazil - Labrea hepatitis - and in central Africa - Bangui hepatitis). Rev Soc Bras Med Trop. 1992;25:155-160

6. Arauz-Ruiz P, Norder H, Robertson BH, Magnius LO. Genotype H: a new Amerindian genotype of hepatitis B virus revealed in Central America. J Genic Virol. 2002;83:2059-2073.

7. Bartholomeusz A, Locarnini SA. Antiviral drug resistance: clinical consequences and molecular aspects. Semin Liver Dis. 2006;26:162-170.

8. Bedossa $P$, Bioulac-Sage $P$, Collard $P$ et al. Quelle classification pour les hépatites chroniques? Las lençons du virus de l'hépatite C. Gastroenterol Clin Biol. 1994;18:403

9. Bedossa et al. Intraobserver and interobserver variations in liver biopsy interpretation in patients with chronic hepatitis C. The French METAVIR cooperative study. Hepatol. 1994;20(1):1-20.

10. Bekku D, Arai M, Imazeki F, Yonemitsu Y, Kanda T, Fujiwara K, Fukai K, Sato $\mathrm{K}$, Itoga S, Nomura F, Yokosuka O.Long-term follow-up of patients with hepatitis B e antigen negative chronic hepatitis B. J. Gastroenterol \& Hepatol. 2011, 26:122-128.

11. Bensabath G, Dias LB. Hepatites Lábrea e outras hepatites fulminantes em Sena Madureira, Acre e Boca do Acre, Amazonas, Brasil. Instituto de Med Trop de São Paulo, 1983; 25: 182-194.

12. Bensabath G, Hadler SC, Soares MCP, Fields H, Dias LB, Popper H, Maynard JE. Hepatitis Delta Virus infection and Lábrea hepatitis. Prevalence and role in fulminant hepatitis in the Amazon basin. JAMA. 1987;258:479-483.

13. Benvegnu' L, Gios M, Boccato S, Alberti A. Natural history of compensated viral cirrhosis: a prospective study on the incidence and hierarchy of major complications. Gut 2004; 53:744-749.

14. Bertoletti A, D'Elios MM, Boni C, De Carli M, Zignego AL, Durazzo M, Missale G, Penna A, Fiaccadori F, Del Prete G, Ferrari C. Different cytokine profiles of 
intrahepatic $T$ cells in chronic hepatitis B and hepatitis $C$ virus infections. Gastroenterology. 1997;112:193-199.

15. Becker CE, Mattos AA, Bogo MR, Branco F, Sitinik R, Kretzmann NA. Genotyping of hepatitis B virus in a cohort of patients evaluated ina hospital of Porto Alegre, South of Brasil. Arq gastroenterol. 2010;47(1):12-17.

16. Bondini S, Kallman J, Wheeler A, Prakash S, Gramlich T, Jondle DM, et al. Impacto f non-alcolic fatty liver disease on chronic hepatitis B. Liver Int. 2007; 27:607-611.

17. Boom, R., et al., Rapid and simple method for purification of nucleic acids. J Clin Microbiol. 1990; 28;(3): 495-503

18. Braga WSM, Brasil LM, Souza RAB, Melo MS, Rosas MDG, Castilho MC, Fonseca JCF. Prevalencia da infecção pelos virus da hepatite $B$ (VHB) e da hepatite delta (VHD) em Lábrea, Rio Purus, Estado do Amazonas. Epid e Serv Saúde. 2004;13(1):35-46.

19. Braga WSM; Castilho MC; Santos ICV; Moura MAS; Segurado AC. Low prevalence of hepatitis $B$ virus, hepatitis $D$ virus and hepatitis $C$ virus among patients with human immunodeficiency virus or acquired immunodeficiency syndrome in the Brazilian Amazon basin. Rev. Soc. Bras. Med. Trop. 2006; 39(6):519-522.

20. Braga WSM, Brasil LM, Souza RAB, Castilho MC, Fonseca JC. Ocorrência da infecção pelo vírus da hepatite $B(\mathrm{VHB})$ e delta (VHD) em sete grupos indigenas do Estado do Amazonas. Rev Soc Bras Med Trop.2001; 34(4):349-355.

21. Brasil LM, Fonseca JCF, Souza RB, Braga WSM, Toledo LM. Prevalência de marcadores para o vírus da hepatite $B$ em contatos domiciliares no Estado do Amazonas. Rev Soc Bras Medi Trop. 2003;36(5): 565-570.

22. Brunetto MR, Oliveti F, Cocco B, Leandro G, Colombatto P, Gorin JM, et al. Otucome of anti-Hbe positive chronic hepatits $B$ in alpha-interferon treated and untreated patients: a long term cohort study. J Hepatol. 2002;36:263-270.

23. Campos RH, Mbayed VA, Pineiro e Leone FG. Molecular epidemiology of hepatitis B virus in Latin America. J Clin Virol. 2005,34(2):S8-13.

24. Carrilho FJ, Moraes CR, Pinho JRR, Mello IMVGC, Bertolini DA, Lemos MF, Moreira RC, Bassit LC, Cardoso RA, Santos GR, Da Silva LC. Hepatitis B virus infection in Haemodialysis Centres from Santa Catarina State, Southern Brazil. Predictive risk factors for infection and molecular epidemiology. BMC Public Health. 2004;4:1-11.

25. Castelo A, Pessoa MG, Barreto TCBB, Alves MRD, Araujo DV. Estimativas de custo da hepatite crônica B no Sistema Único de Saúde Brasileiro em 2005. Assoc Med Bras. 2007;53(6):486-91

26. Center for Disease Control. Recommendations for protection against viral hepatitis. Recommendations of the Immunization Practices Advisory Committee (ACIP). MMWR 1985;34:313-335.

27. Center for Disease Control. Prevention of perinatal transmission of hepatitis $B$ virus: Prenatal screening of all pregnant women of hepatitis $B$ surface antigen. 
Recommendations of the Immunization Practices Advisory Committee (ACIP). MMWR. 1988;37:341-346.

28. Chachá SGF, Ferreira SC, Costa TV, Almeida Filho LC, Villanova MG, Souza FF, Teixeira AC, Castro JF, Figueiredo SZ, Ramalho LN, Passos ADC, Martinelli ALC. Clinical, demographic and epidemiological characteristics of patients with hepatitis $B$ followed at a university hospital in southeastern Brazil: predominance of HBeAg negative cases. Rev Soc Bras Med Trop 2011;44(1):13-17.

29. Chen CJ, Yang HI, Su J, Jen CL, You SL, Lu SN, et al. Risk of hepatocellular carcinoma across a biological gradient of serum hapatits $B$ virus DNA level. JAMA. 2006;295:65-73.

30. Chen Y-P, Dai L, Wang J-L, Zhu Y-F, Feng X-R, Hou J-L. Model consisting of ultrasonographic and simple blood indexes accurately identify compensated hepatitis B cirrhosis. J Gastroenterol Hepatol. 2008;23:1228-1234.

31. Chiari, F.V., C. Ferrari, Hepatitis B virus immunopathogenesis. Ann Rev Immunol.1995;13:29-60.

32. Chu C-J, Lok AS. Clinical utility in quantifying serum HBV-DNA levels using PCR assays. J Hepatol.2002;36:549-551.

33. Chu CM, Liaw YF. Genotype C hepatitis B virus infection is associated with a higher risk of reactivation of hepatits $B$ and progression to cirrhosis than genotype $B$ : a longitudinal study of hepatitis $B$ e antigen-positive with normal aminotransferase levels at baseline. J Hepatol. 2005;43:411-417.

34. Conde SR, Moia L d eJ, Barbosa MS, Amaral I do S, Miranda EC, Soares M Do C, Brito EM, Souza O do S, de Araújo MT, Demachki S, Rebello JR, Mesquita MG, Denis $A B$, Ishak $R$. Prevalence of hepatitis $B$ virus genotypes and the occurrence of precore mutation A-1896 and to correlate them with the clinical presentation of chronic hepatitis, in a population group of the Eastern Amazon region. Rev Soc Bras Med Trop. 2004; sup 2:33-9.

35. D'Amico G, Garcia-Tsao G, Pagliaro L. Natural history and prognostic indicators of survival in cirrhosis: A systematic review of 118 studies. J Hepatol 2006;44: 21731.

36. Davila JA, Morgan RO, Shaib Y, McGlynn KA, El-Serag HB. Diabetes increases the risk of hepatocellular carcinoma in the United States: a population based case control study. Gut. 2005;54:533-539.

37. Davis JP. Experience with hepatits A and B vaccine. Am J Med. 2005;118(10):715.

38. de Paula VS, Arruda ME, Vitral CL, Gaspar AMC. Seroprevalence of Viral Hepatitis in River Communities from the Western Region of the Brazilian Amazon Basin. Mem Inst Oswaldo Cruz, Rio de Janeiro, 2001;Vol. 96(8):1123-1128

39. Degertekin H, Yalçin K, Yakut M, Yurdaydin C. Seropositivity for delta hepatitis in patients with chronic hepatitis $B$ and liver cirrhosis in Turkey: a meta-analysis. Liver Int. 2008;28:494-498.

40. Desmet VJ, Gerber M, Hoofnagle JH, Manns M, Scheuer PJ. Classification of chronic hepatitis: diagnosis, grading and staging. Hepatology. 1994;19:1513-1520. 
41. Donato F, Gelatti U, Limina RM, Fattovich G. Southern Europe as na example of interaction between various environmental factors: A systematic review of the epidemiologic evidence. Oncogene. 2006;25:3756-3770.

42. Donati G. Validazione Dell'accuratezza diagnostica di uma rete neurale artificiale nella predizione della fibrosi epatica da epatite HCV stadiata com biopsia epatica ecoguidata [tese de doutorado]. Itália. Facolta 'di Medicina e Chirurgia da Universitá degli Studi di Bologna, 2005.

43. Dufour DS, Lott JÁ, Nolte FS, Gretch DR, Koff RS, Seef LB. Diagnosis and monitoring of hepatic injury.Performance characteristics of laboratory tests. Clin Chem. 2000;46(12):2027-2049.

44. EASL International Consensus Conference on Hepatitis B. 13-14 September, 2002: Geneva, Switzerland. Consensus statement (short version). J Hepatol. 2003;38:533-540.

45. El-Serag HB, Hampel H, Javadi F. The association between diabetes and hepatocellular carcinoma: a systematic review of epidemiologic evidence. Clin Gastroenterol Hepatol. 2006;4:369-380.

46. Erhardt A, Knuth R, Sagir A, Kirschberg O, Heintges T, Häussinger D. Socioepidemiological data on hepatitis delta in a German university clinic-increase in patients from Eastern Europe and the former Soviet Union. Z. Gastroenterol. 2003.41:523-526.

47. Farci $P$, Mandas A, Coiana A et al. Treatment of chronic hepatitis D with alfa2a. N Engl J Med 1994; 330:88-94.

48. Fattovich G, Giustina G, Christensen E et al. Influence of hepatitis delta virus infection on morbidity and mortality in compensated cirrhosis type B. Gut.2000; 46:420-426

49. Fattovich G, Pantalena M, Zagni I, Realdi G, Schalm SW, Christensen E. Effect of hepatitis $B$ and $C$ virus infections on the natural history of compensated cirrhosis: a cohort study of 297 patients. Am J Gastroenterol. 2002;97:2886-2895.

50. Fattovich G, Brollo L, Giustina G, Noventa F, Pontisso P, Alberti A, Realdi G, Ruol A. Natural history and prognostic factors for chronic hepatitis type B. Gut. 1999, 32:294-298.

51. Fattovich G, Bortolotti F, Donato F. Natural history of chronic hepatitis B: Special emphasis on disease progression and prognostic factors. J Hepatology. 2008; 48: 335-352

52. Fattovich G. Natural history an prognosis of hepatitis B. Semin Liver Dis. 2003;23:47-68.

53. Fattovich G. Natural history of hepatitis B. J Hepatol. 2003;39: S50-S58'

54. Ferrari C, Penna A, Bertoletti A, Valli A, Degli Antoni A, Giuberti T, Cavalli A, Petit M-A, Fiaccadori F. Cellular immune response to hepatitis $B$ virus-encoded antigens in acute and chronic hepatitis B virus infection. J.Immunol. 1990; 145: 3442-3449.

55. Ferreira RC, Teles SA, Dias MA, Tavares VR, Silva SA, Gomes SA, Yoshida CF, Martins RM. Hepatitis B virus infection profile in hemodialysis patients in Central 
Brazil: prevalence, risk factors, and genotypes. Mem Inst Oswaldo Cruz. 2006;101:689-92.

56. Fong T-L, Di Bisceglie AM, Waggoner JG, Bankes SM, Hoofnagle JH. The significance of antibody to hepatitis $\mathrm{C}$ virus in patients with chronic hepatitis $\mathrm{B}$. Hepatol.1991;14 (1): 63-67.

57. Fonseca JCF, Gayotto LCC, Ferreira LCL, Araújo JR, Alecrim WD, Santos RTM, Simonetti JP, Alves VAF. Labrea hepatitis-Hepatitis B and delta antigen expression in liver tissue: Report $f$ three autopsy cases (Preliminary report). Rev Inst Med Trop São Paulo. 1985,27(4):224-227.

58. Fonseca JCF. Epidemiologia das hepatites B e Delta na região amazônica. Skopia 1988;23:28-32.

59. Fonseca JCF, Simonetti SRR, Schatzmyr HG, Castejón MJ, Cesario ALO, Simonetti JP. Prevalence of infection with Hepatitis Delta Virus (HDV) among carriers of hepatitis B surface antigen in Amazonas state. Trans Royal Society Trop Med and Hyg. 1988; 82:469-471.

60. Fonseca JCF, Brasil LM, Castilho MC, Braga WSM, Souza RAB, Ferreira LCL. Hepatitis Delta Virus (HDV) infectious in the Brazilian Amazon basin and its role in chronic liver disease. Hepatology. 1994; 19:63I-63.

61. Fonseca JCF. Hepatite Delta. Artigo de revisão. Rev. Soc. Bras. Med. Trop. 2002; 35 (2):181-190.

62. Fonseca JCF. História Natural da Hepatite crônica B. Artigo de revisão. Rev Soc Bras Med Trop. 2007; 40 (6):672-677.

63. Fonseca JCF. Histórico das hepatites virais. Rev Soc Bras Med Trop. 2010,43(3):322-330.

64. Funk ML, Rosenberg DM, Lok AS. World-wide epidemiology of HBeAg-negative chronic hepatitis B and associated precore and core promoter variants. Journal of Viral Hepatology. 2002; 9: 52-61.

65. Galizzi JF, Teixeira R, Fonseca JCF, Souto FJD. Clinical profile of hepatitis B virus chronic infection in patients of Brazilian liver reference units. Hepatol Int. 2010;4:511-515.

66. Ganem D, Prince AM. Hepatitis B virus infection-natural history and clinical consequences. N Engl J Med. 2004; 350:1118-29.

67. Garcia-Tsao G, Bosch J, Groszmann RJ. Portal hypertension and variceal bleeding - unresolved issues. Summary of an American Association for the study of liver diseases and European Association for the study of the liver single-topic conference. Hepatology 2008;47:1764-72.

68. Gayotto LCC, Alves VAF. Classificação histopatológica das hepatites virais crônicas. In: Focaccia R, editor; Grupo de hepatites virais do Instituto de Infectologia Emilio Ribas. Tratado de hepatites virais. 2. ed.São Paulo: Atheneu; 2007;623-626.

69. Gines P, Quintero E, Arroyo V, Teres J, Bruguera M, Rimola A, et al. Compensated cirrhosis: Natural history and prognostic factors. Hepatology $1987 ; 7: 122-8$. 
70. Gordan A, McLean CA, Pederson JS, Bailey MJ, Roberts SK. Hepatic steatosis in chronic hepatitis B and C: predictors, distribution and effect on fibrosis. J Hepatol. 2005;43:38-44.

71. Guidotti GG, Chisari FV. Noncytolytic control of viral infections by the innate and adaptive immune response. Annu. Rev. Immunol.2001;19:65-91

72. Hadziyannis SJ, Papatheodoridis GV. Hepatitis B e antigen-negative chronic hepatitis: natural history and treatment. Semin Liver Dis. 2006; 26:130-141.

73. Hadziyannis SJ. Natural history of chronic hepatitis B in Euro-Mediterranean and African Countries. J.Hepatol. 2011; 55:183-191.

74. Harpaz R, McMahon BJ, Margolis HS, Shapiro CN, Havron D, Carpenter G, et al. Elimination of new chronic hepatitis $B$ virus infections: results of the Alaska immunization program. J Infect Dis. 2000; 181:413-8.

75. Hatzakis A, Magiorkinis, E Haida C. HBV virological assessment. J Hepatol. 2006;44: 71-76.

76. Huo T-L, Wu J-C, Hwang S-J, Lai C-R, Lee P-C, Tsay S-H, Chang F-Y, Lee SD. Factors predictive of liver cirrhoses in patients with chronic hepatitis B: a multivariate analyses in a longitudinal study. Eur.J. Gastroenterol \& Hepatol. 2000, 12(6): 687-693.

77. IBGE [acesso em 14 de maio 2011]. Disponivel em: http://www.ibge.gov.br/home/estatistica/populacao/censo2000/universo.php?tipo=31 o/tabela13 1.shtm\&paginaatual $=1 \&$ uf $=12 \&$ letra=R

78. Iloeje UH, Yang HI, Jen CL, You SL, Chen CJ. Predicting cirrhosis risk based on the level of circulating hepatitis B viral load. Gastroenterol. 2006;130:678-686.

79. Infectious Disease Illustrations - RIT - People - [HomePage na internet].Figura hepatite B [acesso em 23 de março de 2011]. Disponivel em: http://people.rit.edu/japfaa/infectious.html.

80. Ishak KG, Baptista A, Bianch L, et al. Histological grading and staging of chronic hepatitis. J Hepatol. 1995; 22:696.

81. Jardi R, Rodrigues F, Butti M, Costa X, Cotrina M, Galiman R, Esteban R, Guardia J. Role of hepatitis $B, C$, and D viruses in dual and triple infection: influence of viral genotypes and hepatitis B precore and basal core promoter mutations on viral replicative interference. Hepatology. 2001,34: 404-410.

82. Jung MC, Spengler U, Schraut W, Hoffmann R, Zachoval R, Eisenburg J, Eichenlaub, D, Riethmuller G, Paumgartner G, Ziegler-Heitbrock HW. Hepatitis B virus antigen-specific T-cell activation in patients with acute and chronic hepatitis $B$. J.Hepatol. 1991;13:310-317.

83. Kao JH., Hepatitis B viral genotypes: clinical relevance and molecular characteristics. J Gastroenterol Hepatol 2002; 17:643-50.

84. Katsuragawa TH, Cunha RPA, Salcedo JMV, Souza DCA, Oliveira KRV, Gil LHS, Batista DP, Tada MS, Silva LHP. Alta soroprevalencia dos marcadores das hepatites B e C na região do alto rio Madeira, Porto Velho, Rondônia, Brasil. Ver Pan-Amaz Saud. 2010;1(2):91-96. 
85. Kato H, Orito E, Gish RG, Sugauchi F, Suzuki S, Ueda R, Miyakawa $Y$, Mizokami M. Characteristics of Hepatitis B Virus Isolates of Genotype $G$ and Their Phylogenetic Differences from the Other Six Genotypes (A through F). J Virol. 2002;76(12):6131-6137.

86. Kato H, Orito E, Gish RG, Bzowej N, Newsom M, Sugauchi F, Suzuki S, Ueda R, Miyakawa Y, Mizokami M. Hepatitis B e Antigen in Sera From Individuals Infected With Hepatitis B Virus of Genotype G.;35(4):922-929.

87. Keeffe EB, Dieterich DT, Han SB, Jacobson IM, Martin P, Schiff ER, et al. A treatment algorithm for the management of chronic hepatitis $B$ virus infection in the United States: an update. Clin Gastroenterol Hepatol 2006; 4:936-962.

88. Kidd-Ljunggren K, Miyakawa $\mathrm{Y}$, Kidd $\mathrm{AH}$. Genetic variability in hepatitis $\mathrm{B}$ viruses. J Gen Biology. 2002; 83: 1267-80.

89. Kiesslich D, Crispim MA, Santos C et al. Influence of hepatitis B vírus (HBV) genotype on the clinical course of disease in patients coinfected with HBV and hepatitis delta virus. J Infect Dis. 2009; 199:1608-1611.

90. Khouri ME, Santos VA. Hepatitis B: Epidemiological, immunological, and serological considerations emphasizing mutation. Rev Hosp Clin Fac Med S Paulo. 2004;59(4):216-224.

91. Knodell RG, Ishak GK, Black WC, Chen TS, Craig R, Kaplowitz N, Kiernan TW, Wollman J. Formulation and application of a numerical scoring system for assessing histological activity in asymptomatic chronic active hepatitis. Hepatol. 1981;1(5):431 435.

92. Lai CL, Yuen MF. The natural history of chronic hepatitis B. J Viral Hepatitis. 2007;14(1),6-10.

93. Lee CL, Ko YC. Hepatitis B vaccination and hepatocellular carcinoma in Taiwan. Pediatrics. 1997;99:351-353.

94. Lee HJ, Seo YS, Kim DJ, Kang HS, An H, Kim JH, Cheong JY, Yim HJ, Yeon JE, Lee HS, Byun KS, Cho SW, Kim DJ, Um SH, Kim CD, Ryu HS. Application of the HALF index obviates the need for liver biopsy in half of all patients with chronic hepatitis B. J Gastroenterol Hepatol. 2011;26:987-995.

95. Lee WM. Hepatitis B virus infection. N Engl J Med. 1997;337:1733-1745.

96. Liaw Y-F. Role of hepatitis $C$ virus in dual and triple hepatitis viral infection. Hepatol. 1995;22:1101-1108.

97. Liaw Y-F. Natural history of chronic hepatitis B virus infection and long-term outcome under treatment. Liver Internat. 2009;29(S1):100-107.

98. Liaw Y-F \& Chu C-M. Hepatitis B virus infection. Lancet. 2009;373:582-592.

99. Lin C-L, Kao J-H. Hepatitis B viral factores and clinical outcomes of chronic hepatitis B. J Biomed Sci. 2008,15:137-145.

100. Liu CJ, Chen BF, Chen PJ, Lai MY, Huang WL, Kao JH, et al. Role of hepatitis $B$ viral load and basal core promoter mutation in hepatocellular carcinoma in hepatitis B carriers. J Infect Dis. 2006;193:1258-1265.

101. Liu CJ, Chen BF, Chen PJ, Lai MY, Huang WL, Kao JH, et al. Role of hepatits $\mathrm{B}$ vírus precore/core promoter mutations and serum viral load on non- 
cirrhotic hepatocellular carcinoma: a case-controle study. J Infect Dis. 2006;194:594-599.

102. Lobato C, Messias CT, Messias KCS, Morais MA, Redon MH, Souza MS. Freqüência dos marcadores sorológicos dos virus da hepatite $B(\mathrm{VHC}), \mathrm{C}(\mathrm{VHC}), \mathrm{D}$ (VHD), e HIV em sete municipios do Estado do Acre, Anais do XVII Congresso Brasileiro de Hepatologia, Recife, 2003.

103. Lobato C, Dantas JL, Ferreira MJRM, Morais MA, Silva MMR, Freqüência dos marcadores sorológicos dos virus da hepatite B (VHB), C (VHC), D (VHD), e HIV em quatro pólos indígenas do Estado do Acre e Amazonas. Apresentação de forma ORAL no XVII Congresso Brasileiro de Hepatologia, Recife, 2003.

104. Lobato C, Tavares_Neto J, Rios_Leite M, Trepo C, Vitvitski L, Parvaz P, Zoulim F, D'Oliveira A Jr, Paraná R. Intrafamilial prevalence of hepatitis B virus in Western Brazilian Amazon region: Epidemiologic and biomolecular Study. J Gastroenterol Hepatol. 2006;21(5):

863-868.

105. Lok A.S.F., McMahon B.J. Chronic hepatitis B. Hepatology. 2007;45(2):507539.

106. Magnius LO, Norder H. Subtypes, genotypes and molecular epidemiology of the hepatitis B virus as reflected by sequence variability of the S-gene. Intervirology. 1995;38:24-34.

107. Mayerat C, Mantegani A, Frei PC. Does hepatitis B virus (HBV) genotype influence the clinical outcome of HBV infection? Journal of Viral Hepatology. 1999;6:299-304.

108. Ming L, Thorgeirsson SS, Gail MH, Lu P, Harris CC, Wang N, et al. Dominant role of hepatitis $B$ virus and cofactor role of aflotoxin in hepatocarcinigenesis in qidong, China. Hepatology 2002;36:1214-1220.

109. Ministério da Saúde: sala de situação em saúde-MS [acesso em 14 de maio de 2011]. Disponivel em:http://portal.saude.gov.br/portal/saude/default.cfm

110. Ministério da Saúde: Departamento de DST/HIVIAIDS e Hepatites [acesso em julho de 2011]. Disponivel em:http://portal.saude.gov.br/portal/saude/profissional/visualizar texto.cfm?idtxt=30 904 \&janela $=1$

111. Ministério da Saúde. Secretaria de Vigilância em Saúde. Programa Nacional de Imunizações 30 anos/Ministério da Saúde, Secretaria de Vigilância em Saúde Brasília, Brasil. Ministério da Saúde, 2003. 208 col.: il. - (Série C. Projetos e Programas e Relatórios). [acesso em 14 de maio de 2011]. Disponivel em http://portal.saude.gov.br/portal/arquivos/pdf/livro_30_anos_pni.pdf

112. Ministério da Saúde. O Brasil está atento, $3^{\circ} \mathrm{ed}$. Secretaria de Vigilância em Saúde - Departamento de DST/HIVIAIDS e Hepatites. Brasilia: Ministerio da Saude, 2008.

113. Ministério da Saúde. Protocolo Clínico e Diretrizes Terapêuticas para o Tratamento da Hepatite Viral Crônica B e Coinfecções. In: Secretaria de Vigilância em Saúde - Departamento de DST/HIVIAIDS e Hepatites. Brasilia: Ministerio da Saude, 2010.132 p.: il. - (Serie A. Normas e Manuais Tecnicos). 
114. Neves MV. História Nativa do Acre. [acesso em Maio de 2011]. Disponivel http://eduardoeginacarli.blogspot.com/2011/03/historia-nativa-do-acre-por-marcos.html

115. Nguyen LH, Ko S, Wong SS, Tran PS, Trinh HN, Garcia RT, Ahmed A, Lutchman GA, Keeffe EB, Nguyen MH. Ethnic differences in viral dominance patterns in patients with hepatitis B virus and hepatitis $C$ virus dual infection. Hepatol. 2011;53:1839-1845.

116. Niro, G. A. et al. Intrafamilial transmission of hepatitis delta virus: molecular evidence. J. Hepatol. 1999;30:564-569.

117. Norder H., A.M. Courouce, and L.O. Magnius, Complete genomes, phylogenetic relatedness, and structural proteins of six strains of the hepatitis $B$ virus, four of which represent two new genotypes. Virology. 1994;198(2): 489-503.

118. Okamoto, H., et al., Typing hepatitis B virus by homology in nucleotide sequence: comparison of surface antigen subtypes. J Gen Virol. 1988;69(10):25752583.

119. Papatheodoridis GV, Cholongitas E, Dimitriadou E, Touloumi G, Sevastianos V, Archimandritis AJ. MELD vs Child-Pugh and creatinine-modified Child-Pugh score for predicting survival in patients with decompensated cirrhosis. World $\mathrm{J}$ Gastroenterol 2005; 11(20): 3099-3104 [acesso em 02 de fev 2008]. Disponível em: http://www.wignet.com/1007-9327/11/3099.asp.

120. Paraná R, Alan Kay, Pedro Tauil, Molinet Felix, Viana Sebastião, Luciano Kalabric Silva, Juan Miguel Salcedo, José Tavares-Neto, Cirley Lobato, Marcio Rios-Leite, Luciana Matteonni, Argemiro D'Oliveira Jr, e Christian Trepo: HDV Genotypes in the Western Brazilian Amazon Region a Preliminary Report. Am. J. Trop. Med. Hyg. 2006; 75(3): 475-479.

121. Paraná R, Almeida D. HBV epidemiology in Latin America. J Clin Virol. 2005;34(1)S130-133.

122. Park SH, Kim DJ, Cheong JY, Cho SW, Hwang SG, Lee YJ, Cho M, Yang JM, Kim YB. Noninvasive markers to diagnose cirrhosis in patients with $\mathrm{HBeAg}$ positive chronic hepatitis: Do new biomarkers improve the accuracy?. Clin Biochem. 2010; 43:877-881.

123. Perz JF, Armstrong GL, Farrington LA, Hutin YJ, Bell BP. The contribution of hepatitis $B$ virus and hepatits $C$ virus infections to cirrhosis and primary liver cancer wordwide. J Hepatol. 2006;45:529-538.

124. Pontisso P, Gerotto M, Ruvoletto MG, Fattovich G, Chemello L, Tisminetzky $\mathrm{S}$, Baralle F, Alberti A. Hepatitis C genotypes in patients with dual hepatitis B and C virus infection. J Med Virol. 1996;47:157-160.

125. Poovorawan Y, Chongsrisawat V, Theamboonlers A, Leroux-Roels G, Kuriyakose S, Leyssen M, Jacquet J-M. Evidence of protection against clinical and chronic hepatitis B infection 20 years after infant vaccination in a high endemicity region. J Vir Hepat. 2011;18:369-375.

126. Pratt DS, Kaplan MM. Evaluation of abnormal liver enzyme results in asymptomatic patients. N Engl J Med. 2000; 342(17)1266-1271.

127. Puoti M, Torti C, Bruno R, Filice G, Carosi G. Natural history of chronic hepatitis B in co-infected patients. J Hepatol. 2006;44:S65-S70. 
128. Quintero A, Uzcátegui N, Loureiro CL, Villegas L, Illarramendi X, Guevara ME, Ludert JE, Blitz L, Liprandi F, Pujol FH. Hepatitis delta virus genotypes I and III circulate associated with hepatitis B virus genotypes F in Venezuela. J. Med. Virol. 2001,64:356-359.

129. Rantala AO, Lilja M, Kauma H, Savolainen MJ, Reunanen A, Kesänjemi YA. Gamma-glutamyl-transpeptidase and the metabolic syndrome. J Intern Med. 2000,248(3):230-238.

130. Rapicetta M, Ferrari C, Levrero M. Viral determinants and host immune responses in the pathogenesis of HBV infection. J Med Virol. 2002;67:454-457

131. Rezende RE, Fonseca BA, Ramalho LN, Zucoloto S, Pinho JR, Bertolini DA, Martinelli AL. The precore mutation is associated with severity of liver damage in Brazilian patients with chronic hepatitis B. J. Clin Virol. 2005;32: 53-9.

132. Rizzetto M. Hepatitis delta: the virus and disease. J Hepatol. 1990;11: S145S148.

133. Rizzetto, M. Hepatitis D: virology, clinical and epidemiological aspects. Acta Gastroenterol. Belg. 2000,63:221-224.

134. Rizzetto M, Ciancio A. Chronic HBV-related liver disease. Molecul Aspects of Medicine. 2008,29:72-84.

135. Rizzetto M. Hepatitis D:Thirty years after. J.Hepatol. 2009, doi:10.1016/j.jhep.2009.01.004

136. Romeo R, Ninno E, Rumi M, Russo A, Sangiovanni A, de Franchis R, Ronchi G, Colombo M. A 28-year study of the course of hepatitis delta infection: a risk factor for cirrhosis and hepatocellular carcinoma. Gastroenterology 2009,136:1629-1638.

137. Ruiz-Moreno M, Otero M, Millán A, Castillo I, Cabrerizo M, Jimènez FJ, et al. Clinical and histological outcome after hepatitis $B$ e antigen to antibody seroconversion in children with chronic hepatitis B. Hepatol. 1999;29:572-575.

138. Sagnelli E, Coppola N, Scolastico C, Filippini P, Santantonio T, Stroffolini T, Piccinino F. Virologic and clinical expressions of reciprocal inhibitory effect of hepatitis B, C, and delta viruses in patients with chronic hepatitis. Hepatology.2000, 32: 1106-1110.

139. Salehi-Ashtiani K, Luptak A, Litovchick A, Szostak JW. A genome wide search for ribozymes reveals an HDV-like sequence in the human CPEB3 gene. Science 2006;313:1788-1792.

140. Sanchez-Tapias JM, Costa J, Mas A, Bruguera M, Rodes J. Influence of hepatitis $B$ virus genotypes on the long-term outcome of chronic hepatitis $B$ in Western patients. Gastroenterol. 2002;123:1848-1856.

141. Schaefer S. Hepatitis B virus taxonomy and hepatitis B virus genotypes. W J Gastroenterol. 2007;13(1): 14-21.

142. Secretaria Municipal de Saúde do Acre. [Acesso em 14 de maio de 2011].Disponivel em: (http://dab.saude.gov.br/historico cobertura sf/historico cobertura sf relatorio.php)

143. Secretaria Municipal de Saúde do Acre [acesso em 12 de maio de 2011]. Disponivel 
http://www.riobranco.ac.gov.br/v4/images/stories/downloads/SEMSARELATRIO A. GESTO 2008 1.04.09 REVISADO.pdf

144. Sheen I-S, Liaw Y-F, Lin D-Y, Chu M-C. Role of hepatitis $C$ and delta viruses in the termination of chronic hepatitis $B$ surface antigen carrier state: A multivariate analysis in a longitudinal follow-up study. J. Infect.Dis. 1994; 170:358-361.

145. Shimuzu I, Kohno N, Tamaki K, Shono M, Huang HW, He JH, Yao DF. Female hepatology: Favorable role of estrogen in chronic liver disease with hepatitis B virus infection. World J. Gastroenterol. 2007, 13(32):4295-4305.

146. Sociedade Brasileira de Infectologia. I Consenso da Sociedade Brasileira de Infectologia para o Diagnóstico e Manuseio da Hepatite B (e Delta). The Brazilian J Infect Disease. 2006; 10 (suppl.1):2-28.

147. Sociedade Brasileira de Hepatologia. Consenso sobre condutas nas hepatites virais B e C. 2005. [acesso em 17 de junho de 2011]. Disponivel em http://www.sbhepatologia.org.br/pdf/consensos/consenso redacao final b.pdf.

148. Souto FJ, Fontes DJ, Gaspar AM, Lyra LG. hepatitis B virus infection in immigrants to the southem Brazilian Amazon. Trans R Soc Trop Med Hyg. 1998;92(3):282-284.

149. Souza M.G., Passos A.D., Machado A.A., et al. HIV and hepatitis B virus coinfection: prevalence and risk factors. Rev Soc Bras Med Trop. 2004;37(5):391-5.

150. Souza CAA. História do Acre: Novos temas, Nova Abordagem. Rio Branco,

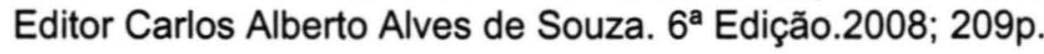

151. Stuyver L., DeGendt S, VanGeyt C, Zoulim F, Fried M., Schinazi RF, Rossau R. A new genotype of hepatitis B virus: complete genome and phylogenetic relatedness. J Gen Virol. 2000; 81(1): 67-74.

152. Su C-W, T Huang Y-H, Huo T-A, Shih HH, Sheen I-J, Chen S-W, Lee P-C, Lee $S-D, W u$ J-C. Genotypes and viremia of hepatitis $B$ and $D$ viruses are associated with outcomes of chronic hepatitis D patients. Gastroenterology 2006,130:1625-1635.

153. Sukugawa $H$, Nakayoshi $T$, Kobashigawa $K$, Nakasone $H$, Kawakami $Y$, Yamashiro T, et al. Metabolic syndrome is directely associated with gamma glutamyl transpeptidase elevation in Japanese women. World J Gastroenterol. 2004, 10(7) 1052-1055.

154. Thakur V, Guptan RC, Kazim SN, Malhotra V, Sarin SK. Profile, spectrum and significance of HBV genotypes in chronic hepatitis liver disease patients in the Inian subcontinent. J Gastroenterol Hepatol. 2002;17:165-170.

155. Thomopoulos KC, Arvaniti V, Tsamantas AC, Dimitropoulou D, Gogos CA, Siagres D. Prevalence of liver steatosis in patients with chronic hepatitis B: a study of associated factors and of relationship with fibrosis. Eur J Gastroenterol Hepatol. 2006;18:233-237.

156. Tonetto PA, Gonçales NSL, Fais VC, Vigani AG, Gonçales ESL, Feltrin A, et al. Hepatitis B virus: molecular genotypes and $\mathrm{HBeAg}$ serological status among HBVinfected patients in the southeast of Brazil. BMC Infect Dis 2009; 9:149-156. 
157. Viana S, Paraná R,Moreira RC, Compri AP, Macedo.High prevalence of hepatitis $B$ and hepatitis $D$ virus in th Western Brazilian Amazon. Am. J. Trop. Med. Hyg. 2005;73(4):808-814.

158. Victória FS, Oliveira CMC, Victória MB, Ferreira LCL. Characterization of $\mathrm{HBeAg}$ negative chronic B in Western Brazilian Amazonia. Braz J Infect Dis [on line] 2008;12(1):27-37. [acesso em 17 de junho de 2011]. Disponivel. $<$ http://www.scielo.br/scielo.php?script=sci_arttext\&pid=S1413-86702008000100008\&lng $=e n \& n r m=i s o>$. ISSN $1413-8670$. doi: 10.1590/S1413-86702008000100008.

159. Wai CT, Chu $\mathrm{CH}$, Hussain M, Lok AS. HBV genotype $B$ is associated with better response to interferon therapy in $\mathrm{HBeAg}(+)$ chronic hepatitis than genotype C. Hepatology. 2002;36:1425-1430.

160. Wong WC, Tsang KK. A mass hepatitis B vaccination programme in Taiwan: its preparation, results and reasons for uncompleted vaccinations. Vaccine.1994;12:229-234.

161. World Health Organization (WHO). Hepatitis B .2002,2:1-76 [acesso em 24 de novembro de 2009]. Disponivel. http://www.who.int/csr/disease/hepatitis/HepatitisB_whocdscsrlyo2002_2.pdf

162. World Health Organization. Hepatitis B vaccines. WHO website; 2003. [acesso em 24 de novembro de 2009]. Disponivel http://www.who.int/vaccines/en/hepatitisb.shtml.

163. Wu J-C, Lee S-D, Govindarajan S, Kung T-W, Tsai Y-T, Lo K-J, Ting L-P. Correlation of serum delta RNA with clinical course of acute hepatitis delta virus superinfection in Taiwan: A longitudinal study. J. Infec Diseas. 1990;161(6):11161120.

164. Yang HI, Lu SN, Liaw YF, You SL, Sun CA, Wang LY, et al. Hepatitis B e antigen and the risk of hepatocellular carcinoma. N Engl J Med. 2002;347:168-174.

165. Yang PM, Huang GT, Lin JT, Sheu JC, Lai MY, Su IJ, et. al. Ultrasonography in the diagnosis of benign diffuse parenchymal liver disease: a prospective study. $J$ Formosan Med Assoc 1988;87:966-977.

166. Yuen M-F, Lai C-L. Treatment of chronic hepatitis B: Evolution over two decades. J Gastroenterol Hepatolol. 2011;26(1)138-143.

167. Yu MW, Chang HC, Liaw YF, Lin SM, Lee SD, Liu CJ. Familial risk of hepatocellular carcinoma among chronic hepatitis B carriers and their relatives. $J$ Natl Cancer Inst. 2000;92:1159-1164.

168. Yu MW, Yeh SH, Chen PJ, Liaw YF, Lin CL, Liu CJ, et al. Hepatitis B virus genotype and DNA level and hepatocellular arcinoma: a prospective study in men. $J$ Natl Cancer Inst. 2005;97:265-272.

169. Yurdaydın C., Idilman R., Bozkaya1 H. and Bozdayi A. M. Natural history and treatment of chronic delta hepatitis. J of Viral Hepatitis, 2010; 17: 749-756.

170. Ucmak H, Kokoglu OF, Celik M, Ergun UGO. Intra-familial spread of hepatitis $B$ virus infection in eastern Turkey. Epidemiol Infect. 2007;135:1338-1343.

171. Zago AM, Machado TF, Cazarim FL, Miranda AE. Prevalence and Risk Factors for Chronic Hepatitis B in HIV Patients Attended at a Sexually-Transmitted Disease Clinic in Vitoria, Brazil. Braz J Infect Dis. 2007;11(5):475-478. 


\section{Apêndice 1}

(Anexoili)

\section{TERMO DE RESPONSABILIDADE DO PESQUISADOR}

Eu, Cirley Maria de Oliveira Lobato, pesquisadora responsável pelo projeto de pesquisa intitulado Aspectos epidemiológicos e prognósticos da hepatite B crônica na Amazônia Ocidental assumo a responsabilidade de comunicar imediatamente ds Instituiçōes: Serviço de Assistência Especializada-SAE - SESACRE, Universidade Federal do Acre e Faculdade de Saúde Pública - Universidade de São Paulo toda e qualquer complicacão ocomida durante a realização do referido projeto que coloque em risco o voluntário ou bens incluidos neste trabalho de pesquisa.

Responsabilizo-me, iguaimente, a acompanhar as diligências necessárias à imediata e integral assistência aos voluntários participantes ou à reposição ou restauração de bens eventualmente danificados durante a pesquisa.

Rio Branco, 28 de Agosto de 2008

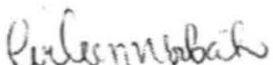

Cirley Maria de Oliveira Lobato

Pesquisadora 


\section{Apêndice 2.}

\section{Aspectos epidemiológicos da hepatite $B$ e fatores prognósticos da cirrose em pacientes com hepatite B crônica na Amazônia Ocidental}

Instrumento de Coleta (Confidencial)

Data do registro das informações nesta ficha:

Médico responsável:

\begin{tabular}{|c|c|c|}
\hline \multicolumn{3}{|c|}{ 1. IDENTIFICACCAO DO PACIENTE } \\
\hline 1 & $\begin{array}{l}\text { Nome da instituiçăo } \\
\text { SAE }\end{array}$ & (HBAO001) \\
\hline 2 & Identificação do paciente (número de identificação) & (HBAO002) \\
\hline 3 & $\mathrm{~N}^{\circ}$ do prontuário & (HBAO003) \\
\hline 4 & Nome da mãe do paciente & (HBAO004) \\
\hline 5 & Data de Nascimento (dd/mm/aaaa): __________ & $\begin{array}{c}\text { (HBAO005) } \\
\text { I_I_I_I_I_L_I }\end{array}$ \\
\hline 6 & Município de Nascimento & (HBAO006) \\
\hline 7 & Estado de Nascimento & $\begin{array}{l}\text { (HBAO007) } \\
\perp \perp \perp|+|\end{array}$ \\
\hline 8 & $\begin{array}{l}\text { Pais de Nascimento } \\
\text { Brasil }\end{array}$ & (HBAO008) \\
\hline 9 & Idade (no momento da primeira avaliação) (em anos): & (HBAO009) \\
\hline 10 & $\begin{array}{l}\text { Sexo: } \\
\begin{array}{lll} & \\
\text { (0) Masculino } & \text { (1) Feminino } & \text { (9) Ignorado }\end{array}\end{array}$ & $\begin{array}{ll}(\mathrm{HBAOO} 10) \\
\mid\end{array}$ \\
\hline 11 & Escolaridade (em anos completos de estudo formal): & (HBAO011) I_L_ \\
\hline \multicolumn{3}{|c|}{ II. INFORMACCOEES GERAIS-PRIMEIRA CONSULTA } \\
\hline 12 & $\begin{array}{l}\text { Estado civil atuai: } \\
\begin{array}{ll}\text { ( } 0) \text { Solteiro } & \text { ( } 1 \text { ) Casado } \quad \text { ( } 2 \text { ) Viúvo } \\
\text { (3) Divorciado/Desquitado/Separado } \\
\text { (4) Outros } & \text { ( } 9 \text { ) Ignorado }\end{array}\end{array}$ & الــHBA012) \\
\hline 13 & Endereço da residência atual (data do preenchimento desta ficha): & (HBAO013) \\
\hline 14 & Bairro da residência atual: & (HBAO014) \\
\hline 15 & CEP da residência atual: & (HBAO015) \\
\hline 16 & Município da residência atual: & (HBA0016) \\
\hline 17 & Estado da residência atual & (HBAO017) \\
\hline 18 & $\begin{array}{c}\text { País da residência atual } \\
\text { Brasil }\end{array}$ & (HBAO018) \\
\hline
\end{tabular}




\begin{tabular}{|c|c|c|}
\hline 19 & Telefone atual: $(\quad)$ & (HBAO019) \\
\hline 20 & Ocupação & (HBAO020) \\
\hline 21 & $\begin{array}{l}\text { Tipo de trabalho } \\
\begin{array}{lll} & & \\
\text { (0) Trabalho intelectual } & (1) \text { Trabalho braçal } & \text { (9) Ignorado }\end{array}\end{array}$ & (HBAO021) \\
\hline 22 & $\begin{array}{l}\text { Raça e etnia referida } \\
\begin{array}{lllll}\text { (1) Branco } & \text { (2) Negro } & \text { (3) Indigena } & \text { (4) Pardo } & \text { (9) Outra }\end{array}\end{array}$ & (HBAO022) \\
\hline & III. DADOS EPIDEMIOLOGICOS & \\
\hline 01 & Data do diagnóstico da hepatite $\mathrm{B}:$ & 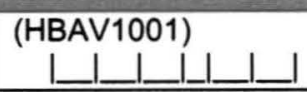 \\
\hline $01 \mathrm{~A}$ & Em qual serviço médico foi feito o diagnóstico de hepatite $B$ ? & (HBAV1001A) \\
\hline 01B & Data da primeira consulta no serviço (dd/mm/aaaa): ___ & 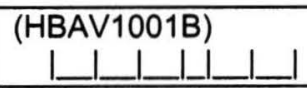 \\
\hline $01 \mathrm{C}$ & $\begin{array}{l}\text { Quantas consultas teve no decorrer do acompanhamento? } \\
\text { Número de consulta }\end{array}$ & $\begin{array}{l}\text { HBAV1001C) } \\
\text { HBA }\end{array}$ \\
\hline 02 & Idade à época do diagnóstico da hepatite (em anos): & ${ }^{(\text {HBAV1002) }}$ \\
\hline 03 & $\begin{array}{l}\text { Modo potencial de contágio? } \\
\begin{array}{lll}\text { (0) Năo } & \text { (1) Sim } & \text { (8) Não se aplica }\end{array}\end{array}$ & (HBAV1003) \\
\hline 03A & $\begin{array}{l}\text { Sexual } \\
\begin{array}{lll}\text { (0) Não } & \text { (1) Sim } & \text { (8) Não se aplica }\end{array}\end{array}$ & (HBAV1003A) \\
\hline $03 \mathrm{~B}$ & $\begin{array}{lll}\begin{array}{l}\text { Parenteral } \\
\text { (0) Não }\end{array} & \text { (1) Sim } & \text { (8) Não se aplica } \\
\end{array}$ & (HBAV1003B) \\
\hline $03 \mathrm{C}$ & (1) Sim (8) Não se aplica & (HBAV1003C) \\
\hline $03 \mathrm{D}$ & $\begin{array}{lll}\begin{array}{l}\text { Ocupacional } \\
\text { (0) Não }\end{array} & \text { (1) Sim } & \text { (8) Não se aplica } \\
\end{array}$ & (HBAV1003D) \\
\hline $03 \mathrm{E}$ & $\begin{array}{l}\text { Intra-familiar } \\
\begin{array}{lll}\text { (0) Não } & \text { (1) Sim } & \text { (8) Não se aplica }\end{array}\end{array}$ & (HBAV1003E) \\
\hline 04 & $\begin{array}{l}\text { Grupo de exposição Específica? } \\
\begin{array}{lll}\text { (0) Não } & (1) \operatorname{Sim} & (9) \text { Ignorado }\end{array}\end{array}$ & (HBAV1004) \\
\hline $04 \mathrm{~A}$ & $\begin{array}{l}\text { Profissional do sexo } \\
\begin{array}{llll}\text { (0) Não } & \text { (1) Sim } & \text { (8) Não se aplica } & \text { ( } 9 \text { ) Ignorado }\end{array}\end{array}$ & (HBAV1004A) \\
\hline 04B & $\begin{array}{l}\text { Droga EV } \\
\begin{array}{llll}\text { (0) Não } & \text { (1) Sim } & \text { (8) Não se aplica } & \text { ( } 9) \text { Ignorado }\end{array}\end{array}$ & (HBAV1004B) \\
\hline $04 \mathrm{C}$ & $\begin{array}{l}\text { Profissional de saúde } \\
\begin{array}{llll}\text { (0) Não } & \text { (1) Sim } & \text { (8) Não se aplica } & (9) \text { Ignorado } \\
\end{array}\end{array}$ & (HBAV1004C) \\
\hline 04D & $\begin{array}{l}\text { Em que setor do serviço de saúde você trabalha ou trabalhou } \\
\text { (1) Ambulatório (2)Enfermaria (3)Emergência (4)Centro cirúrgico } \\
\text { (5)Laboratório (6)Hemodiálise (7) Outro (8) Não se aplica (9) Ignorado }\end{array}$ & $\begin{array}{l}\text { (HBAV1004D) } \\
\perp+\end{array}$ \\
\hline 04E & $\begin{array}{l}\text { Qual ocupação que você tem ou tinha no serviço de saúde? } \\
\begin{array}{lll}\text { (1) Médico(a) (2) Enfermeiro (a) (3) Auxiliar de enfermagem } \\
\text { (4) Odontólogo (5) Atividades de laboratório } & \text { (6) Serviço de limpeza } \\
\text { (7) Serviço administrativo (8) Outro (9) Não se aplica } & \end{array}\end{array}$ & $\begin{array}{l}\text { (HBAV1004E) } \\
\perp \perp\end{array}$ \\
\hline $04 \mathrm{~F}$ & $\begin{array}{l}\text { Tatuagem, piercing. } \\
\begin{array}{llll}\text { (0) Não } & \text { (1) Sim } & \text { (8) Não se aplica } & \text { (9) Ignorado }\end{array}\end{array}$ & (HBAV1004F) \\
\hline 04G & $\begin{array}{l}\text { Hemodiálise } \\
\begin{array}{lll}\text { (0) Não } & \text { (1) Sim } & \text { (8) Não se aplica }\end{array}\end{array}$ & (HBAV1004G) \\
\hline $04 \mathrm{H}$ & $\begin{array}{l}\text { Transfusões de sangue e hemoderivados } \\
\begin{array}{llll}\text { (0) Não } & \text { (1) Sim } & \text { (8) Não se aplica } & \text { ( } 9) \text { Ignorado }\end{array}\end{array}$ & (HBAV100H) \\
\hline 041 & $\begin{array}{l}\text { Compartilha (ou) escova de dente com outras pessoas? } \\
\begin{array}{llll}\text { (0) Não } & \text { (1) Sim } & \text { (8) Não se aplica } & \text { (9) Ignorado }\end{array} \\
\end{array}$ & ${ }^{(\text {HBAV1004I) }}$ \\
\hline $04 \mathrm{~J}$ & $\begin{array}{l}\text { Compartilha (ou) objetos cortantes (tesoura, lâmina de barbear, navalha, } \\
\text { alicate) com outras pessoas em casa ou em salōes de beleza (manicure, } \\
\text { pedicure, etc)? } \\
\begin{array}{llll}\text { (0) Não } & \text { (1) Sim } & \text { (8) Não se aplica } & \text { (9) Ignorado }\end{array}\end{array}$ & (HBAV1004J) \\
\hline
\end{tabular}




\begin{tabular}{|c|c|c|}
\hline $04 \mathrm{~L}$ & $\begin{array}{l}\text { Fez tratamento dentário alguma vez na sua vida? } \\
\begin{array}{llll}\text { (0) Não } & \text { (1) Sim } & \text { (8) Não se aplica } & \text { (9) Ignorado }\end{array} \\
\end{array}$ & (HBAV1004L) \\
\hline $04 \mathrm{M}$ & $\begin{array}{l}\text { Fez transfusão de sangue, derivados ou uso de imunoglobulina nos últimos } \\
12 \text { meses? } \\
\begin{array}{llll}\text { (0) Não } & \text { (1) Sim } & \text { (8) Não se aplica } & \text { (9) Ignorado }\end{array}\end{array}$ & 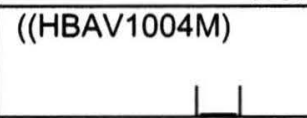 \\
\hline $04 \mathrm{~N}$ & $\begin{array}{l}\text { Fez cirurgia nos últimos } 12 \text { meses? } \\
\begin{array}{llll}\text { ( } 0) \text { Não } & \text { (1) Sim } & \text { (8) Não se aplica } & \text { ( } 9 \text { ) Ignorado }\end{array}\end{array}$ & (HBAV1004N) \\
\hline 040 & $\begin{array}{l}\text { Fez cirurgia alguma vez na sua vida? } \\
\begin{array}{llll}\text { (0) Não } & \text { (1) Sim } & \text { (8) Não se aplica } & \text { ( } 9 \text { ) Ignorado }\end{array}\end{array}$ & (HBAV1004O) \\
\hline $04 \mathrm{P}$ & $\begin{array}{l}\text { Há quantos anos fez a última cirurgia? } \\
\begin{array}{lll}\text { Em Anos } & \text { (8) Não se aplica } & \text { (9) Não sabe informar }\end{array}\end{array}$ & $\begin{aligned}(\text { HBAV1004P) } \\
\text { L__ll }\end{aligned}$ \\
\hline $04 Q$ & $\begin{array}{l}\text { Fez transfusão de sangue, derivados ou uso de imunoglobulina alguma vez } \\
\text { na sua vida? } \\
\begin{array}{llll}\text { (0) Não } & \text { (1) Sim } & \text { (8) Não se aplica } & \text { (9) Ignorado }\end{array}\end{array}$ & (HBAV1004Q) \\
\hline $04 R$ & $\begin{array}{l}\text { Há quantos anos fez a primeira transfusão de sangue, derivados ou uso de } \\
\text { imunoglobulina? } \\
\begin{array}{lll}\text { anos } & \text { (8) Não se aplica } & \text { (9) Não sabe informar }\end{array}\end{array}$ & (HBAV1004R) \\
\hline 05 & $\begin{array}{l}\text { Você já iniciou sua vida sexual (transou)? } \\
\begin{array}{llll}\text { (0) Não } & \text { (1) Sim } & \text { (8) Não se aplica } & \text { ( } 9 \text { ) Ignorado }\end{array}\end{array}$ & (HBAV1005) \\
\hline $05 \mathrm{~A}$ & Quantos anos você tinha quando teve a primeira relação sexual? & (HBAV1005A) \\
\hline 05B & $\begin{array}{l}\text { Você ou o seu (sua) parceiro(a) tem o hábito de usar camisinha? } \\
\begin{array}{llll}\text { (0) Não usa } & \text { (1) Sim, usa regularmente } & \text { (2) Sim usa às vezes } \\
\text { (8) Não se aplica } & \text { (9) Não informou } & \end{array}\end{array}$ & (HBAV1005B) \\
\hline $05 \mathrm{C}$ & $\begin{array}{l}\text { Seu (sua) parceiro (a) atual tem ou já teve hepatite? } \\
\begin{array}{llll}\text { (0) Não } & (1) \text { Sim } & \text { (8) Não se aplica } & \text { (9) Ignorado }\end{array}\end{array}$ & (HBAV1005C) \\
\hline $05 \mathrm{D}$ & $\begin{array}{l}\text { Você já teve outro(a) parceiro(a) sexual além do seu parceiro atual? } \\
\begin{array}{llll}\text { (0) Não } & \text { (1) Sim } & \text { (8) Não se aplica } & \text { (9) lgnorado }\end{array}\end{array}$ & (HBAV10045D) \\
\hline $05 \mathrm{E}$ & Quantos parceiros (as) sexuais você teve nos últimos 12 meses? & (HBAV1005E) \\
\hline $05 \mathrm{~F}$ & $\begin{array}{l}\text { Você já manteve relações sexuais com parceiro (a) sabidamente portador de } \\
\text { Hepatite? } \\
\begin{array}{llll}\text { (0) Não } & \text { (1) Sim } & \text { (8) Não se aplica } & \text { (9) Ignorado }\end{array}\end{array}$ & (HBAV1005F) \\
\hline 05G & $\begin{array}{l}\text { Você sabe se algum de seus (suas) parceiros (as) teve alguma doença } \\
\text { venérea? } \\
\begin{array}{llll}\text { (0) Não } & \text { (1) Sim } & (8) \text { Não se aplica } & \text { (9) lgnorado }\end{array}\end{array}$ & (HBAV1005G) \\
\hline $05 \mathrm{H}$ & $\begin{array}{l}\text { Você mantém ou já manteve relação sexual com parceiro (a) que faz sexo } \\
\text { com pessoa do mesmo sexo? } \\
\begin{array}{lllll}\text { (0) Não } & \text { (1) Sim } & \text { (2) Não sabe } & \text { (8) Não se aplica } & \text { ( } 9) \text { lgnorado }\end{array}\end{array}$ & (HBAV1005H) \\
\hline 051 & $\begin{array}{l}\text { 4. Você já teve alguma doença venérea (sífilis, gonorréia) ? (0) Não } \\
\begin{array}{llll}\text { Sim } & \text { (8) Não se aplica } & (9) \text { Ignorado }\end{array}\end{array}$ & (HBAV1005I) \\
\hline $06 \mathrm{~A}$ & $\begin{array}{l}\text { Você já fez uso de drogas fumadas? } \\
\begin{array}{llll}\text { (0) Não } & \text { (1) Sim } & \text { (8) Não se aplica } & \text { (9) Ignorado }\end{array}\end{array}$ & (HBAV1006A) \\
\hline $06 \mathrm{~B}$ & $\begin{array}{l}\text { Você já fez uso de drogas cheiradas? } \\
\begin{array}{llll}\text { (0) Não } & \text { (1) Sim } & \text { (8) Năo se aplica } & \text { (9) Ignorado }\end{array}\end{array}$ & (HBAV1006B) \\
\hline $06 \mathrm{C}$ & $\begin{array}{l}\text { Qual droga cheirada você fez uso? } \\
\begin{array}{llll}\text { (1) cocaina } & \text { (2) Lança perfume ou loló } & \text { (3) Acetona e removedores } \\
\text { (acetona) (4) Tintas e diluentes (thinner, etc) (5) Odorizantes de ambientes, } \\
\text { spray fixador de cabelos e desodorantes } & \text { (6) Heroina e crack } & \text { (7) outros } \\
\text { (8) Não se aplica }^{\text {(9) Não informou }} & & \end{array}\end{array}$ & (HBAV1006C) \\
\hline 06D & $\begin{array}{l}\text { Você já fez uso de drogas injetáveis? } \\
\begin{array}{llll}\text { (0) Não } & \text { (1) Sim } & \text { (8) Não se aplica } & \text { (9) Não sabe informar }\end{array}\end{array}$ & (HBAV1006D) \\
\hline $06 \mathrm{E}$ & $\begin{array}{l}\text { Você já tomou injeção com seringa de vidro ou compartilhou seringa? } \\
\begin{array}{llll}\text { (0) Não } & \text { (1) Sim } & \text { (8) Não se aplica } & \text { (9) Não sabe informar }\end{array}\end{array}$ & (HBAV1006E) \\
\hline $06 \mathrm{~F}$ & $\begin{array}{l}\text { Qual o motivo de ter tomado injeção com seringa de vidro ou ter } \\
\text { compartilhado seringa? } \\
\begin{array}{ll}\text { (1) Estimulante para prática de esportes } & \text { (2) Vitaminas e/ou glicose em }\end{array}\end{array}$ & (HBAV1006F \\
\hline
\end{tabular}




\begin{tabular}{|c|c|c|}
\hline & $\begin{array}{l}\text { farmácia (3) Orientação médica (4) Outros (especificar: } \\
\text { (8) Não se aplica (9) Não sabe informar }\end{array}$ & I I \\
\hline $06 \mathrm{G}$ & $\begin{array}{l}\text { Já recebeu vacina contra hepatite B? } \\
\begin{array}{llll}\text { (0) Não } & \text { (1) Sim } & \text { (8) Não se aplica } & \text { ( } 9) \text { Ignorado }\end{array}\end{array}$ & (HBAV1006G) \\
\hline $06 \mathrm{H}$ & 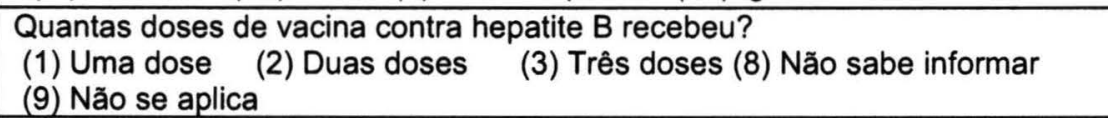 & (HBAV1006H) \\
\hline 061 & $\begin{array}{l}\text { Ficou hospitalizado para tratamento clínico nos últimos } 12 \text { meses? } \\
\begin{array}{llll}\text { (0) Não } & \text { (1) Sim } & \text { (8) Não se aplica } & \text { (9) Ignorado }\end{array}\end{array}$ & (HBAV1006I) \\
\hline $06 \mathrm{~J}$ & $\begin{array}{l}\text { Ficou hospitalizado para tratamento clínico (não cirúrgico) alguma vez na sua } \\
\text { vida? } \\
\begin{array}{llll}\text { (0) Não } & (1) \text { Sim } & (8) \text { Não se aplica } & \text { (9) Ignorado }\end{array}\end{array}$ & (HBAV1006J) \\
\hline $06 \mathrm{~L}$ & $\begin{array}{l}\text { Há quantos anos ficou hospitalizado para tratamento clínico (não cirúrgico)? } \\
\begin{array}{cll}\text { Anos } & \text { (8) Não se aplica } & \text { (9) Ignorado }\end{array} \\
\end{array}$ & $\begin{aligned} \text { (HBAV1006L) } \\
\text { L_I_LI }\end{aligned}$ \\
\hline 07 & $\begin{array}{l}\text { Fez endoscopia nos últimos } 12 \text { meses? } \\
\begin{array}{llll}\text { (0) Não } & \text { (1) Sim } & \text { (8) Não se aplica } & \text { ( } 9 \text { ) lgnorado }\end{array}\end{array}$ & (HBAV1007) \\
\hline 07A & $\begin{array}{l}\text { Fez endoscopia alguma vez na vida? } \\
\begin{array}{llll}\text { (0) Não } & \text { (1) Sim } & \text { (8) Não se aplica } & \text { (9) Ignorado }\end{array}\end{array}$ & (HBAV1007A) \\
\hline 08 & $\begin{array}{l}\text { Na sua vida inteira, você já tomou pelo menos } 8 \text { drinks (Por drink, eu quero } \\
\text { dizer meia cerveja, um copo de vinho ou uma dose de destilado (pinga, } \\
\text { whisky, etc.) de qualquer tipo de bebida alcoólica)? } \\
\begin{array}{llll}\text { (0) Não } & \text { (1) Sim } & \text { (8) Não se aplica } & \text { (9) Ignorado }\end{array}\end{array}$ & (HBAV1008) \\
\hline $08 \mathrm{~A}$ & $\begin{array}{l}\text { Já houve algum periodo na sua vida em que em um ano você tomou pelo } \\
\text { menos } 8 \text { drinks contendo álcool ? } \\
\begin{array}{llll}\text { (0) Não } & \text { (1) Sim } & \text { (8) Não se aplica } & \text { (9) Ignorado }\end{array}\end{array}$ & (HBAV1008A) \\
\hline 08B & $\begin{array}{l}\text { Durante os últimos } 30 \text { dias, você bebeu pelo menos uma dose de alguma } \\
\text { bebida alcoólica? } \\
\begin{array}{llll}\text { (0) Não } & \text { (1) Sim } & \text { (8) Não se aplica } & \text { (9) lgnorado }\end{array}\end{array}$ & (HBAV1008B) \\
\hline $08 \mathrm{C}$ & 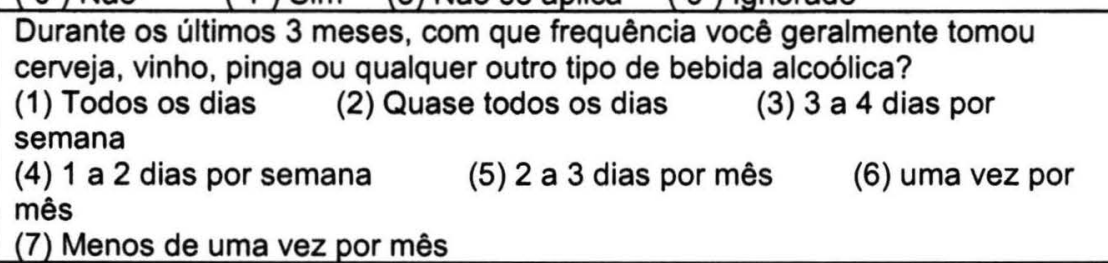 & (HBAV1008C) \\
\hline 08D & $\begin{array}{l}\text { Nos dias em que você bebeu nos últimos } 3 \text { meses quantos drinks você } \\
\text { geralmente tomou num único dia ? Por drink, eu quero dizer meia cerveja, um } \\
\text { copo de vinho ou uma dose de destilado (pinga, whisky, etc.)? }\end{array}$ & (HBAV1008D) \\
\hline $08 \mathrm{E}$ & $\begin{array}{l}\text { Você está atualmente em tratamento para um problema com o álcool (e } \\
\text { droga)? } \\
\begin{array}{llll}\text { (0) Não } & \text { (1) Sim } & \text { (8) Não se aplica } & \text { (9) lgnorado }\end{array}\end{array}$ & $\begin{array}{l}\text { (HBAV1008E) } \\
\perp+\end{array}$ \\
\hline $08 \mathrm{~F}$ & $\begin{array}{l}\text { A classificação quanto ao uso de bebida alcoólica (preenchido } \\
\text { posteriormente) } \\
\begin{array}{llll}\text { (1) Abstêmio } & \text { (2) Bebedor leve (Para homens, o produto da questão } 08 \mathrm{C} \\
\text { pela } 08 \mathrm{D} \text {, menor que } 21 \text { e mulher menor de } 14) & \text { (3) Bebedor pesado (Para } \\
\text { homens, o produto da questão } 08 \mathrm{C} \text { pela } 08 \mathrm{D} \text {, maior ou igual a } 21 \text { e mulher } \\
\text { maior ou igual a 14) (4) Dependente do álcool (Caso tenha respondido sim na } \\
\text { questão 08E) } & & \end{array}\end{array}$ & (HBAV1008F) \\
\hline 09 & Data do exame (dd/mm/aaaa): & 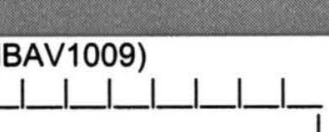 \\
\hline 10 & $\begin{array}{l}\text { Exame fisico } \\
\text { (0) Normal }\end{array}$ & AV1010) \\
\hline 11 & $\begin{array}{l}\text { Atelangectasia } \\
\begin{array}{lll}\text { (0) Năo } & \text { (1) } \operatorname{Sim} & \text { (8) }\end{array}\end{array}$ & BAV1011) \\
\hline 12 & $\begin{array}{l}\text { Icterícia } \\
\begin{array}{lll}\text { (0) Não } & \text { (1) Sim } & \text { (8) Não se aplica }\end{array}\end{array}$ & BAV1012) \\
\hline 13 & $\begin{array}{l}\text { Eritema Palmar } \\
\begin{array}{lll}\text { (0) Não } & \text { (1) Sim }\end{array}\end{array}$ & BAV1013) \\
\hline
\end{tabular}




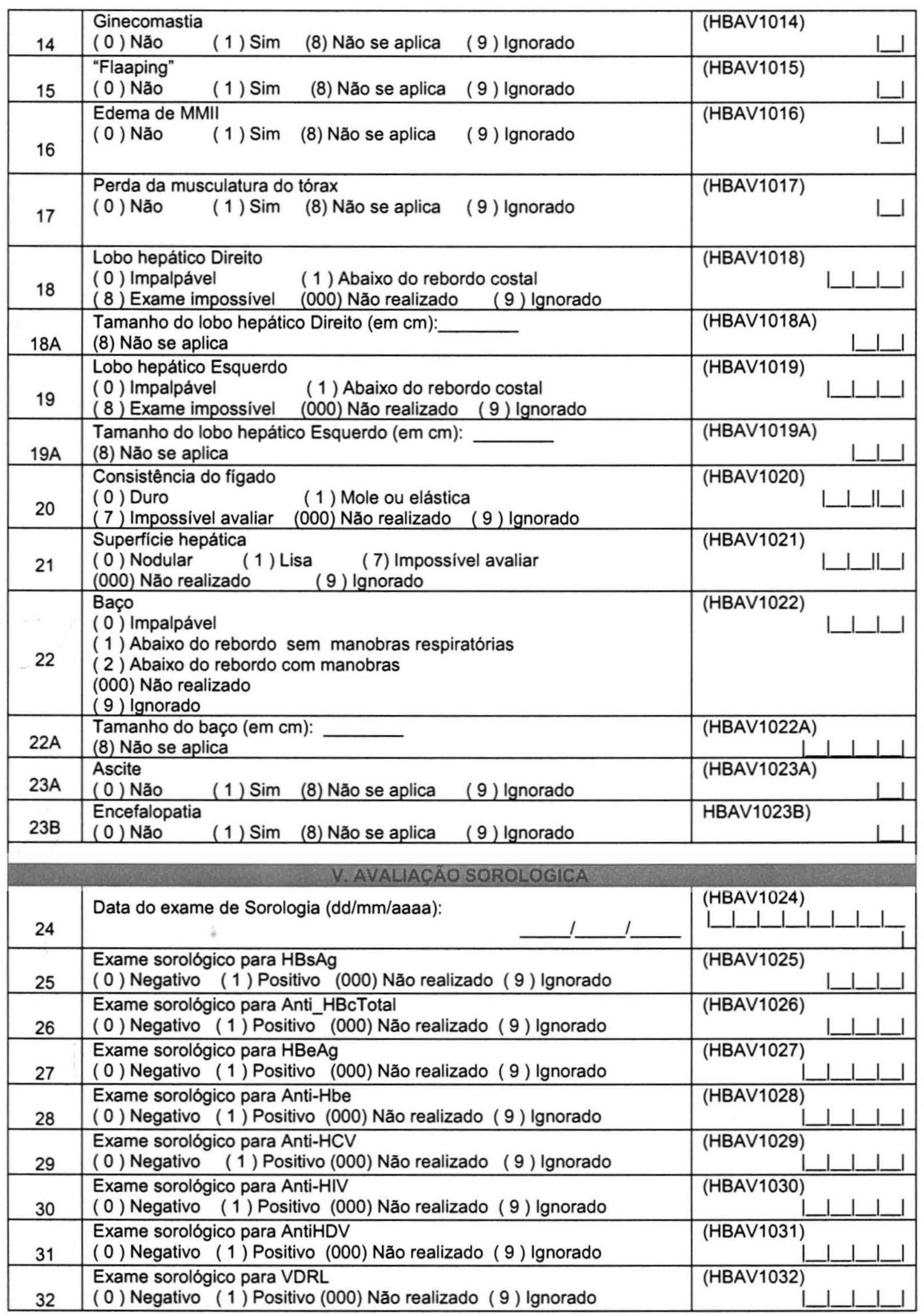




\begin{tabular}{|c|c|c|}
\hline \multicolumn{3}{|c|}{ VI. AVALIAÇĀO LABORATORIAL } \\
\hline 33 & $\begin{array}{l}\text { Data do } 1^{\circ} \text { Hemograma (dd/mm/aaaa): } \\
\text { (000) Não realizado }\end{array}$ & (HBAV1033) \\
\hline $33 \mathrm{~A}$ & $\begin{array}{l}\text { Hemoglobina em g/dl: } \\
\text { (000) Não realizado }\end{array}$ & (HBAV1033A) \\
\hline 33B & $\begin{array}{l}\text { Hematócrito: } \\
\text { (000) Não realizado }\end{array}$ & (HBAV1033B) \\
\hline $33 \mathrm{C}$ & $\begin{array}{l}\text { Leucócitos por } \mathrm{mm}^{3}: \\
\text { (000) Não realizado }\end{array}$ & (HBAV1033C) \\
\hline $33 \mathrm{D}$ & $\begin{array}{l}\text { Segmentados: }(\%) \\
(000) \text { Não realizado }\end{array}$ & (HBAV1033D) \\
\hline 33E & \begin{tabular}{l} 
Bastões: \\
\cline { 2 - 2 }$(000)$ Não realizado
\end{tabular} & (HBAV1033E) \\
\hline $33 \mathrm{~F}$ & $\begin{array}{l}\text { Eosinófilos: } \\
(000) \text { Não realizado }\end{array}$ & (HBAV1033F) \\
\hline $33 G$ & $\begin{array}{l}\text { Linfócitos: } \\
(000) \text { Não realizado }\end{array}$ & 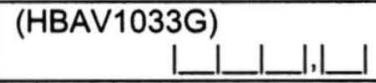 \\
\hline $33 \mathrm{H}$ & $\begin{array}{l}\text { Plaquetas }\left(\mathrm{X} 10^{3}\right) \text { : } \\
(000) \text { Não realizado }\end{array}$ & (HBAV1033H) \\
\hline 331 & $\begin{array}{l}\text { TAP: } \\
(000) \text { Não realizado }\end{array}$ & (HBAV1033I) \\
\hline $33 \mathrm{~J}$ & $\begin{array}{l}\text { INR: } \\
(000) \text { Não realizado } \\
\end{array}$ & (HBAV1033J) \\
\hline 34 & $\begin{array}{l}\text { Data dos primeiros exames Bioquímicos (dd/mm/aaaa): } \\
\text { (000) Não realizado }\end{array}$ & 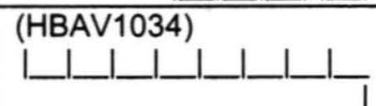 \\
\hline $34 \mathrm{~A}$ & $\begin{array}{l}\text { Transaminases } \\
\text { AST (U/L): } \\
(000) \text { Não realizado }\end{array}$ & 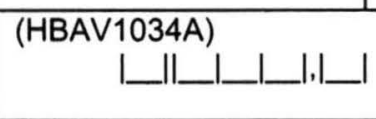 \\
\hline $34 \mathrm{~B}$ & $\begin{array}{l}\text { Transaminases } \\
\text { ALT }(\mathrm{U} / \mathrm{L}) \text { : } \\
(000) \text { Não realizado }\end{array}$ & 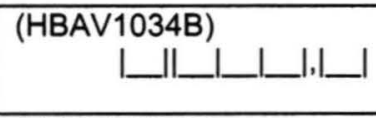 \\
\hline $34 \mathrm{C}$ & $\begin{array}{l}\text { GamaGT (U/I): } \\
(000) \text { Não realizado }\end{array}$ & 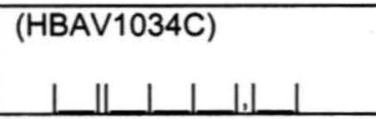 \\
\hline $34 D$ & $\begin{array}{l}\text { Fosfatase Alcalina (U/L): } \\
(000) \text { Não realizado }\end{array}$ & 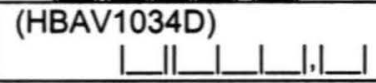 \\
\hline $34 \mathrm{E}$ & $\begin{array}{l}\text { Bilirrubina Total }(\mathrm{mg} / \mathrm{dL}): \\
(000) \text { Não realizado }\end{array}$ & (HBAV1034E) \\
\hline $34 \mathrm{~F}$ & $\begin{array}{l}\text { Bilirrubina Direta(mg/dL): } \\
(000) \text { Não realizado }\end{array}$ & (HBAV1034F) \\
\hline $34 G$ & $\begin{array}{l}\text { Proteinas totais }(\mathrm{g} / \mathrm{dL}): \\
(000) \text { Não realizado }\end{array}$ & 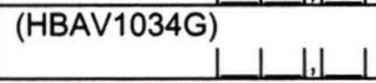 \\
\hline $34 \mathrm{H}$ & $\begin{array}{l}\text { Albumina }(\mathrm{g} / \mathrm{dL}): \\
(000) \text { Não realizado }\end{array}$ & $\begin{array}{r}\text { (HBAV1034H) } \\
\end{array}$ \\
\hline 341 & $\begin{array}{l}\text { Globulina }(\mathrm{g} / \mathrm{dL}): \\
\text { (000) Não realizado }\end{array}$ & (HBAV1034I) \\
\hline $34 \mathrm{~J}$ & $\begin{array}{l}\text { Uréia }(\mathrm{mg} / \mathrm{dL}) \text { : } \\
(000) \text { Não realizado }\end{array}$ & (HBAV1034J) \\
\hline $34 \mathrm{~K}$ & $\begin{array}{l}\text { Creatinina }(\mathrm{mg} / \mathrm{dL}): \\
(000) \text { Não realizado }\end{array}$ & 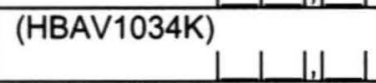 \\
\hline $34 \mathrm{~L}$ & $\begin{array}{l}\text { Glicemia(mg/dL): } \\
\text { (000) Não realizado }\end{array}$ & (HBAV1034L) \\
\hline $34 \mathrm{M}$ & $\begin{array}{l}\text { Alfafetoproteina }(\mathrm{ng} / \mathrm{ml}): \\
(000) \text { Não realizado }\end{array}$ & (HBAV1034M) \\
\hline $34 \mathrm{~N}$ & $\begin{array}{l}\text { Ferritina }(\mathrm{ng} / \mathrm{ml}): \\
(000) \text { Não realizado }\end{array}$ & 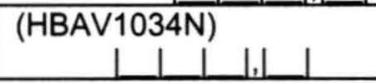 \\
\hline 340 & $\begin{array}{l}\text { Colesterol Total }(\mathrm{mg} / \mathrm{dL}): \\
\text { (000) Não realizado }\end{array}$ & 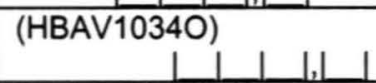 \\
\hline $34 \mathrm{P}$ & $\mathrm{HDL}(\mathrm{mg} / \mathrm{dL}):$ & (HBAV1034P) \\
\hline
\end{tabular}




\begin{tabular}{|c|c|c|}
\hline & (000) Não realizado & $1 \quad 1 \quad 1$ \\
\hline $34 Q$ & $\begin{array}{l}\text { LDL (mg/dL): } \\
\text { (000) Não realizado }\end{array}$ & (HBAV1034Q) \\
\hline $34 \mathrm{R}$ & $\begin{array}{l}\text { Triglicerídeos }(\mathrm{mg} / \mathrm{dL}) \text { : } \\
\text { (000) Não realizado }\end{array}$ & (HBAV1034R) \\
\hline & EXAME DE IMAGEM & \\
\hline 35 & $\begin{array}{l}\text { Data da } 1^{\text {a }} \text {. Ultrassonografia (dd/mm/aaaa): } \\
(000) \text { Não realizado }\end{array}$ & 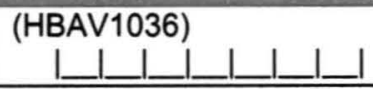 \\
\hline 36 & $\begin{array}{l}\text { Ultrassom normal? } \\
\begin{array}{llll}\text { (0) Não } & \text { (1) Sim } & \text { (8) Não se aplica } & \text { (9) Ignorado }\end{array}\end{array}$ & (HBAV1049) \\
\hline $36 \mathrm{~A}$ & $\begin{array}{l}\text { Se alterada a ultrasom, o paciente apresenta Hepatomegalia? } \\
\begin{array}{llll}\text { (0) Negativo } & (1) \text { Positivo } & (8) \text { Não se aplica } & (9) \text { Ignorado }\end{array}\end{array}$ & (HBAV1036A) \\
\hline $36 \mathrm{~B}$ & $\begin{array}{l}\text { Se alterada a ultrasom, o paciente apresenta Esplenomegalia? } \\
\begin{array}{llll}\text { (0) Negativo } & \text { (1) Positivo } & \text { (8) Não se aplica } & (9) \text { Ignorado }\end{array}\end{array}$ & (HBAV1036B) \\
\hline $36 \mathrm{C}$ & 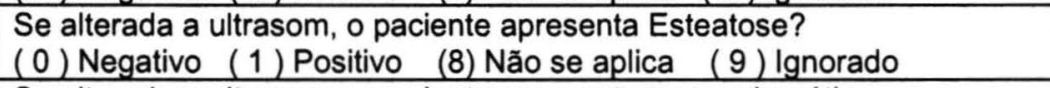 & (HBAV1036C) \\
\hline $36 \mathrm{D}$ & $\begin{array}{l}\text { Se alterada a ultrasom, o paciente apresenta textura hepática } \\
\text { heterogênea? } \\
\begin{array}{llll} & & & \\
\text { (0) Negativo } & \text { (1) Positivo } & \text { (8) Não se aplica } & \text { (9) Ignorado }\end{array}\end{array}$ & (HBAV1036D) \\
\hline $36 \mathrm{E}$ & 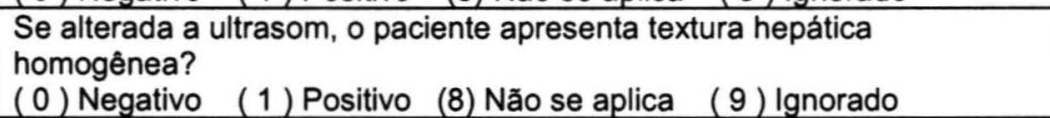 & (HBAV1036E) \\
\hline $36 \mathrm{~F}$ & 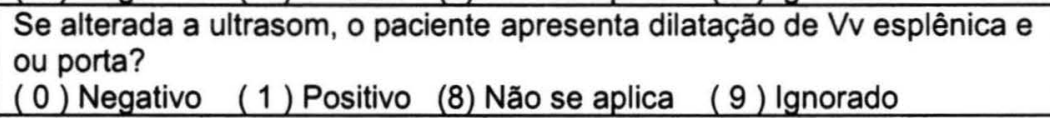 & (HBAV1036F) \\
\hline $36 \mathrm{G}$ & $\begin{array}{l}\text { Se alterada a ultrasom, o paciente apresenta figado diminuido? } \\
\begin{array}{llll}\text { (0) Negativo } & \text { (1) Positivo } & \text { (8) Não se aplica } & \text { (9) Ignorado }\end{array}\end{array}$ & (HBAV1036G) \\
\hline $36 \mathrm{H}$ & $\begin{array}{l}\text { Se alterada a ultrasom, o paciente apresenta nódulo? } \\
\begin{array}{llll}\text { (0) Negativo } & \text { (1) Positivo } & \text { (8) Não se aplica } & \text { (9) Ignorado }\end{array}\end{array}$ & (HBAV1036H) \\
\hline 361 & $\begin{array}{l}\text { Se alterada a ultrasom, o paciente apresenta Ascite? } \\
\begin{array}{llll}\text { (0) Negativo } & \left(\begin{array}{lll}\text { (1) Positivo } & \text { (8) Não se aplica } & (9) \text { Ignorado }\end{array}\right.\end{array}\end{array}$ & (HBAV1036I) \\
\hline $36 \mathrm{~J}$ & $\begin{array}{l}\text { Se alterada a ultrasom, o paciente apresenta outras alterações? } \\
\begin{array}{llll}\text { (0) Negativo } & \left(\begin{array}{lll}\text { (1) Positivo } & \text { (8) Não se aplica } & (9) \text { Ignorado }\end{array}\right.\end{array}\end{array}$ & (HBAV1036J) \\
\hline $36 \mathrm{~K}$ & $\begin{array}{l}\text { Especificar outras alterações } \\
\text { (8) Não se aplica }\end{array}$ & (HBAV1036K) \\
\hline 37 & $\begin{array}{l}\text { Data da } 1^{\mathrm{a}} \text { Endoscopia (dd/mm/aaaa): } \\
\end{array}$ & $\begin{array}{l}\text { (HBAV1037) } \\
\text { |____________ }\end{array}$ \\
\hline $37 \mathrm{~A}$ & $\begin{array}{llll}\text { Endoscopia Normal? } & & & \\
\text { (0) Não } & \text { (1) Sim } & \text { (8) Não se aplica } & \text { (9) Ignorado }\end{array}$ & (HBAV1037A) \\
\hline $37 \mathrm{~B}$ & $\begin{array}{l}\text { Se alterado, apresenta: } \\
\begin{array}{lll}\text { (1) Gastrite enantematosa de Antro } & \text { (2) Pan-gastrite } \\
\text { (3) Gastrite erosiva } & \text { (8) Não se aplica } & \text { (9) Ignorado }\end{array}\end{array}$ & (HBAV1037B) \\
\hline $37 \mathrm{C}$ & 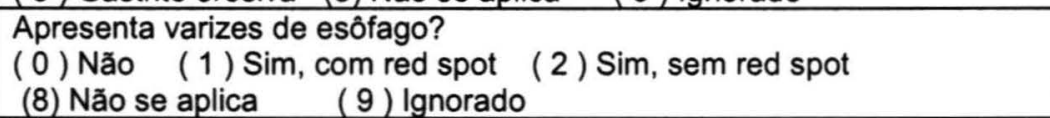 & (HBAV1037C) \\
\hline $37 \mathrm{D}$ & 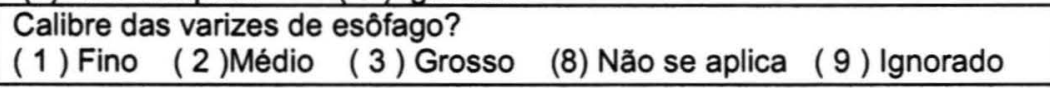 & (HBAV1037D) \\
\hline $37 \mathrm{E}$ & 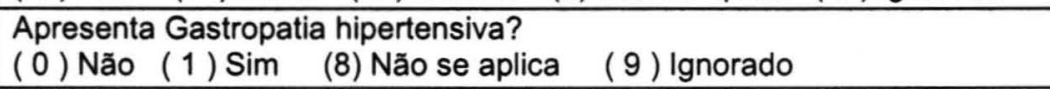 & (HBAV1037E) \\
\hline $37 \mathrm{~F}$ & 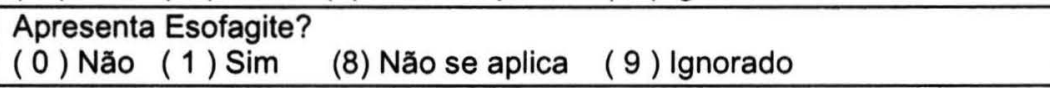 & (HBAV1037F) \\
\hline $37 G$ & $\begin{array}{l}\text { Apresenta outras alterações? } \\
\begin{array}{llll}\text { (0) Não } & (1) \text { Sim } & \text { (8) Não se aplica } & (9) \text { Ignorado }\end{array}\end{array}$ & (HBAV1037G) \\
\hline $37 \mathrm{H}$ & $\begin{array}{l}\text { Se sim na questão anterior, especificar: } \\
\text { (8) Não se aplica }\end{array}$ & (HBAV1037H) \\
\hline 371 & $\begin{array}{l}\text { Apresenta H Pylori positivo } \\
\begin{array}{lll}(0) \text { Não } & (1) \text { Sim } & \text { ( } 9) \text { Ignorado }\end{array}\end{array}$ & (HBAV1050I) \\
\hline
\end{tabular}




\begin{tabular}{|c|c|c|}
\hline 38 & $\begin{array}{l}\text { Realizou tomografia computadorizada de abdômen? } \\
\begin{array}{llll}\text { (0) Não } & \text { (1) Sim } & \text { ( } 9) \text { Ignorado }\end{array}\end{array}$ & (HBAV1038) \\
\hline $38 \mathrm{~A}$ & 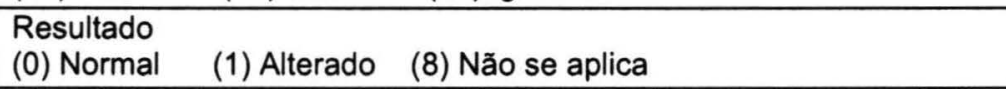 & (HBAV1038A) \\
\hline $38 \mathrm{~B}$ & Descreva: & (HBAV1038B) \\
\hline 39 & $\begin{array}{l}\text { Paciente Co-infectado? } \\
\begin{array}{ll}\text { (0) Não } & \text { (1) Sim }\end{array}\end{array}$ & (HBAV1039) \\
\hline 40 & 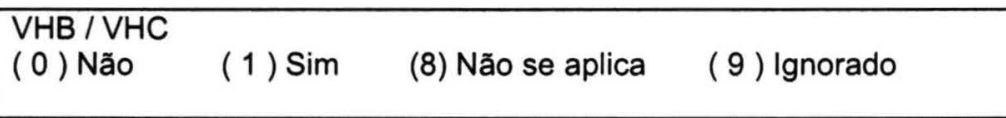 & (HBAV1040) \\
\hline 41 & 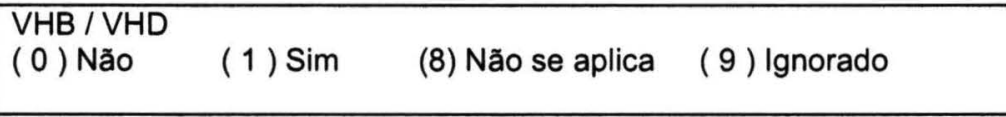 & (HBAV1041) \\
\hline 42 & 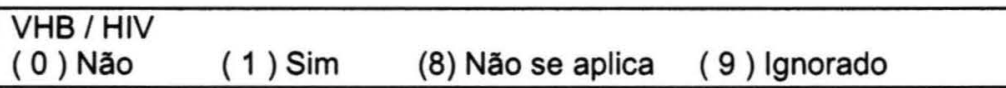 & (HBAV1042) \\
\hline 43 & $\begin{array}{l}\text { VHB/VHC/VHD } \\
\begin{array}{ll}\text { (0) Não } & \text { (1) Sim }\end{array}\end{array}$ & (HBAV1043) \\
\hline 44 & $\begin{array}{l}\text { VHB / VHC / HIV } \\
\begin{array}{llll}\text { (0) Não } & \text { (1) Sim } & \text { (8) Não se aplica } & \text { (9) Ignorado }\end{array}\end{array}$ & (HBAV1044) \\
\hline 45 & $\begin{array}{l}\text { O paciente era portador inativo? } \\
\begin{array}{lll}\text { (0) Não } & \text { (1) Sim } & \text { ( } 9 \text { ) Ignorado }\end{array}\end{array}$ & (HBAV1045) \\
\hline 46 & $\begin{array}{l}\text { O paciente apresentava estado de Imunotolerância? } \\
\begin{array}{llll}\text { (0) Não } & \text { (1) Sim } & \text { (9) Ignorado }\end{array}\end{array}$ & (HBAV1046) \\
\hline 47 & $\begin{array}{l}\text { O paciente apresentava hepatite crônica? } \\
\begin{array}{lll}\text { (0) Não } & (1) \operatorname{Sim} & (9) \text { Ignorado } \\
\end{array}\end{array}$ & (HBAV1047) \\
\hline 48 & $\begin{array}{l}\text { O paciente apresentava cirrose? } \\
\begin{array}{lll}\text { (0) Não } & (1) \text { Sim } & \text { ( } 9) \text { Ignorado }\end{array}\end{array}$ & (HBAV1048) \\
\hline $48 \mathrm{~A}$ & $\begin{array}{l}\text { Em caso de cirrose o paciente apresentava varizes de esôfago? } \\
\begin{array}{llll}\text { (0) Não } & \text { (1) Sim } & \text { (8) Não se aplica } & \text { (9) Ignorado }\end{array}\end{array}$ & (HBAV1048A) \\
\hline $48 \mathrm{~B}$ & $\begin{array}{l}\text { Em caso de cirrose o paciente apresentava Ascite? } \\
\begin{array}{llll}\text { (0) Não } & \text { (1) Sim } & \text { (8) Não se aplica } & \text { (9) Ignorado }\end{array}\end{array}$ & (HBAV1048B) \\
\hline $48 C$ & $\begin{array}{l}\text { Em caso de cirrose o paciente apresentava Peritonite Bacteriana } \\
\text { Espontânea? } \\
\begin{array}{llll}\text { (0) Não } & \text { (1) Sim } & \text { (8) Não se aplica } & \text { (9) Ignorado }\end{array}\end{array}$ & (HBAV1048C) \\
\hline $48 \mathrm{D}$ & $\begin{array}{l}\text { Em caso de cirrose o paciente apresentava Encefalopatia hepática? } \\
\begin{array}{llll}\text { (0) Não } & \text { (1) Sim } & \text { (8) Não se aplica } & \text { (9) Ignorado }\end{array}\end{array}$ & (HBAV1048D) \\
\hline $48 \mathrm{E}$ & $\begin{array}{l}\text { Em caso de cirrose na primeira consulta o paciente apresentava } \\
\text { Hemorragia digestiva? } \\
\begin{array}{llll}\text { (0) Não } & \text { (1) Sim } & \text { (8) Não se aplica } & \text { (9) Ignorado }\end{array}\end{array}$ & (HBAV1048E) \\
\hline $48 \mathrm{~F}$ & $\begin{array}{l}\text { Em caso de cirrose o paciente apresentava Síndrome hepatorrenal? } \\
\begin{array}{llll}\text { (0) Não } & \text { (1) } \mathrm{Sim} & \text { (8) Não se aplica } & \text { (9) Ignorado }\end{array}\end{array}$ & (HBAV1048F) \\
\hline $48 G$ & $\begin{array}{l}\text { Em caso de cirrose qual a classificação no Child } \\
\begin{array}{lllll}\text { (0) Child A } & \text { (1) Child B } & \text { (2) Child C } & \text { (8) Não se aplica (9) Ignorado } \\
\end{array}\end{array}$ & (HBAV1048G) \\
\hline $48 \mathrm{H}$ & $\begin{array}{l}\text { Em caso de cirrose qual o MELD } \\
\begin{array}{llll}\text { (0) Meld até } 10 & \text { (1) Meld de 11a18 } & \text { (2) Meld 19a24 } & \text { (3) Meld maior } \\
\text { que } 25 & \text { (8) Não se aplica (9) Ignorado } & \end{array}\end{array}$ & (HBAV1048H) \\
\hline 49 & $\begin{array}{l}\text { Hepatocarcinoma? } \\
\begin{array}{lll} & \\
\text { (0) Não } & \text { (1) Sim } & \text { (9) Ignorado }\end{array} \\
\end{array}$ & (HBAV1049) \\
\hline $49 \mathrm{~A}$ & $\begin{array}{l}\text { Data do diagnóstico do Hepatocarcinoma (dd/mm/aaaa): } \\
\text { (8) Não se aplica }\end{array}$ & 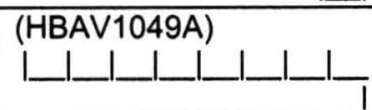 \\
\hline 50 & $\begin{array}{l}\text { Realizou Carga Viral (cópias } / \mathrm{mL} \text { ) } \\
\begin{array}{lll}\text { (0) Não } & \text { (1) Sim } & \text { (9) Ignorado }\end{array}\end{array}$ & (HBAV1050) \\
\hline
\end{tabular}




\begin{tabular}{|c|c|c|}
\hline $50 \mathrm{~A}$ & Resultado do teste de carga viral (cópias $/ \mathrm{mL}$ ): & $\begin{array}{l}(\mathrm{HBAV1050A)} \\
\mid \text { |_I__________ }\end{array}$ \\
\hline $50 \mathrm{~B}$ & $\begin{array}{ll}\text { Data da carga viral (dd/mm/aaaa): } \\
\end{array}$ & (HBAV1050B) \\
\hline 51 & $\begin{array}{l}\text { O genótipo de VHB é conhecido? } \\
\begin{array}{llll}\text { (0) Não } & \text { (1) Sim } & \text { (8) Não se aplica } & \text { (9) Ignorado }\end{array}\end{array}$ & (HBAV1051) \\
\hline $51 \mathrm{~A}$ & $\begin{array}{l}\text { Data da genotipagem (dd/mm/aaaa): } \\
\begin{array}{ll}1 & \text { (8) Não se aplica }\end{array}\end{array}$ & (HBAV1051A) \\
\hline 51B & 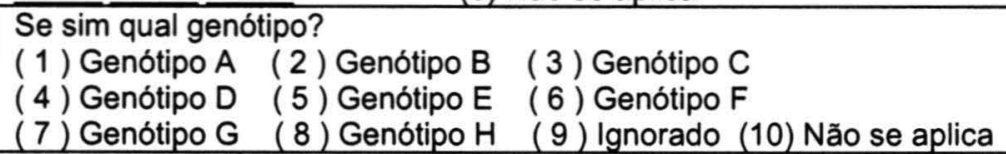 & (HBAV1051B) \\
\hline 52 & $\begin{array}{l}\text { Fez Biópsia Hepática? } \\
\begin{array}{lll}\text { (0) Não } & \text { ( } 1 \text { ) Sim } & \text { (9) Ignorado }\end{array}\end{array}$ & (HBAV1052) \\
\hline $52 \mathrm{~A}$ & $\begin{array}{l}\text { Data da biópsia hepática (dd/mm/aaaa): } \\
\text { (8) Não se aplica }\end{array}$ & (HBAV1052A) \\
\hline $52 \mathrm{~B}$ & 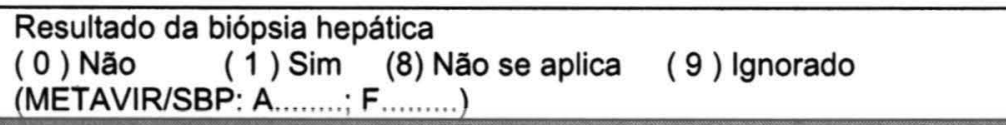 & (HBAV1052B) \\
\hline & XI. INTERCORRENCIA COM O PACIENTE & \\
\hline 53 & $\begin{array}{l}\text { Paciente foi internado? } \\
\begin{array}{lll}\text { (0) Não } & \text { (1) Sim } & \text { ( } 9) \text { Ignorado }\end{array}\end{array}$ & (HBAV1053) \\
\hline $53 \mathrm{~A}$ & $\begin{array}{l}\text { Data da internação (dd/mm/aaaa): } \\
\begin{array}{ll}\text { (8) Não se aplica }\end{array}\end{array}$ & 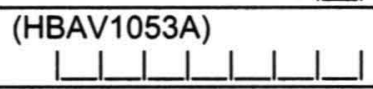 \\
\hline $53 \mathrm{~B}$ & $\begin{array}{l}\text { Motivo da internação - HDA } \\
\begin{array}{llll}\text { (0) Não } & \text { (1) Sim } & \text { (8) Não se aplica } & \text { ( } 9 \text { ) Ignorado }\end{array}\end{array}$ & (HBAV1053B) \\
\hline $53 \mathrm{C}$ & $\begin{array}{l}\text { Motivo da internação - Ascite } \\
\begin{array}{lll}\text { (0) Não } & \text { (1) Sim } & \text { (8) Não se aplica }\end{array}\end{array}$ & (HBAV1053C) \\
\hline $53 \mathrm{D}$ & $\begin{array}{l}\text { Motivo da internação - Encefalopatia } \\
\begin{array}{llll}\text { (0) Não } & \text { (1) Sim } & \text { (8) Não se aplica } & \text { (9) Ignorado }\end{array}\end{array}$ & (HBAV1053D) \\
\hline $53 \mathrm{E}$ & $\begin{array}{l}\text { Motivo da internação - Outro } \\
\begin{array}{lll}\text { (0) Não } & \text { (1) Sim } & \text { (8) Não se aplica }\end{array}\end{array}$ & (HBAV1053E) \\
\hline $53 \mathrm{~F}$ & Se sim na questão anterior, especificar: & (HBAV1053F) \\
\hline 536 & $\begin{array}{l}\text { Tempo de Internação (em dias): } \\
\text { (8) Não se aplica }\end{array}$ & (HBAV1053G) \\
\hline 54 & (1) Sim (9) Ignorado & (HBAV1054) \\
\hline $54 \mathrm{~A}$ & $\begin{array}{ll}\text { Data do óbito (dd/mm/aaaa): } & \text { (8) Não se aplica }\end{array}$ & $\begin{array}{l}(\mathrm{HBAV} 1054 \mathrm{~A}) \\
\text { |_I_I_I_L_L }\end{array}$ \\
\hline & XII. TRATAMENTO & \\
\hline 55 & $\begin{array}{l}\text { Tratamento para VHB? } \\
\begin{array}{lll}\text { ( 0) Não } & \text { (1) Sim } & \text { ( } 9 \text { ) Ignorado }\end{array}\end{array}$ & (HBAV1055) \\
\hline $55 \mathrm{~A}$ & $\begin{array}{l}\text { Data do início do tratamento (dd/mm/aaaa): } \\
\end{array}$ & 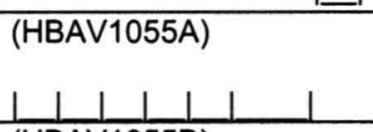 \\
\hline $55 \mathrm{~B}$ & $\begin{array}{l}\text { Medicamento - Interferon } \\
\begin{array}{lll}\text { (0) Não } & \text { (1) Sim } & \text { (8) Não se aplica }\end{array}\end{array}$ & (HBAV1055B) \\
\hline $55 \mathrm{C}$ & $\begin{array}{l}\text { Medicamento - Lamivudina } \\
\begin{array}{lll}\text { (0) Não } & \text { (1) Sim } & \text { (8) Não se aplica }\end{array}\end{array}$ & (HBAV1055C) \\
\hline $55 \mathrm{D}$ & $\begin{array}{l}\text { Medicamento - Entecavir } \\
\begin{array}{lll}\text { (0) Não } & \text { (1) Sim } & \text { (8) Não se aplica }\end{array}\end{array}$ & (HBAV1055D) \\
\hline $55 \mathrm{E}$ & $\begin{array}{l}\text { Medicamento - IFN Peguilado } \\
\begin{array}{lll}\text { (0) Não } & \text { (1) } \mathrm{Sim} & \text { (8) Não se aplica }\end{array}\end{array}$ & (HBAV1055E) \\
\hline $55 \mathrm{~F}$ & $\begin{array}{l}\text { Medicamento - Lamivudina e Adefovir } \\
\begin{array}{lll}\text { (0) Não } & \text { (1) Sim } & \text { (8) Não se aplica }\end{array}\end{array}$ & (HBAV1055F) \\
\hline
\end{tabular}




\begin{tabular}{|c|c|c|}
\hline $55 \mathrm{G}$ & $\begin{array}{l}\text { Medicamento - IFN e LAM } \\
\begin{array}{llll}\text { (0) Não } & \text { (1) Sim } & \text { (8) Não se aplica } & \text { (9) Ignorado }\end{array}\end{array}$ & (HBAV1055G) \\
\hline $55 \mathrm{~F}$ & $\begin{array}{l}\text { Medicamento - IFN Peguilado e Entecavir } \\
\begin{array}{llll}\text { (0) Não } & \text { (1) Sim } & \text { (8) Não se aplica } & \text { ( } 9) \text { Ignorado }\end{array}\end{array}$ & (HBAV1055F) \\
\hline 56 & $\begin{array}{l}\text { Medicação suspensa } \\
\begin{array}{llll}\text { (0) Não } & \text { (1) Sim } & \text { (8) Não se aplica } & \text { ( } 9 \text { ) Ignorado }\end{array}\end{array}$ & (HBAV1056) \\
\hline $56 \mathrm{~A}$ & $\begin{array}{l}\text { Data da suspensão do medicamento (dd/mm/aaaa): } \\
\text { (8) Não se aplica }\end{array}$ & (HBAV1056A) \\
\hline $56 \mathrm{~B}$ & $\begin{array}{l}\text { Motivo da suspensão: Resposta virológica: } \\
\begin{array}{llll}\text { (0) Não } & \text { (1) Sim } & \text { (8) Não se aplica } & \text { ( } 9) \text { Ignorado }\end{array}\end{array}$ & (HBAV1056B) \\
\hline $56 \mathrm{C}$ & $\begin{array}{l}\text { Motivo da suspensão: Resposta Bioquímica: } \\
\begin{array}{llll}\text { (0) Não } & \text { (1) } \mathrm{Sim} & \text { (8) Não se aplica } & \text { ( } 9 \text { ) Ignorado }\end{array}\end{array}$ & (HBAV1056C) \\
\hline $56 \mathrm{D}$ & $\begin{array}{l}\text { Motivo da suspensão: Efeito colateral } \\
\begin{array}{llll}\text { (0) Não } & \text { (1) Sim } & \text { (8) Não se aplica } & \text { (9) Ignorado }\end{array}\end{array}$ & (HBAV1056D) \\
\hline $56 \mathrm{E}$ & $\begin{array}{l}\text { Qual efeito colateral } \\
\text { (8) Não se aplica }\end{array}$ & (HBAV1056E) \\
\hline 01 & Data da segunda consulta (dd/mm/aaaa): & (HBAV2001) \\
\hline 02 & $\begin{array}{l}\text { Apresentou alguma alteração em relação à consulta anterior? } \\
\text { (0) Não ( } 1) \operatorname{Sim}(9) \text { Ignorado }\end{array}$ & (HBAV2002) \\
\hline $02 \mathrm{~A}$ & $\begin{array}{l}\text { Houve mudança no seu diagnóstico clinico em relação à consulta } \\
\text { anterior? (0) Não ( } 1 \text { ) Sim }(9) \text { Ignorado }\end{array}$ & (HBAV2002A) \\
\hline 02B & $\begin{array}{l}\text { Paciente foi internado? } \\
\begin{array}{lll}\text { (0) Não } & \text { ( } 1) \text { Sim } & (9) \text { Ignorado }\end{array}\end{array}$ & (HBAV2002B) \\
\hline $02 \mathrm{C}$ & $\begin{array}{l}\text { Data da internação (dd/mm/aaaa): } \\
\end{array}$ & 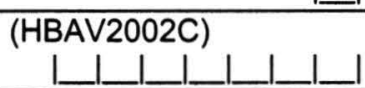 \\
\hline $02 \mathrm{D}$ & $\begin{array}{l}\text { Motivo da internação - HDA } \\
\begin{array}{llll}\text { (0) Não } & \text { (1) Sim } & \text { (8) Não se aplica } & \text { (9) Ignorado }\end{array}\end{array}$ & (HBAV2002D) \\
\hline $02 \mathrm{E}$ & $\begin{array}{l}\text { Motivo da internação - Ascite } \\
\begin{array}{llll}\text { (0) Não } & \text { (1) Sim } & \text { (8) Não se aplica } & \text { ( } 9 \text { ) Ignorado }\end{array}\end{array}$ & (HBAV2002E) \\
\hline $02 \mathrm{~F}$ & $\begin{array}{l}\text { Motivo da internação - Encefalopatia } \\
\begin{array}{llll}\text { (0) Não } & \text { (1) Sim } & \text { (8) Não se aplica } & \text { ( } 9) \text { Ignorado }\end{array}\end{array}$ & (HBAV2002F) \\
\hline $02 \mathrm{G}$ & $\begin{array}{l}\text { Motivo da internação - Outro } \\
\begin{array}{lll}\text { (0) Não } & \text { (1) Sim } & \text { (8) Não se aplica }\end{array}\end{array}$ & (HBAV2002G) \\
\hline $02 \mathrm{H}$ & $\begin{array}{l}\text { Se sim na questão anterior, especificar: } \\
\text { (8) Não se aplica }\end{array}$ & (HBAV2002H) \\
\hline 021 & $\begin{array}{l}\text { Tempo de Internação (em dias): } \\
\text { (8) Não se aplica }\end{array}$ & (HBAV2002I) \\
\hline 03 & $\begin{array}{l}\text { Obito? } \\
\begin{array}{lll}\text { (0) Não } & \text { (1) } \operatorname{Sim} & \text { (9) Ignorado }\end{array}\end{array}$ & (HBAV2003) \\
\hline 03A & $\begin{array}{lll}\text { Data do óbito (dd/mm/aaaa): } & \text { (8) Não se as }\end{array}$ & (HBAV2003A) \\
\hline & II. EXAME FISICO & \\
\hline 04 & $\begin{array}{l}\text { Data do exame (dd/mm/aaaa): } \\
\text { (000) Não realizado }\end{array}$ & 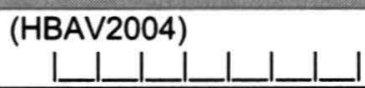 \\
\hline 04A & $\begin{array}{l}\text { Exame físico } \\
\begin{array}{ll} \\
\text { (0) Normal }\end{array}\end{array}$ & (HBAV2004A) \\
\hline 04B & $\begin{array}{l}\text { Atelangectasia } \\
\begin{array}{lll} \\
\text { (0) Não } & \text { (1) Sim } & \text { (8) Não se aplica }\end{array}\end{array}$ & (HBAV2004B) \\
\hline $04 \mathrm{C}$ & 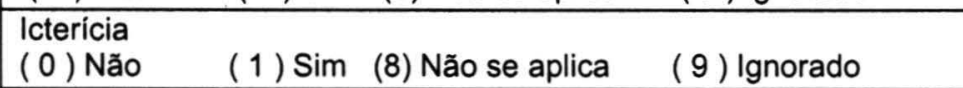 & (HBAV2004C) \\
\hline 04D & $\begin{array}{l}\text { Eritema Palmar } \\
\begin{array}{llll}\text { (0) Não } & \text { (1) Sim } & \text { (8) Não se aplica } & \text { ( } 9 \text { ) Ignorado }\end{array}\end{array}$ & (HBAV2004D) \\
\hline
\end{tabular}




\begin{tabular}{|c|c|c|}
\hline $04 \mathrm{E}$ & $\begin{array}{l}\text { Ginecomastia } \\
\begin{array}{ll}\text { (0) Não } & \text { (1) Sim }\end{array}\end{array}$ & (HBAV2004E) \\
\hline $04 \mathrm{~F}$ & $\begin{array}{lll}\text { (1) Sim (8) Não se aplica (9) Ignorado } & \text { (9) }\end{array}$ & (HBAV2004F) \\
\hline $04 G$ & $\begin{array}{l}\text { Edema de MMII } \\
\begin{array}{llll}\text { (0) Não } & \text { (1) Sim } & \text { (8) Não se aplica } & \text { (9) Ignorado }\end{array}\end{array}$ & (HBAV2004G) \\
\hline 05 & $\begin{array}{l}\text { Perda da musculatura do tórax } \\
\begin{array}{llll}\text { (0) Não } & \text { (1) Sim } & \text { (8) Não se aplica } & \text { (9) Ignorado }\end{array}\end{array}$ & (HBAV2005) \\
\hline 06 & 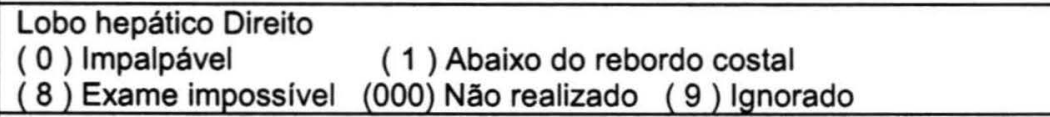 & 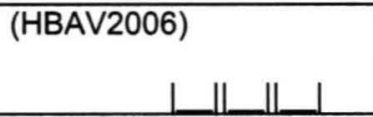 \\
\hline $06 \mathrm{~A}$ & $\begin{array}{l}\text { Tamanho do lobo hepático Direito }(\mathrm{em} \mathrm{cm}) \text { : } \\
\text { (8) Não se aplica }\end{array}$ & $($ HBAV2006A) \\
\hline 07 & $\begin{array}{l}\text { Lobo hepático Esquerdo } \\
\begin{array}{lll}\text { (0) Impalpável } & (1) \text { Abaixo do rebordo costal } \\
\text { (8) Exame impossivel } & (000) \text { Não realizado } & (9) \text { lgnorado }\end{array}\end{array}$ & (HBAV2007) \\
\hline $07 \mathrm{~A}$ & $\begin{array}{l}\text { Tamanho do lobo hepático Esquerdo }(\mathrm{em} \mathrm{cm}): \\
\text { (8) Não se aplica }\end{array}$ & (HBAV2007A) \\
\hline 08 & $\begin{array}{l}\text { Consistência do figado } \\
\begin{array}{ll}\text { ( } 0) \text { Duro } & \text { ( } 1) \text { Mole ou elástica } \\
\text { (8) Impossivel avaliar } & (000) \text { Não realizado }(9) \text { Ignorado }\end{array}\end{array}$ & $\begin{aligned}(\text { HBAV2008) } & \\
|+|+|+| & \end{aligned}$ \\
\hline 09 & $\begin{array}{l}\text { Superficie hepática } \\
\begin{array}{llll}\text { (0) Nodular } & \text { ( } 1) \text { Lisa } & \text { ( } 8) \text { Impossivel avaliar } \\
(000) \text { Não realizado } & (9) \text { Ignorado }\end{array}\end{array}$ & (HBAV2009) \\
\hline 10 & $\begin{array}{l}\text { Baço } \\
\text { (0) Impalpável } \\
\text { (1) Abaixo do rebordo sem manobras respiratórias } \\
\text { (2) Abaixo do rebordo com manobras } \\
\text { (000) Não realizado } \\
\text { (9) Ignorado }\end{array}$ & (HBAV2010) \\
\hline $10 \mathrm{~A}$ & $\begin{array}{l}\text { Tamanho do baço }(\mathrm{em} \mathrm{cm):} \\
\text { (8)Não se aplica }\end{array}$ & (HBAV2010A) \\
\hline 11 & $\begin{array}{l}\text { Ascite } \\
\begin{array}{lll}\text { (0) Não } & \text { (1) Sim } & \text { (8) Não se aplica } \\
\text { (9) Ignorado }\end{array}\end{array}$ & (HBAV2011) \\
\hline 12 & 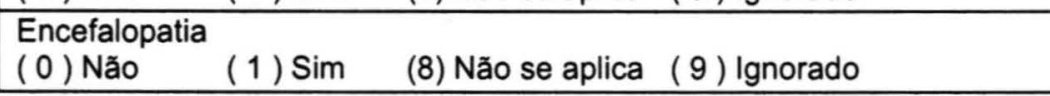 & (HBAV2012) \\
\hline 13 & $\begin{array}{l}\text { Data da } 2^{\mathrm{a}} \text {. Uitrassonografia (dd/mm/aaaa): } \\
\text { (000) Não realizado }\end{array}$ & 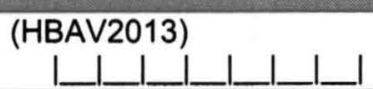 \\
\hline 14 & $\begin{array}{l}\text { Ultrassom normal? } \\
\begin{array}{llll}\text { ( } 0) \text { Não } & (1) \text { Sim } & \text { (8) Não se aplica } & \text { ( } 9 \text { ) Ignorado }\end{array}\end{array}$ & (HBAV2014) \\
\hline $14 \mathrm{~A}$ & $\begin{array}{l}\text { Se alterada a ultrasom, o paciente apresenta Hepatomegalia? } \\
\begin{array}{llll}\text { (0) Negativo } & \text { (1) Positivo } & \text { (8) Não se aplica } & \text { ( } 9) \text { Ignorado }\end{array}\end{array}$ & (HBAV2014A) \\
\hline 14B & 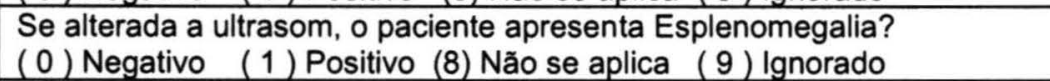 & (HBAV2014B) \\
\hline $14 \mathrm{C}$ & $\begin{array}{l}\text { Se alterada a ultrasom, o paciente apresenta Esteatose? } \\
\begin{array}{llll}\text { (0) Negativo } & \text { (1) Positivo } & \text { (8) Não se aplica } & \text { (9) Ignorado }\end{array}\end{array}$ & (HBAV2014C) \\
\hline $14 \mathrm{D}$ & $\begin{array}{l}\text { Se alterada a ultrasom, o paciente apresenta textura hepática } \\
\text { heterogênea? } \\
\begin{array}{llll} & & \\
\text { (0) Negativo } & \text { (1) Positivo } & (8) \text { Não se aplica } & (9) \text { lgnorado }\end{array}\end{array}$ & (HBAV2014D) \\
\hline $14 \mathrm{E}$ & $\begin{array}{l}\text { Se alterada a ultrasom, o paciente apresenta textura hepática } \\
\text { homogênea? } \\
\begin{array}{llll} & & \\
(0) \text { Negativo } & (1) \text { Positivo } & (8) \text { Não se aplica } & (9) \text { Ignorado }\end{array}\end{array}$ & (HBAV2014E) \\
\hline $14 \mathrm{~F}$ & 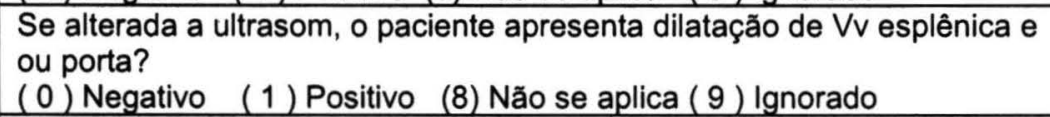 & (HBAV2014F) \\
\hline $14 \mathrm{G}$ & $\begin{array}{l}\text { Se alterada a ultrasom, o paciente apresenta fígado diminuido? } \\
\text { (0) Negativo (1) Positivo (8) Năo se aplica (9) Ignorado }\end{array}$ & (HBAV2014G) \\
\hline
\end{tabular}




\begin{tabular}{|c|c|c|}
\hline $14 \mathrm{H}$ & $\begin{array}{l}\text { Se alterada a ultrasom, o paciente apresenta nódulo? } \\
\text { (0) Negativo (1) Positivo (8) Não se aplica ( } 9 \text { ) lanorado }\end{array}$ & (HBAV2014H) \\
\hline 141 & $\begin{array}{l}\text { Se alterada a ultrasom, o paciente apresenta Ascite? } \\
\begin{array}{llll}\text { (0) Negativo } & \text { (1) Positivo } & \text { (8) Năo se aplica } & (9) \text { Ignorado }\end{array}\end{array}$ & (HBAV2014I) \\
\hline $14 \mathrm{~J}$ & $\begin{array}{l}\text { Se alterada a ultrasom, o paciente apresenta outras alterações? } \\
\text { (0) Negativo (1) Positivo }(8) \text { Não se aplica }(9) \text { Ignorado }\end{array}$ & (HBAV2014J) \\
\hline $14 \mathrm{~K}$ & $\begin{array}{l}\text { Especificar outras alterações } \\
\text { (8) Não se aplica }\end{array}$ & (HBAV2014K) \\
\hline 15 & $\begin{array}{l}\text { Data da } 2^{\mathrm{a}} \text { Endoscopia (dd/mm/aaaa): } \\
\text { (000) Não realizada }\end{array}$ & 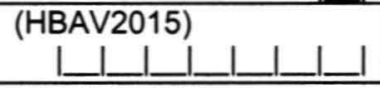 \\
\hline $15 \mathrm{~A}$ & $\begin{array}{l}\text { Endoscopia Normal? } \\
\begin{array}{llll}\text { (0) Não } & (1) \operatorname{Sim} & \text { (8) Não se aplica }(9) \text { lgnorado }\end{array}\end{array}$ & (HBAV2015A) \\
\hline 15B & $\begin{array}{l}\text { Se alterado, apresenta: } \\
\begin{array}{llll}\text { (1) Gastrite enantematosa de Antro } & \text { (2) Pan-gastrite } \\
\text { (3) Gastrite erosiva } & \text { (8) Não se aplica } & \text { (9) lgnorado }\end{array}\end{array}$ & (HBAV2015B) \\
\hline $15 \mathrm{C}$ & 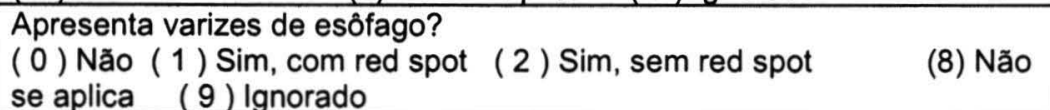 & (HBAV2015C) \\
\hline 15D & $\begin{array}{l}\text { Apresenta Gastropatia hipertensiva? } \\
\begin{array}{ll}\text { (0) Não ( } 1 \text { ) Sim (8) Não se aplica ( } 9 \text { ) Ignorado }\end{array}\end{array}$ & (HBAV2015D) \\
\hline $15 \mathrm{E}$ & $\begin{array}{l}\text { Apresenta Esofagite? } \\
\text { (0) Não ( 1 ) Sim (8) Não se aplica ( } 9 \text { ) Ignorado }\end{array}$ & (HBAV2015E) \\
\hline $15 \mathrm{~F}$ & 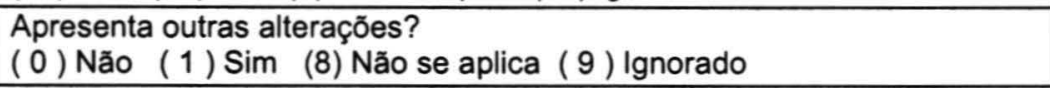 & (HBAV2015F) \\
\hline $15 \mathrm{G}$ & Se sim na questão anterior, especificar: & (HBAV2015G) \\
\hline $15 \mathrm{H}$ & $\begin{array}{l}\text { Apresenta H Pylori positivo } \\
\begin{array}{llll}\text { (0) Não } & \text { (1) Sim } & \text { (8) Não se aplica } & \text { (9) Ignorado }\end{array}\end{array}$ & (HBAV2015H) \\
\hline \multicolumn{3}{|c|}{ IV AVALIAÇÃO LABORATORIAL } \\
\hline 16 & $\begin{array}{l}\text { Data do } 2^{\circ} \text { Hemograma (dd/mm/aaaa): } \\
\text { (000) Não realizado }\end{array}$ & 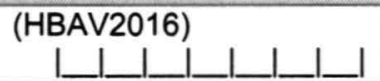 \\
\hline $16 \mathrm{~A}$ & $\begin{array}{l}\text { Hemoglobina em g/dl: } \\
\text { (000) Não realizado }\end{array}$ & 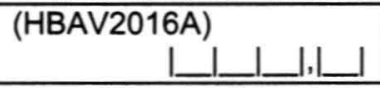 \\
\hline $16 \mathrm{~B}$ & $\begin{array}{l}\text { Hematócrito: } \\
(000) \text { Não realizado }\end{array}$ & 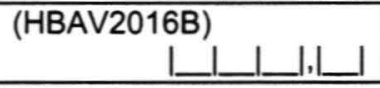 \\
\hline $16 \mathrm{C}$ & $\begin{array}{l}\text { Leucócitos por } \mathrm{mm}^{3}: \\
\text { (000) Não realizado }\end{array}$ & (HBAV2016C) \\
\hline $16 \mathrm{D}$ & $\begin{array}{l}\text { Segmentados: }(\%) \\
\text { (000) Năo realizado }\end{array}$ & (HBAV2016D) \\
\hline $16 \mathrm{E}$ & $\begin{array}{l}\text { Bastões: } \\
\text { (000) Não realizado }\end{array}$ & (HBAV2016E) \\
\hline $16 \mathrm{~F}$ & $\begin{array}{l}\text { Eosinófilos: } \\
(000) \text { Não realizado }\end{array}$ & 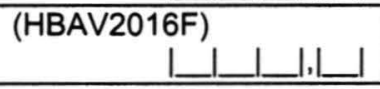 \\
\hline $16 \mathrm{G}$ & $\begin{array}{l}\text { Linfócitos: } \\
(000) \text { Não realizado }\end{array}$ & (HBAV2016G) \\
\hline $16 \mathrm{H}$ & $\begin{array}{l}\text { Plaquetas }\left(X 10^{3}\right) \\
(000) \text { Não realizado }\end{array}$ & (HBAV2016H) \\
\hline 161 & $\begin{array}{l}\text { TAP: } \\
(000) \text { Não realizado }\end{array}$ & (HBAV2016I) \\
\hline $16 \mathrm{~J}$ & $\begin{array}{l}\text { INR: } \\
\text { (000) Não realizado- }\end{array}$ & (HBAV2016J) \\
\hline 17 & $\begin{array}{l}\text { Data dos exames Bioquímicos (dd/mm/aaaa): } \\
\text { (000) Não realizado }\end{array}$ & 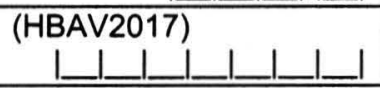 \\
\hline $17 \mathrm{~A}$ & $\begin{array}{ll}\text { Transaminases } & \\
\text { AST (U/L): } & \text { (000) Não real }\end{array}$ & (HBAV2017A) \\
\hline 17B & $\begin{array}{l}\text { Transaminases } \\
\text { ALT }(\mathrm{U} / \mathrm{L}):\end{array}$ & 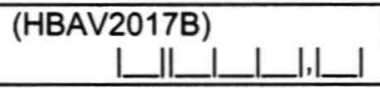 \\
\hline
\end{tabular}




\begin{tabular}{|c|c|c|}
\hline $17 \mathrm{C}$ & GamaGT (U/L): _ & 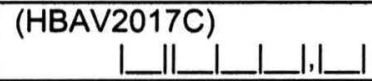 \\
\hline 17D & Fosfatase Alcalina (U/L): ___ (000) Não realizado & 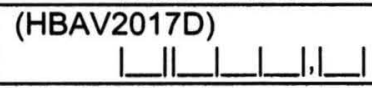 \\
\hline $17 \mathrm{E}$ & Bilirrubina Total (mg/dL): $\quad$ (000) Não realizado & 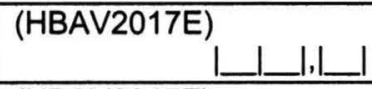 \\
\hline $17 \mathrm{~F}$ & Bilirrubina Direta(mg/dL): _ $\quad$ (000) Não realizado & (HBAV2017F) \\
\hline $17 G$ & Proteinas totais $(\mathrm{g} / \mathrm{dL}): \quad \ldots(000)$ Não realizado & (HBAV2017G) \\
\hline $17 \mathrm{H}$ & - $(000)$ Não realizado & (HBAV2017H) \\
\hline 171 & Globulina $(\mathrm{g} / \mathrm{dL}):{ }_{1} \quad(000)$ Não realizado & (HBAV2017I) \\
\hline $17 \mathrm{~J}$ & Uréia $(\mathrm{mg} / \mathrm{dL}): \quad \ldots(000)$ Não realizado & (HBAV2017J) \\
\hline $17 \mathrm{~K}$ & Creatinina $(\mathrm{mg} / \mathrm{dL}):$ _ & (HBAV2017K) \\
\hline $17 \mathrm{~L}$ & Glicemia(mg/dL): _ـ (000) Não realizado & 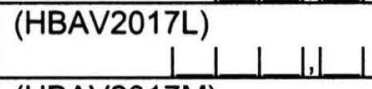 \\
\hline $17 \mathrm{M}$ & ( & 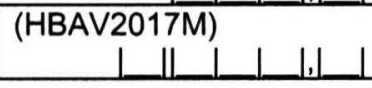 \\
\hline $17 \mathrm{~N}$ & _ (000) Não realizado & 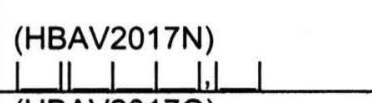 \\
\hline 170 & Colesterol Total $(\mathrm{mg} / \mathrm{dL}):$ _ _ $(000)$ Não realizado & 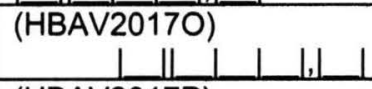 \\
\hline $17 P$ & HDL (mg/dL): — & 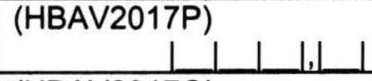 \\
\hline $17 Q$ & LDL $(\mathrm{mg} / \mathrm{dL}):$ _ & 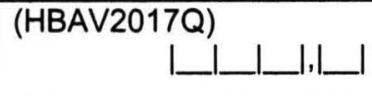 \\
\hline $17 R$ & Triglicerideos $(\mathrm{mg} / \mathrm{dL}):$ _ $\quad(000)$ Não realizado & 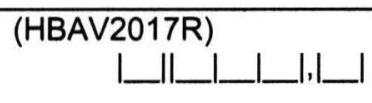 \\
\hline 18 & $\begin{array}{l}\text { O paciente é portador inativo? } \\
\begin{array}{lll}\text { (0) Não } & \text { (1) Sim } & (9) \text { Ignorado }\end{array}\end{array}$ & (HBAV2018) \\
\hline 19 & $\begin{array}{l}\text { O paciente apresenta estado de Imunotolerância? } \\
\begin{array}{lll}\text { (0) Não } & \text { (1) Sim } & \text { (9) Ignorado }\end{array}\end{array}$ & (HBAV2019) \\
\hline 20 & $\begin{array}{l}\text { O paciente apresenta hepatite crônica? } \\
\begin{array}{lll}\text { (0) Não } & \text { (1) Sim } & \text { (9) Ignorado }\end{array}\end{array}$ & (HBAV2020) \\
\hline 21 & $\begin{array}{l}\text { O paciente apresenta cirrose? } \\
\begin{array}{lll}\text { (0) Não } & (1) \text { Sim } & (9) \text { Ignorado }\end{array} \\
\end{array}$ & (HBAV2021) \\
\hline $21 \mathrm{~A}$ & $\begin{array}{l}\text { Em caso de cirrose o paciente apresentava varizes de esôfago? } \\
\begin{array}{llll}\text { (0) Não } & \text { ( } 1) \text { Sim } & \text { (8) Não se aplica } & (9) \text { Ignorado }\end{array}\end{array}$ & (HBAV2021A) \\
\hline 21B & $\begin{array}{l}\text { Em caso de cirrose o paciente apresentava Ascite? } \\
\begin{array}{llll}\text { (0) Não } & \text { (1) Sim } & \text { (8) Não se aplica } & \text { (9) Ignorado }\end{array}\end{array}$ & (HBAV2021B) \\
\hline $21 \mathrm{C}$ & $\begin{array}{l}\text { Em caso de cirrose o paciente apresentava Peritonite Bacteriana } \\
\text { Espontânea? } \\
\begin{array}{llll}\text { (0) Não } & \text { (1) Sim } & \text { (8) Não se aplica } & \text { (9) lgnorado }\end{array}\end{array}$ & (HBAV2021C) \\
\hline 21D & $\begin{array}{l}\text { Em caso de cirrose paciente apresentava Encefalopatia hepática? } \\
\begin{array}{llll}\text { (0) Não } & \text { (1) Sim } & \text { (8) Não se aplica } & \text { (9) Ignorado }\end{array}\end{array}$ & (HBAV2021D) \\
\hline $21 \mathrm{E}$ & $\begin{array}{l}\text { Em caso de cirrose paciente apresentava Hemorragia digestiva? } \\
\begin{array}{llll}\text { (0) Não } & \text { (1) Sim } & \text { (8) Não se aplica } & \text { (9) Ignorado }\end{array}\end{array}$ & (HBAV2021E) \\
\hline $21 \mathrm{~F}$ & $\begin{array}{l}\text { Em caso de cirrose paciente apresentava Sindrome hepatorrenal? } \\
\begin{array}{llll}\text { (0) Não } & \text { (1) Sim } & \text { (8) Não se aplica } & (9) \text { Ignorado }\end{array}\end{array}$ & (HBAV2021F) \\
\hline 22 & $\begin{array}{l}\text { Hepatocarcinoma? } \\
\begin{array}{lll}\text { (0) Não } & \text { (1) Sim } & (9) \text { lgnorado } \\
\end{array}\end{array}$ & (HBAV2022) \\
\hline
\end{tabular}




\begin{tabular}{|c|c|c|}
\hline $22 \Delta$ & $\begin{array}{l}\text { Data do diagnóstico do Hepatocarcinoma (dd/mm/aaaa): } \\
\begin{array}{ll}\text { (8) Não se aplica }\end{array}\end{array}$ & $\begin{array}{l}(\operatorname{HBAV2022A)} \\
1,1,1,1,1,1\end{array}$ \\
\hline 45 & $\begin{array}{l}\text { O paciente era portador inativo? } \\
\begin{array}{lll}\text { (0) Não } & \text { (1) Sim } & \text { (9) Ignorado }\end{array}\end{array}$ & (HBAVF045) \\
\hline 46 & $\begin{array}{l}\text { O paciente apresentava estado de Imunotolerância? } \\
\begin{array}{lll}\text { (0) Não } & \text { (1) Sim } & \text { (9) Ignorado }\end{array}\end{array}$ & (HBAVF046) \\
\hline 47 & $\begin{array}{l}\text { O paciente apresentava hepatite crônica? } \\
\begin{array}{lll}\text { (0) Não } & (1) \operatorname{Sim} & (9) \text { Ignorado }\end{array}\end{array}$ & (HBAVF047) \\
\hline 48 & $\begin{array}{l}\text { O paciente apresentava cirrose? } \\
\begin{array}{lll}\text { (0) Não } & \text { (1) Sim } & (9) \text { Ignorado }\end{array}\end{array}$ & (HBAVF048) \\
\hline $48 \mathrm{~A}$ & $\begin{array}{l}\text { Em caso de cirrose o paciente apresentava varizes de esôfago? } \\
\begin{array}{llll}\text { (0) Não } & \text { (1) Sim } & \text { (8) Não se aplica } & \text { (9) Ignorado }\end{array} \\
\end{array}$ & (HBAVF048A \\
\hline $48 \mathrm{~B}$ & $\begin{array}{l}\text { Em caso de cirrose o paciente apresentava Ascite? } \\
\begin{array}{llll}\text { (0) Não } & \text { (1) Sim } & \text { (8) Não se aplica } & \text { (9) Ignorado }\end{array}\end{array}$ & (HBAVF048B) \\
\hline $48 \mathrm{C}$ & $\begin{array}{l}\text { Em caso de cirrose o paciente apresentava Peritonite Bacteriana } \\
\text { Espontânea? } \\
\begin{array}{llll}\text { (0) Não } & \text { (1) Sim } & \text { (8) Não se aplica } & \text { (9) Ignorado }\end{array}\end{array}$ & (HBAVF048C) \\
\hline $48 \mathrm{D}$ & $\begin{array}{l}\text { Em caso de cirrose o paciente apresentava Encefalopatia hepática? } \\
\begin{array}{llll}\text { (0) Não } & \text { (1) Sim } & \text { (8) Não se aplica } & (9) \text { Ignorado }\end{array}\end{array}$ & (HBAVF048D) \\
\hline $48 \mathrm{E}$ & $\begin{array}{l}\text { Em caso de cirrose na primeira consulta o paciente apresentava } \\
\text { Hemorragia digestiva? } \\
\begin{array}{llll}\text { (0) Não } & \text { (1) Sim } & \text { (8) Não se aplica } & \text { (9) Ignorado }\end{array}\end{array}$ & (HBAVF048E) \\
\hline $48 \mathrm{~F}$ & $\begin{array}{l}\text { Em caso de cirrose o paciente apresentava Sindrome hepatorrenal? } \\
\begin{array}{llll}\text { (0) Não } & \text { (1) Sim } & \text { (8) Não se aplica } & \text { (9) Ignorado }\end{array}\end{array}$ & (HBAVF048F) \\
\hline $48 G$ & $\begin{array}{l}\text { Em caso de cirrose qual a classificação no Child } \\
\begin{array}{llll}\text { (0) Child A } & \text { (1) Child B } & \text { (2) Child C } & \text { (8) Não se aplica (9) Ignorado }\end{array}\end{array}$ & (HBAVF048G) \\
\hline $48 \mathrm{H}$ & $\begin{array}{l}\text { Em caso de cirrose qual o MELD } \\
\begin{array}{llll}\text { (0) Meld até } 10 & \text { (1) Meld de 11a18 } & \text { (2) Meld 19a24 } & \text { (3) Meld maior } \\
\text { que } 25 & \text { (8) Não se aplica (9) Ignorado } & \end{array}\end{array}$ & (HBAVF048H) \\
\hline 49 & $\begin{array}{l}\text { Hepatocarcinoma? } \\
\begin{array}{lll}\text { (0) Não } & (1) \operatorname{Sim} & (9) \text { Ignorado } \\
\end{array}\end{array}$ & (HBAVF049) \\
\hline $49 A$ & $\begin{array}{l}\text { Data do diagnóstico do Hepatocarcinoma (dd/mm/aaaa): } \\
\text { (8) Não se aplica }\end{array}$ & $\begin{array}{l}\text { (HBAVF049A) } \\
\text { |______________ }\end{array}$ \\
\hline
\end{tabular}

A Fé é a certeza das coisas que se esperam e a conviç̧ão das coisas que não se vêem Hebreus 11-1 
Apêndice 3. Características sociodemográficas, na avaliação inicial, dos pacientes com infecção crônica pelo vírus da hepatite $B$ atendidos no Serviço de Assistência Especializada*, 2000 a 2009. Rio Branco, Acre, Brasil.

\begin{tabular}{|c|c|c|c|c|}
\hline & \multicolumn{2}{|c|}{ Classificação clinica } & \multirow[b]{2}{*}{ Total } & \multirow[b]{3}{*}{$\mathbf{P}$} \\
\hline & Hepatite & Cirrose & & \\
\hline & $n-615(91,5 \%)$ & $n-57(8,5)$ & $n-672(100)$ & \\
\hline Características & $\mathbf{N}(\%)$ & $N(\%)$ & & \\
\hline Sexo & & & & 0,003 \\
\hline Masculino & $267(43,4)$ & $36(63,2)$ & $303(45,1)$ & \\
\hline Feminino & $348(56,6)$ & $21(36,8)$ & $369(54,9)$ & \\
\hline \multicolumn{5}{|c|}{ Idade/diagnóstico } \\
\hline Média & $32,5 \pm 12,7)$ & $34,4( \pm 11,6)$ & $32,7( \pm 12,6)$ & \\
\hline Min/Max & 0/72 & $6 / 60$ & $0 / 72$ & \\
\hline \multicolumn{5}{|c|}{ Tempo diagnóstico/meses } \\
\hline $\begin{array}{l}\text { Média } \\
\text { Min/Max }\end{array}$ & $\begin{array}{c}51,2( \pm 39,0) \\
11 / 304\end{array}$ & $\begin{array}{c}68,6( \pm 37,1) \\
12 / 163\end{array}$ & $\begin{array}{c}52,7( \pm 39,1) \\
11 / 304\end{array}$ & \\
\hline \multicolumn{5}{|c|}{ Tempo acompanhamento/meses } \\
\hline Média & $43,3( \pm 29,7)$ & $63,7( \pm 33,6)$ & $45,1( \pm 30,6)$ & \\
\hline Min/Max & $12 / 131$ & $12 / 128$ & $12 / 131$ & \\
\hline \multicolumn{5}{|c|}{ Idade primeira consulta } \\
\hline $\begin{array}{l}\text { Media } \\
\text { Min/Max }\end{array}$ & $\begin{array}{c}33,2( \pm 12,8) \\
1 / 73\end{array}$ & $\begin{array}{c}34,8( \pm 11,8) \\
6 / 62\end{array}$ & $\begin{array}{c}33,3( \pm 12, n) \\
1 / 73\end{array}$ & \\
\hline \multicolumn{5}{|c|}{ Idade na última consulta } \\
\hline Média & $36,8( \pm 12,9)$ & $40,1( \pm 11,9)$ & $37,1(12,8)$ & \\
\hline $\operatorname{Min} / \operatorname{Max}$ & $8 / 74$ & $13 / 70$ & $8 / 74$ & \\
\hline
\end{tabular}


Apêndice 4. Características sociodemográficas, na avaliação inicial dos pacientes com infecção crônica pelo vírus da hepatite $B$ atendidos no Serviço de Assistência Especializada*, 2000 a 2009. Rio Branco, Acre, Brasil.

\begin{tabular}{|c|c|c|c|c|}
\hline \multicolumn{5}{|c|}{ Classificação clínica } \\
\hline & Hepatite & Cirrose & Total & $\mathbf{P}$ \\
\hline & $n-615(91,5 \%)$ & $n-57(8,5)$ & $n-672(100)$ & \\
\hline Características & $\mathbf{N}(\%)$ & $\mathbf{N}(\%)$ & & \\
\hline Profissão & & & & 0,903 \\
\hline Do lar & $158(25,7)$ & $14(24,6)$ & $172(25,6)$ & \\
\hline Agricultor & $72(11,7)$ & $9(15,8)$ & $81(12,1)$ & \\
\hline Estudante & $54(8,8)$ & $2(3,5)$ & $56(8,3)$ & \\
\hline Pedreiro & $37(6,0)$ & $4(7,0)$ & $41(6,1)$ & \\
\hline Funcionário público & $54(8,8)$ & $7(12,3)$ & $61(9,1)$ & \\
\hline Autônomo & $25(4,1)$ & $3(5,3)$ & $28(4,2)$ & \\
\hline Outras profissões & $191(31,0)$ & $16(28,1)$ & $206(30,7)$ & \\
\hline Não trabalha & $25(4,1)$ & $2(3,5)$ & $27(4,0)$ & \\
\hline Estado civil** & & & & 0,310 \\
\hline Casado & $251(42,5)$ & $20(37,0)$ & $271(42,1)$ & \\
\hline Concubinato & $119(20,2)$ & $14(25,9)$ & $133(20,7)$ & \\
\hline Solteiro & $186(31,5)$ & $16(29,6)$ & $202(31,4)$ & \\
\hline Viúvo & $15(2,5)$ & $2(3,7)$ & $17(2,6)$ & \\
\hline Divorciado/separado & $19(3,2)$ & $2(3,7)$ & $21(3,3)$ & \\
\hline Local/nascimento & & & & 0,019 \\
\hline Acre & $482(78,4)$ & $36(63,2)$ & $518(77,1)$ & \\
\hline Amazonas & $99(16,1)$ & $16(28,1)$ & $115(17,1)$ & \\
\hline Outro Estado & $34(5,5)$ & $5(9,1)$ & $39(5,8)$ & \\
\hline Procedência & & & & 0,860 \\
\hline Regional Juruá & $26(4,2)$ & $7(12,3)$ & $33(4,9)$ & \\
\hline Regional Purus & $78(12,7)$ & $3(5,3)$ & $81(12,1)$ & \\
\hline Baixo Acre & $66(10,7)$ & $4(7,0)$ & $70(10,4)$ & \\
\hline Alto Acre & $50(8,1)$ & $7(12,3)$ & $57(8,5)$ & \\
\hline Regional Tarauacá Envira & $23(3,7)$ & $0(0,0)$ & $23(3,4)$ & \\
\hline Rio Branco & $340(55,3)$ & $33(57,9)$ & $373(55,5)$ & \\
\hline Municípios do Amazonas & $32(5,2)$ & $3(5,5)$ & $35(5,2)$ & \\
\hline Cor/raça & & & & 0,119 \\
\hline Pardo & $437(71,1)$ & $38(66,7)$ & $475(70,7)$ & \\
\hline Branco & $125(20,3)$ & $10(17,5)$ & $135(20,1)$ & \\
\hline Negro & $37(6,0)$ & $5(8,8)$ & $42(6,3)$ & \\
\hline Indigena & $16(2,6)$ & $4(7,0)$ & $20(3,0)$ & \\
\hline Amarelo & & & & \\
\hline Escolaridade* & & & & 0,133 \\
\hline$\leq 4$ anos & $193(36,0)$ & $24(44,4)$ & $217(36,8)$ & \\
\hline 5 a 8 anos & $152(28,4)$ & $16(29,6)$ & $168(28,5)$ & \\
\hline 9 anos $a+$ & $191(35,6)$ & $14(25,9)$ & $205(34,7)$ & \\
\hline
\end{tabular}

Total de dados ignorados para a variável *82 pacientes; *^28 pacientes. 
Apêndice 5. Características epidemiológicas dos pacientes com infecção pelo vírus da hepatite $B$ atendidos no Serviço de Assistência Especializada*. 2000 a 2009. Rio Branco, Acre, Brasil.

\begin{tabular}{|c|c|c|c|c|}
\hline \multicolumn{5}{|c|}{ Classificação clínica } \\
\hline & Hepatite & Cirrose & Total & \multirow[b]{2}{*}{$\mathbf{P}$} \\
\hline & $n-615(91,5 \%)$ & $n-57(8,5)$ & $n-672(100)$ & \\
\hline Características & $\mathbf{N}(\%)$ & $\mathbf{N}(\%)$ & & \\
\hline Modo de contagio\# & & & & 0,310 \\
\hline Indeterminado & $131(21,3)$ & $7(12,3)$ & $138(22,8)$ & \\
\hline $\begin{array}{l}\text { Vertical } \\
\text { Ocupacional }\end{array}$ & $\begin{array}{l}4(0,7) \\
5(0,8)\end{array}$ & $\begin{array}{l}0(0,0) \\
0(0,0)\end{array}$ & $\begin{array}{l}4(0,6) \\
5(0,8)\end{array}$ & \\
\hline Sexual & $35(5,7)$ & $5(8,8)$ & $40(6,6)($ & \\
\hline Parenteral & $51(8,3)$ & $4(7,0)$ & $55(9,1)$ & \\
\hline Intra-familiar & $442(71,9)$ & $44(77,2)$ & $486(80,3)$ & \\
\hline Tipo de exposição & & & & \\
\hline Profissional do sexo ${ }^{1}$ & $6(1,0)$ & $0(0,0)$ & $6(0,9)$ & 0,584 \\
\hline Profissional de saúde ${ }^{2}$ & $22(3,7)$ & $2(3,6)$ & $24(3,7)$ & 0,661 \\
\hline Tatuagem $^{3}$ & $52(8,7)$ & $4(7,1)$ & $56(8,5)$ & 0,466 \\
\hline Compartilhou & & & & \\
\hline Objeto cortante ${ }^{4}$ & $413(79,7)$ & $38(70,4)$ & $451(78,8)$ & 0,080 \\
\hline Escova de dente $^{5}$ & $260(50,1)$ & $24(44,4)$ & $284(49,6)$ & 0,259 \\
\hline Transfusão de sangue $^{6}$ & & & & 0,586 \\
\hline Até 10 anos & $29(39,7)$ & $3(42,9)$ & $32(40,0)$ & \\
\hline Mais de 10 anos & $44(60,3)$ & $4(57,1)$ & $48(60,0)$ & \\
\hline Fez cirurgias $^{7}$ & & & & 0,151 \\
\hline Sim, até 10 anos & $117(51,5)$ & $15(65,2)$ & $132(52,8)$ & \\
\hline Sim a mais de 10 anos & $110(48,5)$ & $8(34,8)$ & $118(47,2)$ & \\
\hline Hospitalização & & & & 0,382 \\
\hline Até 10 anos & $106(71,1)$ & $25(75,9)$ & $131(72,0)$ & \\
\hline Mais de 10 anos & $43(28,9)$ & $8(24,2)$ & $51(28,00$ & \\
\hline Tratamento dentário $^{8}$ & $464(89,2)$ & $49(92,5)$ & $513(89,5)$ & 0,325 \\
\hline Endoscopia/vida ${ }^{9}$ & $371(60,7)$ & $51(89,5)$ & $422(63,2)$ & 0,000 \\
\hline Endoscopia/12meses & $227(37,2)$ & $30(52,6)$ & $257(38,5)$ & 0,017 \\
\hline Hemodiálise $^{10}$ & $2(0,3)$ & $1(1,8)$ & $3(0,5)$ & 0,236 \\
\hline
\end{tabular}

Números de pacientes sem informação para as variáveis: \# 67 pacientes (1)17 pacientes; (2)18 pacientes; (3)17 pacientes, (4)100 pacientes; (5)99 pacientes; (6)16 pacientes; (7)42 pacientes, (8)99 pacientes; (9)4 pacientes; (10)17 pacientes 
Apêndice 6. Características epidemiológicas dos pacientes com infecção pelo vírus da hepatite $B$ atendidos no Serviço de Assistência Especializada*. 2000 a 2009. Rio Branco, Acre, Brasil.

\begin{tabular}{|c|c|c|c|c|}
\hline \multicolumn{5}{|c|}{ Classificação clínica } \\
\hline & Hepatite & Cirrose & & \\
\hline & $n-617(91,8 \%)$ & $n-55(8,2)$ & $n-672(100)$ & $\mathbf{P}$ \\
\hline Características & $\mathbf{N}(\%)$ & $\mathbf{N}(\%)$ & & \\
\hline \multicolumn{5}{|l|}{ Tipo de Exposição } \\
\hline Uso seringa de vidro* & $196(38,4)$ & $27(50,9)$ & $223(39,5)$ & 0,052 \\
\hline Droga fumada** & $21(3,7)$ & $4(7,3)$ & $25(4,0)$ & 0,167 \\
\hline Droga inalada*** & $12(2,1)$ & $0(0,0)$ & $12(1,9)$ & 0,331 \\
\hline Droga injetável $\left.\right|^{\star \star \star \star}$ & $4(0,7)$ & $1(1,8)$ & $5(0,8)$ & 0,368 \\
\hline Vacina VHB ${ }^{\star \star \star \star *}$ & $334(66,8)$ & $32(59,3)$ & $366(66,1)$ & 0,168 \\
\hline Doses vacina & & & & 0,146 \\
\hline Não lembra & $15(4,5)$ & $3(9,4)$ & $18(4,9)$ & \\
\hline Uma & $60(18,0)$ & $9(28,1)$ & $69(18,9)$ & \\
\hline Duas & $81(24,3)$ & $4(12,5)$ & $85(23,3)$ & \\
\hline Três & $177(53,2)$ & $16(50,0)$ & $193(52,9)$ & \\
\hline
\end{tabular}

Numero de pacientes sem informação nas variáveis: *108 pacientes; **43 pacientes; ${ }^{* \star *} 42$ pacientes;

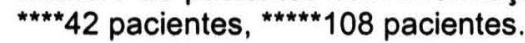


Apêndice 7. Características epidemiológicas dos pacientes com infecção pelo vírus da hepatite $B$ atendidos no Serviço de Assistência Especializada*. 2000 a 2009. Rio Branco, Acre, Brasil

\begin{tabular}{|c|c|c|c|c|}
\hline \multicolumn{5}{|c|}{ Classificação clínica } \\
\hline & Hepatite & Cirrose & Total & \\
\hline & $n-615(91,5 \%)$ & $n-57(8,5)$ & $n-672(100)$ & $\mathbf{P}$ \\
\hline Características & $\mathbf{N}(\%)$ & $N(\%)$ & & \\
\hline \multicolumn{5}{|l|}{ Exposição } \\
\hline Iniciou a vida Sexual & $584(95,0)$ & $55(96,5)$ & $639(95,1)$ & 0,457 \\
\hline Uso de Camisinha* & & & & 0,971 \\
\hline $\begin{array}{l}\text { Não se aplica } \\
\text { Não usa } \\
\text { Usa as vezes } \\
\text { Usa sempre }\end{array}$ & $\begin{array}{c}32(6,2) \\
181(35,3) \\
138(26,9) \\
162(31,6)\end{array}$ & $\begin{array}{c}2(3,7) \\
23(42,6) \\
11(20,4) \\
18(33,3)\end{array}$ & $\begin{array}{c}34(6,00 \\
204(36,0) \\
149(26,3) \\
180(31,7)\end{array}$ & \\
\hline Parceiro atual tem $\mathrm{VHB}^{\star \star}$ & $44(9,5)$ & $6(12,0)$ & $50(9,7)$ & 0,356 \\
\hline $\begin{array}{l}\text { Contato sexual/portador } \\
\text { VHB }\end{array}$ & $38(7,9)$ & $6(11,5)$ & $44(8,3)$ & 0,251 \\
\hline Parceiro teve DST ${ }^{\star \star \star *}$ & $19(4,0)$ & $2(3,9)$ & $21(4,0)$ & 0,673 \\
\hline 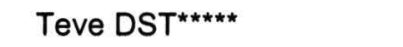 & $35(7,3)$ & $7(13,5)$ & $42(7,9)$ & 0,101 \\
\hline
\end{tabular}


Apêndice 8. Historia de ingestão de álcool dos pacientes com infecção pelo vírus da hepatite $B$ atendidos no Serviço de Assistência Especializada*. 2000 a 2009. Rio Branco, Acre, Brasil.

\begin{tabular}{|c|c|c|c|c|}
\hline \multicolumn{5}{|c|}{ Classificação clínica } \\
\hline & Hepatite & Cirrose & Total & \\
\hline & $n-617(91,8 \%)$ & $n-55(8,2)$ & $n-672(100)$ & $\mathbf{P}$ \\
\hline Características & $\mathrm{N}(\%)$ & $N(\%)$ & & \\
\hline \multicolumn{5}{|l|}{ Exposição } \\
\hline Bebeu na vida* & $293(54,3)$ & $37(68,5)$ & $330(55,6)$ & 0,030 \\
\hline Bebeu 8 drinks no ano & $271(92,5)$ & $34(91,9)$ & $305(92,4)$ & 0,550 \\
\hline Bebeu um drink/30d & $44(15,0)$ & $3(8,1)$ & $47(14,2)$ & 0,191 \\
\hline Freqüência/3meses & & & & 0,103 \\
\hline Nenhuma & $249(85,0)$ & $34(91,9)$ & $283(85,8)$ & \\
\hline Uma vez/mes & $12(4,1)$ & $3(8,1)$ & $15(4,5)$ & \\
\hline Dois a três dia/mês & $9(3,1)$ & $0(0,0)$ & $9(2,7)$ & \\
\hline Um a dois dias/semana & $14(4,8)$ & $0(0,0)$ & $14(4,2)$ & \\
\hline Tres a quatro dia/semana & $6(2,0)$ & $0(0,0)$ & $14(4,2)$ & \\
\hline Quase todos os dias & $1(0,3)$ & $0(0,0)$ & $1(0,3)$ & \\
\hline Todos os dias & $2(0,7)$ & $0(0,0)$ & $2(0,6)$ & \\
\hline Quantos drink/3meses & & & & 0,070 \\
\hline 1 a 5 drink & $12(27,3)$ & $3(100)$ & $15(31,9)$ & \\
\hline 6 a 10 drink & $23(52,3)$ & $0(0,0)$ & $23(48,9)$ & \\
\hline 11 a 15 drink & $6(13,6)$ & $0(0,0)$ & $6(12,8)$ & \\
\hline 16 a 20 drink & $1(2,3)$ & $0(0,0)$ & $1(2,1)$ & \\
\hline Mais de 20 drink & $2(4,5)$ & $0(0,0)$ & $2(4,3)$ & \\
\hline Tratamento álcool & $1(0,3)$ & $0(0,0)$ & $1(0,3)$ & 0,888 \\
\hline Classificação bebida & & & & 0,282 \\
\hline Abstêmio & $247(84,0)$ & $33(89,2)$ & $280(84,6)$ & \\
\hline Bebedor leve & $37(12,5)$ & $4(10,8)$ & $41(12,4)$ & \\
\hline Bebedor pesado & $9(3,1)$ & $0(0,0)$ & $9(2,7)$ & \\
\hline Dependente de álcool & $1(0,3)$ & $0(0,0)$ & $1(0,3)$ & \\
\hline
\end{tabular}




\section{Anexos}

Anexo 1. Glossário de termos técnicos usados na infecção pelo VHB.

\begin{tabular}{|l|l|}
\hline \multicolumn{2}{|c|}{ Definições } \\
\hline Hepatite Crônica B & $\begin{array}{l}\text { Doença necroinflamatória crônica do figado causada pela infecção pelo VHB } \\
\text { com sua persistência por mais de 6 meses. A hepatite B crônica pode ser } \\
\text { subdividida em hepatite crônica HBeAg positico e HBeAg negativo }\end{array}$ \\
\hline $\begin{array}{l}\text { Portador inativo do } \\
\text { HBsAg }\end{array}$ & $\begin{array}{l}\text { Infecção persistente do fígado pelo VHB, sem significante progressão da } \\
\text { doença necroinflamatória }\end{array}$ \\
\hline Hepatite B resolvida & $\begin{array}{l}\text { Infecção previa pelo VHB sem evidencia virológica, bioquímica ou histológica de } \\
\text { infecção ou doença ativa }\end{array}$ \\
\hline $\begin{array}{l}\text { Flare ou exacerbação } \\
\text { aguda da hepatite B }\end{array}$ & $\begin{array}{l}\text { Elevações intermitentes das aminotransferase 10 vezes ou mais o limite normal } \\
\text { ou mais do que duas vezes o valor do baseline }\end{array}$ \\
\hline $\begin{array}{l}\text { Reativação da } \\
\text { hepatite B }\end{array}$ & $\begin{array}{l}\text { Reaparecimento da atividade necroinflamatória do figado na pessoa } \\
\text { sabidamente no estado de portador inativo ou com hepatite B resolvida }\end{array}$ \\
\hline Clearance do HBeag & Perda do HBeAg e na pessoa que era previamente HBeAg positivo \\
\hline $\begin{array}{l}\text { Soroconversão do } \\
\text { HBeAg }\end{array}$ & $\begin{array}{l}\text { Perda do HBeAg e detecção do anti-HBe na pessoa que era previamente } \\
\text { HBeAg positivo e Anti-HBe negativo }\end{array}$ \\
\hline Reversão do HBeAg & $\begin{array}{l}\text { Reaparecimento do HBeAg na pessoa que era previamente HBeAg negativo e } \\
\text { Anti-HBe positivo }\end{array}$ \\
\hline
\end{tabular}

\section{Anexo 2-Critérios diagnósticos para o VHB}

\begin{tabular}{|c|c|}
\hline \multicolumn{2}{|r|}{ Critérios diagnóstico } \\
\hline $\begin{array}{l}\text { Hepatite B } \\
\text { crônica }\end{array}$ & $\begin{array}{l}\text { HBsAg por mais de } 6 \text { meses } \\
\text { HBV-DNA serico -maior } 20.000 \mathrm{Ul} / \mathrm{ml}\left(10^{5} \text { copias } / \mathrm{ml}\right) \text {, valores inferior } 2.000-20.000 \\
\mathrm{Ul} / \mathrm{ml}\left(10^{4}-10^{5} \text { copias } / \mathrm{ml}\right) \text { são frequentemente visto na Hepatite crônica B HBeAg } \\
\text { negativa } \\
\text { Elevações persistente ou intermitente dos niveis de transaminases } \\
\text { Biopsia hepática mostra hepatite crônica com moderada a severa atividade } \\
\text { necroinflamatória }\end{array}$ \\
\hline $\begin{array}{l}\text { Portador Inativo } \\
\text { do HBsAg }\end{array}$ & $\begin{array}{l}\text { HBsAg por mais de } 6 \text { meses } \\
\text { HBeAg negativo, Anti-HBe positivo } \\
\text { VHB-DNA menor que } 2.000 \mathrm{Ul} / \mathrm{ml}\left(10^{4} \text { copias } / \mathrm{ml}\right) \\
\text { Niveis de AST/ALT persistentemente normais } \\
\text { Biopsia hepática com ausência de hepatite significante }\end{array}$ \\
\hline $\begin{array}{l}\text { Hepatite B } \\
\text { resolvida }\end{array}$ & $\begin{array}{l}\text { História previa de hepatite B aguda ou crônica ou presença de Anti-HBc T positivo e } \\
\text { Anti-HBs positivo } \\
\text { HBsAg negativo } \\
\text { VHB-DNA indetectável* } \\
\text { Niveis de ALT normais }\end{array}$ \\
\hline
\end{tabular}

Niveis muito baixos podem ser detectados usando PCR sensiveis

Anexo 3-Perfil sorológico da coinfecção aguda pelos VHB e VHD

\section{Coinfecção}

Perfil tipo 1 (fase precoce de infecção de ambos vírus VHB e VHD):

a) Perfil sorológico do VHB: HBsAg, HBeAg, anti-HBclgM, VHB-DNA

b) Perfil sorológico do VHD:HDAg, antiHDIgG, anti-HDlgM, VHD-RNA

Perfil tipo 2 (fase tardia de infecção por ambos vírus)

a) Perfil sorológico do VHB: HBsAg, antiHBe, anti-HBclgM, VHB-DNA

b) Perfil sorológico do VHD: antiHD IgG, anti-HD IgM, VHD-RNA 
Anexo 4: Perfil sorológico da superinfecção aguda pelo VHD em diferentes padrões sorológicos de portadores do VHB

Superinfecção aguda pelo VHD em portadores do VHB

Perfil tipo 1 (fase inicial de infecção do VHD)

a) Perfil sorológico do VHB: HBsAg, HBeAg ou anti-HBe, anti-HBclgG, VHB-DNA

b) Perfil sorológico do VHD:HDAg, VHD-RNA

Perfil tipo 2 (fase tardia de infecção pelo VHD)

a) Perfil sorológico do VHB: $\mathrm{HBsAg}, \mathrm{HBeAg}$ ou antiHBe, anti-HBclgG, VHB-DNA

b) Perfil sorológico do VHD: antiHD IgG, anti-HD IgM, VHD-RNA

Perfil tipo 3

a) Perfil sorológico do VHB: HBsAg, anti-HBclgG

b) Perfil sorológico do VHD: antiHD IgG, anti-HD IgM, VHD-RNA

Perfil tipo 4 (atípico)

a) Perfil sorológico do VHB: HBsAg indetectável temporariamente*, anti-HBs

b) Perfil sorológico do VHD:HDAg, VHD-RNA

*supressão temporária do HBsAg no soro na superinfecção aguda pelo VHD

Anexo 5. Sistema de graduação de atividade necroinflamatória, fibrose e cirrose

\begin{tabular}{|l|l|l|l|}
\hline Graus & \multicolumn{1}{|c|}{ Atividade Portal/Periportal - A } & \multicolumn{1}{|c|}{ Atividade Lobular } & \multicolumn{1}{c|}{$\begin{array}{c}\text { Fibrose } \\
\text { F }\end{array}$} \\
\hline 0 & Não ou mínima & Não & Não \\
\hline 1 & Inflamação portal (HCP) & Inflamação sem necrose & Espaço porta alargado \\
\hline 2 & $\begin{array}{l}\text { Necrose periférica leve (HCA } \\
\text { leve) }\end{array}$ & $\begin{array}{l}\text { Necrose focal ou corpos } \\
\text { acidófilos }\end{array}$ & $\begin{array}{l}\text { Septos periportais ou } \\
\text { porta-porta com } \\
\text { arquitetura intacta }\end{array}$ \\
\hline 3 & $\begin{array}{l}\text { Necrose periférica moderada } \\
\text { (HCA moderada) }\end{array}$ & Intensa lesão celular focal & $\begin{array}{l}\text { Fibrose com distorção } \\
\text { da arquitetura distorcida } \\
\text { sem cirrose }\end{array}$ \\
\hline 4 & $\begin{array}{l}\text { Necrose periférica intensa (HCA } \\
\text { intensa) }\end{array}$ & Lesão inclui necrose em ponte & $\begin{array}{l}\text { Provável ou cirrose } \\
\text { definida }\end{array}$ \\
\hline
\end{tabular}

Fonte: Scheuer, 1991

Anexo 6: Critérios diagnóstico para HCC - Associação Européia para Estudo de Doença do Figado-ASLD

1. Diagnóstico citohistopatológico ou

2. Lesão arterial hipervascular $>2-\mathrm{cm}$ detecctado por duas técnicas de imagem coincidentes no ajuste de cirrose ou

3. Lesão arterial hipervascular >2-cm detectado por um exame de imagem com nível sérico de AFP

$>400 \mathrm{ng} / \mathrm{mL}$ no ajuste de cirrose 
Anexo 7. População Residente por Faixa Etária e Ano, Período:2000-2009

\begin{tabular}{lcccccccccc}
\hline Faixa Etária & 2000 & 2001 & 2002 & 2003 & 2004 & 2005 & 2006 & 2007 & 2008 & 2009 \\
\hline Menor 1 ano & 15143 & 15593 & 15927 & 16294 & 16656 & 18160 & 18611 & 17418 & 16601 & 16447 \\
1 a 4 anos & 61944 & 63776 & 65150 & 66638 & 68119 & 74333 & 76183 & 70150 & 66812 & 66342 \\
5 a 9 anos & 71287 & 73407 & 74992 & 76710 & 78419 & 85640 & 87770 & 85885 & 82922 & 83410 \\
10 a 14 anos & 68077 & 70117 & 71635 & 73276 & 74926 & 81766 & 83812 & 78782 & 76186 & 77179 \\
15 a 19 anos & 66858 & 68876 & 70375 & 72013 & 73641 & 80339 & 82354 & 74091 & 71074 & 71602 \\
20 a 29 anos & 100954 & 104034 & 106336 & 108834 & 111320 & 121370 & 124462 & 136632 & 130976 & 132275 \\
30 a 39 anos & 68593 & 70707 & 72288 & 74004 & 75709 & 82506 & 84626 & 94194 & 92221 & 95632 \\
40 a 49 anos & 46243 & 47661 & 48726 & 49878 & 51024 & 55515 & 56942 & 63976 & 62395 & 64367 \\
50 a 59 anos & 28023 & 28876 & 29510 & 30206 & 30893 & 33633 & 34487 & 40609 & 40054 & 41674 \\
60 a 69 anos & 16942 & 17454 & 17835 & 18255 & 18666 & 20321 & 20840 & 23448 & 22983 & 23791 \\
70 a 79 anos & 9452 & 9735 & 9951 & 10179 & 10413 & 11345 & 11633 & 12581 & 12244 & 12612 \\
80 anos e mais & 4010 & 4130 & 4220 & 4320 & 4419 & 4809 & 4930 & 5681 & 5605 & 5838 \\
\hline Total & 557526 & 574366 & 586945 & 600607 & 614205 & 669737 & 686650 & 703447 & 680073 & 691169 \\
\hline
\end{tabular}

(FONTE DE DADOS: IBGE, 2009)

Anexo 8. Valores de referencia dos exames bioquímicos realizados no Laboratório Central de Saúde Pública - AC até 2007

\begin{tabular}{lll|l}
\hline \multicolumn{1}{c}{ Enzima } & \multicolumn{1}{c}{ Método } & \multicolumn{1}{c}{ Resultado } & \multicolumn{1}{c}{ Referencia } \\
\hline Fosfatase Alcalina & ROY & U.I & $\begin{array}{l}\text { Adultos-13 a 43 } \\
\text { Crianças até 12 anos- 56 a 156 }\end{array}$ \\
\hline \hline Transaminases & $\begin{array}{l}\text { REITMAN - } \\
\text { FRANKEL }\end{array}$ & UK & $\begin{array}{l}\text { TGO: de 2 a 18 } \\
\text { TGP: de 4 a 20 }\end{array}$ \\
\hline \hline Gama GT & METODO & U.L. & $\begin{array}{l}\text { HOMENS: DE 4 a 26 } \\
\text { MULHERES: DE 4 a 22 }\end{array}$ \\
\hline Bilirrubinas totais e frações & SINS-HORN & $\mathrm{mg} / \mathrm{dl}$ & $\begin{array}{l}\text { BT até 1,2 } \\
\text { BD até 0,4 }\end{array}$ \\
\hline Proteinas totais e frações & Biureto Verde & $\mathrm{g} / \mathrm{dl}$ & $\begin{array}{l}\text { PT- 6,0 a 8,0 } \\
\text { Albumina }-3,5 \text { a 5,5 }\end{array}$ \\
\hline Glicose & Bromo Cresol & 70 a 110 \\
\hline & Enzimático & \\
\hline
\end{tabular}


Anexo 9. Valores de referencia dos exames bioquímicos realizados no Laboratório Central de Saúde Pública - AC em 2008 e 2009.

\begin{tabular}{ll|l|l}
\hline \multicolumn{1}{c|}{ Enzima } & \multicolumn{1}{c|}{ Método } & \multicolumn{1}{c}{ Resultado } & \multicolumn{1}{c}{ Referencia } \\
\hline Fosfatase Alcalina & Dade Behring & U.I. & $\begin{array}{l}\text { Adultos-50 a 126 } \\
\text { Crianças até 12 anos- 75 a 220 }\end{array}$ \\
\hline Transaminases & Dade Behring & UK & TGO: 15 a 37/TGP: 30 a 65 \\
\hline \hline Gama GT & Dade Behring & U/L & 5 a 85 \\
\hline \hline Bilirrubinas totais e frações & Dade Behring & $\mathrm{mg} / \mathrm{dl}$ & BT até 1,0/BD até 0,4 \\
\hline Proteínas totais e frações & Dade Behring & $\mathrm{mg} / \mathrm{dl}$ & PT- 6,4 a 8,2/Albumina - 3,5 a 5,0 \\
\cline { 4 - 5 } & & & \\
\hline Glicose & Dade Behring & $\mathrm{mg} / \mathrm{dl}$ & 70 a 110 \\
\hline & & & \\
\hline
\end{tabular}

Anexo 10. Valores de referencia dos exames bioquímicos realizados no Laboratório Central de Saúde Pública - AC a partir 2010.

\begin{tabular}{l|l|l|l}
\hline \multicolumn{1}{c|}{ Enzima } & \multicolumn{1}{c|}{ Método } & \multicolumn{1}{c}{ Resultado } & \multicolumn{1}{c}{ Referencia } \\
\hline Fosfatase Alcalina & KONELAB 7.1.1 & U/L & 65 a 300 \\
\hline Transaminases & KONELAB 7.1.1 & U/L & TGO: 0 a 32/TGP: 0 a 31 \\
\hline Gama GT & KONELAB 7.1.1 & U/L & 7 a 32 \\
\hline Bilirrubinas totais e frações & KONELAB 7.1.1 & $\mathrm{mg} / \mathrm{dl}$ & $\begin{array}{l}\text { BT 0,0 até 1,3 } \\
\text { BD 0,0 até 0,3 }\end{array}$ \\
\hline Proteinas totais e frações & KONELAB 7.1.1 & $\mathrm{mg} / \mathrm{dl}$ & $\begin{array}{l}\text { PT- } 6,1 \text { a 7,9 } \\
\text { Albumina - 3,5 a 4,8 }\end{array}$ \\
\hline Glicose & KONELAB 7.1.1 & $\mathrm{mg} / \mathrm{dl}$ & 60 a 100 \\
\hline & & & \\
\hline
\end{tabular}


Anexo 11. Algoritmos de tratamento da hepatite B cronica segundo Protocolo Clinico e Diretrizes Terapeuticas para o tratamento da Hepatite Viral Crônica B e Coinfecções, MS(2010).

Algoritmo 1 Individuos virgens de tratamento com $\mathrm{HBeAg}$ reagente, nāo cirróticos

\section{Individuos com HBeAg reagente, não cirróticos}

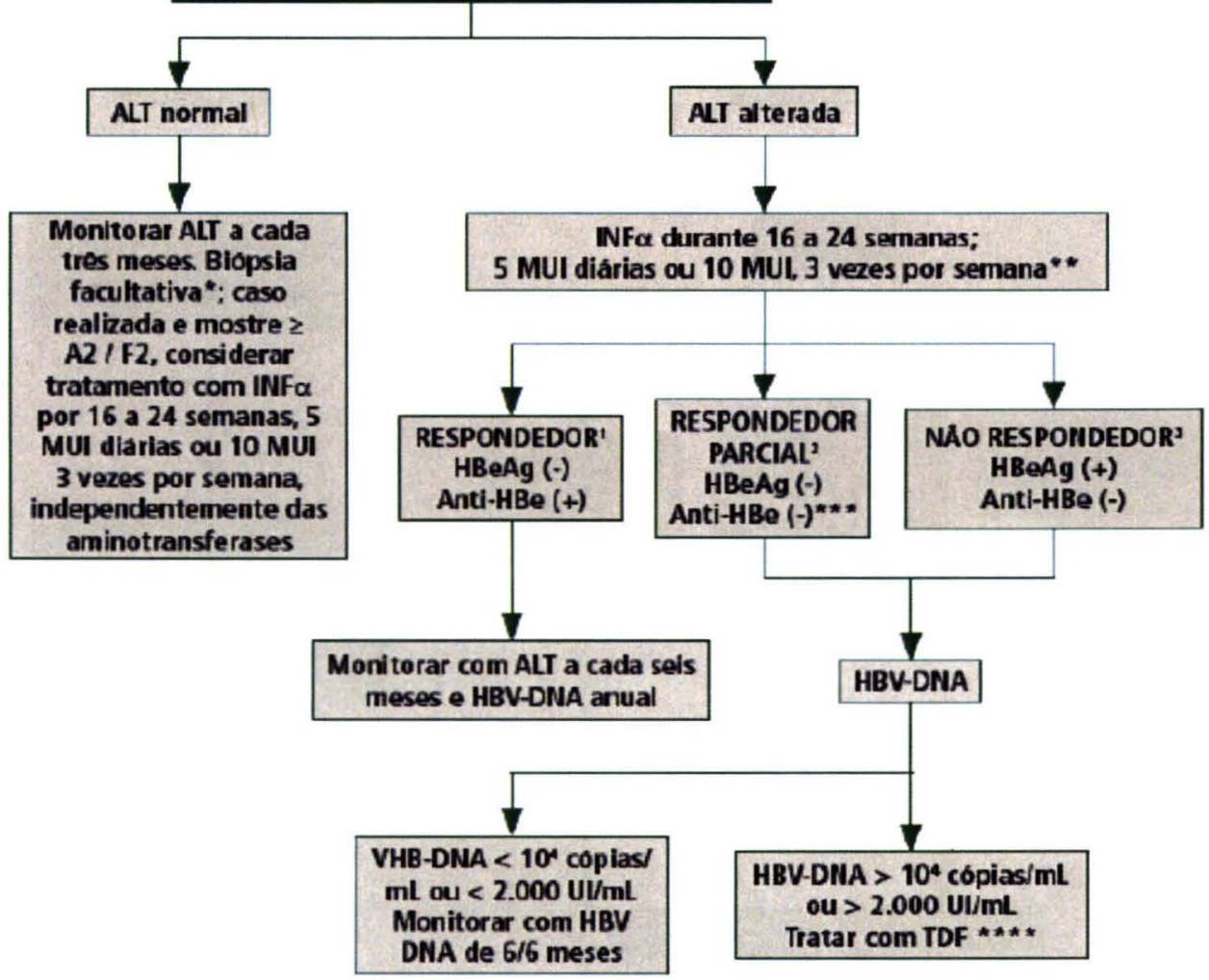

' Respondedor sorológico; 2 Respondedor sorológico parcial; 3 Não respondedor sorológico após 3 meses do término do tratamento.

* Recomenda-se biópsia em individuos com > 40 anos, independentemente das aminotransferases, principalmente se de sexo masculino.

** Recomenda-se estender o tratamento até 24 semanas se o paciente năo apresentar soroconversão em 16 semanas.

^** Se o paciente persistir como HBeAg năo reagente e anti-HBe não reagente, repetir esses exames após três meses do término do tratamento, pois pode haver soroconversāo tardia HBeAglanti-HBe.

${ }^{\star * \star \star} \mathrm{O}$ entecavir pode ser indicado, a critério médico, quando houver restriçōes ao uso do tenofovir. 
Algoritmo .2 Individuos virgens de tratamento, com HBeAg não reagente, não cirróticos

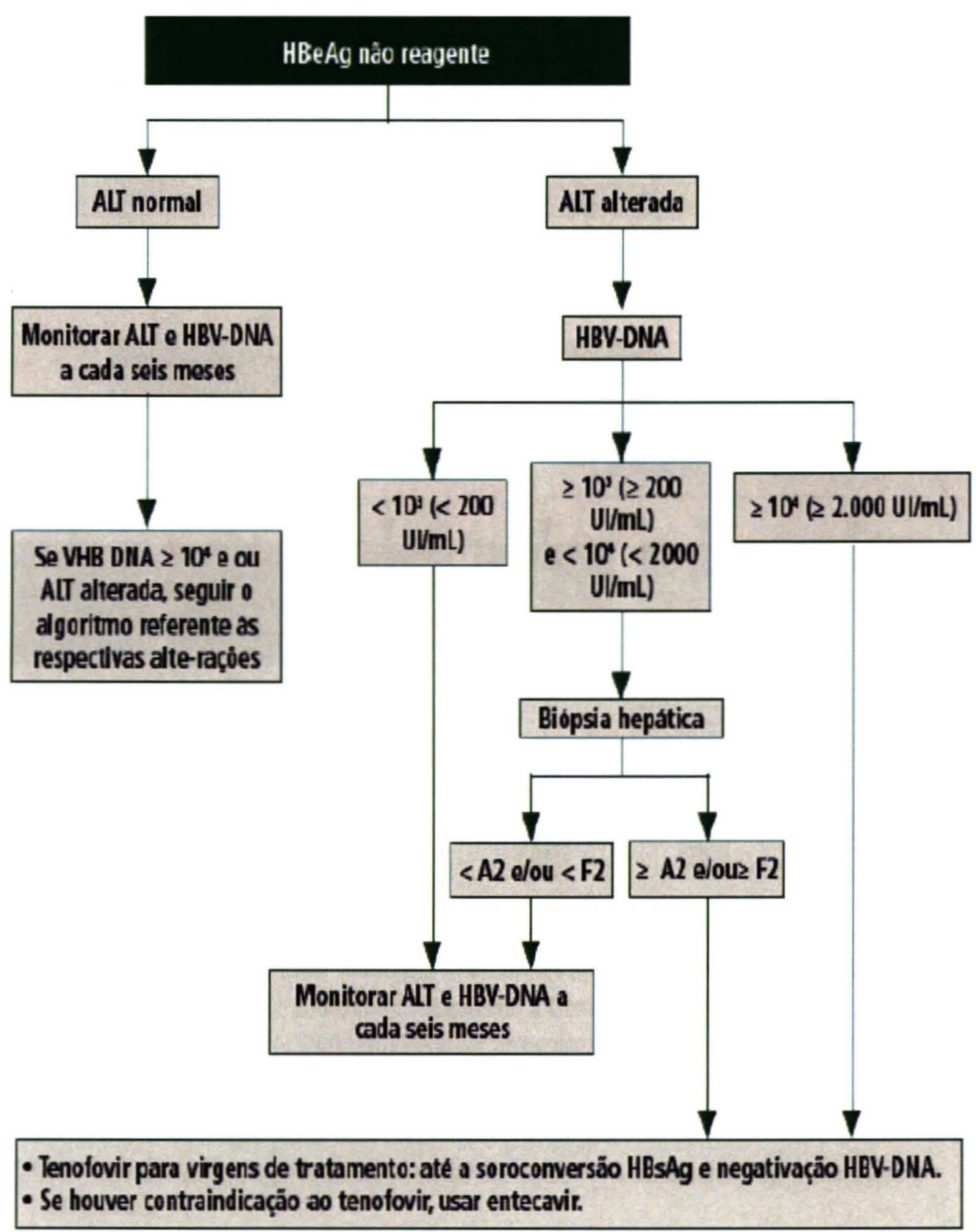


Algoritmo .3 Indivíduos virgens de tratamento, cirróticos, com $\mathrm{HBeAg}$ reagente ou não reagente

\section{Cirroticos HBeAg reagentes ou não reagentes}

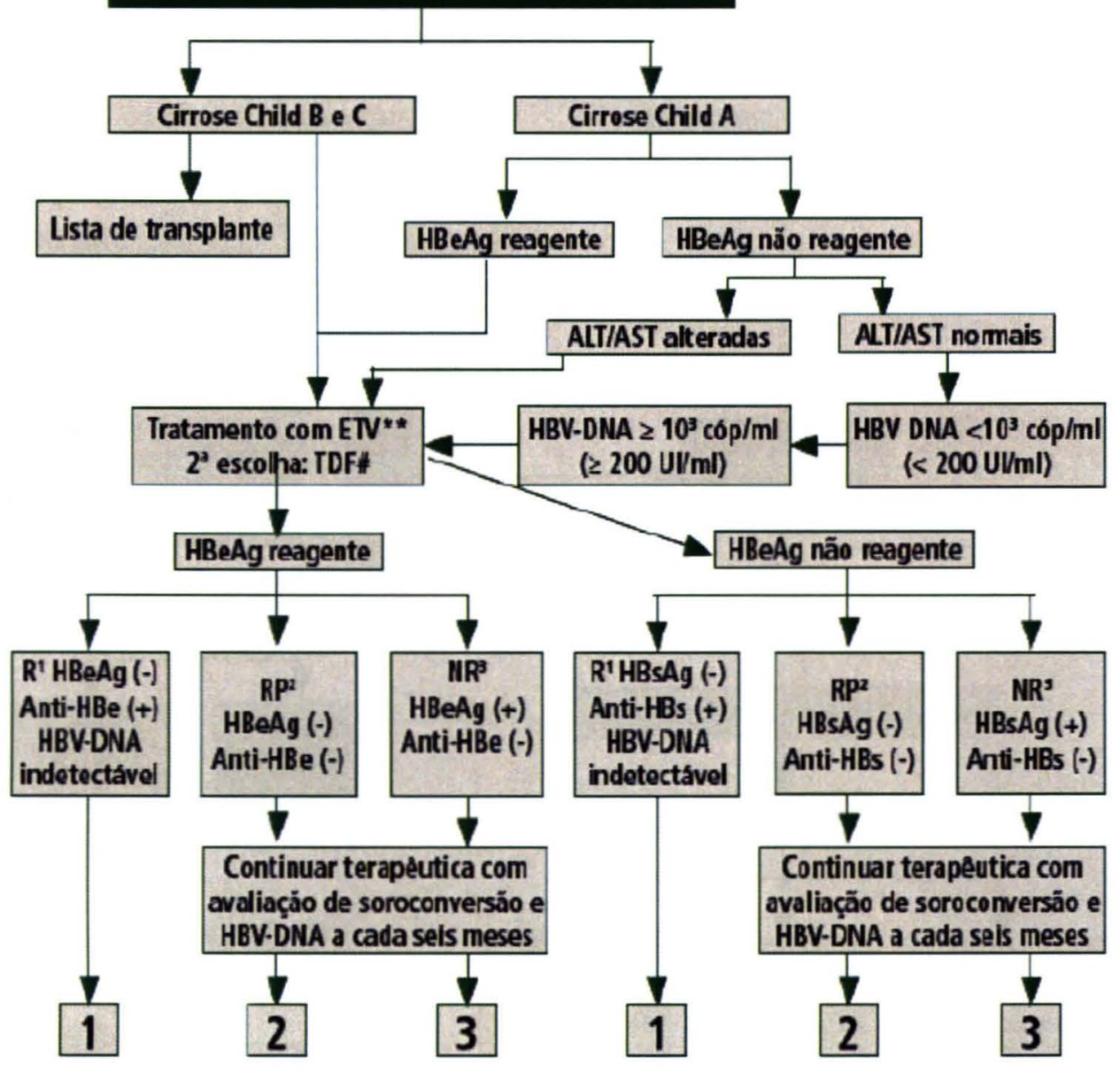

1. Monitorar AST/ALT a cada três meses e HBV-DNA a cada seis meses. Interromper 0 tratamento após a conversão sorológica e seis meses após a negativação do HBV-DNA.

2. HBV-DNA $\geq 10^{3} \mathrm{cóp} / \mathrm{ml}$ ( $\geq 200 \mathrm{Ul} / \mathrm{ml}$ ): Encaminhar à Càmara Técnica de Hepatites.

3. HBV-DNA $<10^{3} \mathrm{cóp} / \mathrm{ml}(<200 \mathrm{UV} / \mathrm{ml})$ :Avaliar soroconversão e HBV-DNA de $6 / 6$ meses.

R1 = Respondedor sorológico; RP2 = Respondedor sorológico parcial; NR3 = Não respondedor sorológico após 12 meses de tratamento.

* Está indicado para virgens de tratamento ou expostos à lamivudina, com resistência confirmada.

** Está indicado havendo impedimento ou contraindicação clínica ao esquema proposto de primeira escolha.

\# Associado à lamivudina ou ao entecavir nos casos de resistência ou como monoterapia, quando do impedimento ou contraindicação clínica ao esquema proposto de primeira ou segunda escolha. 
Algoritmo 4. Individuos com infecção associada com o VHD.

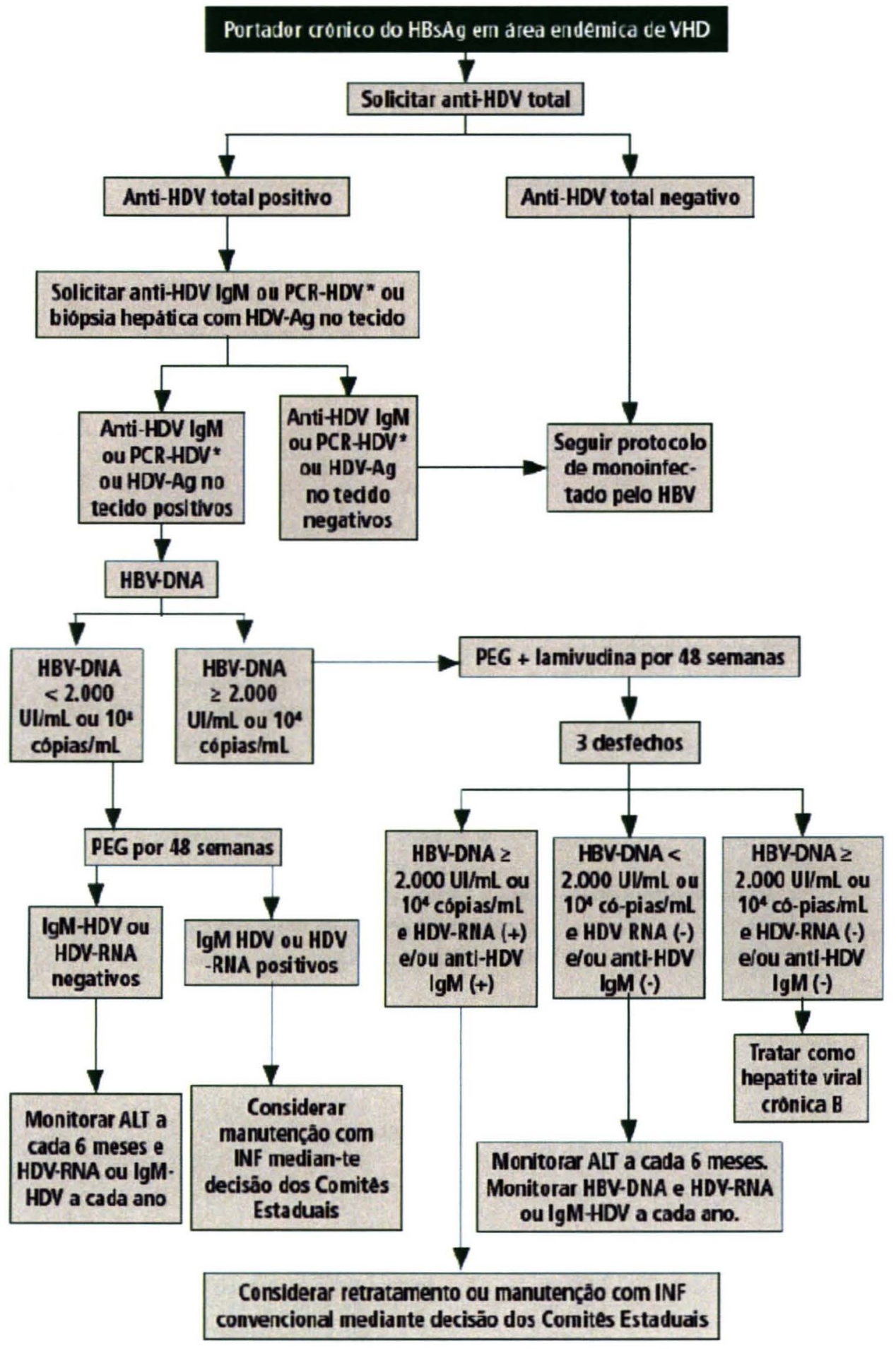

* O PCR-HDV será realizado se disponivel. 


\title{
Anexo 12 - Parecer do Comitê de Ética em Pesquisa COEP/FSP
}

\author{
COMITÊ DE ÉTICA EM PESQUISA - COEP/FSP
Universidade de São Paulo
Faculdade de Saúde Pública \\ Of.COEP/ $270 / 08$ \\ Protocolo \\ Projeto de Pesquisa \\ Pesqulsador(a) \\ 1867 \\ ASPECTOS EPIDEMIOLOGICOS E PROGNÓSTICOS DA HEPATITE B \\ CROONICA NA AMAZÓNIA CENTRAL. \\ Cirley Maria de Oliveira Lobato
}

24 de OUTUBRO de 2008.

Prezado(a) Orientador(a),

- Comitê de Ética em Pesquisa da Faculdade de Saúde Pública da Universidade de Săo Paulo - COEP analisou, em sua 9.\%/08 Sessão ORDINÁRIA, realizada em 17/10/2008, de acordo com os requisitos da Resoluçáo CNS/196/96 e suas complementares, O protocolo de pesquisa acima intitulada e o considerou APROVADO.

Cabe lembrar que conforme Resoluçăo CNS/196/96 são deveres do (a) pesquisador (a): 1 Comunicar, de imediato, qualquer alteração no projeto e aguardar manifestação deste CEP (Comite de Ética em Pesquisa), para dar continuidade à pesquisa;

2. Manter sob sua guarda e em local seguro, pelo prazo de 5 (cinco) anos, os dados da pesquisa, contendo fichas individuais e todos os demais documentos recomendados pelo CEP, no caso eventual auditoria;

3. Comunicar, formalmente a este Comitê, quando do encerramento deste projeto;

4. Elaborar apresentar relatórios parciais e final;

5. Justfificar, perante o CEP, Interrupção do projeto ou a năo publicaçăo dos resultados.

Atenciosamente.

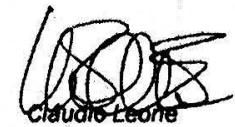

Professor Associado

Coondenador do Comltê de Ética em Pesqulsa - FSP/COEP

IIm. Sr.

Prof. Dr. ELISEU ALVES WALDMAN

DEPARTAMENTO DE EPIDEMIOLOGIA

FACULDADE DE SAÚDE PÚBUICA

UNNERSIDADE DE SAO PAULO

Av. Dr. Arnaldo, 715 - Assessoria Académica - CEP: 01246-904 - Săo Paulo - SP Telefones: (55-11) 3061-7779/7742 e-mail: coep@fsp.usp.br site muw.fsp.usp,br 


\title{
COMITÊ DE ÉTICA EM PESOUISA - CEP
}

\author{
PARECER FINAL $N^{n} 156 / 2008$
}

PROTOCOLO N" 340/2008

Projeto de Pesquisa: “Aspectos Epidemiológicos e Prognóstico da Hepatite B Crònica na Amazònia Ocidental".

Local onde será realizada a pesquisa: Hospital de Urgència e Emergência de Rio Branco - SAE

Pesquisador Responsável: Cirley Maria de Oliveira Lobato.

Data de Apresentação ao CEP 29/09/2008

O projeto atende todas as exigências do CEP, e de acordo com a Res 196/96. este Comitê de Ética em Pesquisa considera o projeto APROVADO

\section{SITUAĊ̃O DO PROJETO: APROVADO}
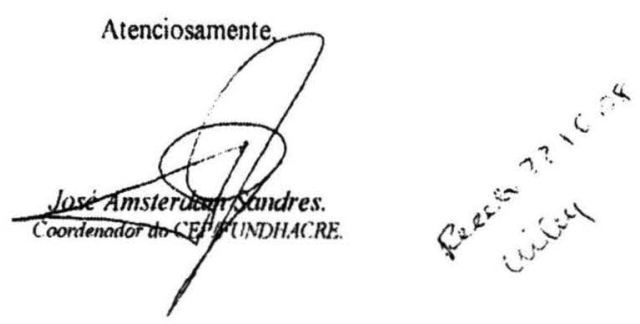
Anexo 14 - Curriculo Lattes

Cirley Maria de Oliveira Lobato

Possui graduação em Medicina pela Universidade do Amazonas-Faculdade de Ciências da Saúde (1990), residência em Medicina Tropical pelo Fundação de Medicina Tropical do Amazonas (1993) e mestrado em Medicina e Saúde pela Universidade Federal da Bahia (2003). Atualmente é professora auxiliar da Universidade do Acre, Faculdade de Medicina e médica infectologista da Secretaria de Saúde do Acre-SESACRE. Doutoranda do programa Saúde Pública, área de concentração Epidemiologia da Universidade de São Paulo. Tem experiência na área de Medicina, com ênfase em DOENÇAS INFECCIOSAS E PARASITÁRIAS, atuando principalmente nos seguintes temas: Acre, epidemiologia, hepatite B, intra-familiar e região Amazônica. Membro da Academia Acriana de Medicina

(Texto informado pelo autor)

Última atualização do currículo em 20/07/2011

Endereço para acessar este CV:

http://lattes.cnpq.br/0256684710388640

Certificado

pelo autor em 


\section{Eliseu Alves Waldman}

\section{Bolsista de Produtividade em Pesquisa do CNPq - Nível 2}

Possui graduação em Medicina pela Pontifícia Universidade Católica de São Paulo (1972), residência médica em Doenças Infecciosas e Parasitárias no Hospital das Clínicas da Faculdade de Medicina da USP (1973-1976); curso de especialização em Medicina Tropical em 1974; curso de especialização em Saúde Pública pela Faculdade de Saúde Pública da Universidade de São Paulo (1975); Especialização em Administração Pública pela Fundação do Desenvolvimento Administrativo, FUNDAP (1978-1980); Curso de Especialização em Vigilância Epidemiológica (1982); mestrado em Doenças Infecciosas e Parasitárias pela Universidade de São Paulo (1982); doutorado em Saúde Pública pela Universidade de São Paulo (1991) e pós-doutorado no Departamento de Epidemiologia da School of Public Health of the Johns Hopkins University, Baltimore, EUA, como bolsista da Fundação de Amparo à Pesquisa do Estado de São Paulo (2001). É professor do Departamento de Epidemiologia da Faculdade de Saúde Pública da Universidade de São Paulo, atuando na graduação e pós-graduação. Participa do corpo editorial de revistas científicas cujo escopo abrange os campos da Saúde Pública, Epidemiologia e Direito Sanitário. Tem experiência na área de Saúde Coletiva, com foco em Epidemiologia, atuando principalmente nos seguintes temas: epidemiologia, vigilância e controle de doenças transmissíveis. (Texto informado pelo autor)

Última atualização do currículo em 23/07/2011

Endereço para acessar este CV:

http://lattes.cnpq.br/8924923035849703 